\title{
LEVANTAMENTO FLORESTAL NA ESTAÇÃO ECOLÓGICA DOS CAETETUS COMO SUBSÍDIOS PARA LAUDOS DE DESAPROPRIAÇÃO AMBIENTAL
}

\author{
FINÊ THOMAZ ROCHA \\ B i ó 1 og o
}

Orientador: Prof. Dr. JOÃo LUÍS FERREIRA BATISTA

Dissertação apresentada à Escola Superior de Agricultura "Luiz de Queiroz", Universidade de São Paulo, para obtenção do Título de Mestre Recursos Florestais, com opção em Conservação de Ecossistemas Florestais.

PIRACICABA

Estado de São Paulo - Brasil

Agosto - 2003 


\title{
Dados Internacionais de Catalogação na Publicação (CIP) DIVISÃo DE BIBLIOTECA E DOCUMENTAÇÃO - ESALQ/USP
}

\author{
Rocha, Finê Thomaz \\ Levantamento florestal na Estação Ecológica dos Caetetus como subsídio para \\ laudos de desapropriação ambiental / Finê Thomaz Rocha. - Piracicaba, 2003. \\ 155 p. : il. \\ Dissertação (mestrado) - Escola Superior de Agricultura Luiz de Queiroz, \\ 2003. \\ Bibliografia. \\ 1. Estação ecológica 2. Desapropriação 3. Fitossociologia 4. Pericia técnica \\ 1. Título
}

CDD 634.9

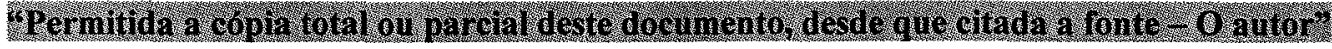

3. do dopolto junto CPQ/ESALG

$0+108 \cdot 2003$ 
À Janice pelo apoio, amor, incentivo, e companhia em todos os momentos.

À nossas filhas Sara e Paula, pela alegria que elas significam e pela compreensão nos meus momentos de ausência. 


\section{AGRADECIMENTOS}

Primeiramente a Deus, pelo dom da vida.

Aos meus pais, Joaquim (in memoriam) e Margarida, pela minha formação;

ao Prof. João Batista, pela orientação e amizade;

ao Baitello, pela identificação das Lauráceas, além das críticas e sugestões;

ao Rubens, pelo apoio e sugestões;

ao Geraldo, pelo apoio na identificação do material botânico;

aos companheiros de trabalho de campo, Beto, Fábio e Sérgio;

ao Osny, pela identificação das Myrtaceae e companhia nas viagens;

ao João Aurélio, pela identificação da Meliaceae e outros materiais botânico;

ao Wilson Contieri, pelo apoio incondicional;

à Nininha e à Valdely, pelas sugestões e críticas no campo jurídico;

ao Jefferson, pela configuração dos dados e elaboração de tabelas;

aos colegas do Laboratório de Métodos Quantitativos;

à Izabel Mattos, pelo apoio na classificação da vegetação;

à equipe que elaborou o Plano de Manejo de Caetetus, por ter cedido esse material tão precioso;

ao Wilian e Elena, ao Bene e Maria José, pelos momentos de descontração e amizade;

ao Samuel, pelo apoio na área da informática e auxilio na elaboração das apresentações;

aos meus sogros, Osíris e Nelson, pela acolhida, almoços e jantares quando eu passava pela cidade de Bauru, na época das viagens de campo;

ao meu irmão Washington, por ter acreditado e fornecido bibliografias jurídicas;

aos Estagiários Fernando e Lucas, pelo auxílio na preparação do material botânico;

ao Ernane, pela ajuda na preparação do material botânico; 
à Sandra e à Gláucia, pela leitura crítica e sug estões visando a melhoria do trabalho; ao Marco Nalon pelo auxílio coma as imagens digitais;

às pessoas que de forma direta ou indireta contribuíram para que mais esta etapa pudesse ser concluída. 


\section{SUMARIO}

Página

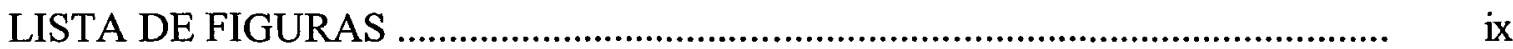

LISTA DE TABELAS ........................................................................................ x xii

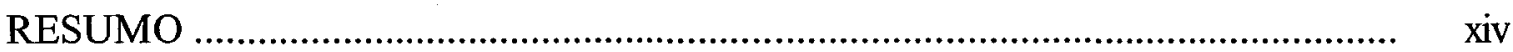

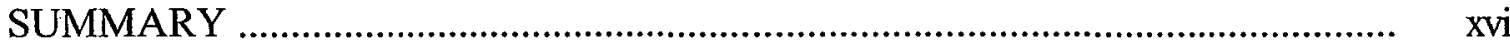

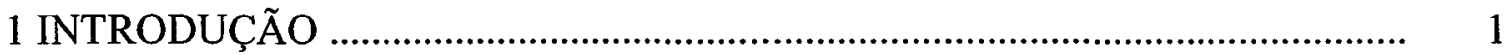

2 REVISÃO DE LITERATURA …................................................................... 7

2.1 Considerações sobre amostragem - base para os levantamentos ......................... 7

2.2 Levantamentos de vegetação ................................................................................

2.2.1 Importância ....................................................................................................

2.2.2 Método de Quadrantes ............................................................................. 10

2.2.3 Método de Parcelas ........................................................................................ 11

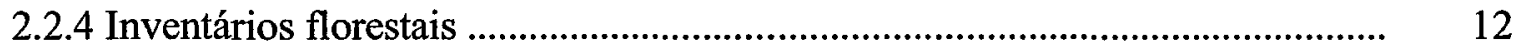

2.3 Comparação de métodos ...................................................................................... 15

2.4 Floresta Estacional Semidecidual .......................................................................... 18

2.5 Trabalhos realizados na Estação Ecológica dos Caetetus ....................................... 20

2.6 A legislação ambiental e o laudo de desapropriação .............................................. 21

2.6 .1 Introdução ................................................................................................... 21

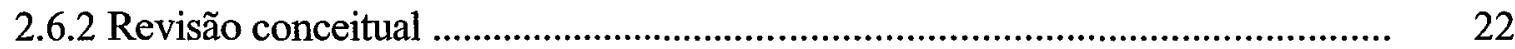

2.6.2.1 Desapropriação .................................................................................................. 22

2.6.2.2 Laudo pericial ......................................................................................... 24 
2.6.2.3 Direitos e restrições ao uso da propriedade florestal ....................................... 26

2.6.2.4 Valoração ambiental ...................................................................................... 27

2.6.2.4.1 Método de Valoração Cotingente ................................................................ 29

2.6.2.4.2 Método Custo de Viagem ......................................................................... 29

2.6.2.4.3 Método de Preços Hedômicos ...................................................................... 30

2.6.2.4.4 Método Dose-Resposta .......................................................................... $\quad 30$

2.6.2.4.5 Método Custo Reposição ................................................................................ 31

2.6.2.4.6 Método de Custos Evitados ................................................................... 31

2.6.3 Legislação Ambiental ................................................................................... 31

2.6.3.1 Código Florestal ................................................................................... 32

2.6.4. Conteúdo do laudo ...................................................................................... 36

3 MATERIAL E MÉTODOS ........................................................................ 37

3.1 Estação Ecológica dos Caetetus - área de estudo ................................................. 37

3.1.1 Localização e histórico ............................................................................... 37

3.1.2 Clima, solo e vegetação ................................................................................. 40

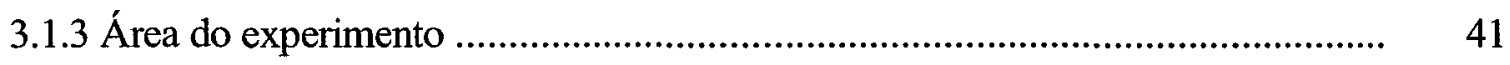

3.2 Métodos de amostragem empregados .................................................................... 43

3.3 Procedimentos de campo ................................................................................. 43

3.3.1 Instalação das parcelas .................................................................................. 43

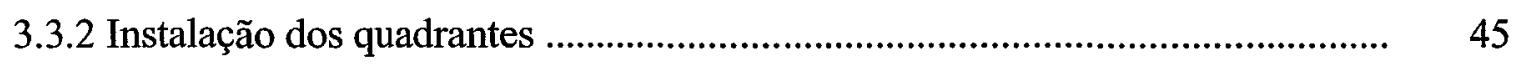

3.4 Grupos ecológicos ......................................................................................... 46

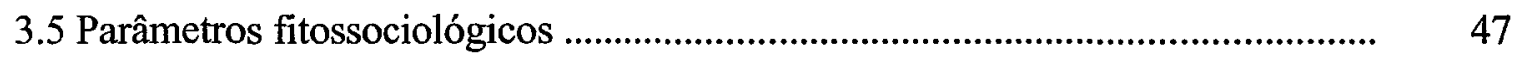

3.5.1 Estimativa da densidade para o método de quadrantes ....................................... 50

3.6 Qualificação da madeira ............................................................................... 51

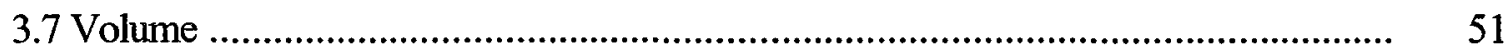

4 RESULTADOS E DISCUSSÃO _................................................................. 54

4.1 Tempo gasto para a amostragem ......................................................................... 54

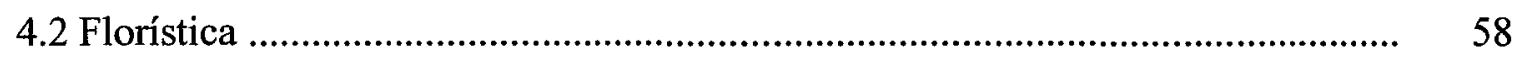

4.3 Grupos ecológicos e estrutura vertical ................................................................ 65

4.4 Fitossociologia ................................................................................................... 


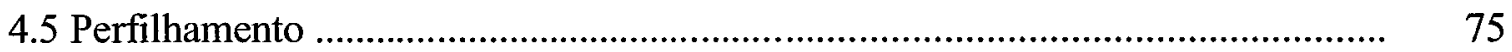

4.6 Distribuição da freqüência de árvores por classes de DAP .................................. 76

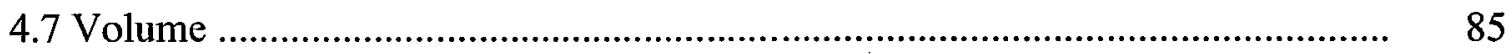

4.8 Do laudo pericial de desapropriação da Estação Ecológica dos Caetetus ............ 94

4.8.1 Introdução ..................................................................................................... 94

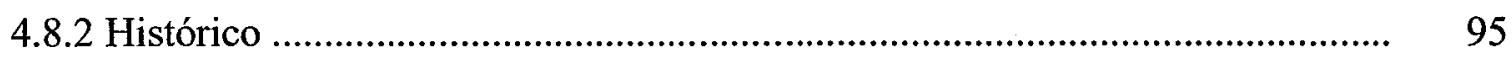

4.8.2.1 Laudo Técnico Inicial ................................................................................... 96

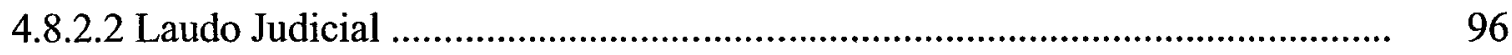

4.8.2.3 Laudos Divergentes .................................................................................... 97

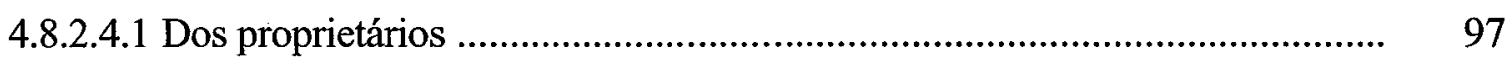

4.8.2.4.2 Da Fazenda do Estado de São Paulo ............................................................ 98

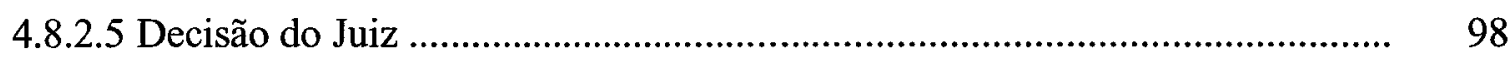

4.8.3 Consideração gerais a cerca do processo ........................................................... 99

4.8.3.1 Identificação da espécies ................................................................................ 99

4.8.3.2 Volume de madeira ........................................................................... 100

4.8.3.3 Áreas de preservação permanente ............................................................. 104

4.8.3.3.1 Declividade do solo ................................................................................ 105

4.8.3.3.2 Nascentes e cursos d'água .................................................................. 106

4.8.3.3.3 Total de área de preservação permanente …………………………………... 107

4.8.3.4 Área de Reserva Obrigatória ou Legal ..................................................... 108

4.8.4. Valor total da cobertura vegetal ........................................................................... 109

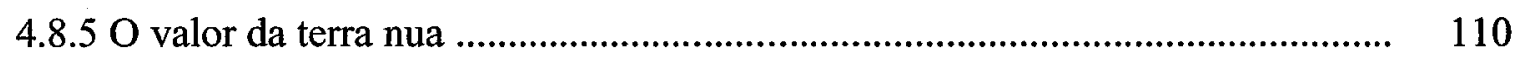

4.8.6 Estimativa do valor total da propriedade ........................................................ 110

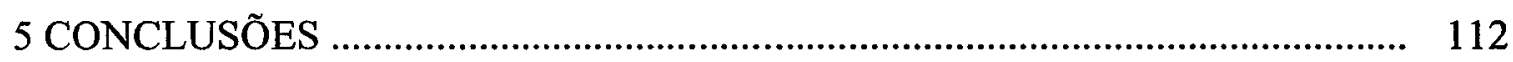

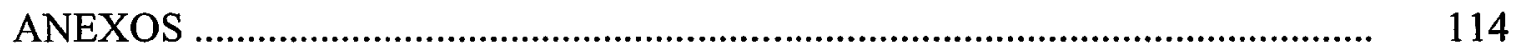

REFERÊNCIAS BIBLIOGRÁFICAS …...................................................... 140 


\section{LISTA DE FIGURAS}

Página

1 Localização da estação Ecológica dos Caetetus ………………………………….... 39

2 Localização da grade de amostragem na Estação Ecológica dos Caetetus ............. 42

3 Desenho esquemático da grade de amostragem ................................................... 44

4 Desenho esquemático de uma parcela primária, dividida em parcelas secundárias, com a localização dos pontos quadrantes ............................................ 46

5 Representação gráfica da curva do coletor para amostragem através dos métodos de parcelas e quadrantes, em floresta da Estação Ecológica dos Caetetus - Gália, SP

6 Contribuição das principais famílias em percentagem do número de gêneros, na composição florística da floresta da Estação Ecológica dos Caetetus - Gália, SP. Amostragem pelo método de parcelas

7 Contribuição das principais famílias em percentagem do número de gêneros, na composição florística da floresta da Estação Ecológica dos Caetetus - Gália, SP. Amostragem pelo método de quadrantes

8 Contribuição das principais famílias em percentagem de número de espécies, na composição florística da floresta da Estação Ecológica dos Caetetus- Gália. Amostragem pelo método de parcelas

9 Contribuição das principais famílias em percentagem de número de espécies, na composição florística da floresta da Estação Ecológica dos Caetetus - Gália, SP. Amostragem pelo método de quadrantes 
10 Contribuição das principais famílias em percentagem de número de indivíduos, na composição florística da floresta da Estação Ecológica de Caetetus - Gália, SP. Amostragem pelo método de parcelas

11 Contribuição das principais famílias em percentagem de número de indivíduos, na composição florística da floresta da Estação Ecológica de Caetetus - Gália, SP. Amostragem pelo método de quadrantes

12 Proporção dos indivíduos amostrados (\%) nos estratos, pelos métodos de parcela e quadrantes na floresta da Estação Ecológica dos Caetetus - Gália, SP

13 Percentual de indivíduos vivos amostrados pelo método de parcelas na floresta da Estação Ecológica do Caetetus, Gália - SP., considerando-se os grupos ecológicos e a estrutura vertical

14 Percentual de individuos vivos amostrados pelo método de quadrantes na floresta da Estação Ecológica do Caetetus, Gália - SP., considerando-se os grupos ecológicos e a estrutura vertical

15 Distribuição das 10 principais espécies em IVI e suas respectivas densidade, dominância e freqüência relativa na floresta da Estação Ecológica dos Caetetus. Amostragem pelo método de parcelas

16 Distribuição das 10 principais espécies em IVI e suas respectivas densidade, dominância e frequência relativas na floresta da Estação Ecológica dos Caetetus. Amostragem pelo método de quadrantes

17 - Freqüência de árvores vivas por classes de diâmetro obtidas pelo método de parcelas, na floresta da Estação Ecológica dos Caetetus - Gália, SP.

18 Freqüência de árvores vivas (\%) por classes de dâmetro obtidas pelo método de quadrantes, na floresta da Estação Ecológica dos Caetetus - Gália, SP

19 Freqüência de árvores por classes de diâmetro de Aspidosperma polyneuron, amostradas pelo método de parcelas, na floresta da Estação Ecológica dos Caetetus - Gália, SP

20 Freqüência de árvores por classes de diâmetro de Aspidosperma polyneuron, amostradas pelo método de quadrantes, na floresta da Estação Ecológica dos Caetetus - Gália, SP 
21 Freqüência de árvores por classes de diâmetro de Centrolobium tomentosum, amostradas pelo método de parcelas, na floresta da Estação Ecológica dos Caetetus - Gália, SP

22 Freqüência de árvores por classes de diâmetro de Centrolobium tomentosum, amostradas pelo método de parcelas, na floresta da Estação Ecológica dos Caetetus - Gália, SP

23 Freqüência de árvores por classes de diâmetro de Cedrela fissilis, amostradas pelo método de parcelas, na floresta da Estação Ecológica dos Caetetus - Gália, SP

24 Participação das principais espécies, na composição do volume estimado total da floresta da Estação Ecológica dos Caetetus - Gália, SP. Método de parcelas ..

25 Participação das principais espécies, na composição do volume total da floresta da Estação Ecológica dos Caetetus - Gália, SP. Método de quadrantes

26 Distribuição do volume e da quantidade de fustes amostrados pelas classes de diâmetro amostradas pelo método de parcelas, na floresta da Estação Ecológica dos Caetetus - Gália, SP

27 Estimativas de volume total da floresta pelo laudo pericial de desapropriação (L. judicial) e os inventários realizados pelo método de parcelas e de quadrantes na floresta da Estação Ecológica dos Caetetus - Gália, SP

28 Estimativas de volume por classes de valor comercial, obtido pelo laudo pericial de desapropriação (L. judicial) e os inventários realizados pelo método de parcelas e de quadrantes na floresta da Estação Ecológica dos Caetetus - Gália, SP 


\section{LISTA DE TABELAS}

\section{Página}

1 Resultados obtidos relativos ao delineamento amostral pelos métodos de parcelas e quadrantes na floresta da Estação Ecológica dos Caetetus - Gália,

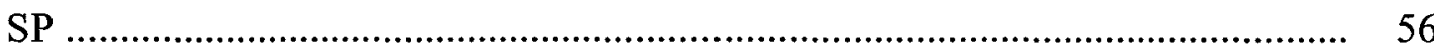

2 Espécies mais representadas em dois métodos de amostragem na floresta da Estação Ecológica dos Caetetus - Gália, SP

3 Número e percentual de espécies e indivíduos amostrados na floresta da Estação Ecológica do Caetetus, Gália - SP., considerando-se os Grupos Ecológicos

4 Participação dos grupos ecológicos na composição dos índices de Valor de Cobertura (IVC) e Valor de Importância (IVI), na floresta da Estação Ecológica dos Caetetus - Gália, SP

5 Volume das classes de madeira estudadas e suas percentagens de contribuição em relação ao estoque total, numa floresta estacional semidecidual da Estação Ecológica dos Caetetus - Gália, SP. Método de parcelas

6 Volume e percentual estimado para as madeiras de classe I, amostradas na floresta estacional semidecidual da Estação Ecológica dos Caetetus - Gália, SP

7 Volume e percentual estimado para as madeiras de classe II, amostradas na floresta estacional semidecidual da Estação Ecológica dos Caetetus - Gália, SP 
8 Volume e percentual estimado para as madeiras de classe III, amostradas na floresta estacional semidecidual da Estação Ecológica dos Caetetus - Gália,

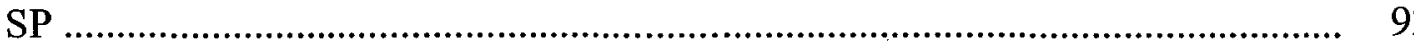




\section{LEVANTAMENTO FLORESTAL NA ESTAÇÃO ECOLÓGICA DOS CAETETUS COMO SUBSÍDIOS PARA LAUDOS DE DESAPROPRIAÇÃO AMBIENTAL}

Autor: FINÊ THOMAZ ROCHA

Orientador: Prof. Dr. JOÃO LUÍS FERREIRA BATISTA

RESUMO

Os laudos periciais que instruem processos de desapropriação de áreas de interesse ambiental, têm apresentado avaliações que freqüentemente estão associadas, entre outros aspectos, a estimativas de volume de madeira muito acima da realidade das áreas avaliadas, preço da madeira em pé exageradamente acima do que o mercado estaria disposto a pagar e estimativa de lenha abaixo da realidade. Tudo isso, tem provocado alguns desvios, acarretando super valorizações de propriedades.

Neste trabalho, foi avaliado um trecho do componente arbóreo da floresta estacional semidecidual da Estação Ecológica dos Caetetus, localizada entre os municípios de Gália e Alvinlândia, Região Centro-Oeste do Estado de São Paulo e coordenadas geográficas $22^{\circ} 41^{\prime}$ a $22^{\circ} 46^{\prime} \mathrm{S}$ e $49^{\circ} 10^{\prime}$ a $49^{\circ} 16^{\prime} \mathrm{N}$. Foram comparados os resultados relativos à composição, estrutura e estoque de madeira, obtidos por dois 
métodos de amostragem, com os dados apresentados no laudo de desapropriação da gleba, que hoje é a Estação Ecológica dos Caetetus.

Efetuou-se o levantamento fitossociológico, utilizando-se os métodos de parcelas de área fixa e de pontos quadrantes. Foi estabelecida uma grade de 64 parcelas de $90 \mathrm{~m}^{2}$ $(10 \times 90 \mathrm{~m})$ sistematicamente distribuídas e em cada parcela, foram instalados 5 pontos quadrantes, totalizando 320 pontos e a amostrados todos os indivíduos com DAP $\geq 5 \mathrm{~cm}$. Os 7.520 indivíduos amostrados nas parcelas distribuíram-se em 45 famílias, 106 gêneros e 140 espécies, enquanto nos pontos quadrantes (1280 indivíduos) foram amostrados 35 famílias, 76 gêneros e 95 espécies. As famílias mais representadas foram Myrtaceae, Mimosaceae, Meliaceae, Euphorbiaceae, Rutaceae, Lauraceae, Flacourtiaceae, Sapindaceae e Fabaceae. Constatou-se tratar de uma floresta madura, uma vez que $77 \%$ dos indivíduos amostrados pertencem às fases tardias da sucessão ecológica. Cerca de $70 \%$ dos indivíduos amostrados estão no sub-bosque. As espécies com maior IVI pelos dois métodos foram: Metrodorea nigra, Aspidosperma polyneuron, Ocotea indecora, Centrolobium tomentosum, Trichilia catigua, Syagrus romanzoffiana, Balfourodendron riedelianum, Gallesia integrifolia e Chrysophyllum gonocarpum. As espécies que mais apresentaram indivíduos perfilhados foram $M$. nigra $(8,42 \%$ nas parcelas e $8,03 \%$ nos quadrantes) e $O$. indecora $(41,35 \%$ nas parcelas e $38,46 \%$ nos quadrantes). $\mathrm{O}$ valor total da floresta estimado pela amostragem por parcelas foi de $170,56 \mathrm{~m}^{3} \mathrm{ha}^{-1}$ com $32,27 \mathrm{~m}^{3} \mathrm{ha}^{-1}$ de madeiras de classe $\mathrm{I}, 17,07 \mathrm{~m}^{3} \mathrm{ha}^{-1}$ de madeira de classe II, $28,68 \mathrm{~m}^{3} \mathrm{ha}^{-1}$ de classe II e 92,54 $\mathrm{m}^{3} \mathrm{ha}^{-1}$ de lenha. Pelo método dos quadrantes foi estimado um volume total de $169,66 \mathrm{~m}^{3} \mathrm{ha}^{-1}$, sendo $31,18 \mathrm{~m}^{3} \mathrm{ha}^{-1}$ de madeiras de classe I, 15,03 $\mathrm{m}^{3} \mathrm{ha}^{-1}$ de madeira de classe II, 27,26 m³a $\mathrm{ha}^{-1}$ de classe III e $92,19 \mathrm{~m}^{3} \mathrm{ha}^{-1}$ de lenha. Os dois métodos mostraram-se eficientes para estimar o volume da floresta estudada Ao final, constatou-se que os valores apresentados no laudo de desapropriação, foram super estimados em 44,24\%. 


\title{
FOREST SURVEY AT CAETETUS ECOLOGICAL STATITION \\ AS AN AID FOR JUDICIAL EXPERT REPORTS \\ FOR ENVIRONMENTAL DISPOSSESSION
}

\author{
Author: FINÊ THOMAZ ROCHA \\ Adviser: Prof. Dr. JOÃO LUÍS FERREIRA BATISTA
}

\section{SUMMARY}

Expert reports for judicial processes of dispossession of properties with public environmental importance are frequently related to evaluations with problems such as: overestimation of wood production of evaluated areas, wood price well above market prices and underestimation of firewood production. As result, properties under process of dispossession is often overvalorized.

This study evaluated a track of semidecidual seasonal forest of Caetetus Ecological Station, located in Gália and Alvilândia counties, in the Center-West region of São Paulo State, between the geografic coordenates 22o41' e 22o 46'S and 49o 10' e $49{ }^{1} 16^{\prime} \mathrm{N}$. Tree species composition, forest structure and wood stock estimates, obtained by two sampling methods, were compared to the estimates presented in the judicial expert report that based the process of dispossession of the property that became the Caetetus Ecological Station.

The phytossociological survey used 64 fixed area plot $(10 \times 90 \mathrm{~m})$ in a sampling grid of $100 \times 100 \mathrm{~m}$. The center-quater method was also implemented with 5 sampling 
points per fixed area plot, adding up 320 sampling points in the study area. Only trees with D.B.H. greater of equal to $5 \mathrm{~cm}$ were sampled. Fixed area plot method sampled 7520 trees of 45 botanical families, 106 genera and 140 species, while the center-quater method sampled 1280 trees from 35 botanical families, 76 genera and 95 species. Most frequent botanical families were Myrtaceae, Mimosaceae, Meliaceae, Euphorbiaceae, Rutaceae, Lauraceae, Flacourtiaceae, Sapindaceae and Fabaceae. The studied forest can be considered mature, since $77 \%$ of sampled trees are from late succession species. Around $70 \%$ of sampled individuals are in the undercanopy. Tree species with greater IVI (Importance Value Index) in both sampling methods were: Metrodorea nigra, Aspidosperma polyneuron, Ocotea indecora, Centrolobium tomentosum, Trichilia catigua, Syagrus romanzoffiana, Balfourodendron riedelianum, Gallesia integrifolia e Chrysophyllum gonocarpum. Species with greater proportion of sprouted individuals were $M$. nigra $(8.42 \%$ in fixed area plots and $8.03 \%$ in center-quater method) e $O$. indecora ( $42.35 \%$ in fixed area plot and $38.46 \%$ in center-quater method). Estimate of total production of the forest by fixed area plot method was $170.56 \mathrm{~m} 3 \mathrm{ha}-1$, with 32.27 m3ha-1 in wood quality class I, 17.07 in class II, 28.68 in class III and $95.54 \mathrm{~m} 3 \mathrm{ha-1}$ of firewood. The center-quater method estimate of total production was $169.66 \mathrm{~m} 3 \mathrm{ha}-1$, with 31.18 in class I, 15.03 in class II, 27.26 in class III and 92.19 m3ha-1 of firewood. Both methods are eficient in the estimation of forest wood volume. It was found that the judicial expert report that base de dispossession process of the Caetetus Ecological Station reported an estimate $44.24 \%$ greater than the estimates otained in this study. 


\section{INTRODUÇÃO}

As avaliações de terras apresentadas por laudos periciais que dão instrução a processos de desapropriação de áreas de interesse ambiental têm provocado alguns desvios, acarretando supervalorizações, sendo que estas, estão freqüientemente associadas a três fatores principais: 1) estimativas de volume de madeira muito acima da realidade das áreas avaliadas; 2) preço da madeira em pé exageradamente acima do que o mercado estaria disposto a pagar e 3) estimativa de lenha abaixo da realidade. Um exemplo claro é ressaltado por Felipe (2000), revelando que nos precatórios expedidos no período de 1992 a 1999, em valores atualizados em junho de 1999, as ações ambientais representaram cerca de $58 \%$ do valor, perfazendo o montante de $\mathrm{R} \$ 2.5$ bilhões. Essas ações, no entanto, representam apenas 1,6\% dos processos em tramitação.

Azevedo (1995) comenta que em 1987, estimava-se apenas para a regularização fundiária da Mata Atlântica, ao longo da costa brasileira, U\$ 2 bilhões.

Dependendo da localização e das condições da propriedade, os laudos periciais anexados a esses processos, normalmente apresentam o valor total da área como sendo a soma de dois ou mais dos seguintes componentes: os valores de equipamentos e infraestrutura (imóveis, estradas, plantios agrícolas, pastagens, etc), da terra nua e da cobertura vegetal.

Os valores dos equipamentos e infra-estrutura têm representatividade diferenciada conforme o tamanho da propriedade. Em imóveis urbanos, sítios $\mathrm{e}$ chácaras, esse componente assume uma grande percentagem do total. De maneira contrária, os equipamentos, as casas e os galpões localizados em fazendas de grande porte, não representam valores muito significativos, ficando diluídos no valor total da propriedade (SchwenckJr., 2000). O método comumente aplicado para a valoração da 
terra nua, é o comparativo. Esse método considera os preços praticados na região, obtidos através de pesquisa em imobiliárias e corretores. É feito um tratamento estatístico das observações coletadas, estimando-se a média ponderada, após a aplicação de um processo de homogeneização dos dados. Existe uma concordância geral quanto à utilização desse método. Entretanto, são comuns avaliações acima do que o mercado estaria disposto a pagar pela terra, nessa fase. Lamac (1999), observa que em alguns casos, os peritos transpõem o valor de lotes dotados de condições privilegiadas como topografia plana e fácil acesso para a gleba, objeto do processo, que pode estar localizada em condições opostas, ou seja, em topografia acidentada e difícil acesso. Posteriormente utilizam o que denominam "fatores de homogeneização", pelos quais reduzem entre $20 \%$ e $30 \%$ o valor do hectare e, o resultado obtido, é aplicado para a metragem total da gleba. No entanto, não é o valor estimado para a terra nua que mais contribui para a supervalorização das glebas.

É na atribuição do valor da cobertura vegetal onde são observados os maiores problemas quanto à obtenção de valores "astronômicos" das indenizações ambientais. Em alguns casos ocorrentes na Serra do Mar, Schwenck Jr. e Azevedo (1998) observaram que o valor desse componente chega a representar mais de 30 vezes aquele da terra nua, resultando em um valor exorbitante à propriedade.

A grande dificuldade para a elaboração de uma avaliação econômica realista para a cobertura vegetal é decorrente, entre outros fatores, da complexidade das relações inter e intra-específicas dos indivíduos que formam o componente arbóreo das comunidades vegetais. Para Oliveira Filho et al. (1994), o estudo detalhado sobre a composição florística e a estrutura ecológica das comunidades vegetais é fundamental para embasar qualquer iniciativa de preservação e conservação de remanescentes florestais, bem como para a avaliação econômica de seus recursos.

Dentre os recursos que podem ser extraídos da floresta, o principal produto comercial é a madeira. Para a obtenção da estimativa do estoque existente na gleba, é importante a necessária a realização de um inventário florestal. Este procedimento é baseado em princípios estatísticos de amostragem, com a demarcação de unidades amostrais, identificação e mensuração das árvores nelas presentes. A classificação 
comercial das espécies identificadas, presentes na floresta, é o que mais influencia na composição do preço e na exploração da floresta área (Jankowsky e Batista, 1998).

Apesar disso, os levantamentos florestais que dão base para os laudos periciais de desapropriação são realizados das maneiras mais diversas. Existem casos em que os volumes de lenha e madeira são inferidos através de pesquisas com pessoas tidas como experientes (normalmente donos de serrarias na região), que opinam sobre o rendimento possível de madeira do local. Em outros casos, são levados em consideração os resultados encontrados por outros inventários, feitos em locais de fitofisionomias semelhantes, mesmo aqueles realizados em regiões distantes. São raras às vezes em que os inventários são realizados na área do proprietário requerente da indenização, respeitando procedimentos técnicos consagrados, como: apresentação do quadro de amostras; cálculo do erro amostral e do mínimo de amostras; utilização de imagens e carta florestal para a estimativa de área e estratificação da floresta, etc. Alguns dos trabalhos mais utilizados para comparação dos resultados dos inventários nos processos de desapropriação, são os de Heinsdjik (1963) e Heinsdjik e Campos (1967). Esses inventários apresentam estimativas de volumetria para áreas da região amazônica e região sul da Mata Atlântica do Estado de São Paulo, respectivamente.

Camargo (1995), ao analisar vários processos em tramitação na Procuradoria Geral do Estado de São Paulo observou, de imediato, que existem grandes distorções quanto à definição da densidade arbórea que é encontrada em diversas áreas da Serra do Mar, contrastando com as regiões dos Parques Florestais. Em tais processos, o volume estimado de madeira variou de $50 \mathrm{~m}^{3}$ por hectare em áreas do Parque Estadual de Juréia/Itatins, a $340 \mathrm{~m}^{3}$ por hectare em Itapeuna/Eldorado Paulista.

Entretanto, não são apenas as informações sobre volume de madeira e lenha que chamam a atenção nos inventários florestais anexados a laudos periciais. Normalmente, são encontrados também outros problemas, referentes à identificação taxonômica dos indivíduos, que é feita de maneira incompleta ou com incorreções. Sabe-se que não basta a identificação parcial, pois plantas do mesmo gênero, porém de espécies diferentes, podem ter características da madeira (Rocha et al. 2000) e valores de mercado diferentes 
(Schwenck Jr. e Azevedo, 1998; Schwenck Jr. 2000). É preciso identificar a espécie com exatidão, se o objetivo é saber o seu potencial econômico.

Outro aspecto a ser considerado de maneira séria nos laudos periciais que instruem processos de desapropriação, é o enquadramento correto da possibilidade de utilização da terra, conforme a legislação ambiental vigente. As restrições impostas por Lei, principalmente quando estas impedem qualquer exploração florestal na área, influenciam no seu valor final, uma vez que não há porque se incluir o valor da cobertura vegetal da área com restrições, pois esta não poderá ser explorada, como é o caso das APPs (áreas de preservação permanente). Segundo Magalhães (1990), para se saber quais os direitos e quais as restrições que incidem sobre o uso da propriedade florestal, é necessário que se tenha noções de direito público e de direito privado. Isto porque, as florestas, são objeto do direito de propriedade, e estão sujeitas às mesmas regras que disciplinam esse direito.

A cobertura vegetal da Estação Ecológica dos Caetetus, área de estudo do presente trabalho, é caracterizada como floresta estacional semidecidual e, portanto, não faz parte da encosta atlântica. Entretanto, este tipo florestal representa um ambiente extremamente importante, que está sendo cada vez mais ameaçado pela necessidade de novas áreas para agricultura e pecuária. Por isso, acredita-se que será cada vez mais crescente a demanda por desapropriações de áreas que ainda contenham floresta estacional semidecidual, com o objetivo de preservar e conservar porções preciosas desse ecossistema importantíssimo para as futuras gerações. Sabe-se que hoje, esse tipo florestal é representado apenas por pequenos fragmentos localizados principalmente em áreas não agricultáveis, além de algumas unidades de conservação, no Estado de São Paulo (Kronka et al. 1993).

O presente trabalho busca contribuir para o estabelecimento de um protocolo de procedimentos de análise de vegetação, para a elaboração de laudos periciais, especialmente aqueles que tratam de áreas que são alvo de desapropriações ambientais.

São objetivos deste estudo: 
a) Ampliar o conhecimento da composição florística e estrutura do componente arbóreo e subsidiar o Plano de Manejo da Estação Ecológica dos Caetetus;

b) analisar e comparar a eficiência dos principais métodos de amostragem de vegetação florestal, de parcelas de área fixa e de pontos quadrantes, na obtenção da quantificação e qualificação da madeira em pé presente no componente arbóreo da vegetação em um trecho da floresta estacional semidecidual na Estação Ecológica dos Caetetus;

c) verificar como as leis vigentes e da época da desapropriação desta área (1976), restringiriam a exploração florestal da Unidade de Conservação e,

d) comparar os dados obtidos nos itens anteriores, com o que foi considerado para o pagamento no processo original de desapropriação.

O presente trabalho faz parte do projeto temático "Métodos de inventário da biodiversidade de espécies arbóreas” (BIOTA/FAPESP n 99/085-0).

As informações sobre as características fisionômicas e dendrométricas do componente arbóreo de uma porção de vegetação são importantes para a elaboração correta da valoração de uma propriedade com cobertura florestal. Assim, tanto a florística, a estrutura da vegetação como o volume da madeira, serão aspectos primordiais a serem observados pelo perito em suas vistorias.

Para o caso específico dos laudos periciais de desapropriação ambiental, os volumes de produtos madeireiros, compostos por toras e lenha são parâmetros que têm sido considerados com maior atenção na valoração de propriedades. Entretanto, não basta apenas o cálculo do volume total da gleba, são também necessárias informações claras da distribuição deste em classes de diâmetro e entre as espécies.

É interessante ressaltar que, para uma área em processo de desapropriação com a finalidade de preservação e conservação do patrimônio ambiental nela existente, outras informações, tais como: parâmetros fitossociológicos e a distribuição do número de árvores em classes de diâmetro tanto da comunidade, como das populações 
representadas, deverão auxiliar na determinação do preço da propriedade, e assim, fornecer subsídios necessários ao juiz da causa, para a tomada de sua decisão. Assim, um levantamento de caracterização da vegetação bem sustentado tecnicamente, pode ser considerado como uma das principais ferramentas de orientação para um bom laudo pericial.

Espera-se com este trabalho contribuir para o aprimoramento de técnicas que possibilitem a realização de laudos periciais de avaliação de áreas de florestas naturais, fornecer informações que subsidiem as atividades de manejo, conservação e educação ambiental realizadas na Estação Ecológica dos Caetetus, bem como, fornecer informações que possam ser utilizadas para comparação de parâmetros de diversidade com as outras áreas do projeto temático ou mesmo, entre outras áreas florestais do estado. 


\section{REVISÃO DE LITERATURA}

\subsection{Considerações sobre amostragem - base para os levantamentos.}

O embasamento técnico do levantamento florestal é condição primordial para a confiabilidade do laudo pericial. Logicamente, a realização de um censo, onde todas as árvores existentes na propriedade sejam medidas e avaliadas, é uma tarefa praticamente impossível, uma vez que, em se tratando de desapropriação para áreas de conservação, a gleba a ser analisada normalmente é de grande extensão. Nesse caso, apesar do levantamento da vegetação, através de técnicas de amostragem, apresentar-se como a alternativa recomendada, é comum observar-se laudos onde o procedimento de amostragem não possui sustentação estatística.

Segundo Pimentel Gomes (1987), a amostragem é a parte da estatística que nos ensina a obter amostras representativas de uma população. Batista (1998), comenta que a representatividade de uma amostra da floresta deve se fundamentar nos princípios de amostragem estatística e apresenta os princípios básicos de amostragem e sua utilização em levantamentos e análise de vegetação florestal.

A amostragem de comunidades florestais, de acordo com Mueller - Dombois \& Ellenberg (1974), deve preencher algumas exigências, tais como:

a) ser suficientemente grande para conter o maior número de espécies pertencentes à comunidade estudada;

b) o ambiente deve ser uniforme (clima, solo, altitude), dentro da comunidade;

c) a cobertura vegetal deve ser a mais homogênea quanto possível. 
Independentemente do tipo de amostragem, existem algumas etapas a serem trilhadas, quando da seleção de alternativas possíveis (Mateucci \& Colma, 1982; Higuchi et al., 1982), tais como: escolha da área de estudo, definição do método de amostragem, determinação do tamanho e da forma da unidade amostral a ser utilizada e cálculo do número de unidades amostrais. Entretanto, mesmo considerando essas alternativas, não se pode afirmar que exista um método de amostragem universal, capaz de ser aplicado em qualquer situação.

Martins (1978) afirma que o método de levantamento de vegetação florestal será tanto melhor quanto maior número de informações fornecer, com um grau razoável de precisão, e quanto mais fácil for sua aplicação em campo.

\subsection{Levantamentos de vegetação}

\subsubsection{Importância}

A cobertura vegetal de um determinado lugar resulta de causas atuais, tais como: clima, solo e da ação da fauna (Baitello et al., 1997). Os indivíduos da mesma espécie que podem reagir diferentemente a essas causas compõem uma população, e grupos de populações que ocorrem juntas, caracterizam uma comunidade (Ricklefs, 1993). As comunidades podem diferenciar-se, dependendo das interações das espécies e com o meio abiótico (Martins e Santos, 1999).

O componente arbóreo exerce um papel fundamental no funcionamento da comunidade florestal. Bryant (1999), assinalando a significância das árvores para a conservação da biodiversidade como um todo, estima em 50.000 o número total de espécies arbóreas nos trópicos, enquanto que o número total de artrópodes na mesma região chegaria a 30 milhões. Entretanto, o autor estima que se $50 \%$ das espécies arbóreas desaparecessem, o número de artrópodes também seria reduzido pela metade.

Considerando-se então essa multiplicidade de fatores atuando no ambiente florestal, pode-se concluir que, entender as relações intra e interespecíficas da 
comunidade, não é uma tarefa simples. Assim, o conhecimento da composição florística e da estrutura fitossociológica da comunidade são critérios básicos para uma avaliação criteriosa, inclusive para a própria escolha do método de levantamento. Este será tanto melhor quanto maior for a quantidade de informações que fornecer com um grau razoável de precisão, e quanto mais fácil for sua aplicação no campo (Martins, 1978).

A composição florística das espécies e a estrutura da vegetação são características qualitativas e quantitativas da comunidade florestal. No caso das características quantitativas, usualmente busca-se descrever a estrutura através de descritores como: número de indivíduos, densidade e área basal por unidade de área amostrada por espécie encontrada e volume de madeira. A partir desses dados é possível obter-se outras informações relacionadas à diversidade de espécies, riqueza e eqüabilidade (Dislich et al., 2001). Quanto às características qualitativa s, os resultados dos levantamentos podem ser apresentados através da relação das espécies ocorrentes na área estudada (Causton, 1988), juntamente com o enquadramento dessas espécies aos respectivos grupos ecológicos.

Os métodos empregados em levantamentos fitossociológicos, segundo Daubenmire (1968) apud Schlittler (1990), divide-se, basicamente, em três grupos: o de parcela única, o de parcelas múltiplas e sem parcelas.

O método de parcela única não permite o cálculo da variabilidade dos parâmetros estudados, sendo por isso utilizado normalmente em inventários florestais, cujo objetivo é fornecer estimativas globais da fitocenose (Bardin, 1974) apud Schlittler (1990).

As parcelas múltiplas podem ser distribuídas dentro da vegetação de maneira aleatória ou sistemática. Quando as parcelas são estabelecidas ao acaso, a fitocenose deve ser encarada como homogênea, enquanto que a sistematização das parcelas deve ser realizada quando a fitocenose se apresenta heterogênea em sua composição fisionômica, permitindo comparações de variações (Martins, 1978).

Quanto ao estudo de áreas florestais, Martins (1989) relata que os primeiros levantamentos em terras brasileiras foram determinados pela necessidade de obtenção de informações fundamentais para a otimização às epidemias de febre amarela e malária. 
Kurtz e Araújo (2000) comentam que esses levantamentos foram realizados no Estado do Rio de Janeiro.

Schlittler (1990) comenta que os primeiros trabalhos feitos no Brasil utilizaram o método de parcelas, aplicando técnicas propostas por Braun-Blanquet (1979).

Quanto aos métodos sem parcelas, estes se baseiam no conceito fundamental da distância média entre os indivíduos (Müeller-Dombois \& Ellenberg, 1974). O método de quadrantes (Point Centered Quarter Method) é um tipo de amostragem baseado em distância. Cottam \& Curtis (1956) mencionam que esse método fornece mais dados por ponto de amostragem e é menos sujeito a erros subjetivos quando comparado com outros métodos de distâncias. Entre as suas principais vantagens, Martins (1979) ressalta a eliminação da influência da forma de parcela sobre os resultados, a facilidade na locação dos pontos de amostragem, a área de amostragem maior, resultando em maior conhecimento da vegetação, a maior consistência na comparação dos resultados obtidos em diferentes povoamentos do mesmo tipo de vegetação e o ganho de tempo no campo.

\subsubsection{Método de quadrantes}

A aplicação deste método consiste no estabelecimento de pontos distribuídos dentro do povoamento a ser amostrado. Cada ponto é dividido em quatro quadrantes, e em cada um destes, é amostrado o indivíduo mais próximo ao ponto. Registra-se para cada indivíduo a identificação botânica correta, o diâmetro (no caso de levantamentos florestais é mais comum ser medido à altura do peito - DAP), a altura total e a distância ponto-árvore. Martins (1993), discute amplamente o método de quadrantes e recomenda o seu uso, sempre que possível, no estudo de florestas. Entre as vantagens deste método, Martins (1979) ressalta: eliminação da influência da forma de parcela sobre os resultados; maior área de amostragem, resultando em maior conhecimento da vegetação; maior consistência na comparação dos resultados obtidos em diferentes povoamentos do mesmo tipo de vegetação e ganho de tempo no campo. Cottan e Curtis (1956) mencionam que o método de quadrantes fornece mais dados por ponto de amostragem e é menos sujeito a erros subjetivos, quando comparados com outros métodos de distância. 
Goodland (1971), apud Schlittler (1990), foi o pioneiro na aplicação do método de quadrantes no Brasil, estudando uma área de cerrado no Triângulo Mineiro.

No Estado de São Paulo, um dos primeiros levantamentos fitossociológicos foi realizado por Martins (1979), que além de descrever a origem dos métodos baseados em distância, aplicou o método de quadrantes para analisar uma área de floresta estacional semidecidual no componente arbóreo do Parque Estadual de Vassununga.

Posteriormente, vários outros estudos utilizando o método de quadrantes, foram realizados no Estado de São Paulo, estando entre estes: Cavassan et al. (1984) na Reserva Estadual de Bauru, Pagano et al (1987) no município de Rio Claro, Cesar (1988) na fazenda Barreiro Rico, município de Anhembi, Dias (1993) no Parque Estadual de Carlo Botelho, Baitello et al. (1993) no Parque Estadual da Cantareira, Cidade de São Paulo, Mantovani (1993) na Estação Ecológica da Juréia-Itatins, no litoral sul do Estado de São Paulo, Schlittler (1990) e Schlittler et al. (1995) Parque Estadual do Morro do Diabo, na região do Pontal do Paranapanema.

\subsubsection{Método de Parcelas}

Os primeiros métodos quantitativos empregados em levantamentos fitossociológicos, segundo (Martins 1978), consistiam no estabelecimento de pequenas parcelas quadradas dentro da área que se desejava estudar, daí o nome de método de quadrados, com o qual também é conhecido.

Ainda, segundo o mesmo autor, tal como na Europa, os estudos fitossociológicos surgiram no Brasil com a aplicação do método de parcelas, utilizando técnicas de análise de Braun-Blanquet (1979). Esse método é bastante conhecido, tradicional e seu tratamento matemático é conhecido embora sua forma de amostragem seja subjetiva e não estatística. Sua aplicação no Brasil tem cerca de meio século.

Feliciano et al. (2000), avaliaram as características estruturais de um fragmento de floresta estacional semidecidual no município de Brotas. Instalaram 44 parcelas de $100 \mathrm{~m}^{2}$ em 4 transectos em área da Estação Ecológica de São Carlos. Observaram que entre as 81 espécies encontradas, 3 delas estão ameaçadas de extinção na categoria 
vulnerável. Os indivíduos arbóreos produziram uma área basal de $45,98 \mathrm{~m}^{2} / \mathrm{há}^{\text {, }}$ produzindo um volume total de $609,95 \mathrm{~m}^{3} / \mathrm{ha}$.

Dentre os trabalhos mais recentes que aplicaram o método de parcelas para o levantamento de vegetação florestal, particularmente aqueles realizados em áreas representativas de floresta estacional semidecidual no estados de São Paulo, pode-se citar: Cavassan e Martins (1997) em Bauru, Figueiredo (1993) em Angatuba, Ivanauskas et al. (1999) no município de Itatinga, Ivanauskas et al. (2000), Nascimento et al. (2002) em Piracicaba e Silva \& Soares (2002) no município de São Carlos.

$\mathrm{Na}$ maioria desses trabalhos pouca referência é feita quanto ao delineamento amostral (aleatório simples, sistemático, etc) e talvez o conceito subjetivo de locais representativos de Brau-Blanquet ainda seja muito utilizado.

\subsubsection{Inventários Florestais}

$\mathrm{Na}$ valoração de propriedades, com cobertura florestal, envolvidas em processos de desapropriação ambiental que formarão ou serão parte de unidades de conservação, são considerados os benefícios econômicos diretos que seriam proporcionados, principalmente, pela retirada da madeira. Assim, nesse trabalho, serão discutidos alguns importantes itens que compõem a valoração da madeira, tais como: classificação comercial das espécies identificadas, estoque e preço da madeira. Estes aspectos, avaliados através de levantamento florestal, interferem determinantemente na composição do valor final da área. Além desses, o preço da madeira em pé também tem importância fundamental na determinação do valor da propriedade, pois há casos em que o perito atribui preço de madeira serrada à madeira em pé.

A valoração da floresta em pé, que é uma proposta de avaliação do povoamento de fácil execução, pode gerar informações úteis sobre a viabilidade econômica da exploração pela indicação do potencial de madeira do local.

O método usual para a obtenção de informações sobre a estimativa do estoque madeireiro de uma floresta é o inventário, que segundo Netto \& Brena (1997) e Rollet e 
Queiroz (1978), é a atividade que visa obter informações qualitativas e quantitativas de recursos florestais existentes em uma certa área, tais como volume, área basal, etc.

Higuchi et al. (1982) comentam que o objetivo de qualquer inventário florestal é obter o máximo de informações de uma floresta com a máxima precisão e mínimo custo.

No entanto, elaborar um inventário em uma floresta nativa é uma atividade que requer planejamento detalhado. IBGE (1992), relaciona inventários florestais quanto ao seu detalhamento, classificando-os em: a) inventário florestal de reconhecimento, quando fornece informações generalizadas que permitem identificar e delimitar áreas de grande potencial madeireiro, detectar áreas que sejam passíveis de uso indireto (recreação, lazer), indicar áreas com vocação florestal, entre outros; b) inventário de semidetalhe, realizado com base nos resultados do inventário de reconhecimento, sendo suas principais características: fornecer estimativas mais precisas relacionadas aos parâmetros da população; ter escala compatível com o nível de informação que se quer obter (normalmente entre 1:50000 e 1:100000); permitir a definição de áreas para exploração florestal através de talhões de tamanhos variáveis normalmente entre 10 a 100ha. e c) inventário de pré-exploração, também conhecido como inventário $100 \%$ de intensidade ou de detalhe, sendo suas principais características: mensuração de todos os indivíduos na área demarcada e os cuidados principais relacionados com os erros de medição, uma vez que não existe o erro estatístico devido à amostragem.

Segundo Rollet e Queiroz (1978) e Imanã-Encinas (1991), os primeiros inventários florestais executados no Brasil tiveram início na região amazônica, através de levantamentos realizados pela missão FAO - Heinsdjik (1958).

Ao serem analisados trabalhos realizados nos diferentes biomas, verifica-se que o volume de madeira encontrado varia de acordo com o tipo florestal avaliado. Os trabalhos citados a seguir dão um pequeno exemplo disso.

Um dos primeiros inventários de vegetação nativa em terras públicas do Estado de São Paulo foi realizado por Heinsdjik \& Campos (1967), onde os autores trabalharam numa área de 37.011 hectares composta por floresta latifoliada tropical úmida de encosta pertencente aos municípios de Capão Bonito, Sete Barras e São Miguel Arcanjo. O objetivo inicial foi delimitar as terras florestais do Estado. Os autores adotaram como 
diâmetro de inclusão das árvores, o valor de $25 \mathrm{~cm}$. Para estimar volume, utilizaram a Tabela Geral de Volumes, confeccionada pelo Departamento de Estatística da Organização Central para Pesquisas Científicas Aplicadas, da Holanda, o mesmo processo aplicado em inventários da região Amazônica, baseados em Heinsdijk (1963). Foi feita uma distribuição de lnhas de amostragem "quase ao acaso" em quatro regiões, sendo: Carlos Botelho, Capão Bonito, Sete Barras e Travessão. Ao longo dessas linhas, instalaram parcelas de $0,2 \mathrm{ha}$ eqüidistantes $200 \mathrm{~m}$. O volume total estimado para a floresta foi de $104,47 \mathrm{~m}^{3}$ e o volume comercial estimado foi de $42,94 \mathrm{~m}^{3}$ por hectare, correspondendo a $41,10 \%$ do volume total estimado. Os autores ressaltam que esse volume é baixo, comparativamente com dados do Espírito Santo e Amazônia.

Em outro trabalho, Campos \& Heinsdjik (1970) realizaram inventário numa amostra de 0,4ha. utilizando linhas de exploração, atravessando as melhores partes da Reserva Estadual do Morro do Diabo cuja a cobertura é classificada como floresta latifoliada tropical semi-decídua. Essa reserva localiza-se no município de Teodoro Sampaio, extremo Oeste do Estado de São Paulo. As unidades amostrais foram distribuídas sistematicamente, eqüidistantes 400 metros ao longo das linhas. A vegetação foi classificada em 4 (quatro) tipos segundo a densidade e altura total das árvores, sendo eles: Tipo I - correspondente à vegetação mais densa da área, compreendendo árvores mais altas, com maior densidade e altura média de 15 metros; Tipo II - vegetação menos densa que a anterior, de menos altura média (13 metros); Tipo III - vegetação considerada de transição entre os tipos II e IV, e mais heterogênea que os tipos citados anteriormente, e Tipo IV - desprovido de árvores de grande porte. Classificaram as espécies encontradas em 4 grupos, conforme o valor comercial, porém, os grupos 3 e 4 não foram detalhados por constituírem-se de madeira de pouco valor comercial. Estimaram o volume total de madeira de $54,39 \mathrm{~m}^{3} \mathrm{ha}^{-1}\left(25,37 \mathrm{~m}^{3}\right.$ para espécies do grupo 1 e $12,32 \mathrm{~m}^{3}$ para aquelas do grupo 2) para o tipo florestal I e $26,16 \mathrm{~m}^{3} \mathrm{ha}^{-1}$ $\left(13,66 \mathrm{~m}^{3}\right.$, grupo 1 e $4,76 \mathrm{~m}^{3}$ do grupo 2) para o tipo florestal II.

Figueiredo et al. (1982) testaram uma série de modelos de regressão para a estimativa volumétrica por unidade de área a partir de variáveis como: diâmetro médio aritmético, altura média, área basal e número de árvores por hectare, em dois grandes 
estratos - floresta de várzea e floresta de terra firme, localizadas na Floresta Tropical Úmida da Região Amazônica - nos municípios de Tefé e Juruá. Concluíram que, dos modelos testados, apenas 6 deles apresentaram-se com possibilidades de uso, tanto para floresta de várzea, como de terra firme e que os modelos que utilizaram tão somente da medição de área basal por hectare podem ser utilizados para levantamentos em que a precisão não seja um rigor acentuado.

Paula et al. (1996), avaliaram a biomassa da mata ripária do Córrego dos Macacos no Estado de Goiás e obtiveram uma estimativa de volume de $182 \mathrm{~m}^{3} / \mathrm{ha}$. O estudo foi realizado em uma área contínua de um hectare, dividida em dez parcelas de $1000 \mathrm{~m}^{2}$ e foram considerados os indivíduos que apresentaram DAP igual ou superior a $15 \mathrm{~cm}$.

Imaña-Encinas (1991), realizou inventário numa área com cobertura de cerradão com 32 hectares, utilizando modelo de linhas de amostragem, tendo medido 20 parcelas de $600 \mathrm{~m}^{2}$ cada. O volume médio estimado foi de $38,32 \mathrm{~m}^{3}$.

Bentes-Gama et al. (2002), elaboraram a valoração de uma floresta de várzea alta não explorada na Amazônia, considerando o volume de madeira como componente principal de preço. Adotaram categorias de usos das espécies e, dentre os resultados obtidos, destacam a observação na área estudada, de 8 espécies comerciais, 13 espécies potenciais e 56 não comerciais. Concluíram que os diagnósticos florísticos e estruturais associados à valoração da floresta em pé, apresentaram-se como ferramentas importantes e viáveis na obtenção de informações sobre a floresta estudada.

\subsection{Comparação de métodos}

Objetivando comparar métodos de amostragem com relação à suas precisões relativas e outras características, Cottam \& Curtis (1956), realizaram um estudo em 3 comunidades florestais e uma população aleatória gerada artificialmente. Avaliaram os seguintes métodos: parcela (método de área) e 4 métodos de distância: ponto quadrantes, pares aleatórios, distância ponto planta e distância planta-planta. Dentre as conclusões do estudo destacam-se: todos os métodos de distância foram capazes de gerar resultados 
precisos quando a amostra é adequada; o método planta-planta apresentou menos variação dos dados, porém requer um grande número de pontos amostrais. Consideram o método de parcelas superior aos demais por apresentar menor variação dos dados; ter base matemática conhecida e não precisar de nenhum fator de correção, porém, apontam como a principal desvantagem desse método, o maior tempo requerido para a obtenção dos dados de campo. Os autores também consideraram o método de quadrantes superior aos demais métodos de distância, recomendando a sua utilização.

Ao comparar os métodos de parcelas e de quadrantes em uma faixa de cerrado da Fazenda Água Limpa - DF, Silva Júnior et al. (1978) avaliaram as estimativas de área basal e de densidade por hectare e a posição das espécies com base no IVI. Amostraram 2014 indivíduos utilizando o método de parcelas e 840 com o método de quadrantes. Concluíram que a análise fitossociológica não apresentou muitas diferenças no posicionamento das espécies com base nos IVIs. Com a aplicação do teste t de Student, não foram constatadas diferenças, ao nível de $5 \%$ de significância, entre as médias das densidades totais por hectare de algumas das espécies mais importantes, bem como das áreas basais totais e das espécies, por hectare. Para as espécies raras, no entanto, o método de parcelas mostrou-se mais eficiente na estimativa da densidade e de área basal/hectare.

Gibbs et al. (1980) utilizaram o método de quadrantes em levantamento floristico de uma mata ciliar do rio Mogi-Guaçu e, comparando os resultados com aqueles obtidos num estudo anterior na mesma área (Gibbs \& Leitão-Filho 1978), onde aplicaram o método de parcelas, concluíram que ambos os métodos são válidos, destacando a rapidez e a facilidade de aplicação como grandes vantagens para o primeiro, pela sua rapidez e eficiência para amostrar as espécies mais freqüentes.

Com o objetivo de eleger um método mais simples para ser aplicado na floresta pluvial tropical localizada no Núcleo Sete Barras, Parque Estadual da Serra do Mar, tendo em vista a grande dificuldade de amostrar esse tipo florestal por meio de parcelas de tamanho fixo, Dias et al. (1986), compararam 6 métodos de amostragem empregados em inventários florestais. Utilizaram, como parâmetro de comparação, o Índice de Valor de Importância (IVI) das essências, resultante da análise mediante o uso de parcelas de 
tamanho fixo. Instalaram 3 parcelas de 1 hectare $(100 \times 100 \mathrm{~m})$ cada uma, subdivididas em sub-parcelas de $100 \mathrm{~m}^{2}(10 \times 10 \mathrm{~m})$, avaliando todas as árvores com DAP igual ou superior a $15 \mathrm{~cm}$. Avaliaram o método de parcela de área fixa e os seguintes métodos de distância: a) planta mais próxima; b) pontos quadrantes; c) relascopia, com fatores 9,16 e 25 ; d) vizinho mais próximo; e) pares aleatórios e, f) método inglês. Concluíram que os IVIs obtidos com os métodos de distância ponto a planta ( $a, b$ e c) e planta a planta (d, e, f) não apresentaram diferenças significativas, com o IVI obtido através do método de parcelas fixas. Baseados em seus resultados, os autores não recomendam os métodos de relascopia com fator 25 e árvore mais próxima, para levantamentos que objetivem aspectos florísticos da floresta.

Dias et al. (1989) compararam 9 métodos de amostragem instalados no núcleo Sete Barras do Parque Estadual de Carlos Botelho. Amostraram árvores com DAP igual ou superior a $15 \mathrm{~cm}$ e compararam a obtenção do Índice de Valor de Importância (IVI) para cada método. Os autores observaram que face às características de cada método, houve alterações nos valores de IVI. Essas alterações, no entanto, não foram significativas quando comparados os 9 métodos de levantamento.

Mello et al. (1996), avaliaram a eficiência de vários procedimentos de amostragem na descrição da estrutura fitossociológica de uma floresta estacional semidecidual Montana em Minas Gerais. Aplicaram os seguintes métodos de amostragem: casual simples, casual simples com parcelas de tamanhos diferentes, casual estratificada, sistemática, sistemática com pós-estratificação e sistemática com parcelas de tamanhos diferentes. Verificaram que os seis procedimentos avaliados representaram de forma adequada os parâmetros da estrutura horizontal, entretanto, observaram que, considerando as Distâncias Euclidianas obtidas para cada procedimento, aqueles com base sistemática foram superiores aos que se basearam em aleatorização.

Reis e Assunção (1998), compararam três métodos de amostragem com o objetivo de avaliar a estimação por contagem de quadrados, através dos métodos de distância e do conglomerado adaptativo. Concluíram que, em regiões de difícil deslocamento, e se houver razões para acreditar que a população a ser estudada distribuise de modo agregado nessa região, os estimadores do conglomerado adaptativo 
mostraram-se os mais adequados, já que os quadrados estarão também agregados e, assim, os deslocamentos serão minimizados. Nessa situação, comentam os autores, o uso do método do conglomerado adaptativo para estimar o tamanho dessa população pode traduzir-se numa redução do trabalho de campo sem prejuízos da qualidade de estimação.

É importante ressaltar, que o tipo agregado de distribuição espacial, é comumente encontrado entre as espécies de plantas de florestas tropicais (Silva e Lopes, 1982).

Moscovich et al. (1999) avaliaram cinco métodos de amostragem em floresta de Araucaria angustifolia sendo, quatro de área variável (Strand, Prodan, Quadrantes e Bitterlich) e um de área fixa, para determinar a eficiência de cada um deles, nas estimativas de parâmetros quantitativos (volume, número de árvores e área basal) e qualitativos (abrangência de espécies). Verificaram que, para a floresta estudada, os métodos não apresentaram diferenças significativas na estimativa do volume, área basal e número de árvores por hectare. Constataram, no entanto, que o método dos quadrantes foi o que apresentou a menor eficiência relativa na estimação de todos os parâmetros.

Durigan et al. (2002) adotaram um método alternativo de levantamento florestal, na tentativa, de reunir o que chamaram de aspectos positivos, e eliminar aspectos negativos dos dois métodos mais amplamente utilizados, parcelas e quadrantes. $O$ método consistiu apenas na medição do diâmetro (DAP maior ou igual a $10 \mathrm{~cm}$ ) e identificação botânica dos indivíduos em 100 pontos, sem, no entanto, a medição da distância ponto-árvore. A estimativa de densidade foi efetuada com base no método de parcelas, onde, para cada cinco pontos quadrantes, levantou-se a densidade em uma parcela de $100 \mathrm{~m}^{2}$, sem que os indivíduos fossem identificados ou medidos, uma vez que a única finalidade dessa amostragem foi estimar a densidade absoluta da floresta. Concluíram que o método utilizado mostrou-se de fácil aplicação no campo e nos cálculos.

\subsection{Floresta estacional semidecidual}


A floresta estacional semidecidual foi provavelmente, o ecossistema mais devastado em todo o Brasil. Por estar localizado nas regiões mais populosas e estar geralmente associado a solos com altos índices de fertilidade, este tipo florestal foi completamente dominado pelo avanço das fronteiras agrícolas e, principalmente, pelo fato que nesse ambiente existiam grandes populações de espécies de madeiras consideradas nobres e, portanto, com elevados preços. A descontrolada extração seletiva dessas árvores também contribuiu de maneira decisiva para o virtual desaparecimento dessa forma florestal, de inestimável valor para a humanidade. Os ambientes florestais chegaram a ocupar $88 \%$ do território do estado de São Paulo (Victor, 1975). Atualmente, esse ecossistema está representado por pequenos fragmentos bastante isolados, imersos numa paisagem dominada pela agricultura e por grandes centros urbanos (Nascimento et al. 2002). Os remanescentes concentram-se, basicamente, em um reduzido número de Unidades de Conservação, que abrigam, de forma precária, o que restou da biodiversidade original.

O conceito ecológico da floresta estacional semidecidual está condicionado pela dupla estacionalidade climática, uma tropical com época de intensas chuvas de verão, seguida por estiagem acentuada e outra subtropical, sem período seco, mas com seca fisiológica, provocada pelo intenso frio do inverno, com temperaturas médias, inferiores a $15^{\circ} \mathrm{C}$. Neste tipo de vegetação, a percentagem das árvores caducifólias, no conjunto florestal e não das espécies que perdem as folhas individualmente, situa-se entre $20 \mathrm{e}$ 50\% (IBGE, 1992). Essas florestas apresentam uma alta diversidade florística e possuem uma flora arbórea bem estudada quando comparada com outras formações (Leitão-Filho (1982); Morellato (2000).

Vários autores usaram termos diferentes para denominar este tipo de vegetação, no entanto, a designação mais aceita atualmente é mesmo floresta estacional semidecidual (Rodrigues, 1989), pois, o termo estacional, expressa exatamente as transformações de aspecto ou comportamento da comunidade conforme as estações do ano. Laitão-Filho (1992) comenta que a floresta estacional semidecidual apresenta uma alta diversidade florística. 


\subsection{Trabalhos realizados na Estação Ecológica dos Caetetus}

Com relação especificamente à comunidade vegetal da Estação Ecológica dos Caetetus (EEC), Durigan et al. (2000) estudaram a estrutura do componente arbóreo através do método de parcelas com áreas variáveis para os diferentes estratos e, além das medições convencionais de altura e diâmetro, efetuaram, ainda, a contagem de lianas, considerando-se o número de caules por parcela. Os autores destacaram a baixa diversidade alfa encontrada, em comparação com outras áreas de floresta estacional semidecidual, ressaltando que a grande parte das espécies que compõem o dossel não, foram observadas em regeneração na área.

Franco (2002), caracterizou a flora da EEC e elaborou chave para identificação das espécies arbustivo-arbóreas. Realizou, também, a caracterização fitossociológica, através do método de parcelas, de dois trechos das principais unidades do mosaico florestal. Concluiu que a amostragem da área correspondente a apenas $0,09 \%$ da área total da EEC foi eficiente para avaliar as espécies arbóreas de interior de floresta.

Comparando métodos de amostragem no levantamento da comunidade arbórea da EEC, Gorenstein (2002), examinou o desempenho dos métodos de parcela de área fixa, pontos quadrantes e pontos de Bitterlich, para caracterizar a biodiversidade e concluiu que, para a área estudada, os métodos de quadrantes e Bitterlich apresentaram o mesmo comportamento para amostragem da riqueza da comunidade quando o esforço de amostragem é analisado de acordo com o número de indivíduos.

Margutti et al. (1998) realizaram inventário de cinco espécies (Chorisia speciosa, Euterpe edulis, Hymenaea courbaril, Jacaratia spinosa e Myroxylon peruiferum) com o objetivo de disponibilizar informações que possibilitassem a busca por alternativas de manejo para a conservação de populações geneticamente ameaçadas. Utilizaram amostragem aleatória em 10 conglomerados lineares de 20 parcelas de $10 \times 10 \mathrm{~m}$, distantes 30 metros uns dos outros para inventário de indivíduos adultos e parcelas de 10 x $2 \mathrm{~m}$ e $10 \times 1 \mathrm{~m}$ para regeneração. Observaram baixa densidade para as 5 espécies. $M$. 
peruiferum apresentou indivíduos em todas as classes de tamanho, enquanto que em $H$. courbaril e $C$. speciosa não apresentaram essa característica.

Stella et al. (1998), realizaram inventário específico para Euterpe edulis, objetivando verificar a distribuição de indivíduos por classes de diâmetro e sua distribuição de regeneração, por classes de tamanho, comparando três populações locais, com populações de outras áreas. Utilizaram amostragem aleatória simples em parcelas de $10 \times 60 \mathrm{~m}$, perdendiculares ao rio, 30 metros de cada lado. Concluíram que a distribuição da espécie estudada, em Caetetus, concentra-se em áreas ciliares, com a maior densidade de adultos no intervalo de 8 a $12 \mathrm{~cm}$ de DAP.

\subsection{A Legislação ambiental e o laudo de desapropriação}

\subsubsection{Introdução}

A elaboração de laudo pericial para instruir processos de desapropriação de áreas com importantes patrimônios ambientais, principalmente aquelas caracterizadas por grande extensão de cobertura florestal e de interesse público, é uma atividade complexa. As informações fornecidas pelo perito devem apresentar um determinado grau de detalhe, que facilite a tomada de decisão do juiz encarregado pelo processo, permitindo a este, o estabelecimento da justa indenização ao proprietário da área.

Dessa maneira, O perito deve responder a todos os quesitos impostos pelo juiz, bem como acrescentar outras informações que julgue, sejam necessárias. Além de dados relativos à florística e à estrutura da vegetação, a presentados no capítulo anterior, os direitos e restrições impostas tanto pela legislação ambiental, como pelo Código Florestal, devem ser considerados quando da composição do preço final da propriedade.

Nesse capítulo, serão apresentados alguns conceitos jurídicos, cujo conhecimento, poderá auxiliar profissionais e técnicos na elaboração de avaliações de propriedades rurais. Além disso, apesar de não ter como pretensão a total abordagem da legislação, será apresentada uma pequena revisão da legislação florestal referente à época da desapropriação da Estação Ecológica dos Caetetus. Essas informações deverão 
ser utilizadas no próximo capítulo, avaliando-se como essa legislação poderia ter influenciado na composição do preço final daquela propriedade, caso tivesse sido considerada de forma diferente daquela que motivou a decisão final do magistrado.

\subsubsection{Revisão conceitual}

\subsubsection{Desapropriação}

A Constituição Federal atual garante a propriedade privada nos Artigos $5^{\circ}$ e 170 . Reconhece, no entanto, a possibilidade de interferência do Poder Público na mudança compulsória da destinação de um bem, ajustando aos interesses sociais, mediante três procedimentos: a desapropriação, o confisco ou a requisição (Artigos $5^{\circ}, 182$ e 184).

A desapropriação, segundo Stucchi (1995) é a perda forçada da propriedade, nos

casos contemplados em lei como necessidade pública e interesse social, adquirindo o Poder Público originariamente $o$ bem, mediante o pagamento de justa e prévia indenização.

Entretanto, uma das questões principais que se levanta, diz respeito ao valor a ser fixado em perícia pela desapropriação do imóvel, a fim de que seja apto a tornar indene (sem dano) o expropriado (proprietário). Este valor pode, por vários motivos, deixar de refletir a garantia constitucional da justa indenização, quer em razão dos trâmites processuais, dos erros contidos na perícia, dos fatores decorrentes do próprio mercado imobiliário, quer ainda da demora no pagamento da indenização Paiva (1999). Porém, a mesma autora afirma que a justa indenização é via de mão dupla, que deve atender tanto ao expropriado como ao expropriante, sob pena de o segundo promover o confisco, ou o primeiro ser beneficiado por enriquecimento sem causa, senão ilícito.

A Constituição do Império do Brasil, de 1824, já prescrevia em seu Artigo 179, item 22, o direito de propriedade em toda a sua plenitude, destacando que "Se o bem público, legalmente verificado, exigir o uso e emprego da propriedade do cidadão, será 
ele previamente indenizado do valor dela. A lei marcará os passos com que terá lugar esta única exceção e dará as regras para se determinar a indenização".

Posteriormente, a Constituição de 1934, em seu Artigo 113, item 17 afirma: "É garantido o direito de propriedade, que não poderá ser exercido contra o interesse social ou coletivo, na forma que a lei determinar. A desapropriação por necessidade ou utilidade pública far-se-á nos termos da lei, mediante prévia e justa indenização. Em caso de perigo iminente, como guerra ou comoção intestina, poderão as autoridades competentes usar da propriedade particular até onde o bem público o exija, ressalvado o direito à indenização ulterior".

As Constituições de 1946 (Art. 141, § 16) e de 1967 (Art. 153) mantiveram, praticamente, o texto de 1934, permitindo a desapropriação por necessidade ou utilidade pública ou interesse social, mediante prévia e justa indenização em dinheiro.

O antigo Código Civil, na redação original do Art. 590, faz a distinção entre necessidade e utilidade públicas, onde se perde a propriedade imóvel mediante desapropriação por necessidade ou utilidade pública. $\S 1^{\circ}$ Consideram-se casos de necessidade pública; I - a defesa do território nacional. II - a segurança pública. III - os socorros públicos, nos casos de calamidade. IV - a salubridade pública. $\S 2^{\circ}$ Consideram-se casos de utilidade pública: I - a fundação de povoação e de estabelecimentos de assistência, educação ou instrução pública. II - a abertura, alargamento ou prolongamento de ruas, praças, canais, estradas de ferro e, em geral, de quaisquer vias públicas. III - a construção de obras, ou estabelecimentos, destinados ao bem geral de uma localidade, sua decoração e higiene. IV - a exploração de minas".

Segundo Felippe (2000), as chamadas ações ambientais imobiliárias compreendem basicamente três categorias, sendo elas:

1. Ações de desapropriação direta, proposta pelo Estado para incorporar ao seu patrimônio áreas declaradas de utilidade pública por ato do poder executivo;

2. Ações de desapropriação indireta, propostas por particulares contra o Estado, para que - em virtude de apossamento estatal - sejam as áreas particulares incorporadas ao patrimônio público; 
3. Ações indenizatórias propostas por particulares contra o Estado em virtude de possíveis prejuízos decorrentes de ato estatal restritivo do direito de propriedade, sem a transferência do imóvel ao patrimônio público.

\subsubsection{Laudo pericial}

Normalmente, os diversos fatos que originam alguns processos jurídicos de diferentes causas, inclusive as desapropriações, nem sempre são simples, e podem trazer dificuldade de entendimento ao juiz. Não se pode exigir que os juizes disponham de conhecimentos universais a ponto de examinar cientificamente tudo sobre a veracidade e as conseqüências de todos os fenômenos possíveis de figurar nos processos. Assim, o magistrado encontrando alguma dúvida de natureza técnico-científica poderá nomear um profissional de nível superior para o auxiliar através da apresentação de laudo pericial.

O laudo pericial é o relato das impressões constatadas pelo técnico, em torno do fato litigioso, por meio dos conhecimentos especiais de quem examinou vale pelas informações que contenha, não pela autoridade de quem o subscreveu, razão pela qual deve o perito indicar as razões em que se fundou para chegar às conclusões enunciadas em seu laudo. O conteúdo dos laudos elaborados por profissionais "peritos" facilita aos juizes formarem convicção para julgar as causas com indispensável segurança.

Conforme Espindula (2003) laudo é o escrito em que um perito ou um árbitro emite seu parecer e responde a todos os quesitos que lhe foram propostos pelo juiz e pelas partes interessadas. Parecer do louvado ou árbitro; peça escrita, fundamentada, em que os peritos expõem as observações e estudos que fizeram e consignam as conclusões da perícia.

Perícia, do latim peritia (habilidade, saber), na linguagem jurídica designa especialmente em sentido lato, a diligência realizada ou executada por peritos, a fim de que se esclareçam ou se evidenciem certos fatos. Significa, portanto, a pesquisa, o 
exame, a verificação a cerca da verdade ou da realidade de certos fatos, por pessoas de reconhecida habilidade ou experiência na matéria de que se trata (Ferreira, 1986).

Assim, o laudo pericial é uma peça técnica formal que apresenta o resultado de uma perícia. Neste laudo deve ser relatado tudo o que fora objeto dos exames levado a efeito pelos peritos. Ou seja, é um documento técnico-formal que exprime o resultado do trabalho do perito (Espindula 2003).

É importante salientar que um exame pericial é um trabalho de natureza eminentemente técnico-científico e deve ser o mais abrangente quanto possível. Segundo Espindula (2003), os peritos não devem se restringir ao que lhes foi perguntado ou requisitado, mas estarem sempre atentos para outros fatos que possam surgir no transcorrer de um exame. O laudo pericial é, portanto, o resultado final de um completo e detalhado trabalho técnico-científico, levado a efeito por peritos, cujo objetivo é o de subsidiar a Justiça em assuntos que ensejaram dúvidas no processo.

Entretanto, a Procuradora Geral do Estado de São Paulo vem deparando-se, desde o início de 1995, com inúmeros processos de pedidos de precatórios originários de ações de desapropriações, principalmente em áreas relacionadas com a Mata Atlântica, onde se situa o Parque Estadual da Serra do Mar. Nesses processos Schwenck Jr e Azevedo (1998) observaram que as indenizações requeridas apresentavam valores exorbitantes, incorrendo quase na totalidade dos casos, em supervalorização das áreas. A solicitação dessas indenizações, levaram Azevedo (1995) a concluir que vivemos épocas de excessos, pela qual passou-se dos "Parques de Papel", para os "Parques de Papel Moeda".

As avaliações da cobertura florestal natural, muitas delas, originando valores de indenizações milionárias, tem como destaque a elaboração de laudos periciais que atribuem valores distorcidos daqueles encontrados no mercado. De uma maneira geral, apresentam vícios de estrutura e elaboração, ignorando informações básicas como, dentre outras, procedimentos básicos de inventário florestal e estatística. 


\subsubsection{Direito e restrições ao uso da propriedade florestal}

As árvores que integram uma floresta têm grande utilidade para o homem e por isso são suscetíveis de apropriação. Assim, elas constituem um bem econômico e integram o patrimônio do proprietário da área. Conseqüentemente, as árvores formam um bem jurídico de natureza patrimonial. Sendo assim, as florestas se encontram entre os direitos patrimoniais (Magalhães 1990). O mesmo autor, considerando o Código Civil, afirma que dentro da sistemática desse Código, as florestas podem ser bens móveis, bens imóveis e bens fora do comércio. Quando pequenas mudas podem ser transportadas de um lugar para outro, sem qualquer alteração de sua forma ou substância, são bens móveis. Outra situação em que as árvores podem ser consideradas bens móveis, é aquela em que são plantadas com a finalidade de fornecer material lenhoso destinado ao consumo, sob forma de lenha ou matéria-prima industrial.

As árvores também podem ser consideradas bens imóveis, podendo se apresentar de três formas: a) quando são naturais e aderem ao solo são bens imóveis por natureza ou acessão natural; b) quando plantadas pelo homem, são bens imóveis por acessão artificial e, c) quando são separadas do solo momentaneamente, mas que se destinam ao replantio, são consideradas bens imóveis por acessão intelectual (Magalhães 1990).

Existem casos, entretanto, em que as árvores são consideradas bens fora de comércio, que são aqueles sobre os quais os particulares não podem exercer direito exclusivo ou que não podem alienar. Dessa maneira, como prevê o Código Florestal no Capítulo I, Artigo $1^{\circ}$, "As florestas, assim como as demais formações florísticas naturais, existentes no território nacional, são bens de interesse comum a todos os habitantes do País, exercendo-se os direitos de propriedade com as limitações que a legislação em geral e especialmente este código estabelecem.

O bem fora de comércio, segundo Magalhães (1990), se apresenta de duas formas: uma, quando ele não pode ser apropriado, como o ar, a luz, etc.; outra, quando a lei o tira de circulação por motivo relevante, como o caso dos bens públicos de uso comum do povo. No caso das árvores, quando elas formam um parque nacional ou quando são consideradas de preservação permanente (Código Florestal), são 
inapropriáveis e não podem ser alienadas. Nesse caso, argumenta o autor, são bens fora do comércio em face da legislação florestal e tem as características de inalienabilidade, impenhorabilidade e imprescritibilidade.

$\mathrm{Na}$ época em que foi elaborado o laudo pericial para auxiliar no processo de desapropriação da Estação Ecológica dos Caetetus (1977), estava em plena vigência o Código Florestal (Lei $\mathrm{n}^{\mathrm{o}}$ 4.771/65), que em seus artigos sacramentavam os direitos, porém impunham, juntamente com a Constituição Federal e o Estatuto da Terra, as limitações ao uso da propriedade florestal.

Além disso, mesmo antes da Constituição atual (promulgada em 1988), que determina em seu artigo 225, inciso VII, o dever do Poder Público em proteger a fauna e a flora, proíbe práticas que coloquem em risco sua função ecológica e considera patrimônio nacional a Floresta Amazônica Brasileira, a Mata Atlântica, a Serra do Mar, o Pantanal Mato-Grossense e a Zona Costeira, já estava em vigor outra lei específica, a Lei $\mathrm{n}^{\circ} 4.132$ de 10/09/62, que estabelecia, no inciso VII, do artigo $2^{\circ}$, o seguinte: Considera-se de interesse social: A proteção do solo e a preservação de cursos e mananciais de águas e de reservas florestais.

\subsubsection{Valoração ambiental}

Todas as sociedades dependem do ambiente em que vivem, entretanto, o valor dos recursos naturais é primordialmente mais implícito do que explícito e acaba sendo em alguns casos, um valor subjetivo. Valorar o ambiente é estimar o seu valor monetário em relação aos outros bens e serviços na economia. $\mathrm{O}$ cálculo da valoração deve conter informações sobre o uso ou estágio de degradação do meio ambiente e suas relações com o desenvolvimento econômico. A valoração ambiental é uma maneira de descrever a interação entre as atividades humanas e o meio ambiente, fornecendo referências para políticas de preservação ambiental, processos de danos causados a natureza, processos de desapropriações, e até mesmo a inserção das contas ambientais no sistema de contabilidade da nação, no contexto da globalização. No entanto, para se fazer uma 
análise da obtenção da valoração de qualquer área, é imprescindível entender o significados da palavra valor.

Valor, segundo Ferreira (1986) é a importância de determinada coisa, estabelecida ou arbitrada de antemão; é o equivalente justo em dinheiro, mercadoria, etc., especialmente de coisa que pode ser comprada ou vendida.

Apesar disso, para Marques e Comune (1995), o valor das relações entre a biodiversidade, que forma o valor total do meio ambiente não pode ser integralmente revelado por relações mercantis. Muitos dos seus componentes não são comercializados no mercado e os preços dos bens econômicos, não refletem o verdadeiro valor da totalidade dos recursos usados na sua produção. Nesse contexto, o problema prático com valoração econômica é, obter estimativas plausíveis a partir de situações reais onde não existem "mercados aparentes" ou existem "mercados muito imperfeitos".

Segundo Camargo (1995), as avaliações de natureza ambiental não se distinguem por sua ortodoxia, exigindo constante atualização e criatividade de modo a melhor enfocar os aspectos técnicos mais relevantes. A questão ambiental envolve, em geral, grandes áreas cujo detalhamento exige conhecimento especializado nos mais diversos campos.

As florestas naturais e plantadas fornecem bens e serviços de diversas naturezas que geram beneficios aos homens e aos ecossistemas, que utilizam diretamente seus produtos, e delas podem se beneficiar ou obter satisfação simplesmente pelo conhecimento da existência de ambientes florestais naturais preservadas. Os beneficios indiretos produzidos pelas florestas são denominados de várias formas, tais como: beneficios incomensuráveis, intangíveis, fugitivos, difusos, não comercializáveis no mercado, extra mercado ou não madeireiro, encaixando-se de um modo geral na definição de externalidades econômicas (Pedreira, 1990).

Mesmo não sendo normalmente utilizados em processos de desapropriação, torna-se conveniente, que sejam aqui apresentados os principais métodos de valoração ambiental, pois segundo Marques e Comune (1995), a maioria dos ativos ambientais não tem substitutos e a inexistência de sinalização de "preços" para seus serviços distorce a percepção dos agentes econômicos, introduzindo o mercado a falhas na sua alocação 
eficiente e evidenciando uma divergência entre os custos privados e sociais. Essa ausência de preços para os recursos ambientais trás um sério problema: o uso excessivo dos recursos, e isso, pode conduzir a uma criação "espontânea" desses mercados muito tardiamente, quando eles estiverem degradados num nível irreversível.

Os principais métodos de valoração econômica de bens e serviços ambientais, segundo Nogueira et al. (1998) são: método de valoração contingente (MVC), método Custos de viagem (MCV), método de preços hedômicos (MPH), método dose-resposta (MDR), método custo de reposição (MCR) e método de custos evitados (MCE). As características gerais de cada um deles serão descritas abaixo.

\subsection{Método de Valoração Contingente}

A idéia básica desse método é que as pessoas têm diferentes graus de preferências ou gostos por diferentes bens ou serviços e isso se manifesta quando elas vão ao mercado e pagam quantias específicas por eles. Ou seja, ao adquiri-los, elas expressam sua disposição a pagar (DiAP) ${ }^{1}$ por esses bens e serviços. São aplicados questionários diretos a uma amostra de consumidores. Este método é mais utilizado para a mensuração de: a) recursos de propriedade comum ou bens cuja excludibilidade do consumo não possa ser feita, tais como qualidade do ar ou da água; b) recursos de amenidades, tais como características paisagísticas, culturais, ecológicas, históricas ou singularidade e c) outras situações em que dados sobre preços de mercado estejam ausentes.

\subsection{Método Custos de Viagem}

\footnotetext{
${ }^{1}$ Para que não haja qualquer confusão com a abreviatura de "diâmetro à altura do peito" (DAP), reconhecida em trabalhos de levantamento florestal, utilizou-se para o termo "disposição a pagar", a abreviatura DiAP, adaptando assim aquela utilizada pelo autor (Nogueira et al. (1998).
} 
Hanley e Spash (1993), citados por Nogueira et al. 1998, afirmam que provavelmente essa é a mais antiga técnica de valoração de bens não transacionados no mercado, remontando suas origens a 1947. A idéia desse método é que os gastos efetuados pelas famílias para se deslocarem a um lugar, geralmente para recreação, podem ser utilizados como uma aproximação dos benefícios proporcionados por essa recreação. Ou seja, utiliza-se o comportamento do consumidor em mercados relacionados para valorar bens ambientais que não têm mercado explícito, incluindo despesas com a viagem e preparativos. Este método tem aplicação restrita à valoração de características peculiares aos locais e à valoração do tempo.

\subsection{Método de Preços Hedômicos}

É um dos métodos mais utilizados e procura avaliar que, quando uma pessoa vai ao mercado imobiliário comprar um imóvel, ela considera também as suas características locacional e ambiental para fazer a sua escolha. Ao tomar a sua decisão, ela está, de certa forma, valorando essas peculiaridades do imóvel. Usa-se os dados dos valores de propriedades residenciais para estimar os benefícios de mudanças nos parâmetros de qualidade ambiental. É um método aplicado apenas nos casos em que os atributos ambientais possam ser capitalizados nos preços de residências ou imóveis.

\subsection{Método Dose-Resposta}

Este método procura estabelecer um relacionamento entre variáveis que retratam a qualidade ambiental e o nível do produto de mercado, quer em termos de quantidade ou qualidade. Trata a qualidade ambiental como um fator de produção. As aplicações mais comuns estão relacionadas aos impactos da qualidade do ar sobre a produção agrícola e aos impactos da poluição sobre a pesca. 


\subsection{Método Custo Reposição}

Este método se baseia no custo de reposição ou restauração de um bem danificado e entende esse custo como uma medida do seu benefício. É freqüentemente utilizado como uma medida do dano causado. A operacionalização desse método é feita pela agregação dos gastos efetuados na reparação dos efeitos negativos provocados por algum distúrbio na qualidade ambiental de um recurso utilizado numa função de produção.

\subsection{Método de Custos Evitados}

Este método considera que a motivação para os gastos é a necessidade de substituir por outros insumos (ou melhorar os existentes) devido à mudança na qualidade do recurso anteriormente utilizado no processo produtivo. As aplicações mais comuns desse método estão na mortalidade e morbidade humanas e estudos relacionados com poluição e suas implicações sobre a saúde humana.

Cada método apresenta uma eficiência específica para determinado caso, mas a maior dificuldade de todos se encontra na estimativa de valores relacionados à própria existência do recurso ambiental, sem considerar sua utilidade atual ou futura (Maia 2002). A fundamentação teórica dos métodos apresentados acima, os vieses estimativos e as orientações gerais para seus usos, além de um roteiro indicativo para a escolha do método mais apropriado de acordo com o objetivo da mensuração, são apresentados com mais detalhes por (Manual de valoração ambiental - IBAMA).

\subsubsection{Legislação Ambiental}

Desde o Código Florestal de 1934 o exercício do direito de propriedade ficou limitado ao interesse social, considerando que o proprietário não pode utilizar a floresta de maneira predatória, sem o aproveitamento racional e adequado. As características 
específicas da floresta, tais como a composição florística, a estrutura da vegetação e o estádio sussecional, devem ser levadas em conta, uma vez que, pela legislação florestal, nem toda a área da propriedade poderá ser explorada da mesma maneira.

A legislação pertinente à propriedade florestal regulamenta as condições de uso dessas propriedades, bem como as normas para a supressão de vegetação das mesmas. Dessa forma, estudos que objetivem compor o preço dessas propriedades e que façam o levantamento do potencial de madeira a ser retirado, devem respeitar as restrições da lei, sob pena de acarretar em superestimação do valor.

\subsubsection{Código Florestal}

No Código Florestal (Lei $\mathrm{n}^{0}$ 4.771/65) são encontrados os conceitos mais importantes e as restrições que devem ser respeitadas quando do uso da propriedade florestal. $\mathrm{O}$ artigo $2^{\circ}$ do referido Código caracteriza as áreas de preservação permanente da seguinte forma "Consideram-se de preservação permanente, pelo só efeito desta Lei, as florestas e demais formas de vegetação natural situadas":

a) ao longo dos rios ou de qualquer curso d'água desde o seu nível mais alto em faixa marginal cuja largura mínima seja:

1 - de $30 \mathrm{~m}$ (trinta metros) para os cursos d'água de menos de $10 \mathrm{~m}$ (dez metros) de largura;

2 - de $50 \mathrm{~m}$ (cinqüenta metros) para os cursos d'água que tenham de 10 (dez) a $50 \mathrm{~m}$ (cinqüenta metros) de largura;

3 - de $100 \mathrm{~m}$ (cem metros) para os cursos d'água que tenham de 50 (cinqüenta) a $200 \mathrm{~m}$ (duzentos metros) de largura;

4 - de $200 \mathrm{~m}$ (duzentos metros) para os cursos d'água que tenham de 200 (duzentos) a $600 \mathrm{~m}$ (seiscentos metros) de largura;

5 - de $500 \mathrm{~m}$ (quinhentos metros) para os cursos d'água que tenham largura superior a $600 \mathrm{~m}$ (seiscentos metros).

b) ao redor das lagoas, lagos ou reservatórios d'água naturais ou artificiais; 
c) nas nascentes, ainda que intermitentes e nos chamados "olhos d'água", qualquer que seja a sua situação topográfica, num raio mínimo de $50 \mathrm{~m}$ (cinqüienta metros) de largura;

d) no topo de morros, montes, montanhas e serras;

e) nas encostas ou partes destas, com declividade superior a 45 , equivalente a $100 \%$ na linha de maior declive;

f) nas restingas, como fixadoras de dunas ou estabilizadoras de mangues;

g) nas bordas dos tabuleiros ou chapadas, a partir da linha de ruptura do relevo, em faixa nunca inferior a $100 \mathrm{~m}$ (cem metros) em projeções horizontais;

h) em altitude superior a $1.800 \mathrm{~m}$ (mil e oitocentos metros), qualquer que seja a vegetação.

O Art. $3^{\circ}$ considera também de preservação permanente, as áreas de florestas e demais formas de vegetação natural, declaradas por ato público e destinadas:

a) a atenuar a erosão das terras;

b) a fixar as dunas;

c) a formar faixas de proteção ao longo de rodovias e ferrovias;

d) a auxiliar a defesa do território nacional a critério das autoridades militares;

e) a proteger sítios de excepcional beleza ou de valor científico ou histórico;

f) a asilar exemplares da fauna ou flora ameaçados de extinção;

g) a manter o ambiente necessário à vida das populações silvícolas;

h) a assegurar condições de bem-estar público

$\mathrm{O}$ parágrafo $1^{\circ}$ deste Artigo aborda as condições que restringem o corte da vegetação florestal, afirmando que: "a supressão total ou parcial de florestas de preservação permanente só será admitida com prévia autorização do Poder Executivo Federal, quando for necessária à execução de obras, planos, atividades ou projetos de utilidade pública ou interesse social. 
As áreas de preservação permanente, pelo que se pode observar no exposto acima, são praticamente intocáveis. Entretanto, existem outros artigos, que serão apresentados a seguir, que tratam das possibilidades de manejo de florestas em propriedades privadas, fornecendo regulamentações. As informações contidas nestes artigos devem ser efetivamente consideradas, quando da elaboração do relatório final do laudo de desapropriação.

Art. $7^{\circ}$ - Qualquer árvore poderá ser declarada imune de corte, mediante ato do Poder Público, por motivo de sua localização, raridade, beleza ou condição de porta-sementes.

Art. 10 - Não é permitida a derrubada de florestas, situadas em áreas de inclinação entre 25 a 45 graus, só sendo nelas tolerada a extração de toras, quando em regime de utilização racional, que vise a rendimentos permanentes.

Art. 12 - Nas florestas plantadas, não consideradas de preservação permanente, é livre a extração de lenha e demais produtos florestais ou a fabricação de carvão. Nas demais florestas, dependerá de norma estabelecida em ato do Poder Federal ou Estadual, em obediência a prescrições ditadas pela técnica e às peculiaridades locais.

Art. 14 - Além dos preceitos gerais a que está sujeita a utilização das florestas, o Poder Público Federal ou Estadual poderá:

a) prescrever outras normas que atendam às peculiaridades locais;

b) proibir ou limitar o corte das espécies vegetais consideradas em via de extinção, delimitando as áreas compreendidas no ato, fazendo depender, nessas áreas, de licença prévia o corte de outras espécies;

c) ampliar o registro de pessoas fisicas ou jurídicas que se dediquem à extração, indústria e comércio de produtos ou subprodutos florestais. 
Art. 16 - As florestas de domínio privado, não sujeitas ao regime de utilização limitada e ressalvadas as de preservação permanente, previstas nos artigos 2 e 3 desta lei, são suscetíveis de exploração, obedecidas as seguintes restrições:

a) nas regiões Leste Meridional, Sul e Centro-Oeste, esta na parte sul, as derrubadas de florestas nativas, primitivas ou regeneradas, só serão permitidas, desde que seja, em qualquer caso, respeitado o limite mínimo de $20 \%$ da área de cada propriedade com cobertura arbórea localizada, a critério da autoridade competente;

b) nas regiões citadas na letra anterior, nas áreas já desbravadas e previamente delimitadas pela autoridade competente, ficam proibidas as derrubadas de florestas primitivas, quando feitas para ocupação do solo com cultura e pastagens, permitindo-se, nesses casos, apenas a extração de árvores para produção de madeira. Nas áreas ainda incultas, sujeitas a formas de desbravamento, as derrubadas de florestas primitivas, nos trabalhos de instalação de novas propriedades agrícolas, só serão toleradas até o máximo de $30 \%$ da área da propriedade;

c) na região Sul as áreas atualmente revestidas de formações florestais em que ocorre o pinheiro brasileiro, "Araucaria angustifolia" (Bert. O.Ktze), não poderão ser desflorestadas de forma a provocar a eliminação permanente das florestas, tolerando-se, somente a exploração racional destas, observadas as prescrições ditadas pela técnica, com a garantia de permanência dos maciços em boas condições de desenvolvimento e produção;

d) nas regiões Nordeste e Leste Setentrional, inclusive nos Estados do Maranhão e Piauí, o corte de árvores e a exploração de florestas só será permitida com observância de normas técnicas a serem estabelecidas por ato do Poder Público, na forma do Art. 15.

$\S 1^{\circ}$ - Nas propriedades rurais, compreendidas na alínea "a" deste artigo, com área entre 20 (vinte) a 50 ha (cinqüenta hectares), computar-se-ão, para efeito de fixação do limite percentual, além da cobertura florestal de qualquer natureza, os maciços de porte arbóreo, sejam frutíferos, ornamentais ou industriais. 
$\S 2^{\circ}$ - A reserva legal, assim entendida a área de, no mínimo, $20 \%$ (vinte por cento) de cada propriedade, onde não é permitido o corte raso, deverá ser averbada à margem da inscrição de matrícula do imóvel, no registro de imóveis competente, sendo vedada a alteração de sua destinação, nos casos de transmissão, a qualquer título, ou de desmembramento da área.

Art. 19 - A exploração de florestas e de formações sucessoras, tanto de domínio público como de domínio privado, dependerá de aprovação prévia do Instituto Brasileiro do Meio Ambiente e dos Recursos Naturais Renováveis - IBAMA, bem como da adoção de técnicas de condução, exploração, reposição florestal e manejo, compatíveis com os variados ecossistemas que a cobertura arbórea forme.

A apresentação dos artigos mencionados acima tem o objetivo de mostrar a importância da legislação na elaboração do laudo pericial. Logicamente, compete ao perito reportar-se a legislação existente e considerá-la em todos os sentidos, quando estiver compondo o preço final da propriedade. É muito importante que no seu relatório final, o perito informe ao juiz, a estratificação da gleba, de acordo com o enquadramento que a lei prevê.

\subsubsection{Conteúdo do laudo}

Considerando o exposto acima, deverá o perito fornecer outras informações relevantes como: a existência de cursos d'água na propriedade, a largura média e os respectivos comprimentos; existência de nascentes e a quantidade delas; descrição detalhada do relevo da propriedade, quantificando as áreas de encosta e suas respectivas declividades, topos de morros, etc. As áreas com restrições legais (Art. $2^{\circ}$ e $3^{\circ}$ ) devem receber tratamento diferenciado quando da sua valoração, uma vez que não se pode admitir que tenham o seu valor equiparado com áreas produtivas.

Restrições técnicas também precisam ser consideradas. Assim, além do mapeamento da cobertura vegetal da propriedade, que viabilizará entre outras coisas o 
delineamento e a intensidade de amostragem do inventário florestal, poderá também, ser feito o levantamento das características de fragilidade do solo, com o objetivo de fornecer subsídios para o atendimento do Art. $3^{\mathrm{a}}$, na sua alínea "a". 


\section{MATERIAL E MÉTODOS}

\subsection{Estação Ecológica dos Caetetus - Área de estudo}

O presente trabalho foi desenvolvido na Estação Ecológica dos Caetetus, Unidade de Conservação administrada pelo Instituto Florestal, órgão da Secretaria de Meio Ambiente do Estado de São Paulo.

O MINISTÉRIO DO MEIO AMBIENTE (2000), analisando ações prioritárias para conservação da biodiversidade na mata atlântica e nos campos sulinos, classifica a Estação Ecológica dos Caetetus como sendo: área de alta importância biológica, ao considerar a conservação de aves e mamíferos e de extrema importância biológica à conservação de répteis e anfibios. O referido relatório também classifica a área como de alta pressão antrópica e ressalta o fato de ser uma área de extrema importância biológica para a conservação da flora, com especial atributo para conservação in situ de germoplasma de espécies nativas, além de recomendar maiores investigações para que seja compreendido o potencial de conectividade dessa área, com outros fragmentos florestais da região. Estas classificações salientam ainda mais a importância dessa Unidade de Conservação,

\subsubsection{Localização e Histórico}

A Estação Ecológica dos Caetetus (Figura 1) localiza-se a sudoeste da cidade de Gália, próximo ao $\mathrm{Km} 186$ da rodovia vicinal SP 331 (Gália/Garça - Ourinhos), entre as coordenadas geográficas $22^{\circ} 41^{\prime}$ a $22^{\circ} 46^{\prime} \mathrm{S}$ e $49^{\circ} 10^{\prime}$ a $49^{\circ} 16^{\prime} \mathrm{W}$, numa área de 
2.176,10ha nos municípios de Gália e Alvinlândia, região Centro-Oeste do Estado de São Paulo Tabanez et al. (no prelo).

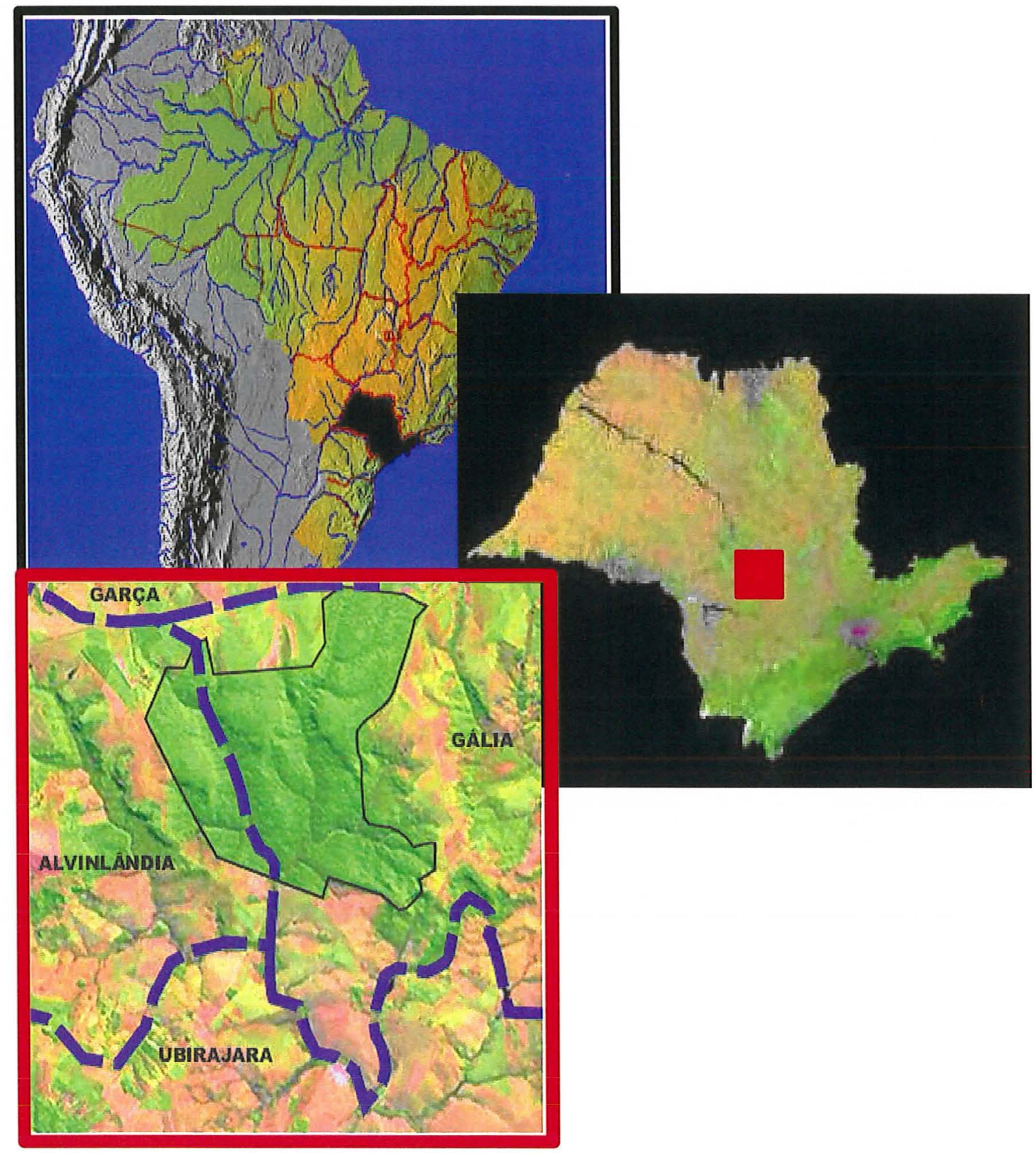

Figura 1 - Localização da estação Ecológica dos Caetetus 
A Estação Ecológica do Caetetus pertenceu à Fazenda Paraíso, uma das mais antigas fazendas da região, de propriedade do Sr. Olavo Amaral Ferraz.

A área está preservada na forma de Unidade de Conservação desde 1976, quando foi desapropriada pelo então governador do Estado Sr. Paulo Egídio Martins, com o objetivo de constituir uma Reserva Florestal de Preservação de Recursos Naturais, através do Decreto $\mathrm{n}^{\mathbf{0}}$ 8346. Foi transformada em Estação Ecológica, em 06 de fevereiro de 1987, com a justificativa de servir como área reservada para a realização de pesquisas em ecologia, para a proteção do meio ambiente natural e ao desenvolvimento da educação conservacionista.

A área total constante dos dois decretos correspondentes à unidade, é 2.178,84ha. Porém, através de levantamento topográfico, objetivando a divisão amigável das glebas de terra que passaram a pertencer aos sucessores de Olavo Amaral Ferraz, obteve-se precisamente, mediante cálculo analítico dos perímetros correspondentes a cada fração da propriedade, que a superfície da estação é de $2.176,10$ ha. No que tange à ação de desapropriação indireta, após análise conjunta entre o Instituto Florestal e a Procuradoria Geral do Estado deliberou-se pelo pagamento da área menor, isto é, aquela obtida em função de levantamento topográfico.

Todas as informações aqui apresentadas sobre o histórico da área foram extraídas do Plano de Manejo da Estação Ecológica dos Caetetus, documento que se encontra mo prelo.

\subsubsection{Clima, Solo e Vegetação}

A região apresenta duas estações nitidamente marcadas: verão e inverno diferenciado principalmente pela deficiência de umidade nos meses de inverno. Segundo Tabanez et al. (no prelo) o clima enquadra-se no tipo Cwa, conforme a classificação de Köppen, apresentando-se quente e com precipitação anual ao redor de $1400 \mathrm{~mm}$, concentrada nos meses de verão. A temperatura média anual é de $21^{\circ} \mathrm{C}\left(\max =36^{\circ} \mathrm{C}\right.$ e $\min =13^{\circ} \mathrm{C}$ ). 
A estação Ecológica dos Caetetus encontra-se no Planalto Ocidental sobre arenitos da Formação Marília e Adamantina com cimento calcáreo, predominando os latossolos de textura média nos topos e os podzólicos abruptos nas vertentes (Mattos et al. 1996). O planalto Central compõe a região do estado de relevo mais homogêneo, conseqüência do domínio do Grupo Bauru, sendo os seus depósitos, predominantemente, quaternários. Abrange cerca de 50\% do território paulista (IPT, 1981).

Tabanez et al. (no prelo), constataram que ocorrem na Estação Ecológica do Caetetus principalmente as seguintes classes de solos: Latossolo Vermelho-Amarelo Podzólico; Podzólico Vermelho-Amarelo, Glei Pouco Húmido; Solo Litólico; Regossolo e Solos Aluviais.

A vegetação da EEC enquadra-se na categoria de floresta estacional semidecidual submontana. A ocorrência desta categoria vegetacional vai desde o Espírito Santo e sul da Bahia até o Rio de Janeiro, Minas Gerais, São Paulo, norte, e sudoeste do Paraná e sul do Mato Groso do Sul. O gênero que a caracteriza, principalmente no planalto paranaense e no oeste do Estado de São Paulo, é Aspidosperma, com seu ecótipo A. polyneuron - a peroba-rosa (IBGE 1992) Segundo Rizzini (1976), esta formação ocorre em forma de manchas, principalmente na região do cerrado do Brasil central.

\subsection{3 Área do experime nto}

O local específico escolhido para a realização do estudo apresenta altitude média em torno de 550 metros, com pouca declividade. Localiza-se entre o Córrego do Barreiro e o Córrego Comprido (Figura 2), onde, segundo informações de moradores da região, nunca ocorreu extração seletiva de madeira. Isto foi confirmado durante o período de medição e plaqueamento das árvores, quando não se observou nenhum vestígio de perturbação antrópica. Somente na noite do de 19 para 20 de maio de 2002, observou-se uma perturbação mais intensa, quando chuvas torrenciais acompanhadas de rajadas de vento muito forte provocaram a quebra e tombamento de diversas árvores. 
Tabanez et al. (no prelo) enquadraram a vegetação da área de amostragem do presente trabalho, em duas fisionomias predominantes: a) vegetação arbórea de porte alto e denso, com árvores emergentes e de baixa deciduidade, mata bem preservada, predomina nas altas escarpas e bordas do planalto; b)vegetação arbórea de porte alto e denso, não apresenta deciduidade, bem preservada com pouca ou nenhuma perturbação antrópica; ocupa as baixas vertentes e os fundos de vales.

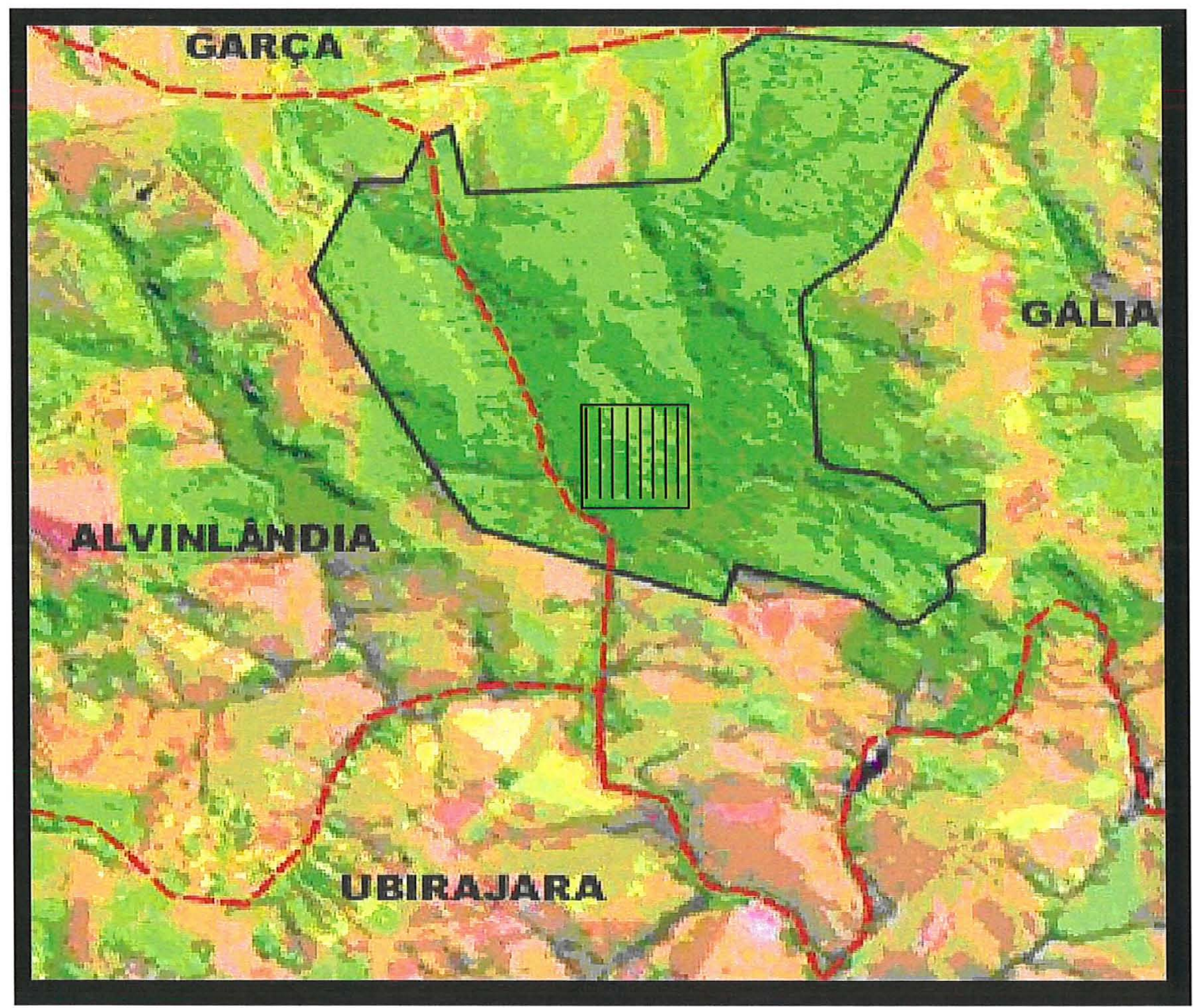

Figura 2 - Localização da grade de amostragem na Estação Ecológica dos Caetetus 


\subsection{Métodos de amostragem empregados}

Os dados no presente trabalho foram obtidos com a utilização dos dois métodos de amostragem fitossociológicas mais usuais no Estado de São Paulo: método de quadrante (Cottan \& Curtis, 1956) e método de parcelas (Chapman, 1976).

\subsection{Procedimentos de campo}

\subsubsection{Instalação das Parcelas}

Numa área de abrangência correspondente a 64 hectares, foi estabelecida uma malha (grade) de 64 pontos sistematicamente distribuídos a cada 100 metros. Cada ponto devidamente marcado em campo, com uma haste de PVC, foi considerado como o centro de uma parcela primária de $10 \times 90 \mathrm{~m}\left(900 \mathrm{~m}^{2}\right)$, totalizando uma área de amostragem de 5,76ha. Cada parcela primária foi subdividida em parcelas secundárias de $10 \times 10 \mathrm{~m}\left(100 \mathrm{~m}^{2}\right)$. A distância entre as parcelas primárias foi de $10 \mathrm{~m}$ e entre cada linha, 100 metros. (Fig 3). A demarcação das parcelas primárias foi feita seguindo uma orientação perpendicular à "trilha 12" que corta a área no sentido Leste-Oeste. Esta trilha é utilizada pela vigilância da unidade e por pesquisadores que estudam o comportamento de grandes animais silvestres que ali vivem. Para a orientação das linhas, utilizourse de uma bússola e três estacas de ferro (balizas), para o fornecimento do azimute. A distância entre as linhas e entre os pontos foi obtida através de trena eletrônica (Forestor Vertex ).

Cada linha recebeu a denominação de uma letra, e cada parcela primária um número seqüencial de 1 a 8 , conforme a posição na linha (Figura 3).

Em cada uma das parcelas primárias foram amostrados todos os indivíduos arbóreo-arbustivos, vivos ou mortos em pé, com DAP igual ou superior a $5 \mathrm{~cm}$. Segundo Rodrigues (1989), esse diâmetro mínimo é satisfatório por incluir tanto os indivíduos arbóreos de grande porte, como aqueles de menor porte, que são importantes na composição de sub-bosque florestal. Os indivíduos que perfilharam acima do solo e 
abaixo da altura do peito $(1,30 \mathrm{~m})$, foram incluídos quando pelo menos uma das ramificações se enquadrou no critério de inclusão de DAP, sendo então anotado o DAP de todas as ramificações, para o cálculo da área basal. As árvores mortas, porém, ainda em pé, foram consideradas somente quanto ao número, sem distinção de espécie, nem utilizadas para estimativa dos parâmetros fitossociológicos. Os indivíduos foram marcados com plaquetas de alumínio numeradas.

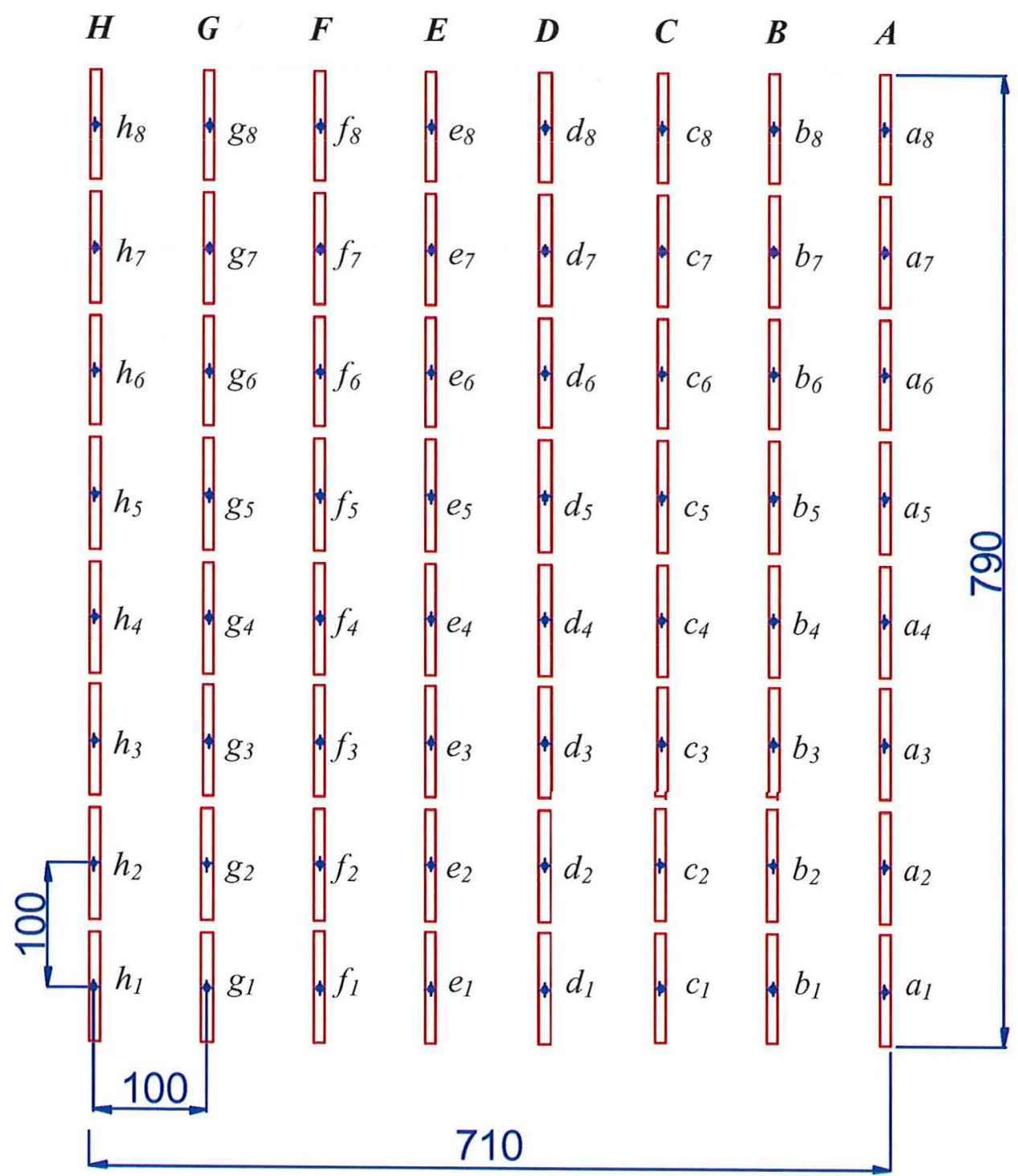

Figura 3 - Desenho esquemático da grade de amostragem 
A identificação das espécies presentes foi realizada a partir da descrição do material vegetativo e, sempre que possível, também, reprodutivo, coletado no local. Para isso, utilizourse da chave dicotômica, baseada apenas em caracteres vegetativos conforme Franco (2002), e comparação com plantas herborizadas existentes no Herbário D. Bento Pickel do Instituto Florestal, além da colaboração de especialistas pertencentes a esta Instituição. Os materiais dos indivíduos que apresentaram estruturas férteis foram preparados de acordo com método usual (Fidalgo e Bononi 1989) e depositados no Herbário D. Bento Pickel, do Instituto Florestal (SPSF). Adotou-se o sistema de classificação de Cronquist (1981).

Além da medição do DAP e da identificação botânica, cada indivíduo vivo foi classificado quanto à sua posição na estrutura vertical, através de separação visual, onde foram consideradas as seguintes posições: $\mathrm{I}=$ sub-bosque; $\mathrm{M}=$ estrato médio; $\mathrm{D}=$ Dossel e $\mathrm{E}=$ emergente.

\subsubsection{Instalação dos quadrantes}

Para a amostragem através do método de quadrantes, foram instalados 320 pontos, distribuídos sistematicamente na área da grade descrita no item anterior distantes 20 metros entre si. O método de quadrantes, segundo Rodrigues (1988), é o método de distância usado com mais freqüência em levantamentos fitossociológicos. Consiste no estabelecimento de pontos dentro da formação a ser estudada, que servirão de centro de círculos, divididos em quatro quadrantes.

No presente estudo, os pontos foram distribuídos de maneira que, em cada parcela primária, ocorressem 5 pontos, alocados sobre a trilha, da seguinte maneira: no limite da parcela secundária 1 e nas junção das parcelas secundárias 2 e 3, 4 e 5,6 e 7 e 8 e 9 conforme é mostrado na Figura 4. Assim, para cada parcela primária correspondeu 18 indivíduos do método de quadrantes. Os indivíduos relativos a dois quadrantes do ponto localizado na borda da parcela primária foram amostrados fora da mesma. Dessa 
maneira, dos 1280 indivíduos amostrados nos 320 pontos quadrantes, 128 não são coincidentes com a área das parcelas.

O diâmetro mínimo, a marcação, e o enquadramento na estratificação vertical dos indivíduos seguiu as mesmas especificações do item anterior.

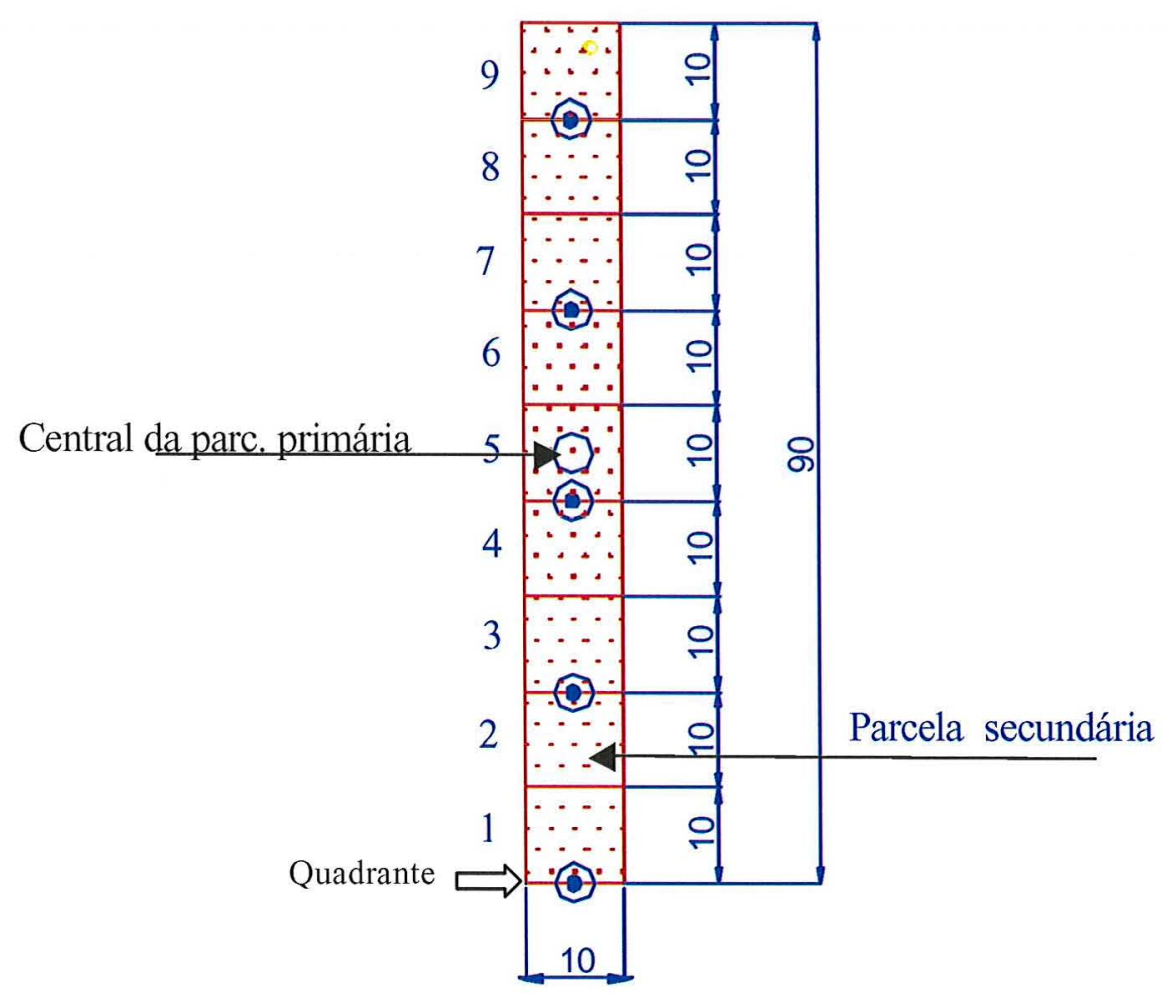

Figura 4 - Desenho esquemático de uma parcela primária, dividida em parcelas secundárias, com a localização dos pontos quadrantes

\subsection{Grupos Ecológicos}

Para a classificação das espécies segundo os grupos ecológicos, foram utilizados os critérios adotados por Durigan e Leitão-Filho (1995), com a seguinte abordagem: 
Pioneiras - espécies de ciclo de vida curtos, que só germinam e se desenvolvem à plena luz;

Não pioneiras heliófitas - espécies de ciclo de vida longo, que podem germinar na sombra, mas exigem luz solar direta para se desenvolver;

Não pioneiras umbrófilas quando jovens - espécies de ciclo muito longo, que germinam e se desenvolvem à sombra, mas ocupam o estrato superior da floresta quando adultas, comportando-se então como heliófitas;

Não pioneiras sempre umbrófilas -- espécies que germinam e se desenvolvem sob dossel durante todo o ciclo de vida

A proporção dessas espécies e do número de ndivíduos de cada uma delas na estrutura horizontal e estratificação vertical pode indicar o estágio de maturidade da floresta. Esta informação também deve constar do relatório do perito, uma vez que não se concebe a idéia de desapropriação com fins de preservação ambiental, de áreas que apresentem apenas florestas em estádio inicial de sucessão.

\subsection{Parâmetros fitossociológicos}

Para a estimativa dos parâmetros fitossociológicos foram utilizadas as seguintes expressões (Müeller-Dombois \& Ellenber, 1974):

DTA (método de parcelas) $=\mathrm{N} / \mathrm{A}$

DAi (método de parcelas) $=$ ni $/ \mathrm{A}$

DAi (método dos quadrantes) $=$ ni / N . DTA

$\mathrm{AM}$ (método de quadrantes) $=(\mathrm{di} / \mathrm{N})^{2}$

DRi (método de parcelas $)=n i / N .100$

DRi (método de quadrantes) $=100$. DAi / ÓDA

$\mathrm{FAi}=\mathrm{pi} / \mathrm{PT} .100$

$\mathrm{FRi}=\mathrm{FAi} / \mathrm{FAT} .100$ 
$\mathrm{FAT}=$ ÓFAi

DoTA $=$ ABT $/ \mathrm{A}$

$\mathrm{ABmi}=\mathrm{ABi} / \mathbf{n i}$

$A b i=\left(P I . d^{2}\right) / 4$

$\mathrm{ABi}=$ ÓAbi

$\mathrm{ABT}=$ ÓABi

DoAi $=$ DAi.$A B m i$

DoRi $=$ ABi / ABT .100

$\mathrm{IVI} i=\mathrm{DR} i+\mathrm{FRi}+\mathrm{DoR} i$

$\mathrm{IVCi}=\mathrm{DRi}+\mathrm{DoRi}$

Onde:

DTA = densidade absoluta total ou Densidade Total por Área. Estima o número total de indivíduos, por unidade de área, independente da espécie. A unidade de área é considerada lha ou $10.000 \mathrm{~m}^{2}$. É expressa em $\mathrm{n}^{\mathrm{o}}$ de indivíduos por ha (hectare);

$\mathbf{N}=$ número total de indivíduos amostrados, independentes da espécie;

$\mathrm{U}=$ unidade de área $\left(\right.$ lha $\left.=10.000 \mathrm{~m}^{2}\right) ;$

$\mathbf{A}=$ área amostrada (ha.);

$\mathbf{A M}=$ área média;

di = distância média geométrica corrigida. A distância corrigida refere-se à soma da distância individual obtida para cada árvore acrescida do raio de seu diâmetro;

Dai = densidade absoluta da espécie i. É o número de indivíduos de uma dada espécie, por unidade de área. É também expressa em indivíduo por ha;

DRi = densidade relativa da espécie i. Expressa, em percentagem, é a relação entre o número de indivíduos de uma determinada espécie e o número total de indivíduos amostrados. A densidade relativa dá uma idéia do tamanho das populações na área estudada, mas não do tamanho dos indivíduos, nem da forma 
como estão distribuídos no espaço, embora o padrão espacial da população influa nos valores da densidade;

$\mathbf{n i}=$ número de indivíduos amostrados da espécie $\mathbf{i}$;

FAi = freqüência absoluta da espécie i. É a percentagem de unidades de amostragem em que a espécie $\mathrm{i}$ ocorreu, em relação ao total de unidades amostradas;

FAT = freqüência absoluta total (soma das freqüências absolutas de todas as espécies amostradas);

pi = número de unidades de amostragem com a presença da espécie $\mathrm{i}$;

PT = número total de unidades de amostragem;

FRi = freqüência relativa da espécie i. Expressa, em percentagem, é a relação entre a freqüência absoluta da espécie $i$, com as freqüências absolutas de todas as espécies amostradas. A freqüência relativa determina a regularidade da distribuição de cada espécie sobre o terreno. Os valores de freqüência estimam a probabilidade de encontrar a espécie i numa unidade de amostragem lançada ao acaso na formação vegetal. Depende da abundância da população e é influenciada pelo padrão de distribuição espacial;

DoAi = dominância absoluta da espécie i. Dá a taxa de ocupação do ambiente pelos individuos da espécie $\mathrm{i}$, por unidade de área. É expressa $\mathrm{em} \mathrm{m}^{2} / \mathrm{ha}$;

DoRi = dominância relativa da espécie i. Expressa, em percentagem, a área ocupada pelos indivíduos da espécie $\mathrm{i}$, em relação à área total ocupada pelos indivíduos de todas as espécie;

DoTA = dominância absoluta total. Estima o total de área ocupada pela vegetação, por unidade de área. É expressa $\mathrm{em} \mathrm{m}^{2} / \mathrm{ha}$;

$\mathbf{A B i}=$ área basal total da espécie $\mathrm{i}\left(\mathrm{m}^{2}\right)$;

$\mathbf{A B m i}=$ área basal média da espécie i $\left(\mathrm{m}^{2}\right)$;

ABT = área basal total de todas as espécies amostradas $\left(\mathrm{m}^{2}\right)$;

Abi = área basal de um indivíduo da espécie i $\left(\mathrm{m}^{2}\right)$;

$\mathbf{d}=$ diâmetro à altura do peito; 
IVIi = índice do valor de importância da espécie i. Trata-se de um índice constituído pela soma dos valores relativos de frequiência, densidade e dominância, podendo variar até ao máximo de 300 ;

IVCi $=$ índice do valor de cobertura da espécie i.Trata-se de um índice constituído pela soma dos parâmetros relativos, excluindo-se a freqüência, podendo variar até 200.

\subsubsection{Estimativa da densidade para o método dos quadrantes}

A estimativa da densidade no método de quadrantes foi baseada no estimador proposto por Pollard (1971), de acordo com Krebs (1999). A densidade da floresta foi obtida por:

$$
\mathrm{N}_{\mathrm{p}}=10.000[4(4 \mathrm{n}-1)] /\left[\pi \Sigma \mathrm{r}_{\mathrm{ij}}{ }^{2}\right]
$$

Onde:

$\mathbf{r}_{\mathrm{ij}}$ é a distância do ponto $\mathrm{i}(\mathrm{i}=1,2,3, \ldots \ldots . ., 320)$ à árvore mais próxima no quadrante $\mathrm{j}(\mathrm{j}=1,2,3,4)$;

O erro padrão da estimativa da densidade foi obtida por:

$$
\left[\mathbf{N}_{\mathrm{p}} /\left(\mathbf{4 n - 2 ) ] ^ { 0 , 5 }}\right.\right.
$$

Os limites do intervalo de confiança de $95 \%$ foram obtidos segundo Seber (1982), citado por Krebs, (1999), pela expressão:

Limite Inferior: $10.000\left\{\left[(16 \mathrm{n}-1)^{0,5}-1,96\right] /\left[\overline{\left.\left[\pi \mathrm{r}_{i j}{ }^{2}\right]^{0,5}\right\}^{2}}\right.\right.$
Limite Supérior: $10.000\left\{\left[(16 \mathrm{n}-1)^{0,5}+1,96\right] /\left[\pi \Sigma \mathrm{r}_{\mathrm{ij}}{ }^{2}\right]^{0,5}\right\}^{2}$ 


\subsection{Qualificação da madeira}

Para a qualificação da madeira, tomou-se como base classes comerciais, as quais são definidas em função das características tecnológicas de cada espécie. Assim, para este estudo, considerou-se as classes I, II e III, e o que não se enquadrou nessa classificação foi considerada lenha.

As madeiras de classe I - de alto valor comercial - podem ser utilizadas em: construção civil e naval, marcenaria de luxo, móveis finos, obras externas e tabuados em geral.

As madeiras de classe II - com valor comercial médio - se prestam para peças curvas, formas de sapato, construções rurais, vigamentos, tacos de assoalho, cabos de ferramentas, postes, carroçaria e vagões, etc.

Quanto às madeiras de classe III - de baixo valor comercial - podem ser utilizadas na fabricação de lápis, tamancos, instrumentos musicais e caixotarias finas.

\subsection{Volume}

Para o ajuste da equação de volume utilizou-se dados de uma floresta estacional semidecidual montada de Minas Gerais (Scolforo et al., 1994) em que foi medido o DAP e cubado o volume comercial com casca de árvores. Foram testados quatro modelos de equação de volume local, isto é, do volume em função do DAP:

$$
\begin{aligned}
& \text { Modelo 1: } v_{i}=\beta_{0}+\beta_{1} d_{i}^{2}+\varepsilon_{i} \\
& \text { Modelo 2: } v_{i}=\beta_{0}+\beta_{1} d_{i}+\beta_{2} d_{i}^{2}+\varepsilon_{i} \\
& \text { Modelo 3: } \log \left(v_{i}\right)=\beta_{0}+\beta_{1} \log \left(d_{i}\right)+\varepsilon_{i}
\end{aligned}
$$


Modelo 4: $\log \left(v_{i}\right)=\beta_{0}+\beta_{1} \log \left(d_{i}\right)+\beta_{2} \log ^{2}\left(d_{i}\right)+\varepsilon_{i}$

Onde:

$\mathbf{v}_{\mathbf{i}}$ é o volume comercial com casca $\left(\mathrm{m}^{3}\right)$;

$\mathbf{d}_{\mathbf{i}}$ é o DAP (diâmetro à altura do peito $(\mathrm{cm})$;

$\boldsymbol{\beta}_{\mathrm{k}}$ são os coeficientes de regressão, estimados por quadrados mínimos;

$\boldsymbol{\varepsilon}_{\mathbf{i}}$ são os erros aleatórios, que se assume como independentes e identicamente distribuídos segundo a distribuição Normal, com média zero e variância constante.

Pa se contornar o problema da heterocedasticidade, os modelos 1 e 2 foram ajustados pelo método dos quadrados mínimos ponderados, tendo como peso $1 /\left(\right.$ dap) ${ }^{3}$. Pela análise dos gráficos de resíduos e dos testes " $t$ " dos coeficientes de regressão, o melhore ajuste foi conseguido com o modelo 2, que foi aplicado na seguinte formula:

$$
\begin{aligned}
& V_{i}=0,005698-0,002700\left(d_{i}\right)+0,0005226\left(d_{i}\right) \\
& (0,0007777)(0,001159) \quad(0,00003261)
\end{aligned}
$$

onde, os valores entre parênteses são os erros padrão das estimativas dos coeficientes de regressão. Todos os testes " $t$ " para os coeficientes de regressão foram estatisticamente significativos ao nível de probabilidade de $5 \%$ e o coeficiente de determinação $\left(\mathrm{R}^{2}\right)$ foi de 0,9174 , indicando que aproximadamente $92 \%$ da variabilidade do volume pode ser explicada pelo modelo.

A estimativa do volume da floresta pelo método de quadrantes foi obtida pelo produto da densidade da floresta $\left(\mathrm{ha}^{-1}\right)$, pelo volume médio das árvores medidas no método de quadrantes $\left(\mathrm{m}^{3}\right)$ :

$$
\mathbf{V}=\mathbf{N}_{\mathbf{p}-\mathbf{v}}
$$


onde:

V é o volume da floresta $\left(\mathrm{m}^{3} \cdot \mathrm{ha}^{-1}\right)$;

Np é a densidade da floresta pelo estimados de Pollard $\left(\mathrm{ha}^{-1}\right)$; e

$\mathrm{V}$ é o volume médio das árvores medidas $\left(\mathrm{m}^{3}\right)$.

A variância da estimativa do volume da floresta foi obtida pela fórmula de propagação da incerteza apresentada por Vuolo (1998) para o caso específico de uma estimativa gerada pelo produto de duas estimativas:

$$
\operatorname{Var}(\mathbf{V})=\operatorname{Var}(\mathbf{v}) \mathbf{N}_{\mathbf{p}}{ }^{2}+\operatorname{Var}\left(\mathbf{N}_{\mathbf{p}}\right) \mathbf{v}^{2}
$$

onde a expressão $\operatorname{Var}(w)$ indica a variância da estimativa $w$. Para se obter intervalos de confiança aproximados, com coeficiente de confiança de 95\%, utilizou-se a expressão:

\author{
Limite Inferior: $V-1,96[\operatorname{Var}(V)]^{0,5}$ \\ Limite Superior: $\mathrm{V}+1,96[\operatorname{Var}(\mathrm{V})]^{0,5}$
}




\section{RESULTADOS E DISCUSSÃO}

\subsection{Tempo gasto para a amostragem}

Para a implantação dos dois métodos de amostragem comparados neste estudo, foram realizadas caminhadas pelas trilhas da grade de amostragem, numa área de abrangência de 64 hectares. Entretanto, a área efetivamente amostrada é diferente para os dois métodos. Para o método das parcelas, corresponde à soma da área das parcelas, ou seja, 5,76ha. Para o método de quadrantes, equivale à soma das áreas das árvores amostradas, ou 1,48ha.

A Tabela 1 apresenta alguns resultados obtidos pela aplicação dos dois métodos, e também relativos à montagem do delineamento amostral. Nota-se que o número de indivíduos amostrados pelo método de quadrantes representa $17,02 \%$ do número encontrado pelo método de parcelas. Enquanto no primeiro método são amostrados 4 indivíduos por unidade amostral (1 por quadrante), no segundo, foram amostrados em média, 118 indivíduos.

Nas 64 parcelas instaladas (5,76ha), foram amostrados 7520 indivíduos (367 mortos) distribuídos entre 140 espécies, 103 gêneros e 45 famílias. Das 140 espécies, dez $(7,14 \%)$ foram identificadas até gênero, duas $(1,43 \%)$ foram identificadas apenas em nivel de família e cinco $(3,57 \%)$ outros taxa não foram identificados nem em nível de família. Desta forma, $17(12,14 \%)$ taxa não foram identificados em nível de espécie. Os 59 indivíduos sem identificação no nível de família representaram $0,69 \%$ do total de indivíduos amostrados. A não identificação de espécies deveu-se a dificuldades de coleta de material botânico, uma vez que o período de seca na região foi bastante acentuado. 
Isto refletiu na caducifolia prolongada das árvores entre os anos de 2001 e 2002. Esse período de seca foi um dos mais intensos dos últimos anos ocasionando, inclusive, o racionamento de energia elétrica em vários estados do país. Outro fator que influenciou na identificação foi o fato de muitos materiais serem analisados apenas por material vegetativo, pois muitas espécies não apresentaram floração durante o período de coleta. A lista das espécies, classificadas em ordem alfabética por família, é apresentada no Anexo A.

Nos 320 pontos quadrantes amostrados foram amostrados 1280 indivíduos (8 mortos) pertencentes a 95 espécies, 76 gêneros e 37 famílias. Das 95 espécies, cinco $(5,26 \%)$ foram identificadas até gênero e duas $(2,10 \%)$ foram identificadas apenas em nível de família. Assim, 7 (7,37\%) taxa não foram identificados a nível de espécie.No Anexo B estão relacionadas estas espécies em ordem alfabética por família.

A listagem das espécies ocorrentes na área é um dos importantes componentes de um laudo pericial bem fundamentado, entretanto, essa lista deve ser a mais completa possivel. Segundo Schwenck Jr. (2000), um os grandes problemas observados em laudos de desapropriação de áreas na Serra do Mar, está na identificação botânica dos espécimens.

A proporção do número de gêneros, de espécies e de indivíduos arbóreos por famílias é uma informação que deverá compor o laudo, porém, se a identificação botânica não for completa, ou seja, ficar apenas no nível de gênero, poderá não alcançar o objetivo de subsidiar a classificação da madeira, segundo as classes comerciais, uma vez que espécies de mesmo gênero podem apresentar características tecnológicas diferentes, resultando em potencial de utilização e preços diferentes.

No presente estudo, as listagens de espécies obtidas pelos dois métodos apresentaram identificação parcial de poucas espécies, correspondendo a $12,14 \%$ das espécies nas parcelas e $7,37 \%$ nos quadrantes.

Considerando o esforço de campo para a implantação dos 320 pontos quadrantes, incluindo-se a mensuração dos indivíduos amostrados e a coleta do respectivo material botânico, com uma equipe de três pessoas, foram gastos, cerca de 20 dias de trabalho. $\mathrm{O}$ método de parcelas demandou um tempo cinco vezes maior. Para cada parcela foram 
gastos, em média, um dia e meio de trabalho. No inicio dos trabalhos este tempo foi maior, pois a equipe ainda não estava treinada e também não conhecia a maioria das espécies. Posteriormente, essas dificuldades foram sendo sanadas.

Tabela 1. Resultados obtidos relativos ao delineamento amostral pelos métodos de parcelas e quadrantes na floresta da Estação Ecológica dos Caetetus - Gália, SP

\begin{tabular}{l|c|c}
\hline \multicolumn{1}{c|}{ Critério } & Parcelas & Quadrantes \\
\hline Unidade amostral & $10 \times 90 \mathrm{~m}$ & Ponto (4 árvores) \\
Número de unidades amostrais & 64 & 320 \\
Área de abrangência (ha) & 64 & 64 \\
Área efetivamente amostrada (ha) & 5,76 & 1,48 \\
Número de indivíduos amostrados & 7520 & 1280 \\
Indivíduos mortos (\%) & 4,96 & 0,6 \\
Número de famílias & 45 & 37 \\
Número de gêneros & 106 & 77 \\
Número de espécies & 140 & 95 \\
\hline
\end{tabular}

Cabe ressaltar que a área de amostragem do atual estudo apresenta um relevo praticamente plano, o que acabou facilitando nas tarefas de campo. Provavelmente em outras áreas de relevo mais acidentado, como por exemplo, na Serra do Mar, a diferença de tempo de instalação dos dois métodos, certamente será maior.

Apesar de a amostragem por quadrantes demandar apenas 1/5 do tempo gasto para a instalação em relação ao método de parcelas, pode-se observar, através dos dados da tabela 1 , que aquele método amostrou $68 \%$ do número de espécies encontradas pelo método de parcelas.

Gorenstein (2002), ao comparar estes mesmos métodos em outra área de floresta da Estação Ecológica do Caetetus, observou que o método de quadrantes amostrou uma riqueza de espécies $17 \%$ maior em relação ao método de parcelas. Entretanto, naquele 
estudo, enquanto a área de abrangência das parcelas foi de 1 hectare, para os quadrantes, foi de 11,52ha. Estes dados concordam com o obtidos por Cavassan (1990), quando menciona a conveniência de que o método de quadrantes seja utilizado em áreas extensas, dando uma idéia mais geral da comunidade, resultando em um bom indicador do número de espécies em uma área.

No presente estudo, a riqueza de espécies foi melhor obtida pelo método de parcelas. Esse resultado deveu-se à área efetivamente amostrada nas parcelas, que foi praticamente 4 vezes maior do que aquela dos quadrantes.

Na Figura 5 são apresentadas as curvas do coletor para os dois métodos. Essa curva representa o incremento de novas espécies à medida, em que foram acrescentadas novas unidades amostrais. Considerou-se, para cada unidade amostral da figura, cinco pontos quadrantes, o que corresponde à quantidade de pontos "dentro" de cada parcela primaria. Assim, para a curva dos quadrantes, a unidade amostral 1 corresponde ao acúmulo de espécies até o ponto 5 , na unidade 2 corresponde ao acúmulo até o ponto 10 e assim por diante, até os últimos 5 pontos que correspondem à parcela 64. Percebe-se que, de maneira geral, as duas curvas mostram-se semelhante, com inclinação mais acentuada até à unidade amostral 13, diminuindo posteriormente e tendendo à maior estabilidade, a partir da unidade 41. A curva das parcelas apresentou-se superior, devido ao maior número médio de espécies por unidade amostral. Não são observados sobressaltos na curvas. Isto pode ser interpretado como uma característica de homogeneidade da vegetação estudada. A semelhança entre as curvas ocorreu porque a área de abrangência dos dois métodos aplicados é a mesma.

Para o método de parcelas, as familias com maior número de gêneros foram: Mimosaceae com 10 (9,43\% do total), seguida por Myrtaceae com $9(8,49 \%)$, Euphorbiaceae com $7(6,60 \%)$, Rutaceae $5(4,72 \%)$ e Meliaceae e Sapindaceae com 4 $(3,77 \%)$ gêneros cada uma. A Figura 6 mostra a contribuição percentual, em número de gêneros, dessas famílias e das restantes identificadas, pelo método de parcelas.

Quanto ao método dos quadrantes, se destacaram as famílias Mimosaceae com 7 gêneros $(9,09 \%$ do total), Euphorbiaceae e Myrtaceae com 6 (7,79\%), Rutaceae e Sapindaceae com $4(5,19 \%)$ e Caesalpinaceae, Fabaceae, Lauraceae, Rubiaceae e 
Meliaceae com $3(3,90 \%)$ gêneros respectivamente. A Figura 7 mostra a contribuição das famílias, em percentagem do número de gêneros pelo método dos quadrantes.

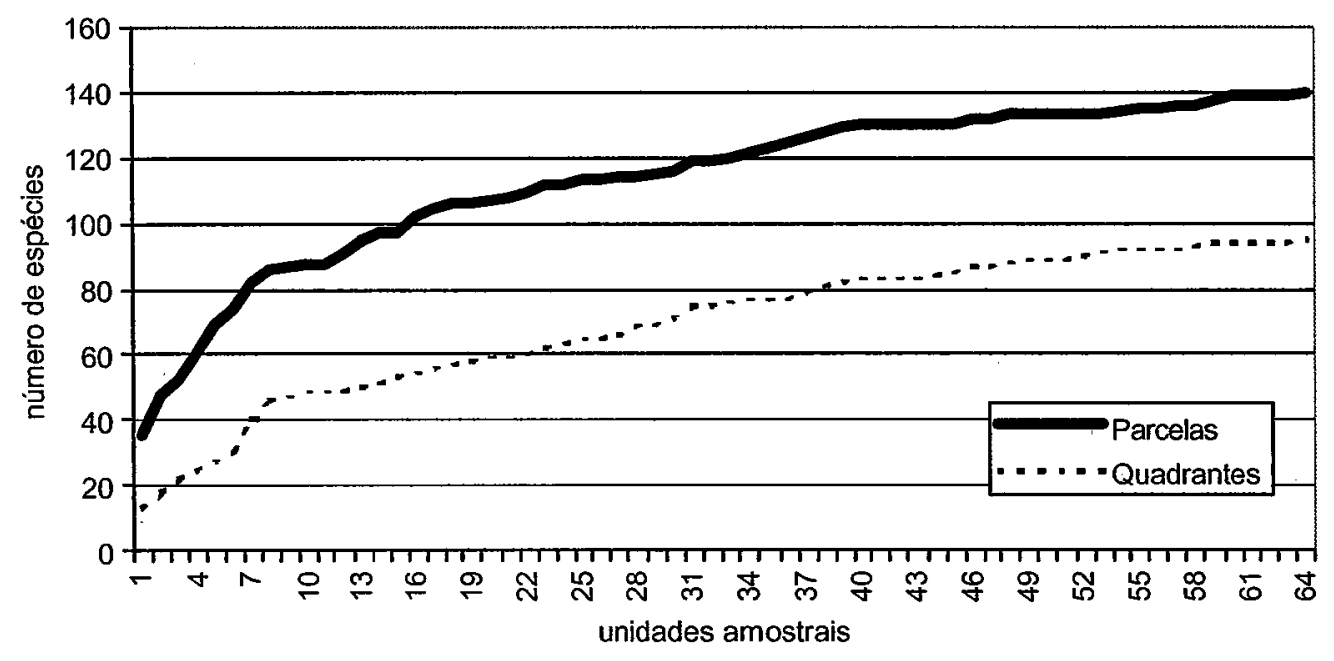

Figura 5 - Representação gráfica da curva do coletor para amostragem através dos métodos de parcelas e quadrantes, em floresta da Estação Ecológica dos Caetetus - Gália, SP

\subsection{Florística}

Nota-se que as quatro principais famílias em número de gênero foram iguais nos dois métodos, apenas com a troca de posição entre Euphorbiaceae e Myrtaceae.

Os gêneros mais representados nas parcelas foram: Trichilia (Meliaceae) e Campomanesia (Myrtaceae), cada um com 5 espécies, seguidos por Ocotea (Lauraceae), com 4 espécies e Cordia (Boraginaceae), Casearia (Flacourtiaceae) e Zanthoxylum (Rutaceae), com 3 espécies cada um. Nos quadrantes, Trichilia (Meliaceae) apresentou 4 espécies, seguido por Campomanesia (Myrtaceae) e Casearia (Flacourtiaceae), com 3 espécies respectivamente. 


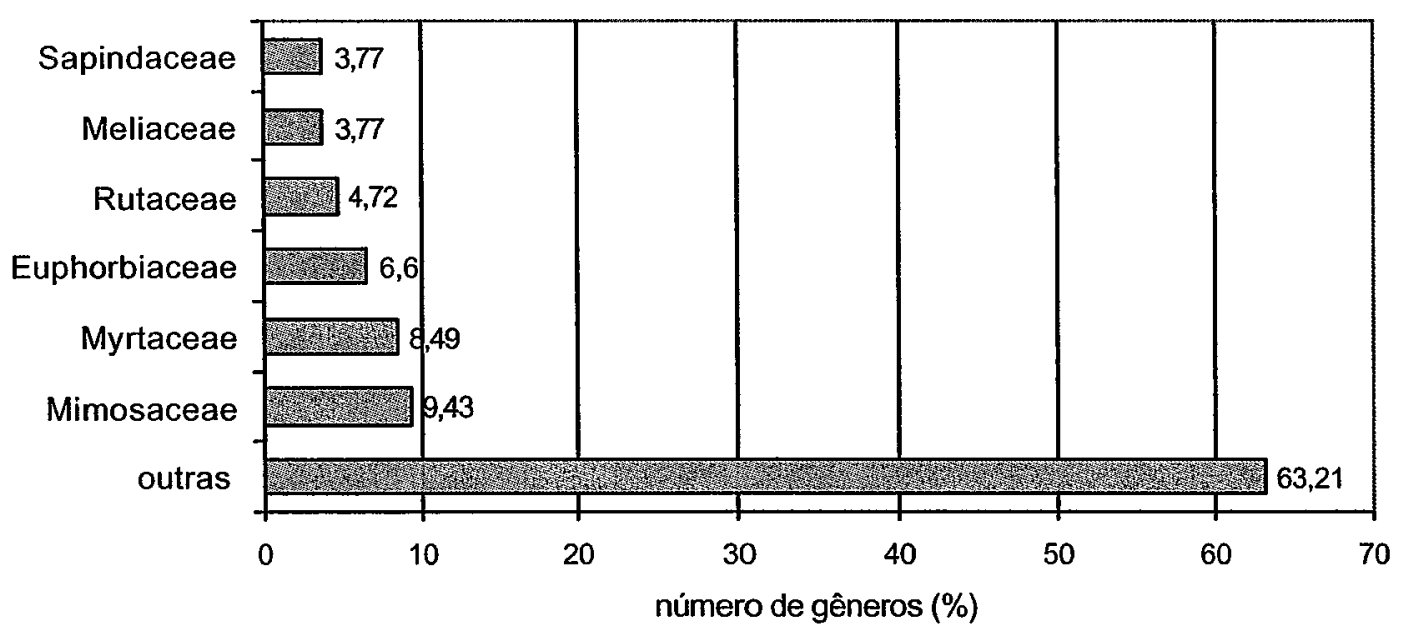

Figura 6 - Contribuição das principais famílias em percentagem do número de gêneros, na composição florística da floresta da Estação Ecológica dos Caetetus Gália, SP. Amostragem pelo método de parcelas

Além da coincidência da maioria dos gêneros nos dois métodos, percebe-se que há predominância de gêneros que são caracterizados por espécies que preferem os estratos mais inferiores da floresta, tais como Trichilia, Casearia e Zanthoxylum.

Quanto ao número de espécies, na amostragem por parcelas, a família mais representada foi Myrtaceae com 15 (10,71\%), vindo a seguir, Mimosaceae com 12 (8,57\%), Meliaceae com 9 (6,42\%), Euphorbiaceae com 8 (5,71\%), Rutaceae com 7 (5\%), Lauraceae com $6(4,28 \%)$ e Flacourtiaceae e Sapindaceae com 5 (3,57\%) espécies cada. Essa distribuição é apresentada na Figura 8.

Nos quadrantes, Mimosaceae e Myrtaceae se destacaram com 9 (9,47\% do total) cada uma e seguiram-se Euphorbiaceae com 7 (7,37\%) espécies, Meliaceae com 6 (6,32\%) espécies, Rutaceae com 5 (5,26\%) espécies e Flacourtiaceae, Lauraceae, Fabaceae e Sapindaceae, com 4 (4,21\%) espécies cada uma. A Figura 9 apresenta essa distribuição. 


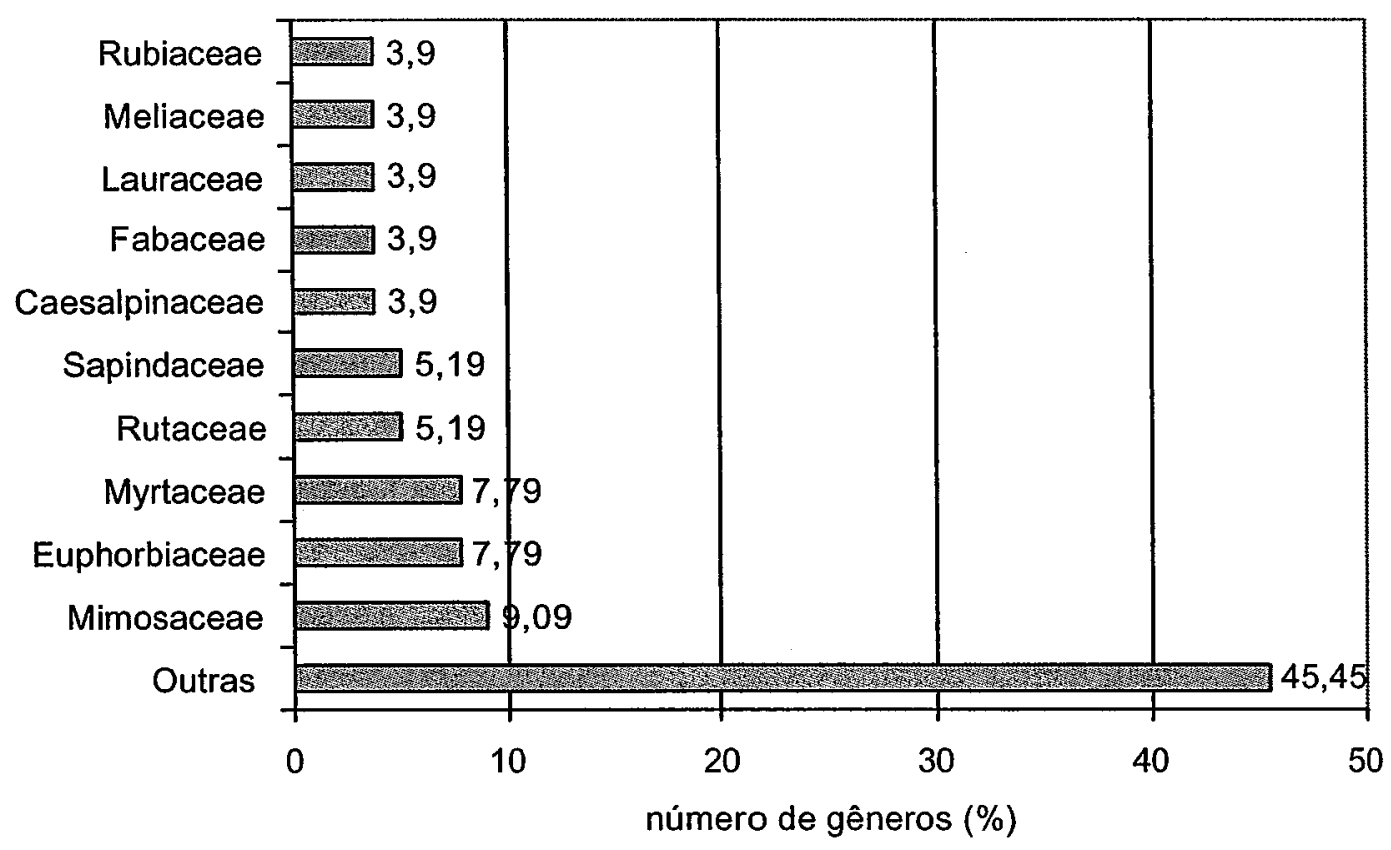

Figura 7 - Contribuição das principais famílias em percentagem do número de gêneros, na composição florística da floresta da Estação Ecológica dos Caetetus Gália, SP. Amostragem pelo método de quadrantes

Enquanto nas parcelas, 8 famílias contribuíram com $47,83 \%$ das espécies, 17 famílias equivalentes a $12,14 \%$ do total, foram amostradas por uma espécie cada. Nos quadrantes 9 famílias contribuíram com $54,73 \%$ do total de espécies existentes e 15 correspondentes a 40,54\% do total, foram amostradas por uma espécie.

Ao serem comparadas as famílias mais representativas, tanto em número de gêneros como de espécies, obtidas pelos dois métodos, observa-se que, nestes aspectos, os métodos amostraram convenientemente a área, obtendo resultados similares aos encontrados em outros estudos realizados em áreas de floresta estacional semidecidual, onde as dez famílias mais representativas, normalmente, aparecem em destaque também nas outras áreas, porém, nem sempre na mesma ordem (Baitello, 1988; Schlittler, 1990; Franco 2002; Durigan 2000; Ivanauskas \& Rodrigues 2000; Silva e Soares 2002 e Werneck et al., 2000). A família Myrtaceae, segundo Peixoto e Gentry (1990), também 
assume grande importância nas florestas da encosta atlântica do Brasil, onde é encontrada com grande riqueza de espécies e abundância.

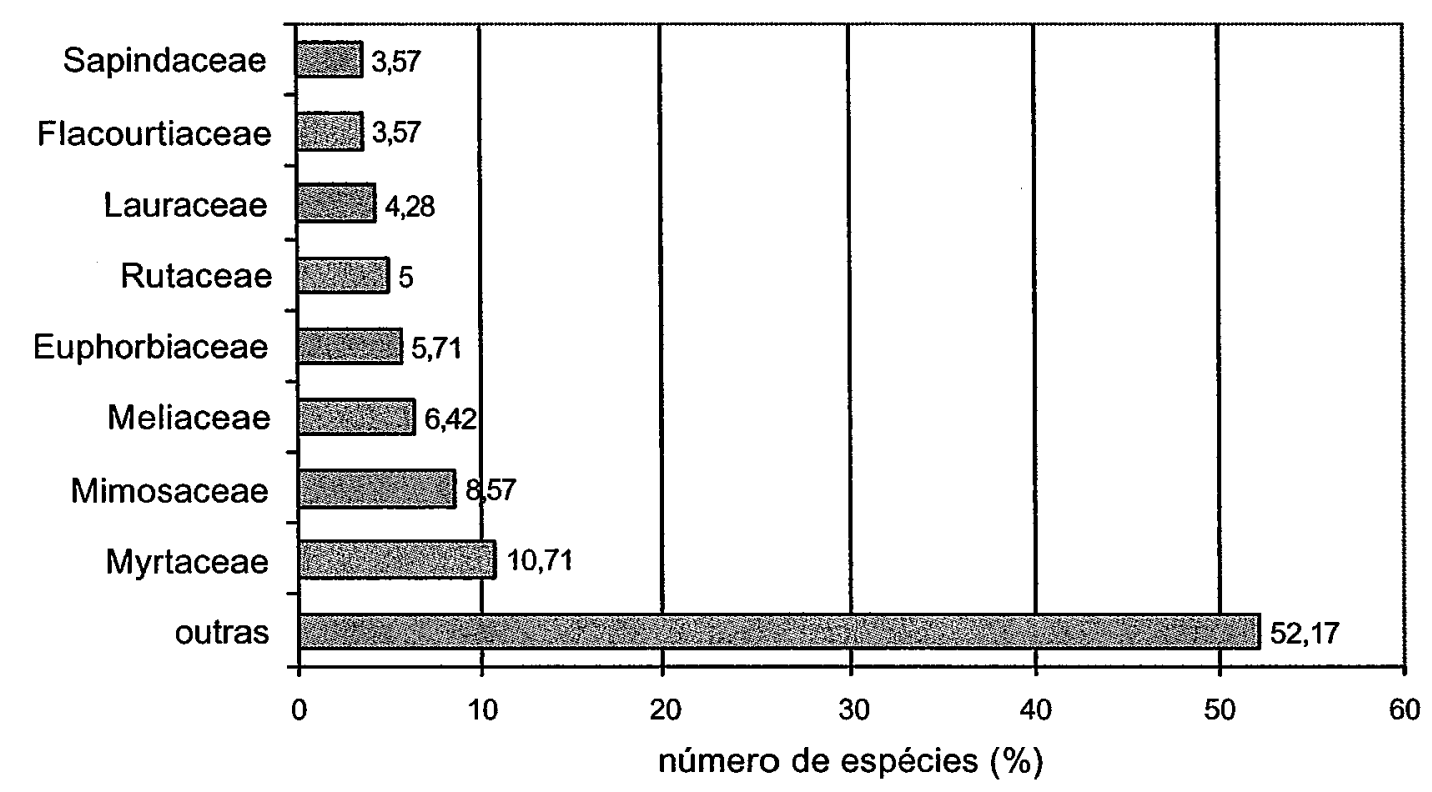

Figura 8 - Contribuição das principais famílias em percentagem de número de espécies, na composição florística da floresta da Estação Ecológica dos CaetetusGália. Amostragem pelo método de parcelas

Observando-se a Figura 10, pode-se constatar que $84,71 \%$ dos indivíduos amostrados pelo método de parcelas são representados por apenas 10 famílias. Rutaceae apresentou o maior número de indivíduos (3.667), o que correspondeu a 48,76\% do total. Meliaceae veio em seguida, com 528 indivíduos (7,02\%) e, posteriormente a família Apocynaceae, com 427 indivíduos (5,68\%), Fabaceae, com 357 indivíduos (4,75, Lauraceae, com 329 indivíduos (4,37\%), Euphorbiaceae, com 303 indivíduos (4,03\%), Myrtaceae, com 241 indivíduos (3,21\%), Arecaceae, com 229 indivíduos (3,04\%), Mimosaceae, com 174 indivíduos (2,31\%) e Sapindaceae, com 115 indivíduos (1,54\%). Os $15,29 \%$ ou 1150 indivíduos restantes pertenceram a outras 35 famílias 


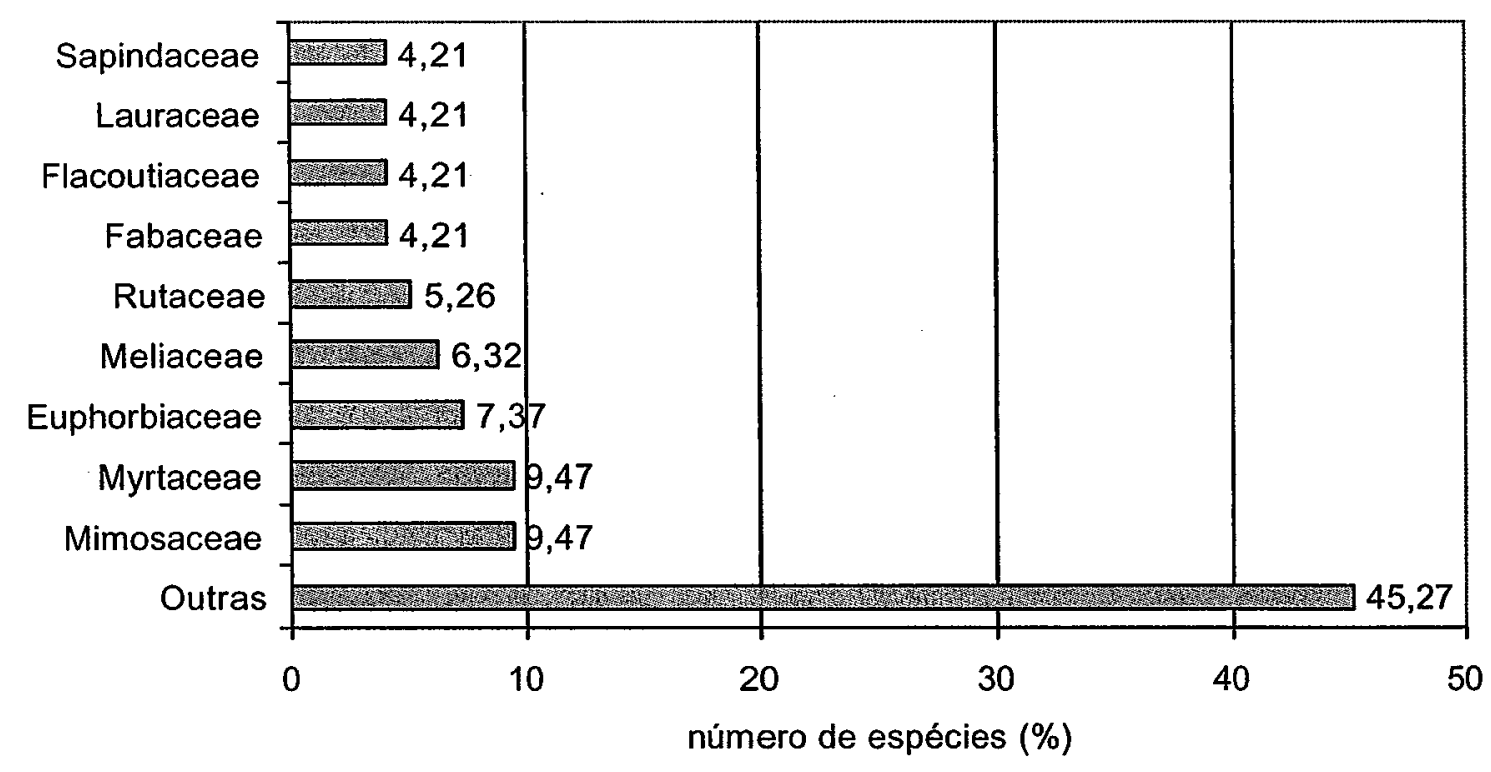

Figura 9 - Contribuição das principais famílias em percentagem de número de espécies, na composição florística da floresta da Estação Ecológica dos Caetetus Gália, SP. Amostragem pelo método de quadrantes

A espécie com maior número de indivíduos no método de parcelas foi Metrodorea nigra, com 3421 (45,49\%) plantas, seguida por Aspidosperma polyneuron com 408 (5,43\%), Trichilia catigua, com 309 (4,11\%), Ocotea indecora, com 266 (3,54\%), Balfourodendron riedelianum com 190 (2,53\%), Centrolobium tomentosum, com 221 (2,94\%) e Syagrus romanzoffiana com 167 (2,22\%) indivíduos amostrados. As 10 espécies mais representadas perfazem $71,28 \%$ dos indivíduos estudados.

Nos quadrantes, 5 famílias foram responsáveis por $72,35 \%$ dos indivíduos amostrados, sendo que Rubiaceae apresentou o maior número (652), correspondendo a $50,94 \%$ dos indivíduos amostrados. Bastante distante desse valor, a família Meliaceae veio em seguida com 85 ou $6,64 \%$ dos indivíduos amostrados, vindo posteriormente Lauraceae com 73 indivíduos ou 5,70\%, Apocynaceae com 67 indivíduos ou 5,23\%, e Fabaceae com 56 plantas ou 4,38\% dos indivíduos amostrados. Os $27,65 \%$ restantes são representados por indivíduos pertencentes a outras 32 famílias. Esses números são 
apresentados na Figura 11. Ainda com relação ao método de quadrantes, 15 famílias (40,54\% do total), foram amostradas por uma única espécie.

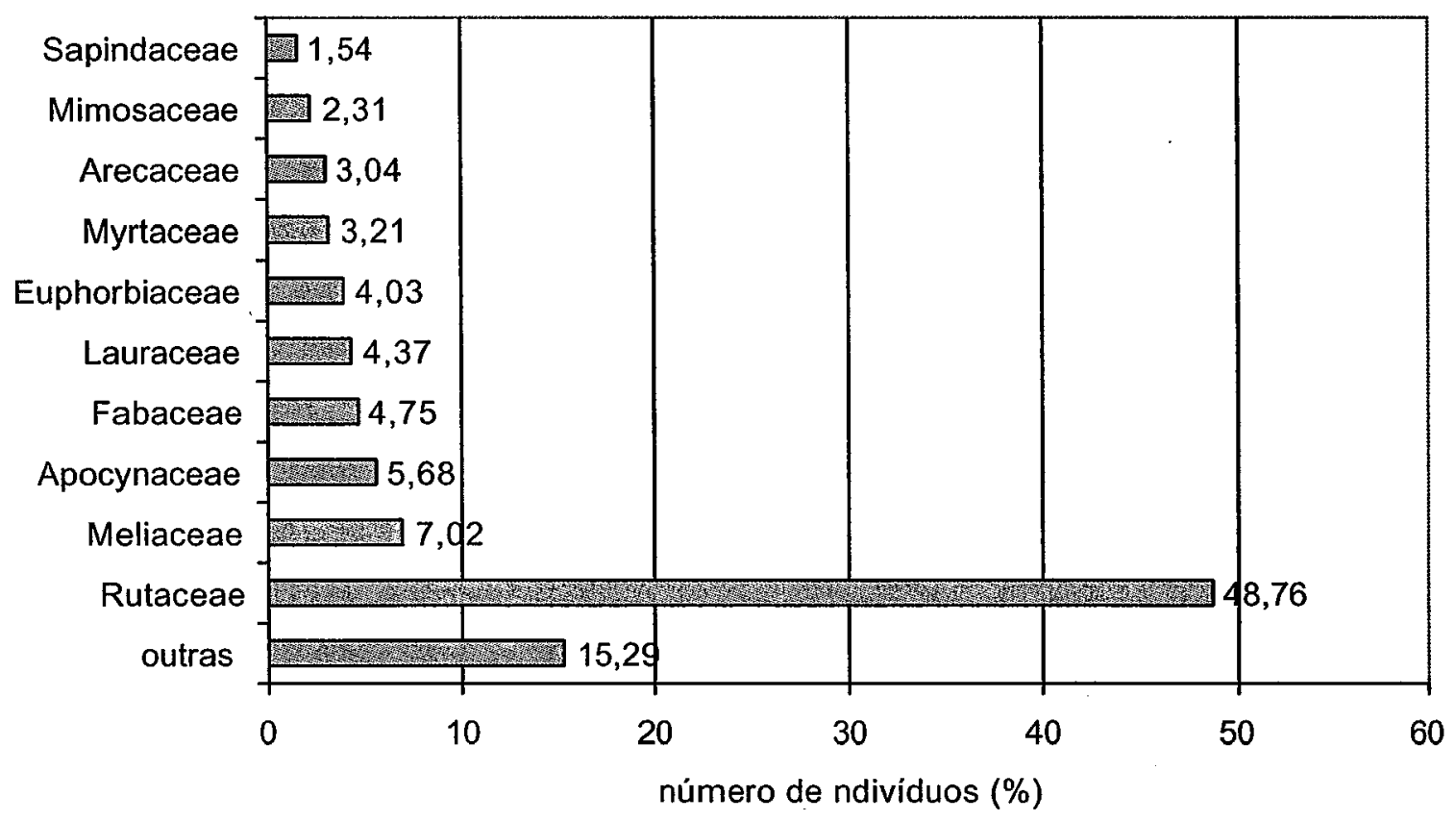

Figura 10 - Contribuição das principais famílias em percentagem de número de indivíduos, na composição florística da floresta da Estação Ecológica de Caetetus - Gália, SP. Amostragem pelo método de parcelas

As espécies praticamente se repetiram. Foram amostrados 610 (47,65\%) indivíduos de Metrodorea nigra (Rutaceae), seguida de Aspidosperma polyneuron com 66 (5,16\%), Ocotea indecora com 65 (5,08\%), Trichilia catigua com 55 (4,30\%), Syagrus romanzoffiana com 38 (2,97\%), Balfourodendron riedelianum com 35 (2,73\%) e Centrolobium tomentosum com 33 ou 2,58\% dos indivíduos. Juntas, as árvores dessas 6 espécies representaram $68,16 \%$ de todos os indivíduos vivos amostrados. Do total de espécies amostradas, 37 ou 38,95\% foram representadas por apenas um indivíduo.

A Tabela 2. apresenta a comparação do percentual de indivíduos das principais espécies amostradas nos dois métodos. Observa-se que das oito espécies mais 
representadas, apenas A. polyneuron e Centrolobium tomentosum foram mais amostradas pelo método de parcelas. As diferenças são pequenas entre os dois métodos, entretanto, corroboram com a conclusão de Gorenstein (2002), onde o método de quadrantes superestima a densidade arbórea para espécies com padrão regular e subestima a densidade para aquelas de padrão espacial agrupado

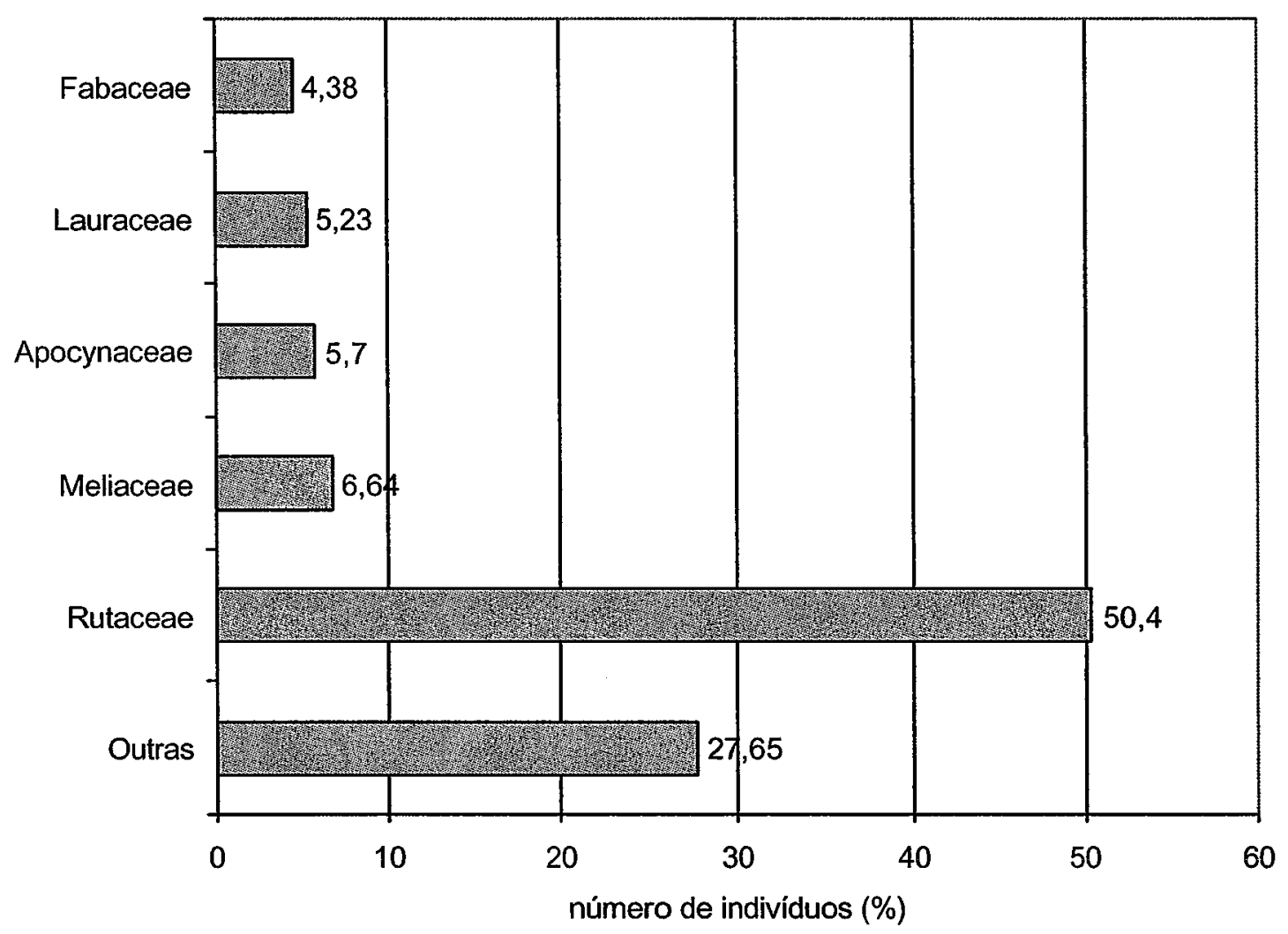

Figura 11 - Contribuição das principais famílias em percentagem de número de indivíduos, na composição florística da floresta da Estação Ecológica de Caetetus - Gália, SP. Amostragem pelo método de quadrantes

Tabela 2. Espécies mais representadas em dois métodos de amostragem na floresta da Estação Ecológica dos Caetetus - Gália, SP 


\begin{tabular}{l|c|c}
\cline { 2 - 3 } \multicolumn{1}{c|}{} & \multicolumn{2}{c}{ Número de indivíduos amostrados (\%) } \\
\hline Eetrócie & Método de parcelas & Método de quadrantes \\
Aspidosperma polyneuron & 45,49 & 47,65 \\
Trichilia catigua & 5,43 & 5,16 \\
Ocotea indecora & 4,11 & 4,30 \\
Centrolobium tomentosum & 3,54 & 5,08 \\
Balfourodendron riedelianum & 2,94 & 2,58 \\
Syagrus romanzoffiana & 2.53 & 2,73 \\
\hline
\end{tabular}

\subsection{Grupos ecológicos e estrutura vertical}

A Tabela 3 apresenta a quantidade de indivíduos amostrados nos dois métodos aplicados, considerando-se os grupos ecológicos. Nessa tabela, pode-se observar, que em termos percentuais, os dois métodos de amostragem apresentaram resultados com pequenas diferenças.

Enquanto nas parcelas as espécies pioneiras (P) significaram $12,14 \%$ das espécies e 3,47\% dos indivíduos, nos quadrantes estas representaram $11,58 \%$ das espécies e $3,46 \%$ do total de indivíduos vivos amostrados. Dados semelhantes também foram observados por Tabanez (1997) e Viana e Tabanez (1996), em fragmentos de floresta estacional semidecidual na região de Piracicaba. Segundo Martinez-Ramos (1985),em florestas maduras estas espécies têm maior probabilidade de serem encontradas apenas em grandes clareiras, formadas a partir de distúrbios naturais, as quais ocupam apenas cerca de $1 \%-2 \%$ das áreas das florestas. Apesar disso, poucas espécies que inicialmente são beneficiadas por estas perturbações continuam a exercer um alto grau de dominância local (Nascimento et al. 2000).

Tabela 3. Número e percentual de espécies e indivíduos amostrados na floresta da Estação Ecológica do Caetetus, Gália - SP., considerando-se os Grupos 
Ecológicos (GE). $\mathrm{P}=$ espécies pioneiras; $\mathrm{H}=$ não pioneiras heliófitas; $\mathrm{U}=$ não pioneiras umbrófilas; $\mathrm{UH}=$ não pioneiras umbrófilas quando jovem

\begin{tabular}{c|cccc|cccc}
\cline { 2 - 9 } & \multicolumn{3}{|c|}{ Método de Quadrantes } & \multicolumn{4}{c}{ Método de Parcelas } \\
\hline GE & Esp. & $\begin{array}{c}\text { Esp. } \\
(\%)\end{array}$ & Indiv. & $\begin{array}{c}\text { Indiv. } \\
(\%)\end{array}$ & Esp. & $\begin{array}{c}\text { Esp. } \\
(\%)\end{array}$ & Indiv. & $\begin{array}{c}\text { Indiv. } \\
(\%)\end{array}$ \\
$\mathrm{P}$ & 11 & 11,58 & 44 & 3,46 & 17 & 12,14 & 248 & 3,47 \\
$\mathrm{H}$ & 34 & 35,79 & 231 & 18,16 & 45 & 32,14 & 1249 & 17,48 \\
$\mathrm{U}$ & 24 & 25,26 & 841 & 66,12 & 33 & 23,57 & 4616 & 64,57 \\
$\mathrm{UH}$ & 21 & 22,20 & 146 & 11,47 & 28 & 20,00 & 941 & 13,16 \\
$\mathrm{~S}$ & 5 & 5,26 & 10 & 0,78 & 17 & 12,14 & 93 & 1,31 \\
\hline
\end{tabular}

Com relação as heliófitas $(H)$, exigentes de luz em todas as fases do desenvolvimento, estas significaram $32,14 \%$ das espécies e $17,48 \%$ dos indivíduos amostrados nas parcelas e $35,79 \%$ das espécies e $18,16 \%$ dos indivíduos amostrados nos quadrantes. A presença do número pequeno de indivíduos dessas espécies aponta na direção de uma floresta madura. De acordo com Rodrigues (1992), as espécies secundárias iniciais aparecem freqüentemente em destaque na floresta estacional semidecidual, sendo tal fato geralmente atribuído ao histórico de perturbação desta formação.

As espécies umbrófilas (U) significaram $23,57 \%$ das espécies e $64,57 \%$ dos indivíduos nas parcelas e $25,26 \%$ das espécies e $66,12 \%$ dos indivíduos amostrados pelo método de quadrantes. Há que se considerar que entre essas espécies está a Metrodorea nigra, que representou $45,49 \%$ daqueles amostrados por parcelas e $47,65 \%$ do total de indivíduos amostrados por quadrantes. Quanto as umbrófilas quando jovens (UH), estas representaram $20 \%$ das espécies e $13,16 \%$ dos indivíduos selecionados nas parcelas e $22,10 \%$ das espécies e $11,47 \%$ dos indivíduos amostrados nos quadrantes.

Percebe-se, através dos dados a cima, que em termos percentuais, não houve diferenças marcantes entre os resultados dos dois métodos aplicados. 
A proporção entre o número de espécies mais dependentes de luz e aquelas mais umbrófilas apresentou-se equilibrada, sendo as heliófitas $(P+H)$ 47,37\% nos quadrantes e $44,28 \%$ nas parcelas, enquanto as umbrófilas $(\mathrm{UH}+\mathrm{U}$ ) representaram $47,63 \%$ nos quadrantes, contra $43,57 \%$ nas parcelas. Entretanto, esse equilíbrio não se manteve em relação ao número de indivíduos pertencentes a essas espécies. Se por um lado, os indivíduos das espécies heliófitas representaram 20,77\% das árvores amostradas nos quadrantes e 20,95\% nas parcelas, por outro lado, as espécies mais tardias (mais dependentes de sombra) representam a maioria, com $77,82 \%$ e $77,73 \%$ do total de indivíduos amostrados nos quadrantes e nas parcelas respectivamente.

O caráter tolerância à sombra é um parâmetro fundamental na classificação das espécies arbóreas tropicais, quanto ao estádio sucessional. A proporção entre indivíduos de espécies umbrófilas e heliófitas reflete, sobretudo o estádio sucessional em que se encontram as florestas (Durigan \& Leitão-Filho, 1995; Mantovani, 2002 ${ }^{2}$ ). Assim, tomando-se como base os resultados obtidos pela amostragem dos dois métodos, onde a maiorias dos indivíduos existentes na floresta pertencem a espécies mais dependentes de sombra em pelo menos uma fase do seu desenvolvimento, pode-se inferir que a área objeto deste estudo é coberta por floresta madura.

A proporção de indivíduos amostrados pelos dois métodos na composição da estrutura vertical da floresta é apresentada na Figura 12. Como já era esperado, nos dois métodos observou-se que a maioria das árvores está localizada nos estratos inferior e médio. $\mathrm{O}$ estrato inferior, foi melhor amostrado, percentualmente, pelo método das parcelas, onde foi representado por $72,24 \%$ dos indivíduos estudados, contra $69,26 \%$ nos quadrantes. Os outros estratos foram mais amostrados no método de quadrantes.

Os dados referentes à distribuição dos indivíduos pertencentes aos grupos ecológicos, conforme a posição vertical, são apresentados nas Figuras 13 e 14. Para os dois métodos, os indivíduos das espécies umbrófilas (U) foram observados em maior quantidade nos estratos inferiores. Nas parcelas, essas espécies predominaram com $78,23 \%$ do sub-bosque e $32,82 \%$ dos indivíduos observados no estrato médio. Pelo

\footnotetext{
${ }^{2}$ MANTOVANI, W. (2002) Anotações de aula do curso "Fitossociologia"
} 
método dos quadrantes, o predomínio das espécies umbrófilas foi ainda maior, com $81,72 \%$ dos indivíduos do sub-bosque e $39,79 \%$ do estrato médio.

Entre as árvores mais altas, notou-se a presença de mais indivíduos das espécies não pioneiras heliófitas $(\mathrm{H})$, onde, nas parcelas, seus indivíduos representaram 68,75\% do dossel e 63,83\% das emergentes. Nos quadrantes, os indivíduos dessas espécies representaram 67,74\% do dossel e 64,28\% das emergentes. Ao contrário da hipótese da contribuição dos períodos de deciduidade na época seca, que resultaria em maior luminosidade do sub-bosque, e conseqüentemente favoreceria a presença de indivíduos dessas espécies (Gandolfi et al., 1995; Morellato e Leitão-Filho, 1995), no presente estudo, a participação das heliófitas no sub-bosque é pequena, 7,84\% nas parcelas e $6,70 \%$ nos quadrantes.

As não pioneiras umbrófilas (UH), participam com 16,93\% no dossel e 21,28\% das emergentes, nas parcelas e, com 21,05\% dos indivíduos do dossel e 14,28\% das emergentes.

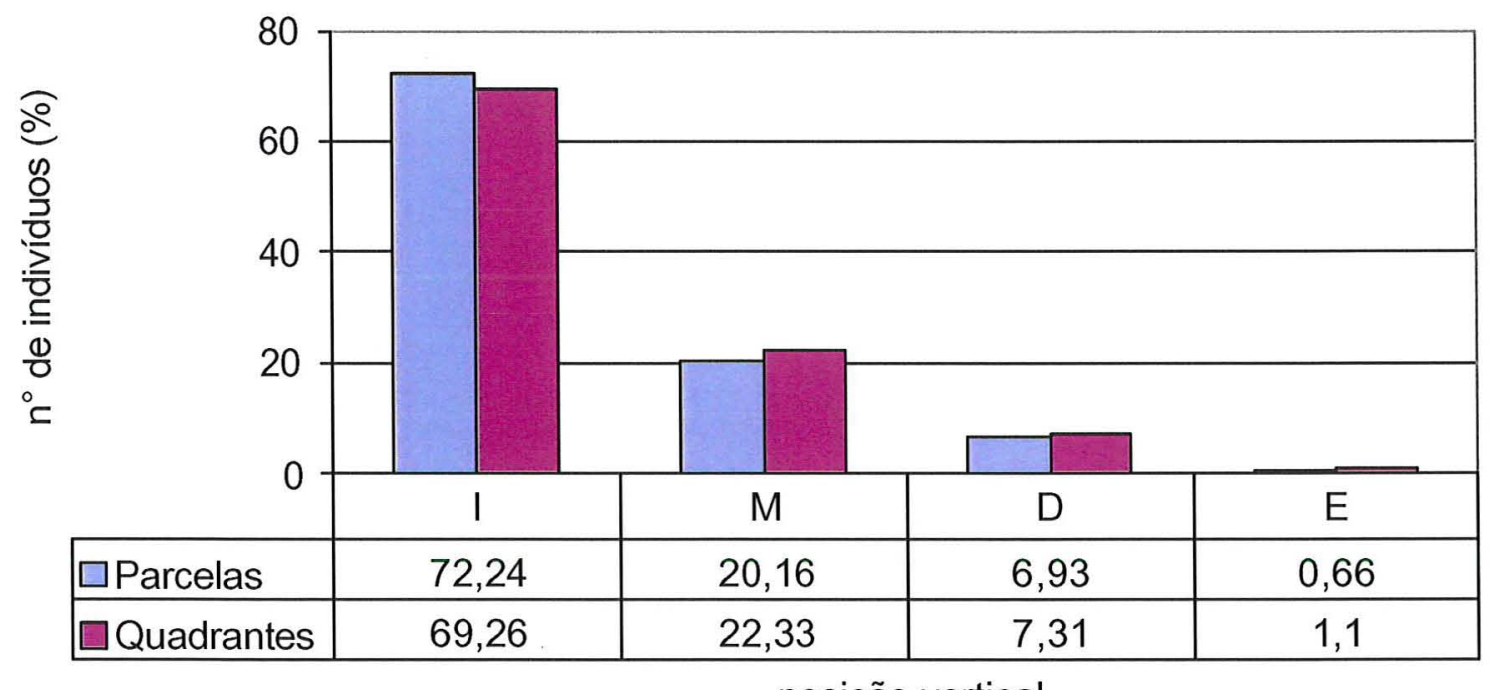

posição vertical

Figura 12 - Proporção dos indivíduos amostrados (\%) nos estratos, pelos métodos de parcela e quadrantes na floresta da Estação Ecológica dos Caetetus Gália, SP. I = Estrato inferior (sub-bosque); $\mathrm{M}=$ estrato médio; $\mathrm{D}=$ Dossel; $\mathrm{E}=$ Árvores emergentes 


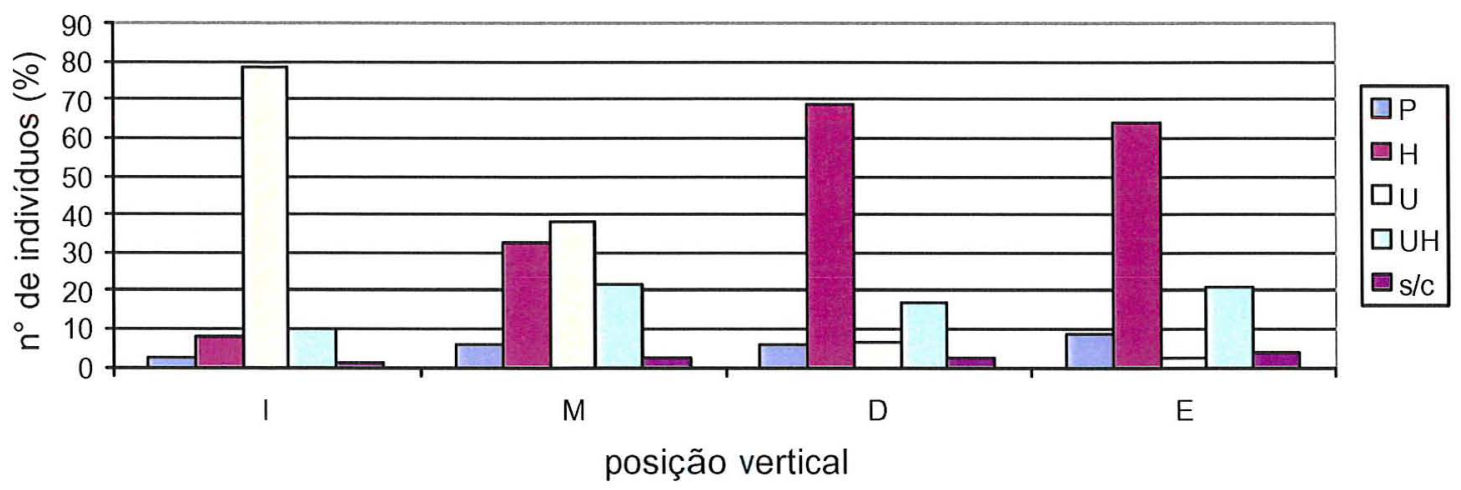

Figura 13 - Percentual de indivíduos vivos amostrados pelo método de parcelas na floresta da Estação Ecológica do Caetetus, Gália - SP., considerando-se os grupos ecológicos (onde $\mathrm{P}$ = espécies pioneiras; $\mathrm{H}$ = não pioneiras heliófitas; $\mathrm{U}=$ não pioneiras umbrófilas; $\mathrm{UH}=$ não pioneiras umbrófilas quando jovem), e a estrutura vertical, onde ; $\mathrm{I}$ = Inferior (subosque); $\mathrm{M}=$ Médio, $\mathrm{D}$ = Dossel; $\mathrm{E}=$ Emergentes

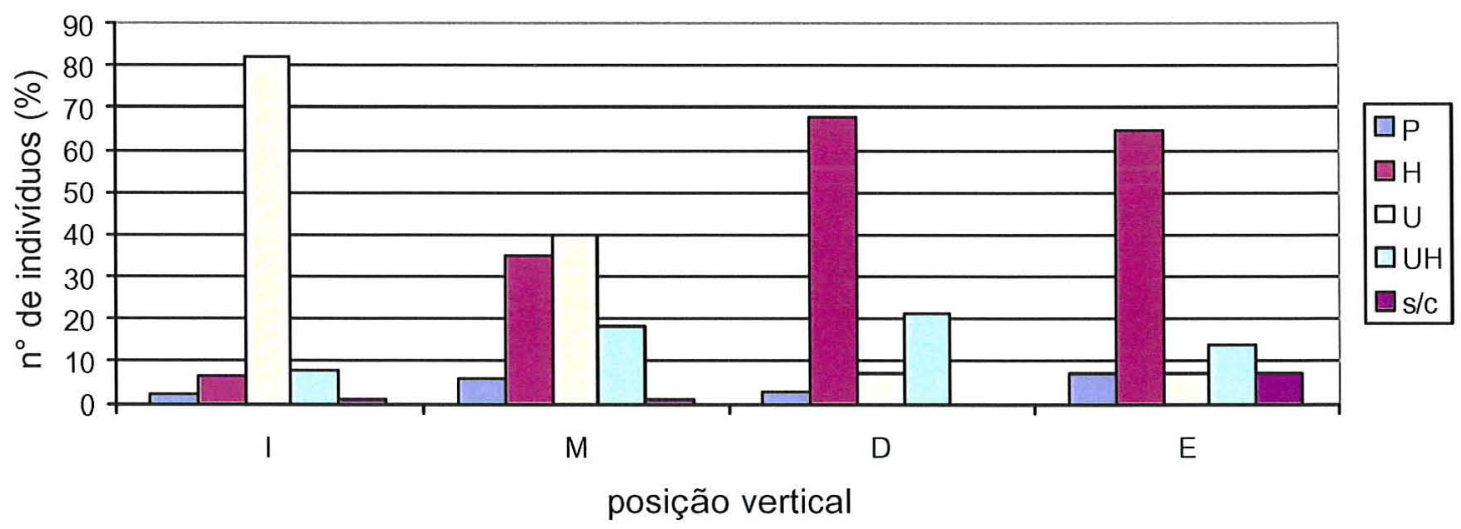

Figura 14 - Percentual de indivíduos vivos amostrados pelo método de quadrantes na floresta da Estação Ecológica do Caetetus, Gália - SP., considerando-se os grupos ecológicos (onde $\mathrm{P}=$ espécies pioneiras; $\mathrm{H}=$ não pioneiras heliófitas; $\mathrm{U}=$ não pioneiras umbrófilas; $\mathrm{UH}=$ não pioneiras umbrófilas 
quando jovem), e a estrutura vertical, onde ; I = Inferior (sub-bosque); $\mathrm{M}=$ Médio, $\mathrm{D}=$ Dossel; $\mathrm{E}=$ Emergentes

\subsection{Fitossociologia}

No Anexo 4 estão listadas as 140 espécies amostradas no levantamento pelo método de parcelas, com os seus respectivos parâmetros fitossociológicos e valores de volumes absoluto e relativo. Os dados estão classificados por ordem decrescente de Índice de Valor de Importância (ivi).

As dez espécies de maior IVI são: Metrodorea nigra (67,54), Aspidosperma polyneuron $(20,25)$, Ocotea indecora $(15,62)$, Centrolobium tomentosum $(12,07)$, Gallesia integrifolia (11,61), Balfourodendron riedelianum (10,74), Syagrus romanzoffiana $(10,43)$, Trichilia catigua $(9,00)$, Chrysophyllum gonocarpum $(6,44) \mathrm{e}$ Croton floribundus $(6,14)$. Essas espécies somaram 56,61\% do IVI total. Das 130 espécies restantes, 89 possuem IVIs menores do que 1, representando $63,57 \%$ das espécies amostradas e 9,24\% do IVI total. A Figura 15 apresenta a distribuição das 10 principais espécies em IVI e respectivas densidades, dominâncias e freqüências relativas obtidos nas parcelas.

A espécie Metrodorea nigra foi amostrada em todas as unidades amostrais e, portanto, apresentou frequiência absoluta de $100 \%$. Em seguida vieram A. polyneuron e T,catigua com $98,44 \%$ cada, $O$. indecora e $C$. tomentosum com $96,87 \%$ cada uma, $S$. romanzoffiana $(87,50 \%)$, B. riedelianum $(85,93 \%)$ e C. gonocarpum com $78,12 \%$.

$\mathrm{Na}$ área efetivamente amostrada de 5,76ha, foram amostradas 7520 árvores. A densidade absoluta total foi de 1.305,56 $\pm 38,30$ indivíduos por hectare (Intervalo de Confiança de 95\%). A área basal total foi de $31,82 \pm 2,2 \mathrm{~m}^{2} \mathrm{ha}^{-1}$. As espécies que apresentaram as maiores densidades absolutas foram M. nigra (594 ind.ha $\left.{ }^{-1}\right), A$. polyneuron (71 ind.ha $\left.{ }^{-1}\right), T$. catigua (54 ind ha $\left.{ }^{-1}\right)$, O. indecora $\left(47\right.$ ind ha $\left.{ }^{-1}\right), C$. tomentosum $\left(39\right.$ ind ha $\left.^{-1}\right), B$. riedelianum $\left(37 \mathrm{ind} \mathrm{ha}^{-1}\right), S$. romanzoffiana $\left(33 \mathrm{ind} \mathrm{ha}^{-1}\right) \mathrm{e}$ C. floribundus com 22 indivíduos por hectare. 


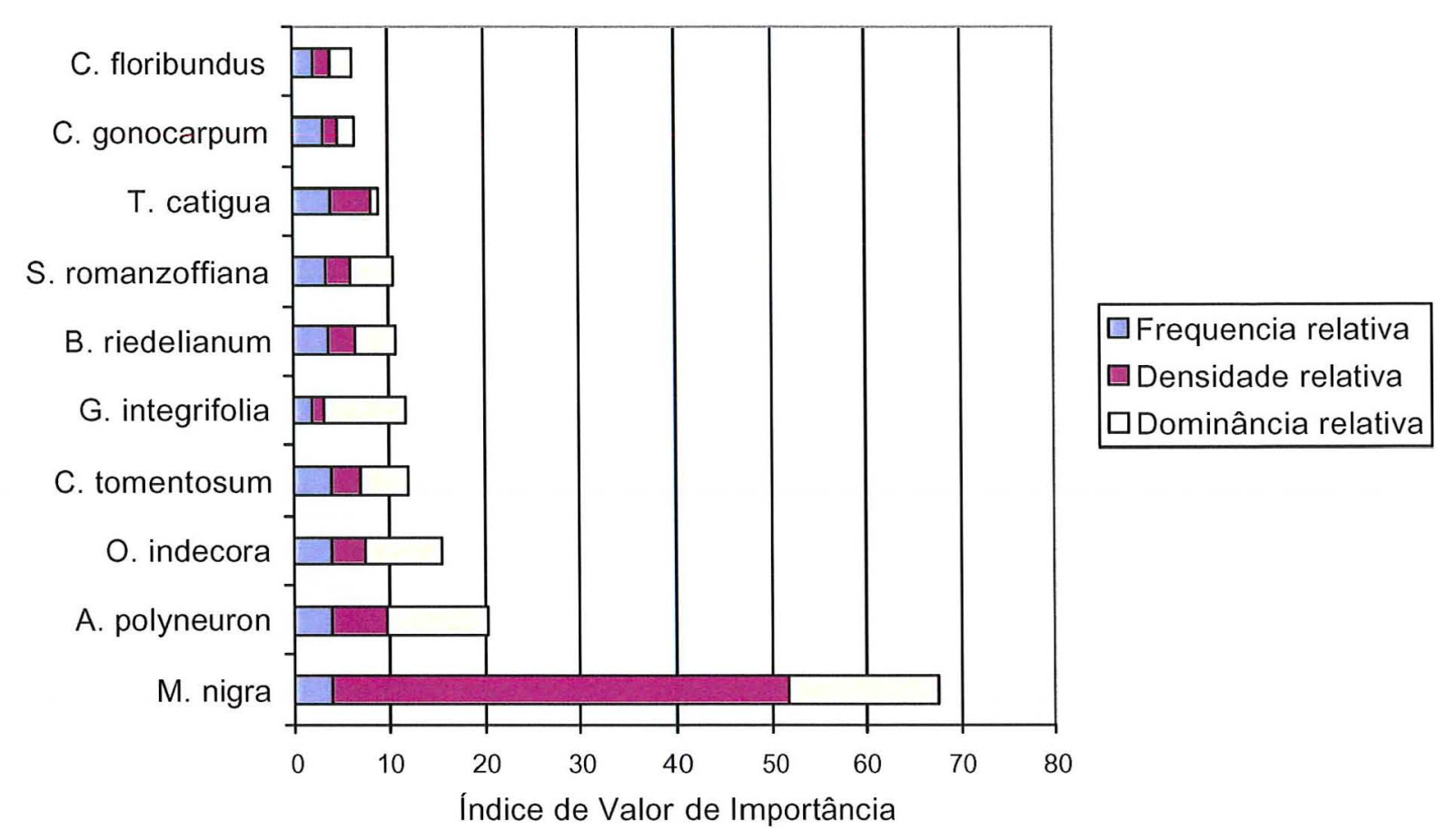

Figura 15 - Distribuição das 10 principais espécies em IVI e suas respectivas densidade (De. r), dominância (Do. r) e freqüência relativas (Fr. r) na floresta da Estação Ecológica dos Caetetus. Amostragem pelo método de parcelas

A ordem das espécies, considerando-se a dominância absoluta, apresenta-se ligeiramente invertida em algumas espécies, se comparada com aquela do IVI. $M$. nigra aparece em primeiro lugar com 4,66 $\mathrm{m}^{2} \mathrm{ha}^{-1}$, seguida por A. polyneuron com $3,14 \mathrm{~m}^{2} \mathrm{ha}^{-1}$, O. indecora com $2,40 \mathrm{~m}^{2} \mathrm{ha}^{-1}$, G. integrifolia com $2,47 \mathrm{~m}^{2} \mathrm{ha}^{-1}$, C. tomentosum com $1,54 \mathrm{~m}^{2} \mathrm{ha}^{-1}$, S. romanzoffiana com $1,28 \mathrm{~m}^{2} \mathrm{ha}^{-1}$ e B. riedelianum $1,27 \mathrm{~m}^{2} \mathrm{há}^{-1}$. As outras 133 espécies amostradas apresentam dominância absoluta menor do que $1 \mathrm{~m}^{2} / \mathrm{ha}$.

As espécies que mais se destacaram, com altos valores de Índice de Valor de Cobertura (IVCs) são as mesmas que se destacaram em IVI, com a troca em algumas posições. Em ordem decrescente de IVC, as dez primeiras espécies são: $M$. nigra $(63,64), A$. polyneuron $(16,35)$, O. indecora $(11,85), G$. integrifolia $(9,72), C$. 
tomentosum $(8,29)$, B. riedelianum $(7,21)$, S. romanzoffiana $(6,96)$, T. catigua $(5,17), C$. floribundus $(3,89)$ e C. gonocarpum $(3,40)$.

No Anexo 4 estão listadas as 95 espécies amostradas no levantamento pelo método de quadrantes, com os seus respectivos parâmetros fitossociológicos e valores de volumes absoluto e relativo. Os dados estão classificados por ordem decrescente de Índice de Valor de Importância (ivi).

A Metrodorea nigra foi a espécie que apresentou o maior valor de IVI $(94,16)$. Com o índice bem mais baixo estão as seguintes espécies: Ocotea indecora com 24,05; Aspidosperma polyneuron com 22,46; Trichilia catigua com 10,90; Centrolobium tomentosum com 10,79; Syagrus romanzoffiana com 10,29; Balfourodendron riedelianum com 10,14; Gallesia integrifolia com 9,35; Chrysophyllum gonocarpum com 6,29 e Croton floribundus com 4,97. Essas espécies somaram 67,80\% do IVI total e as 85 espécies restantes representaram $32,20 \%$ do IVI total. 56 espécies apresentaram IVIs até 1 e representam $58,95 \%$ do total de espécies amostradas, somando $7,20 \%$ do IVI total. A Figura 16 apresenta a distribuição das 10 principais espécies em IVI e respectivas densidade, dominância e frequência relativas, obtidos por quadrantes.

Nenhuma espécie foi observada em todos os pontos. A espécie de maior freqüência absoluta foi $M$. nigra (88,44\%), seguida de $A$. polyneuron $(19,06 \%), O$. indecora $(18,44 \%)$, T. catigua $(16,56 \%)$, S. romanzoffiana $(11,25 \%)$ e B. riedelianum $(10,31 \%)$

A densidade absoluta totalizou 1099,23 indivíduos por hectares, com Intervalo de Confiança de $95 \%(1041 ; 1161)$. As espécies que apresentaram as maiores densidades absolutas foram M. nigra (527 ind/ha), A. polyneuron (57 ind/ha), O. indecora (56 $\mathrm{ind} / \mathrm{ha})$, C. tomentosum (47 ind/ha), S. romanzoffiana (33 ind/ha) e B. riedelianum com 30 indivíduos por hectare. ).

Quanto à dominância absoluta, Metrodorea nigra apresentou o maior valor com $4,68 \mathrm{~m}^{2} \cdot \mathrm{ha}^{-1}$., com pequena diferença em relação à $O$. indecora $\left(3,85 \mathrm{~m}^{2} \cdot \mathrm{ha}^{-1}\right)$ e $A$. polyneuron $\left(3,27 \mathrm{~m}^{2} \cdot \mathrm{ha}^{-1}\right)$. Em seguida, com maior diferença, aparecem $G$. integrifolia com $2,00 \mathrm{~m}^{2} \cdot \mathrm{ha}^{-1}$, C. tomentosum com $1,33 \mathrm{~m}^{2} \cdot \mathrm{ha}^{-1}$, Ficus $s p$. com $1,32 \mathrm{~m}^{2} \cdot \mathrm{ha}^{-1}$ e $S$. 
romanzoffiana com $1,22 \mathrm{~m}^{2} \cdot \mathrm{ha}^{-1}$. As outras 88 espécies amostradas apresentam dominância absoluta menor do que $1 \mathrm{~m}^{2} / \mathrm{ha}$ : A área basal total foi de $31,04 \mathrm{~m}^{2} \mathrm{ha}^{-1}$

As espécies que se destacaram em. valor de cobertura são praticamente as mesmas, com algumas inversões nas posições. $M$. nigra com ivc $=63,09$, O. indecora com ivc $=17,57$, A. polyneuron com ivc $=15,76$, G integrifolia aparece com ivc $=8,05$, $S$. romanzoffiana $\mathrm{com}$ ivc $=6,95, C$. tomentosum $\mathrm{com}$ ivc $=6,89$, B. riedelianum com ivc $=5,73, T$. catigua com ivc $=4,97$, Ficus $s p$. Ivc $=4,43$ e $C$ gonocarpum com ivc $=$ 3.99. Juntas, essas espécies representam 68,71\% do IVC total. Nessa listas, ao contrário daquela do Índice de Valor de Importância, não aparece a espécie Croton floribundus qual cedeu espaço para Ficus sp., com apenas duas árvores de diâmetros avantajados, contribuindo para sua dominância no IVC.

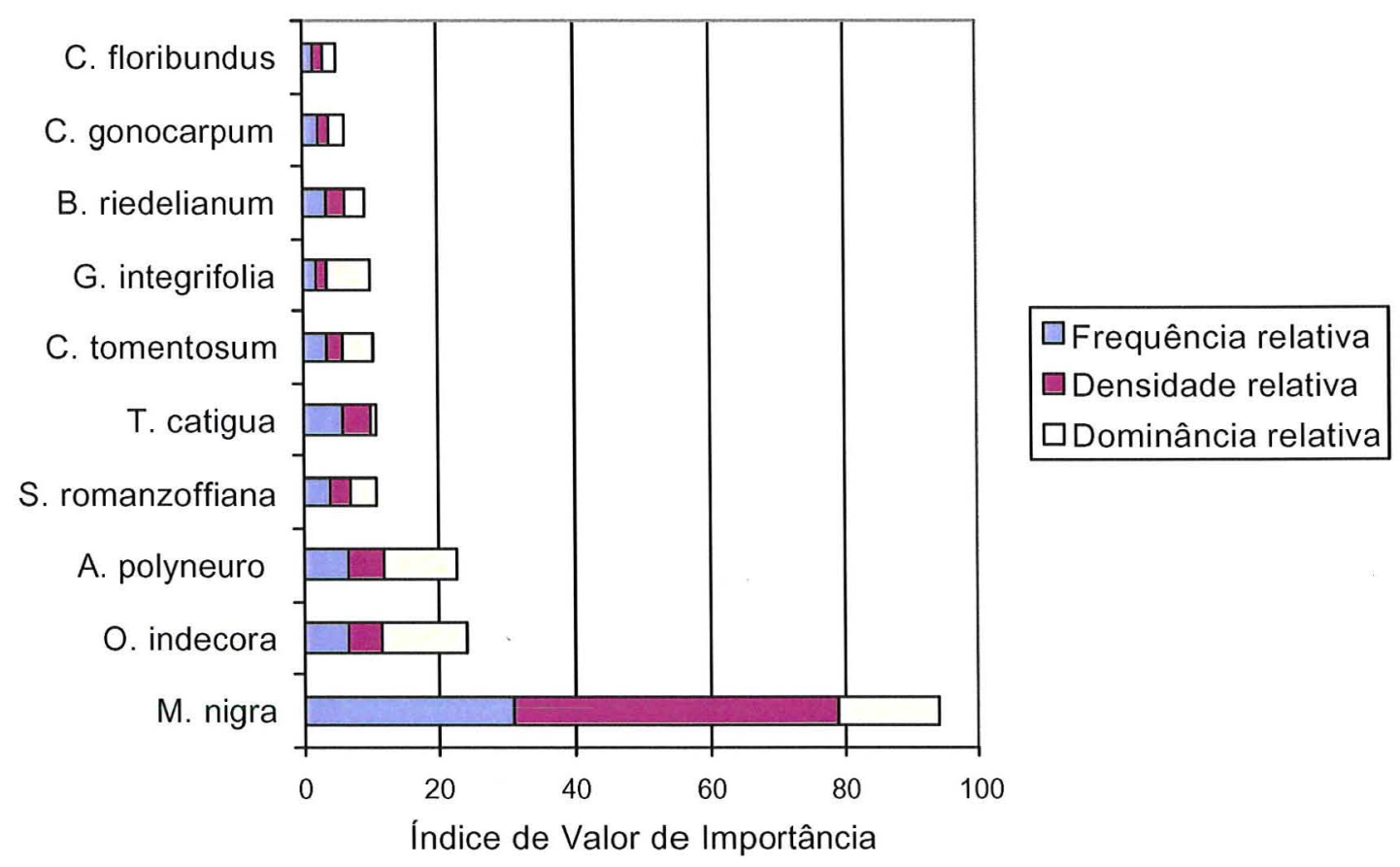

Figura 16 - Distribuição das 10 principais espécies em IVI e suas respectivas densidade, dominância e frequência relativas na floresta da Estação Ecológica dos Caetetus. Amostragem pelo método de quadrantes 
Considerando-se os parâmetros fitossociológicos e observando-se as figuras $15 \mathrm{e}$ 16, nota-se que as 10 espécies de maior IVI nos dois métodos, são as mesmas, porém com algumas alterações de posicionamento. A espécie $M$. nigra sobressaiu-se pela alta densidade relativa e por apresentar freqüência relativa também elevada.

Ainda sobre as espécies de maior importância, pelos dois métodos, Croton floribundus foi a única pioneira a se destacar no grupo dos 10 maiores IVIs. De acordo com Nascimento et al. (2002), as espécies pioneiras são as primeiras a se beneficiarem de perturbações e poucas delas continuam a exercer um alto grau de dominância local.

A Tabela 4 apresenta a participação dos indivíduos dos grupos ecológicos na composição dos índices de valor de cobertura e de importância, nos dois métodos aplicados. Observa-se, que em termos percentuais, as espécies foram amostradas com pequenas diferenças para o Índice de Valor de Importância, aparecendo com maior valor, apenas para as espécies umbrófilas (U), no método de quadrantes. As espécies mais tardias $(\mathrm{U}+\mathrm{UH})$ representam a maioria, onde os seus indivíduos participam com IVI $=184,41$ ou $61,37 \%$ obtidos nas parcelas e 199,24 ou $66,41 \%$ do IVI total obtido nos quadrantes. Esses mesmos indivíduos representam 128,69 ou $64,34 \%$ do IVC total nas parcelas e 129,10 ou 64,55\% nos quadrantes. Para Ivanauskas e Rodrigues (2000), a constatação de espécies finais da sucessão entre as de maior valor de importância e a diminuição desta importância para as espécies pioneiras na estrutura da comunidade seriam indicativos de que a floresta está se regenerando.

A Metrodorea nigra é reconhecidamente uma espécie umbrófila, característica de sub-bosque. Entretanto, na floresta estudada, a alta competição por espaço no estrato inferior e a boa adaptação ao ambiente, está fazendo com a $M$. nigra ocupe posições no estrado médio e até no dossel, observando-se indivíduos dessa espécie com diâmetros acima de $25 \mathrm{~cm}$. Este fato é indicativo de que apesar de se tratar de uma comunidade madura, a floresta estudada está passando por modificações estruturais. 
Tabela 4. Participação dos grupos ecológicos na composição dos índices de Valor de Cobertura (IVC) e Valor de Importância (IVI), na floresta da Estação Ecológica dos Caetetus - Gália, SP

\begin{tabular}{c|cccc|cccc}
\cline { 2 - 9 } & \multicolumn{4}{|c|}{ Método de Parcelas } & \multicolumn{4}{c}{ Método de Quadrantes } \\
\hline GE & IVC & $\%$ & IVI & $\%$ & IVC & $\%$ & IVI & $\%$ \\
P & 8,35 & 4,17 & 16,26 & 5,42 & 8,22 & 4,11 & 12,94 & 4,31 \\
H & 59,04 & 29,52 & 91,99 & 30,66 & 56,82 & 28,41 & 80,75 & 26,92 \\
U & 96,03 & 48,01 & 127,88 & 42,63 & 99,94 & 49,97 & 154,93 & 51,64 \\
UH & 33,26 & 16,63 & 56,23 & 18,74 & 29,16 & 14,58 & 44,31 & 14,77 \\
S/c & 3,92 & 1,96 & 7,63 & 2,54 & 2,93 & 1,46 & 7,09 & 2,36 \\
\hline
\end{tabular}

\subsection{Perfilhamento}

Dos 7520 indivíduos amostrados nas parcelas, 6,71\% (505) apresentaram perfilhamento, representados por 51 ou $36,43 \%$ do total de espécies. As espécies que apresentaram altas taxas dessa característica foram: Metrodorea nigra, com 288 ou $8,42 \%$ dos seus indivíduos, com 2 a 4 perfilhos (fustes) e Ocotea indecora, com 266 ou $41,35 \%$ dos indivíduos, com 2 a 7 perfilhos.

No método de quadrantes, dos 1280 indivíduos amostrados, 7,42\% apresentaramse perfilhados. Entretanto, apesar desse percentual ser maior, se comparado com os indivíduos amostrados pelo método de parcelas, representaram apenas 21 ou $22,10 \%$ das espécies encontradas. Metrodorea nigra e Ocotea indecora foram as espécies que apresentaram as maiores taxas de perfilhamento, com 8,03\% (49 indivíduos) e $38,46 \%$ (25 indivíduos) respectivamente.

Estas duas espécies se sobressaíram nos dois métodos aplicados, fazendo parte das 10 espécies de maiores IVIs. As altas taxas de perfilhamento certamente influenciaram na obtenção da dominância, uma vez que essa característica é formada pela soma das áreas basais dos fustes (perfilhos). Nos quadrantes, onde foram amostrados menos indivíduos, essa característica foi mais determinante para a espécie $O$. indecora. 
Mantovani (1993) em estudos realizados na floresta atlântica na Juréia, município de Iguape, encontrou 3,25\% de indivíduos perfilhados.

Os dados do presente estudo corroboram com aqueles obtidos por Ivanauskas e Rodrigues (2000), que observaram $31 \%$ de perfilhamento entre os indivíduos arbóreos amostrados em remanescentes de floresta estacional decidual em Piracicaba, indicando que a floresta estacional analisada pode apresentar maior número de espécies com altas taxas de perfilhamento, quando comparada com as florestas estacionais.

Segundo Mantovani (1993), a expansão lateral dos indivíduos e a reprodução vegetativa são estratégias vantajosas, em ambientes onde a competição por espaço é intensa. Entre os fatores apontados como capazes de favorecer as ramificações, até a abertura de clareiras, com mudanças no microclima, principalmente o aumento da luminosidade. No presente estudo, as duas espécies que mais apresentaram indivíduos perfilhados são características de sub-bosque e possuem o hábito de crescimento entouceirado, ramificando-se naturalmente.

\subsection{Distribuição da Freqüência de árvores por classes de DAP}

Segundo Machado et al. (1982), o conhecimento da estrutura diamétrica de uma floresta é de grande importância para a tomada de decisão quanto ao manejo e aproveitamento das mesmas. Esta importância torna-se ainda maior em caso de florestas tropicais multiâneas e heterogêneas, onde a variável idade é de dificil obtenção, além de apresentar valor relativo devido à sua ampla va riação.

A distribuição diamétrica é uma característica importante do estoque atual e em crescimento.

A Figura 17 apresenta a distribuição de frequiência de árvores por classes de diâmetro, obtida pelo método de parcelas. Nota-se, para a vegetação de uma maneira geral, a alta freqüência de indivíduos de diâmetros pequenos e quase ausência de indivíduos com diâmetros superiores a $35 \mathrm{~cm}$. A distribuição diamétrica da comunidade estudada, segue o modelo de " $\mathrm{j}$ " invertido, comum em florestas tropicais. 
Verifica-se que a primeira classe apresentou a maior quantidade com $56,41 \%$ do total ou 4032 indivíduos. Se somada com a segunda classe, com 18,99\% (1357) indivíduos e a terceira classe com 9,09\% (650) do total, perfazem $84,49 \%$ das árvores amostradas. A última classe correspondente a árvores maiores do que $85 \mathrm{~cm}$, apresentou 14 indivíduos $(0,19 \%)$. O maior DAP $(1,68 \mathrm{~m})$, foi registrado para uma árvore de Gallesia integrifolia. Apenas $15,51 \%$ dos indivíduos amostrados possuem DAP viável para processamento mecânico.

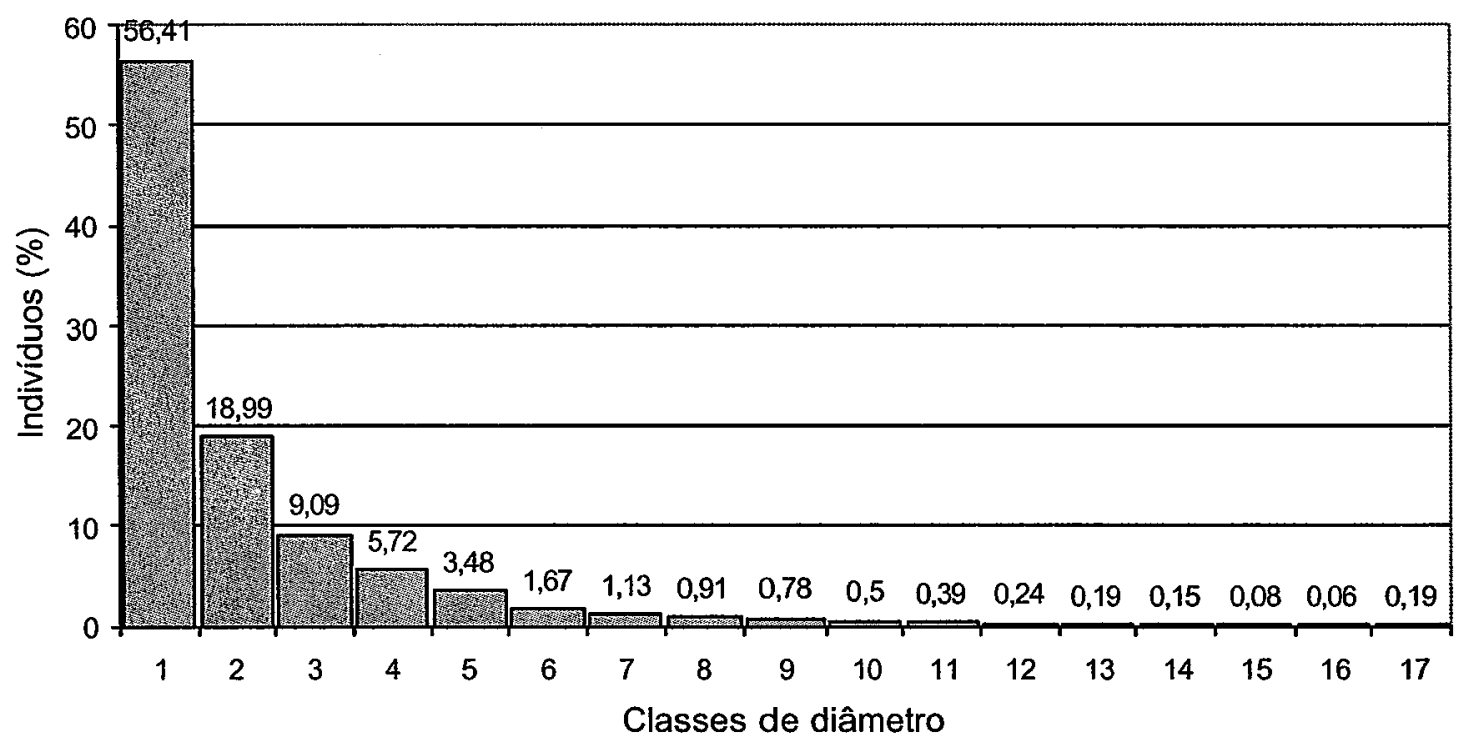

Figura 17 - Freqüência de árvores vivas (\%) por classes de diâmetro obtidas pelo método de parcelas, na floresta da Estação Ecológica dos Caetetus - Gália, SP. 1 = classe de 5,0 a $10,0 \mathrm{~cm}, 2=$ classe de 10,1 a $15 \mathrm{~cm}, 3=$ classe de $15,1 \mathrm{~cm}$ a $20 \mathrm{~cm}, \ldots . . .16=$ classe de 80,1 a $85 \mathrm{~cm}$ e $17=$ classes maiores que $85,1 \mathrm{~cm}$

Na Figura 18 é apresentada a distribuição de freqüência de árvores por classes de diâmetro obtidas pelo método dos quadrantes. Observa-se que a primeira classe apresentou a maior quantidade de indivíduos, com 53,54\% (681) do total e se somados 
com a segunda e a terceira classe, perfazem $81,76 \%$ (1040) das árvores amostradas. A última classe compreendendo árvores maiores do que $75,1 \mathrm{~cm}$ de DAP, apresentou 7 indivíduos. O maior DAP fi de 1,39m, registrado para uma árvore de Ficus sp.18,24\% dos indivíduos amostrados possuem DAP viável para processamento em serrarias.

Nota-se que, da mesma forma que nas parcelas, a distribuição diamétrica da comunidade estudada, segundo o resultado do método de quadrantes, segue o modelo de “j” invertido, comum em florestas tropicais.

Tanto na amostragem pelo método de parcelas, como de quadrantes, populações numerosas, como Metrodorea nigra, Ocotea indecora e Trichilia catigua, por sua forma de crescimento e por serem espécies características dos estratos inferiores, contribuíram para o destaque das duas primeiras classes de diâmetro (até $15 \mathrm{~cm}$ ).

A comparação dos dados das figuras de distribuição de frequiência de classes de diâmetro (Figuras 17 e 18), com aquelas formadas pela quantidade de indivíduos que compõem os estratos da floresta (Figura 12), confirma a existência de muitos indivíduos, no sub-bosque.

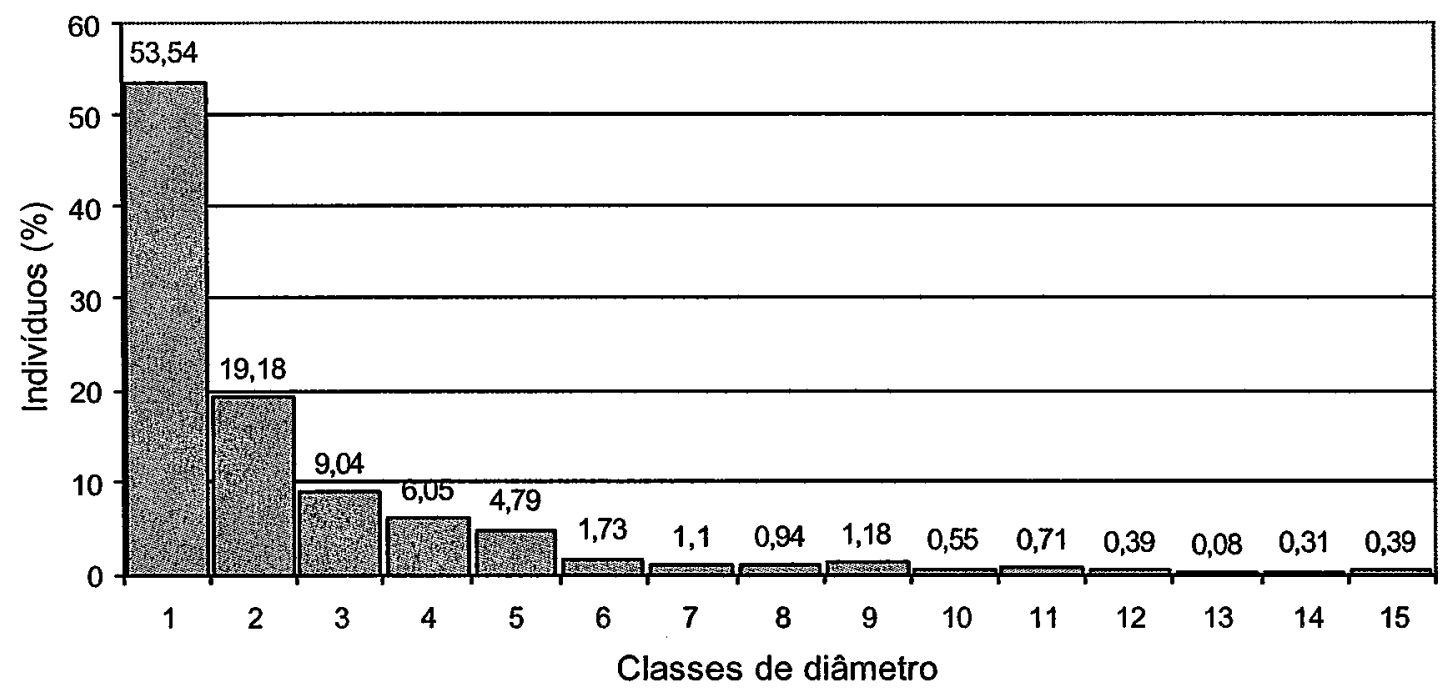

Figura 18 - Freqüência de árvores vivas (\%) por classes de diâmetro obtidas pelo método de quadrantes, na floresta da Estação Ecológica dos Caetetus - Gália, SP. 1 = classe de 5,0 a $10,0 \mathrm{~cm}, 2=$ classe de 10,1 a $15 \mathrm{~cm}, 3=$ classe de $15,1 \mathrm{~cm}$ a $20 \mathrm{~cm}, \ldots . . .14=$ classe de 70,1 a $75 \mathrm{~cm}$ e $15=$ classes maiores que $75,1 \mathrm{~cm}$ 
Para o enquadramento das espécies, conforme as classes de valor comercial e usos da madeira, tomou-se como base a listagem apresentada pelo perito judicial em seu relatório que instruiu o processo de desapropriação da área que hoje é ocupara pela Estação Ecológica dos Caetetus. Cabe ressaltar que nessa listagem, constam somente nomes populares, o que limitou comparação da classificação das espécies encontradas no presente estudo, com as espécies daquele laudo.

Assim, em ambos os métodos, as espécies de madeiras de classe I amostradas foram: Centrolobium tomentosum, Myroxylon peruiferum, Cedrela fissilis, Patagonula americana, Cariniana estrelensis e Aspidosperma polyneuron.

As espécies de madeira de classe II encontradas foram: Luehea divaricata, Holocalyx balansae, Parapiptadenia rigida, Cabralea canjerana, Peltophorum dubium, Astronium graveolens, Rhamnidium elaeocarpum, Balfourodendron riedelianum e Maclura tinctoria.

Dentre as espécies amostradas, as produtoras de madeira de classe III foram: Alchornea glandulosa, Croton floribundus, Jacaranda micrantha, Albizia haslerii, Zanthoxylum fagara, Gallesia integrifolia, Casearia gossipiosperma, Chorisia speciosa, Machaerium nictitans, Machaerium stipitatum e Lonchocarpus cultratus.

Nas Figuras 19 a 23 são apresentadas as distribuições de freqüências de árvores por classes diamétricas das espécies consideradas classe I, e que foram amostradas com 20 ou mais indivíduos, nas amostragens por parcelas e quadrantes,

Nas parcelas, Aspidosperma polyneuron (peroba-rosa) foi dbservada em todas as unidades amostrais. Os seus 408 indivíduos amostrados distribuíram-se em 16 classes de diâmetro, que são apresentadas na Figura 19. Esta espécie apresenta em sua freqüência de classes de diâmetro, curva vista como uma série geométrica decrescente, caracterizado pelo maior número de jovens, seguindo o padrão da comunidade. A maior parte dos indivíduos dessa espécie aparece nas duas primeiras classes, onde 294 representam $72,06 \%$ do total de indivíduos amostrados. A última classe no gráfico é representada por 6 indivíduos, com o maior deles apresentando DAP $=1,19 \mathrm{~m}$. Como mencionado anteriormente, considerou-se neste trabalho, o diâmetro de $20 \mathrm{~cm}$ como o 
limite para o processamento mecânico em serrarias. Assim, apenas $19,36 \%$ dos fustes amostrados para a peroba apresentam DAPs viáveis para serrar.

Nos quadrantes, os 66 indivíduos de peroba, se distribuíram em 11 classes de diâmetro (Figura 20). A maior parte dos indivíduos apareceu na primeira classe $(45,45 \%$ do total), apresentando oscilações entre as outras. Essa oscilação pode dar indicação de: reprodução em pulsos, que representam periodos mais ou menos favoráveis à sobrevivência e ao recrutamento, desenvolvimento diferenciado dos indivíduos da população em determinadas etapas do ciclo de vida, quando ocorrem taxas de crescimento distintas ou, ainda, ser resposta ao pequeno número de indivíduos amostrados dessa população, o que é mais provável. A última classe é representada por 5 indivíduos, sendo o maior deles, com DAP $=0,63 \mathrm{~m}$. Pó este método, 37,88\%dos indivíduos apresentam fustes com DAP viável paras processamento (serraria).

Considerando-se a amostragem da população de peroba feita pelo método das parcelas (Figura 19) como aquela que reflete a realidade da floresta, uma vez que avaliou o comportamento da espécie em 5,76 hectares da floresta, observa-se que está havendo reposição, mesmo que lenta, dos indivíduos das classes de diâmetros maiores, sem oscilação. A pequena quantidade de indivíduos mais velhos pode indicar que houve interferência antrópica na área, ou que a espécie apresenta dificuldade para resistir os fortes ventos esporádicos incidentes na região.

Schlittler (1990), em seu trabalho de levantamento realizado na floresta do Parque Estadual do Morro do Diabo, encontrou para a espécie A. polyneuron uma distribuição bem diferente, com ausência de indivíduos jovens, grande interrupção nas classes médias e predominância em apenas uma classe alta. $O$ autor associa este quadro, a uma ausência de renovação na população, confirmando observações de campo. Pagano et al. (1987), em área preservada em Rio Claro, encontrou um número bem mais elevado de indivíduos jovens (pertencentes a primeira e segunda classes) na população de $A$. polyneuron.

Segundo Daubenmire (1968) apud Silva e Soares (1999), comunidade climácica é aquela que mantém posse permanente do ambiente, já que, quando uma planta envelhece e morre, uma outra imediatamente mais jovem, deve substituí-la. Dessa 
maneira, deve-se esperar uma série completa de classes de diâmetro para cada uma das espécies que compõem a comunidade. Quando a série de classes é interrompida ou truncada em qualquer dos extremos, o ciclo de vida pode não estar se completando e a espécie, geralmente, não pode ser considerada como em equilíbrio no ambiente. Assim, deve-se esperar para as populações em equilíbrio, histogramas de frequência de classes de diâmetro como uma série decrescente, inversamente a um aumento no diâmetro do caule.

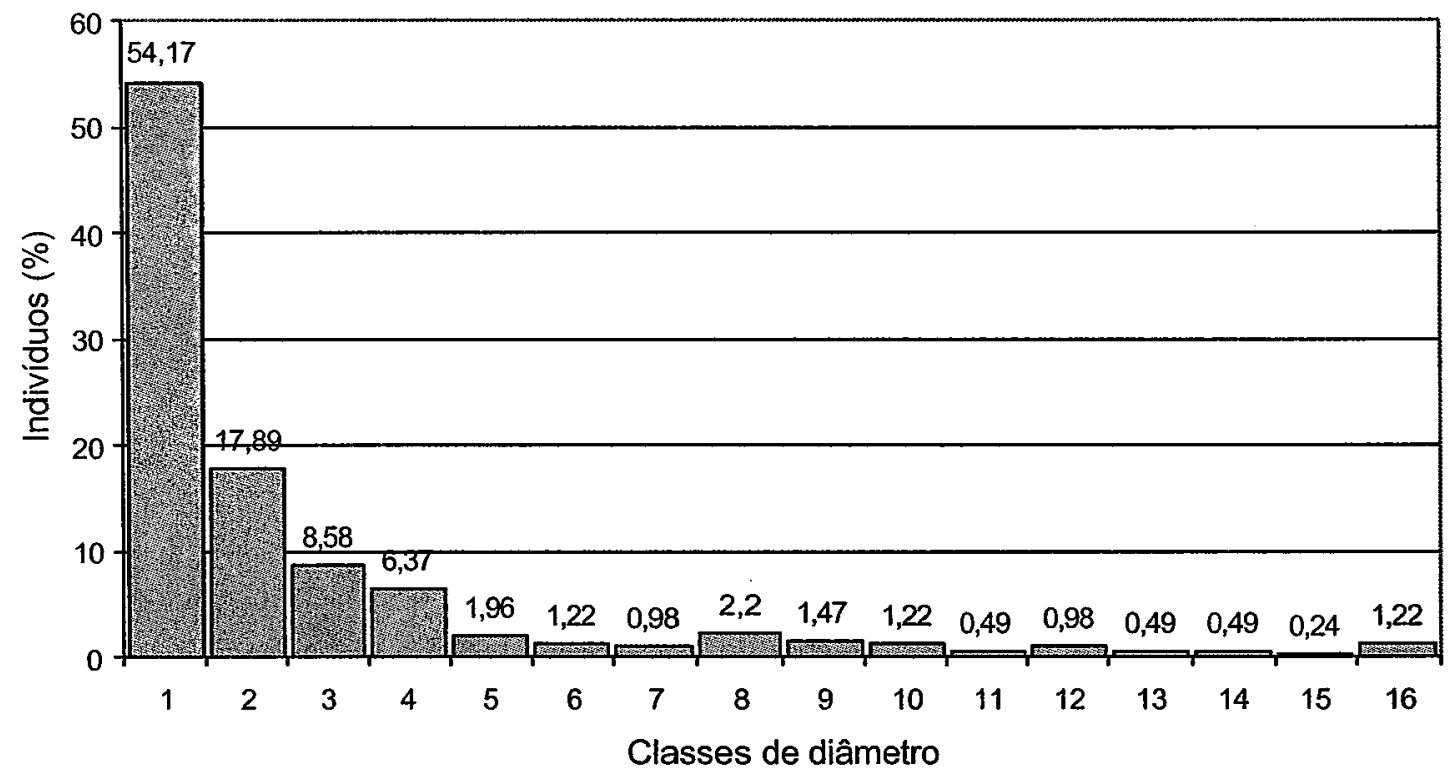

Figura 19 - Freqüência de árvores por classes de diâmetro de Aspidosperma polyneuron, amostradas pelo método de parcelas, na floresta da Estação Ecológica dos Caetetus - Gália, SP. 1 = classe de 5,0 a 10,0cm, 2 = classe de 10,1 a $15 \mathrm{~cm}$, $3=$ classe de $15,1 \mathrm{~cm}$ a $20 \mathrm{~cm}, \ldots . .15=$ classe de 75,1 a $80 \mathrm{~cm}$ e $16=$ classes maiores que $80,1 \mathrm{~cm}$ 


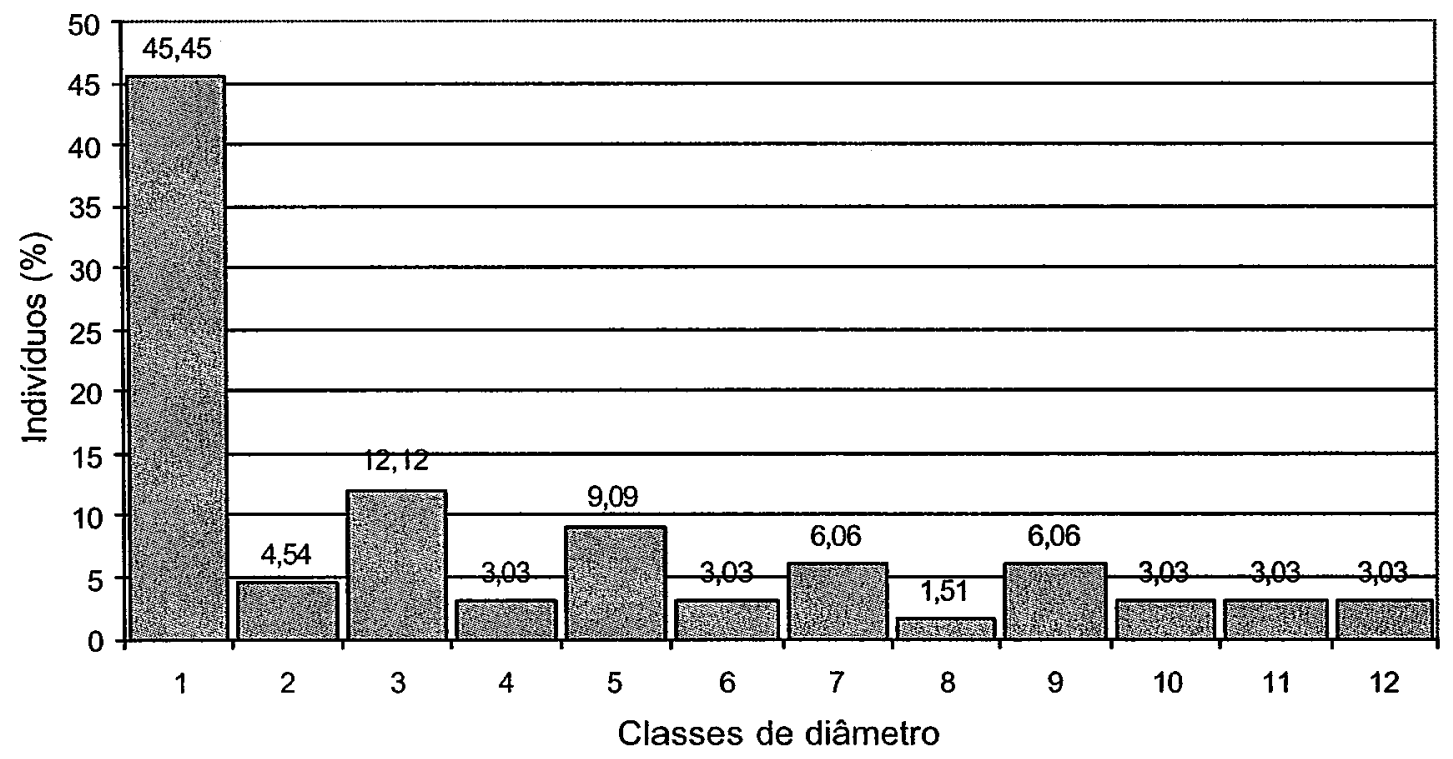

Figura 20 - Freqüência de árvores por classes de diâmetro de Aspidosperma polyneuron, amostradas pelo método de quadrantes, na floresta da Estação Ecológica dos Caetetus - Gália, SP. 1 = classe de 5,0 a 10,0cm, 2 = classe de 10,1 a $15 \mathrm{~cm}, 3=$ classe de $15,1 \mathrm{~cm}$ a $20 \mathrm{~cm}, \ldots . .10=$ classe de 50,1 a $55,0 \mathrm{~cm}$ e 11 $=$ classes maiores que $55,1 \mathrm{~cm}$

As árvores de Centrolobium tomentosum (araribá), representaram o quinto maior IVI, pelo método das parcelas. Os 221 indivíduos amostrados distribuíram-se em 10 classes de diâmetro, apresentadas na Figura 21, onde pode-se observar que apresenta curva exponencial negativa, caracterizada pelo número maior de jovens. 90 indivíduos aparecem nas duas primeiras classes, representando $43,48 \%$ do total amostrado. A última classe no gráfico é representada por 3 indivíduos, com o maior deles apresentando DAP $=0,51 \mathrm{~m}$. Do total,

Nos quadrantes, o araribá, com seus 33 indivíduos, distribuiu-se em 8 classes, apresentadas na Figura 22, podendo-se observar que 51,51\% do total de indivíduos amostrados pertencem às 3 primeiras classes de diâmetro. A última classe é representada por dois indivíduos, com o maior deles apresentando DAP $=0,5 \mathrm{~m} .48,49 \%$ dos fustes dessa espécie apresentam DAPs viáveis para o processamento mecânico. 


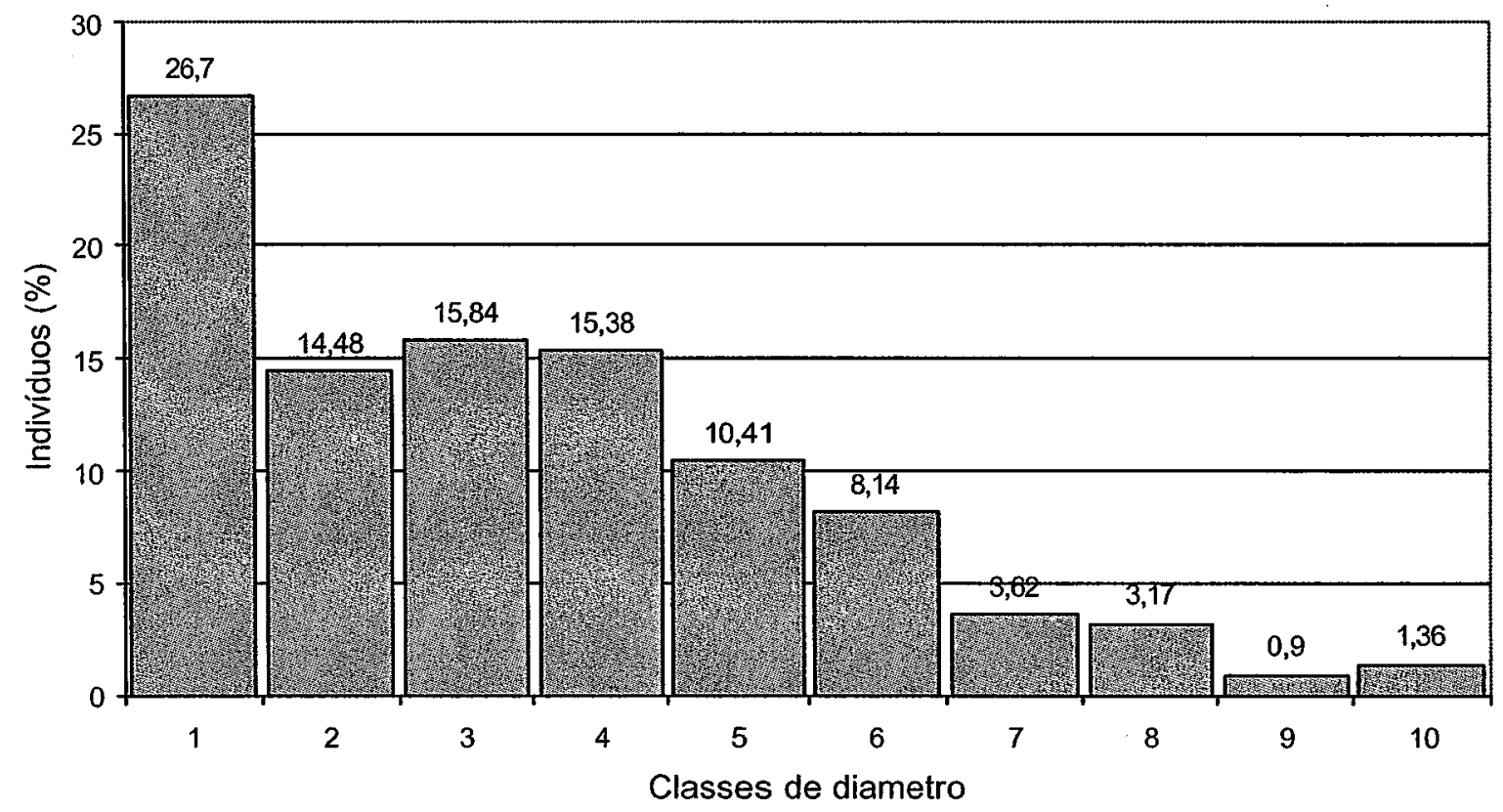

Figura 21 - Freqüência de árvores por classes de diâmetro de Centrolobium tomentosum, amostradas pelo método de parcelas, na floresta da Estação Ecológica dos Caetetus - Gália, SP. $1=$ classe de 5,0 a 10,0 cm, $2=$ classe de 10,1 a $15 \mathrm{~cm}$, $3=$ classe de $15,1 \mathrm{~cm}$ a $20 \mathrm{~cm}, \ldots . . .9=$ classe de 45,1 a $50 \mathrm{~cm}$ e $10=$ classes maiores que $50,1 \mathrm{~cm}$ 


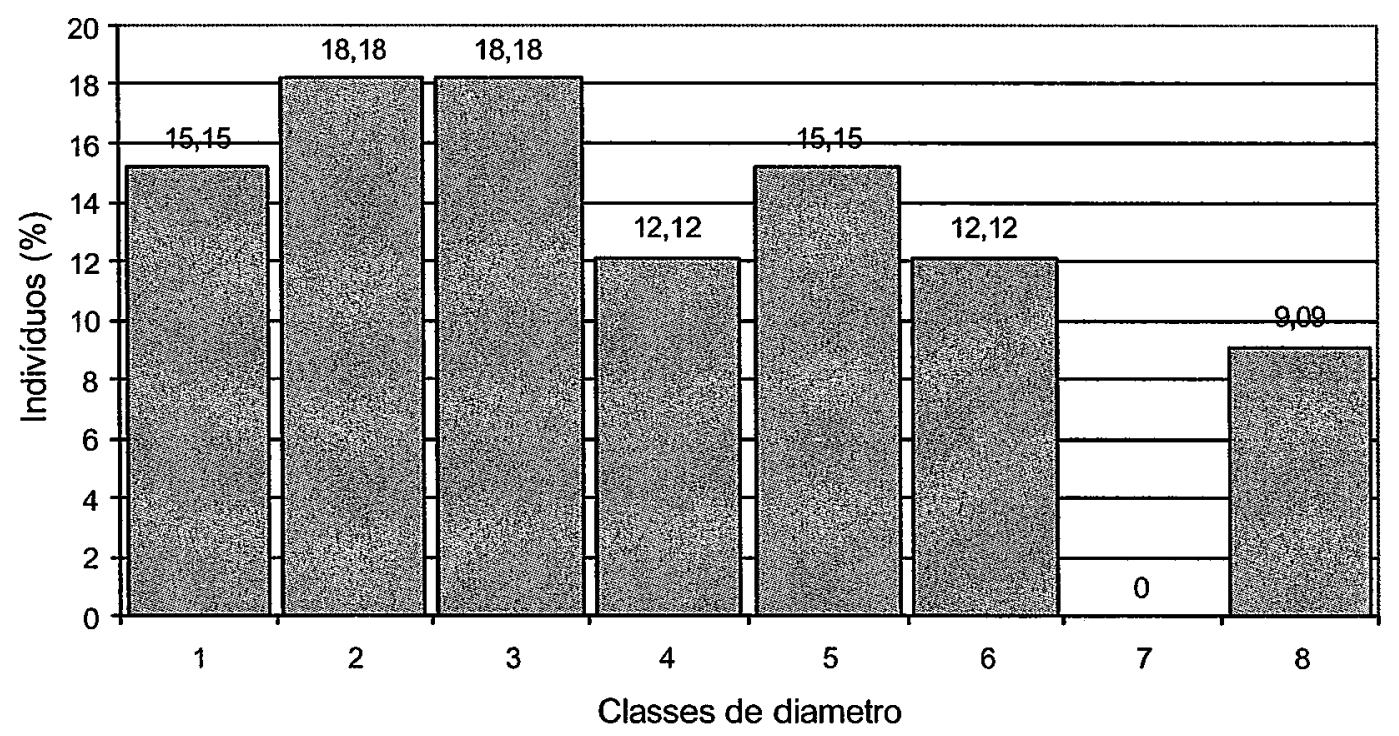

Figura 22 - Freqüência de árvores por classes de diâmetro de Centrolobium tomentosum, amostradas pelo método de parcelas, na floresta da Estação Ecológica dos Caetetus - Gália, SP. $1=$ classe de 5,0 a 10,0cm, $2=$ classe de 10,1 a $15 \mathrm{~cm}$, $3=$ classe de $15,1 \mathrm{~cm}$ a $20 \mathrm{~cm}, \ldots . .7=$ classe de 35,1 a $40 \mathrm{~cm}$ e $8=$ classes maiores que $40,1 \mathrm{~cm}$

Para os dois métodos aplicados, os histogramas de freqüência de classes de diâmetro apresentam o $C$. tomentosum com boa capacidade de regeneração na área, o que pode ser percebido com a maior quantidade de indivíduos de menores diâmetros. Entretanto, pode ser indicação de que a espécie apresenta dificuldade no estabelecimento dos indivíduos de maior diâmetro da população.

O cedro-rosa (Cedrela fissilis), com seus 36 indivíduos amostrados nas parcelas (Figura 23), foi a vigésima quinta espécie na ordem decrescente de Índice de Valor de Importância. Seus indivíduos distribuíram-se em 7 classes de diâmetro, sendo que 21 indivíduos deles apareceram nas três primeiras classes, representando $58,33 \%$ do total amostrado. Entretanto, há menos indivíduos na primeira classe, o que pode indicar, épocas com menor reposição. A sua densidade absoluta $\left(6,25\right.$ ind $\left.\mathrm{ha}^{-1}\right)$, aponta para uma população em equilíbrio, pois em populações de cedro com muito mais do que 5 
indivíduos por hectare, essa espécie torna-se vulnerável ao ataque de insetos xilófagos (Hypsipyla sp). A última classe no gráfico é representada por 3 indivíduos, com o maior deles apresentando DAP $=0,51 \mathrm{~m} .41,67 \%$ dos fustes apresentam DAPs viáveis para o processamento mecânico.

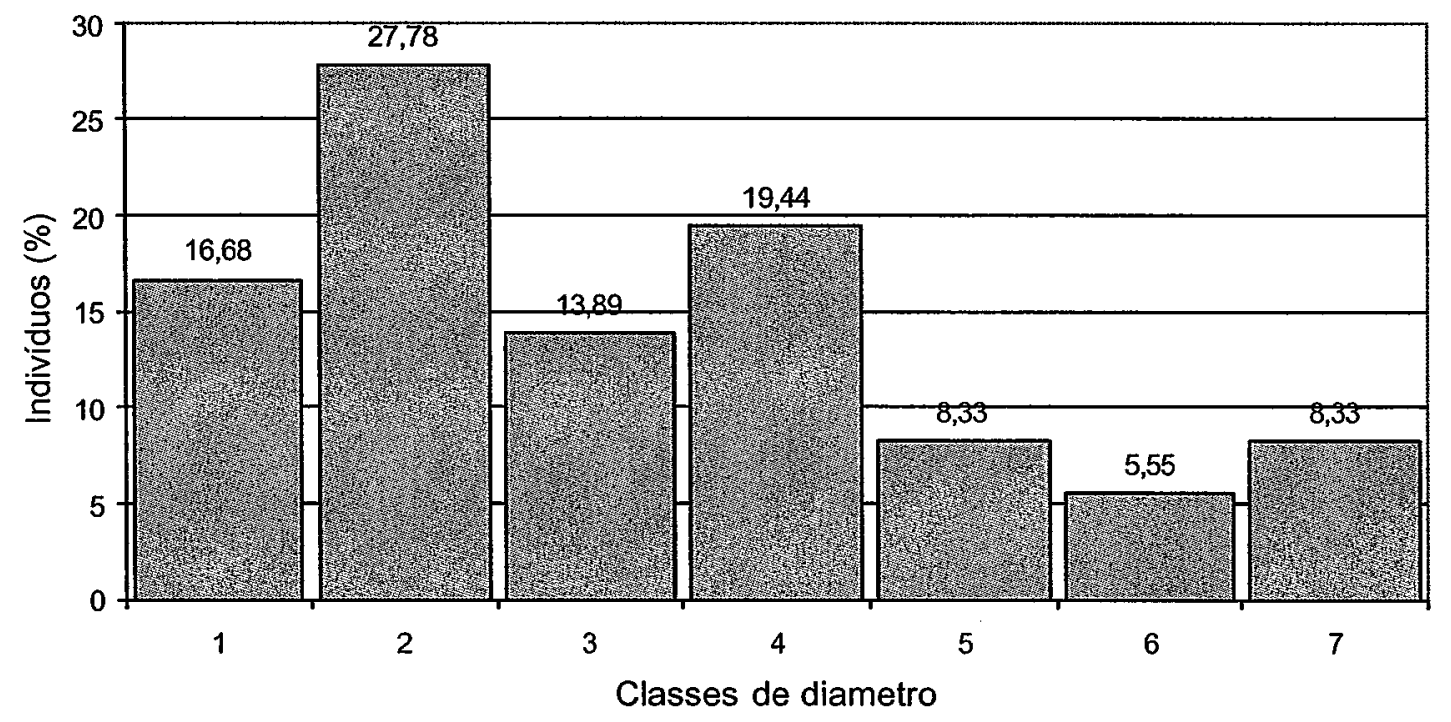

Figura 23 - Frequiência de árvores por classes de diâmetro de Cedrela fissilis, amostradas pelo método de parcelas, na floresta da Estação Ecológica dos Caetetus Gália, SP. $1=$ classe de 5,0 a 10,0 cm, $2=$ classe de 10,1 a $15 \mathrm{~cm}, 3=$ classe de $15,1 \mathrm{~cm}$ a $20 \mathrm{~cm}, \ldots . . .6=$ classe de 30,1 a $35,0 \mathrm{~cm}$ e $7=$ classes maiores que $35,1 \mathrm{~cm}$

\subsection{Volume}

A variável volume constitui uma das informações de maior importância para o conhecimento do potencial florestal disponível em uma região. $\mathrm{O}$ volume individual fornece um ponto de partida para a avaliação do conteúdo lenhoso dos povoamentos (Jorge, 1982). 
Neste estudo, o volume total estimado pelo método de parcelas para a comunidade foi de $170,56 \mathrm{~m}^{3} \mathrm{ha}^{1}( \pm 13,51)$. As espécies que mais se destacaram foram: M. nigra com $19,51 \mathrm{~m}^{3} \mathrm{ha}^{-1}$, A. polyneuron com $18,23 \mathrm{~m}^{3} \mathrm{ha}^{-1}$, G. integrifólia com $14,98 \mathrm{~m}^{3} \mathrm{ha}^{-1}$, O. indecora com $12,79 \mathrm{~m}^{3} \mathrm{ha}^{-1}, C$. tomentosum com $8,38 \mathrm{~m}^{3} \mathrm{ha}^{-1}, B$. riedelianum com $7,073 \mathrm{~m}^{3} \mathrm{ha}^{-1}$, S. romanzoffiana com $6,78 \mathrm{~m}^{3} \mathrm{ha}^{-1}$ e Acácia polyphylla com $4,19 \mathrm{~m}^{3} \mathrm{ha}^{-1}$. Ao serem consideradas apenas estas oito espécies que apresentaram volume maior do que $4 \mathrm{~m}^{3} \mathrm{ha}^{-1}$, elas representaram $93,47 \mathrm{~m}^{3} \mathrm{ha}^{-1}$ ou $54,80 \%$ do volume estimado total (Figura 24).

Quanto ao método de quadrantes, o volume estimado foi de $169,66 \mathrm{~m}^{3} \mathrm{ha}^{-1}$ ( \pm $30,61)$, com o volume médio de $0,154 \mathrm{~m}^{3} \mathrm{ha}^{-1}( \pm 0,026)$. Na Figura 25 estão apresentadas as espécies que se destacaram em volume por este método, sendo elas: $O$. indecora com $21,86 \mathrm{~m}^{3} \mathrm{ha}^{-1} ; M$. nigra com $20,28 \mathrm{~m}^{3} \mathrm{ha}^{-1} ; O$. polyneuron com $18,85 \% \mathrm{~m}^{3} \mathrm{ha}^{-1} ; G$. integrifólia com $11,86 \mathrm{~m}^{3} \mathrm{ha}^{-1}$; Ficus sp. $8,44 \mathrm{~m}^{3} \mathrm{ha}^{-1}$; C. tomentosum com $7,33 \mathrm{~m}^{3} \mathrm{ha}^{-1} ; S$. romanzoffiana com $6,44 \mathrm{~m}^{3} \mathrm{ha}^{-1} ; C$. speciosa com $5,80 \mathrm{~m}^{3} \mathrm{ha}^{-1} ; P$. americana com $5.66 \mathrm{~m}^{3} \mathrm{ha}^{-1} ; P$. gonoacantha com $5,52 \mathrm{~m}^{3} \mathrm{ha}^{-1}$ e B. riedelianum com $5,08 \mathrm{~m}^{3} \mathrm{ha}^{-1}$. As outras 85 espécies apresentaram volume estimado total menor do que $4 \mathrm{~m}^{3} \mathrm{ha}^{-1}$.

As espécies $M$. nigra e $O$. indecora aparecem entre as espécies de maior volume nos dois métodos de amostragem, como resposta à alta taxa de perfilhamento e grande quantidade de indivíduos amostrados de cada uma delas. Pelo método dos quadrantes, a espécies $O$. indecora ocupou posição de destaque com $21,86 \mathrm{~m}^{3} \mathrm{ha} \mathrm{h}^{-1}$, onde, a quantidade de fustes perfilhados influenciaou na obtenção de área basal maior, e assim, resultando no maior volume estimado para a espécie.

A Figura 26 apresenta a distribuição do volume $\mathrm{em} \mathrm{m}^{3} \mathrm{ha}^{-1}$ e percentual dos fustes amostrados pelo método de parcelas, em ralação às classes de diâmetro. Nota-se que as 3 primeiras classes, onde estão $92,62 \%$ ou 6965 fustes com DAPs menores de $20 \mathrm{~cm}$ (estoque de crescimento), representam apenas $23,09 \%$ do volume total estimado. As outras classes, cujos fustes apresentaram DAPs viáveis para processamento em serrarias (estoque de produção), representam $76,91 \%$ do estoque total. Esta mesma tendência foi observada por Heinsdjik e Campos (1967) e Campos e Heinsdjik (1970). 
$\mathrm{O}$ volume do estoque de crescimento das classes de madeira de valor comercial reconhecido no mercado foi de $7,20 \mathrm{~m}^{3} \mathrm{ha}^{-1}$, representando $4,22 \%$ do volume total, enquanto que o estoque de produção foi de $70,82 \mathrm{~m}^{3} \mathrm{ha}^{-1}$ ou $41,52 \%$ do estoque total estimado. As madeiras sem valor comercial, aquelas consideradas como lenha, representaram $92,54 \mathrm{~m}^{3} \mathrm{ha}^{-1}$ ou $54,26 \%$ do volume total estimado para a floresta. A Tabela 5 apresenta os valores de volume estimado para cada classe de valor comercial estudada.

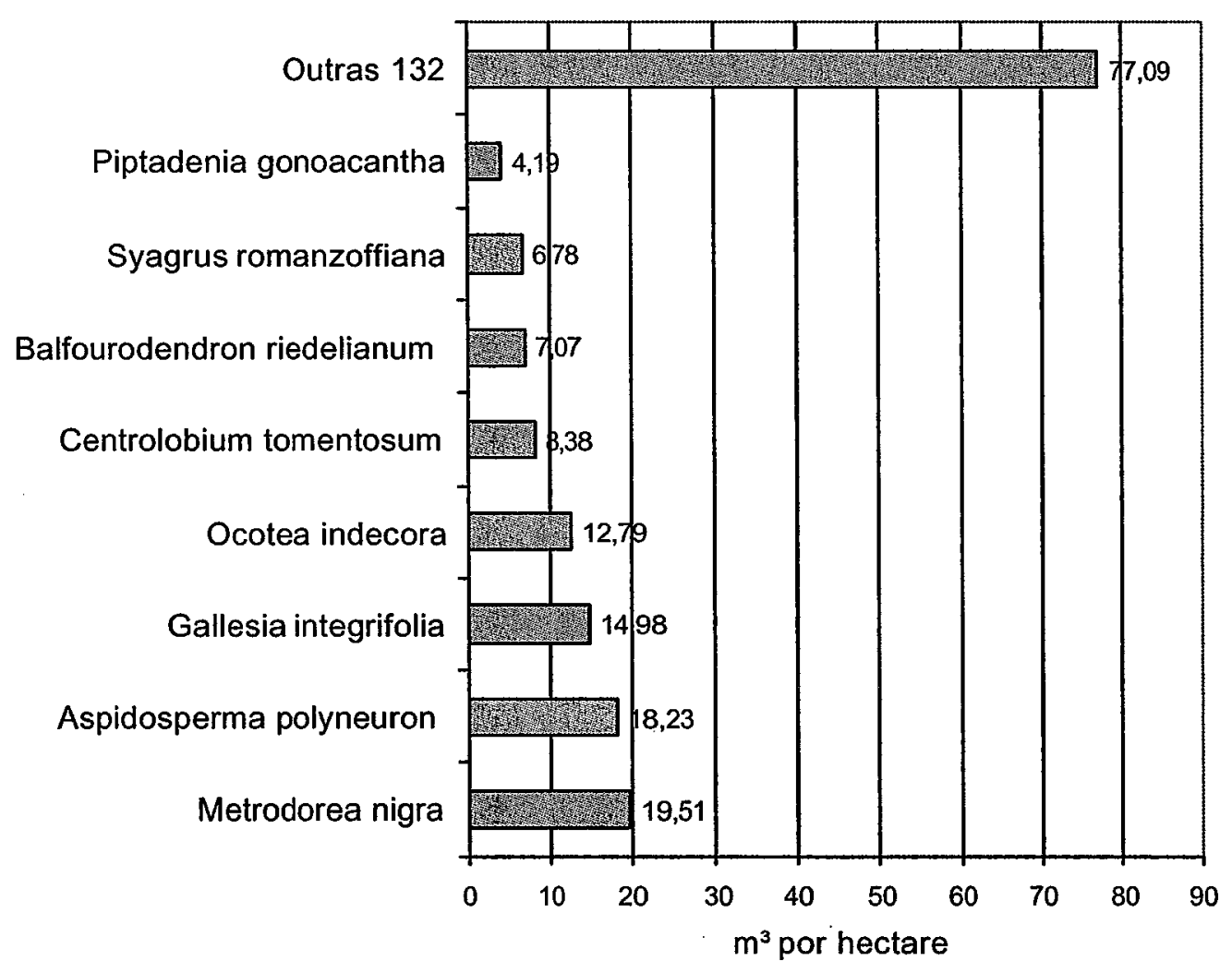

Figura 24 - Participação das principais espécies, na composição do volume estimado total da floresta da Estação Ecológica dos Caetetus - Gália, SP. Método de parcelas 
Considerando-se apenas o estoque de produção para as classes comerciais estudadas, o volume estimado para as madeiras de classe I foi de $32,27 \mathrm{~m}^{3} \mathrm{ha}^{-1}$ ou $18,92 \%$ do total. Para as madeiras de classe II, o volume estimado foi de $17,07 \mathrm{~m}^{3} \mathrm{ha}^{-1}$ ou $10,01 \%$ do estoque total. Estes dados absolutos de volume estão próximos dos estimados por Campos e Heinsdijk (1970), para o tipo florestal com as melhores árvores da floresta estacional semidecidual do Morro do Diabo, cerca de $300 \mathrm{~km}$ distante da área do atual estudo, onde obtiveram $25,37 \mathrm{~m}^{3} \mathrm{ha}^{-1}( \pm 5,89)$ ou $23,20 \%$ de volume de madeira de classe I, e $12,32 \mathrm{~m}^{3} \mathrm{ha}^{-1}( \pm 2,68)$ ou $21,78 \%$ de volume para madeiras de classe II. Cabe salientar, que naquele estudo, os autores consideraram, para a estimativa de volume, apenas as árvores com DAP maiores de $25 \mathrm{~cm}$ e obtiveram o volume sem casca, caso também fossem amostradas as árvores com DAPs maiores do que $20 \mathrm{~cm}$, é possível que esses números fossem mais próximos .

IBDF (1983), estimou em $94,27 \mathrm{~m}^{3} \mathrm{ha}^{-1}$ em média o volume de total de madeira para as áreas de floresta estacional semidecidual do Estado do Paraná. Entretanto, esta estimativa engloba todas as áreas de floresta do mesmo tipo florestal, nos seus diferentes estádios sucessionais. Este mesmo trabalho estimou para os 1.569.400ha de mata do estado de São Paulo, um estoque de $133 \mathrm{~m}^{3}$ de biomassa ou $45 \mathrm{~m}^{3}$ de volume de fuste por hectare. Cabe salientar, que da mesma forma como para o estado do Paraná, os autores consideraram mata, em São Paulo, a soma das áreas de floresta estacional semidecidual com aquelas de floresta ombrófila densa, característica da serra do mar.

Vieira et al. (1989), avaliaram a floresta estacional semidecidual do Parque Estadual da Vassununga e estimaram o estoque total em $194,05 \mathrm{~m}^{3} \mathrm{ha}^{-1}$, entretanto, $18 \%$ $\left(35,04 \mathrm{~m}^{3} \mathrm{ha}^{-1}\right)$ deste foi representado pela espécie Cariniana legalis (jequitibá-rosa), que tem como característica, apresentar grandes indivíduos nas matas daquela região.

Heinsdjik e Campos (1967) encontrou em áreas de floresta ombrófila densa da região de Sete Barras e Capão Bonito, no Estado de São Paulo, o volume total de $120 \mathrm{~m}^{3} \mathrm{ha}^{-1}$, com cerca de $35 \%$ para as madeira de classe I e $16 \%$ para aquelas de classe II. 


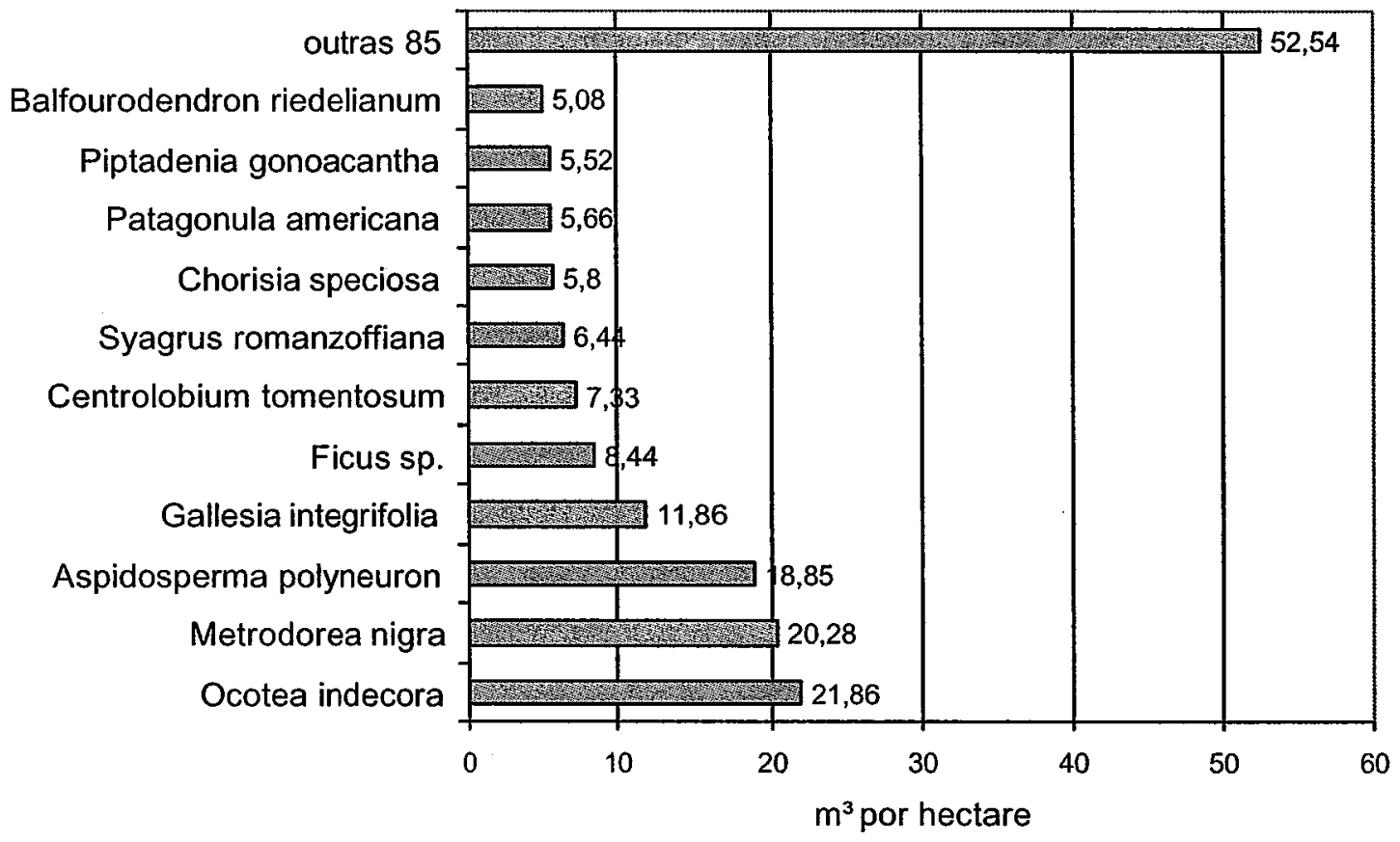

Figura 25 - Participação das principais espécies, na composição do volume total da floresta da Estação Ecológica dos Caetetus - Gália, SP. Método de quadrantes

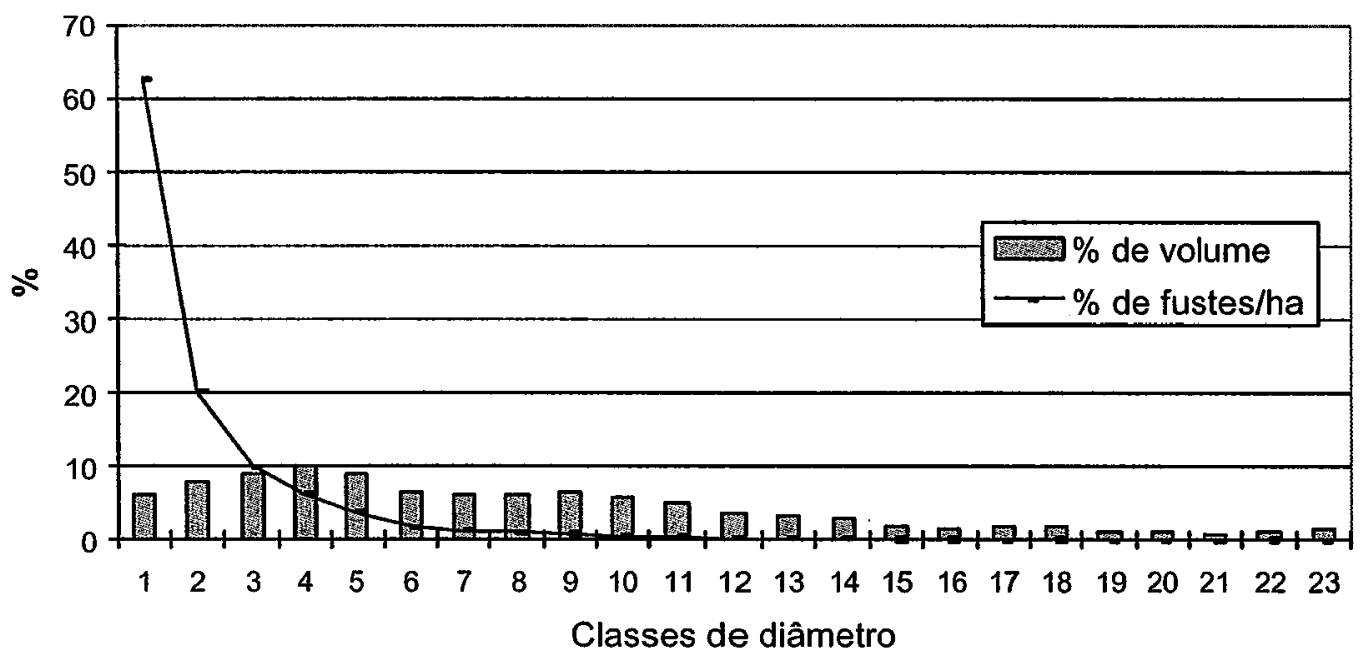

Figura 26 - Distribuição do volume e da quantidade de fustes amostrados pelas classes de diâmetro amostradas pelo método de parcelas, na floresta da Estação Ecológica dos Caetetus Gália, SP. $1=$ classe de 5,0 a $10,0 \mathrm{~cm}, 2=$ classe de 10,1 a $15 \mathrm{~cm}, 3=$ classe de $15,1 \mathrm{~cm}$ a $20 \mathrm{~cm}$, ...... $22=$ classe de 110,1 a $115,0 \mathrm{~cm} \mathrm{e} 7=$ classes maiores que $115,1 \mathrm{~cm}$ 
Tabela 5. Volume das classes de madeira estudadas e suas percentagens de contribuição em relação ao estoque total, numa floresta estacional semidecidual da Estação Ecológica dos Caetetus - Gália, SP. Método de parcelas

\begin{tabular}{ccc|c|c|c|c}
\cline { 2 - 7 } & Classe I & Classe II & Classe III & Lenha & Total $\left(\mathrm{m}^{3} \mathrm{ha}^{-1}\right)$ & $\%$ \\
\hline Estoque de Crescimento & 3,42 & 2,24 & 1,54 & - & 7,20 & 4,22 \\
Estoque de Produção & 28,85 & 14,83 & 27,14 & - & 70,82 & 41,52 \\
Lenha & - & - & - & - & 92,54 & 54,26 \\
Total $\left(\mathrm{m}^{3} \mathrm{ha}^{-1}\right)$ & 32,27 & 17,07 & 28,68 & 92,54 & 170,56 & - \\
$\%$ & 18,92 & 10,01 & 16,81 & 54,26 & - & 100 \\
\hline
\end{tabular}

Nas tabelas 6, 7 e 8, são apresentados os volumes e os percentuais de participação do totais de volume estimados para as espécies das classes de valor comercial estudadas, considerando-se as duas metodologias de levantamento aplicadas. Observa-se, que os percentuais estimados para as classes raramente apresentam diferenças maiores do que a $2 \%$, entre os métodos. Para as madeiras de classe I (Tabela 6), o volume estimado foi de $18,92 \%$ nas parcelas e $20,74 \%$ no método dos quadrantes. Esta classe foi a única que obteve maior estimativa pelos quadrantes. A espécie $C$. tomentosum, obteve maior estimativa, através do método de parcelas. A peroba participou com $18,22 \%$ do volume estimado para as marcelas e $18,85 \%$ dos quadrantes, apresentando-se com valores próximos aos encontrados por Campos e Heinsdjik (1970), no Morro do Diabo.

As madeiras de classe II (Tabela 7) foram estimadas em 10,1\% nas parcelas e $8,86 \%$ nos quadrantes, e para as madeiras de classe III (Tabela 8 ), estimou-se o volume em $16,81 \%$ nas parcelas e $16,07 \%$ nos quadrantes. 
Tabela 6. Volume e percentual estimado para as madeiras de classe I, amostradas na floresta estacional semidecidual da Estação Ecológica dos Caetetus - Gália, SP

Madeiras de Classe I

\begin{tabular}{l|l|c|c|c|c}
\hline \multirow{2}{*}{ Nome Científico } & \multirow{2}{*}{ Nome Popular } & \multicolumn{2}{|c|}{ Parcelas } & \multicolumn{2}{c}{ Quadrantes } \\
\cline { 3 - 7 } & & $\mathrm{m}^{3} \mathrm{~h}^{-1}$ & $\begin{array}{r}(\%) \mathrm{do} \\
\text { Total }\end{array}$ & $\mathrm{m}^{3} \mathrm{~h}^{-1}$ & $\begin{array}{r}(\%) \mathrm{do} \\
\text { Total }\end{array}$ \\
\hline Aspidosperma polyneuron & Peroba-rosa & 18,22 & 10,68 & 18,85 & 11,11 \\
Cariniana estrelensis & $\begin{array}{l}\text { Jaquitibá- } \\
\text { branco }\end{array}$ & 0,35 & 0,20 & 1,72 & 1,01 \\
Cedrela fissilis & Cedro-rosa & 1,24 & 0,73 & 1,63 & 0,96 \\
Centrolobium tomentosum & Araribá & 8,37 & 4,91 & 7,33 & 4,32 \\
Myroxylon peruiferum & Cabreúva- & 0,39 & 0,23 & - & - \\
Patagonula americana & vermelha & & & & \\
TOTAL & guaiuvira & 3,68 & 2,16 & 5,66 & 3,34 \\
\hline
\end{tabular}

Tabela 7. Volume e percentual estimado para as madeiras de classe II, amostradas na floresta estacional semidecidual da Estação Ecológica dos Caetetus - Gália, SP

\section{Madeiras de Classe II}

\begin{tabular}{l|l|l|c|c|c}
\hline \multirow{2}{*}{ Nome Científico } & \multirow{2}{*}{ Nome Popular } & \multicolumn{3}{|c|}{ Parcelas } & \multicolumn{2}{|c}{ Quadrantes } \\
\cline { 3 - 7 } & & $\mathrm{m}^{3} \mathrm{~h}^{-1}$ & $\begin{array}{r}(\%) \text { do } \\
\text { Total }\end{array}$ & $\mathrm{m}^{3} \mathrm{~h}^{-1}$ & $\begin{array}{c}(\%) \mathrm{do} \\
\text { Total }\end{array}$ \\
\hline Astronium graveolens & Guarita & 1,74 & 1,02 & 2,57 & 1,51 \\
Balfourodendron riedelianum & Pau-marfim & 7,07 & 4,14 & 5,08 & 2,99 \\
Cabralea canjerana & Canjarana & 1,82 & 1,07 & 0,96 & 0,56 \\
Holocalyx balansae & Alecrim & 2,64 & 1,54 & 3,71 & 2,19
\end{tabular}


Tabela 7. Volume e percentual estimado para as madeiras de classe II, amostradas na floresta estacional semidecidual da Estação Ecológica dos Caetetus - Gália, SP.

\section{Madeiras de Classe II}

\begin{tabular}{llllll}
\hline Luehea divaricata & Açoita-cavalo & 0,23 & 0,13 & 1,07 & 0,63 \\
Maclura tinctoria & Taúva & 0,09 & 0,05 & - & - \\
Parapiptadenia rigida & Angico-do- & 1,68 & 0,98 & 0,44 & 0,26 \\
& $\begin{array}{l}\text { mato } \\
\text { canafistula }\end{array}$ & 1,50 & 0,88 & 0,89 & 0,52 \\
Peltophorum dubium & Saguaragi- & 0,30 & 0,17 & 0,31 & 0,18 \\
Rhamnidium elaeocarpum & amarelo & 17,07 & 10,01 & 15,03 & 8,84 \\
TOTAL & & & & &
\end{tabular}

Tabela 8. Volume e percentual estimado para as madeiras de classe III, amostradas na floresta estacional semidecidual da Estação Ecológica dos Caetetus - Gália, SP

\begin{tabular}{|c|c|c|c|c|c|}
\hline \multicolumn{6}{|c|}{ Madeiras de Classe III } \\
\hline \multirow[b]{2}{*}{ Nome Científico } & \multirow[b]{2}{*}{ Nome Popular } & \multicolumn{2}{|c|}{ Parcelas } & \multicolumn{2}{|c|}{ Quadrantes } \\
\hline & & $m^{3} h^{-1}$ & \begin{tabular}{|c}
$(\%)$ do \\
Total
\end{tabular} & $m^{3} h^{-1}$ & \begin{tabular}{|c|}
$(\%)$ do \\
Total
\end{tabular} \\
\hline Albizia haslerii & Farinha-seca & 0,13 & 0,08 & - & - \\
\hline Alchornea glandulosa & Caixeta & 0,43 & 0,25 & 1,13 & 0,67 \\
\hline Casearia gossypiosperma & Espeteiro & 0,20 & 0,12 & 0,17 & 0,10 \\
\hline Chorisia speciosa & Paineira & 3,81 & 2,23 & 5,80 & 3,42 \\
\hline Cróton floribundus & Capixingui & 3,38 & 1,98 & 2,83 & 1,67 \\
\hline Gallesia integrifolia & Pau-d'alho & 14,98 & 8,78 & 11,86 & 6,99 \\
\hline Jacaranda micrantha & Caroba & 0,14 & 0,08 & 0,17 & 0,10 \\
\hline Lonchocarpus cultratus & Imbira-de-sapo & 2,5 & 1,46 & 3,80 & 2,24 \\
\hline Machaerium nictitans & Bico-de-pato & 0,36 & 0,21 & 0,02 & 0,01 \\
\hline Machaerium stipitatum & Sapuvinha & 2,61 & 1,53 & 1,22 & 0,72 \\
\hline
\end{tabular}


Tabela 8. Volume e percentual estimado para as madeiras de classe III, amostradas na floresta estacional semidecidual da Estação Ecológica dos Caetetus - Gália, SP.

\section{Madeiras de Classe III}

Zanthoxylum fagara

Mamica-de-

porca

$$
0,14 \quad 0,08 \quad 0,26 \quad 0,15
$$

TOTAL

$28,68 \quad 16,81 \quad 27,26$

A estimativa de valor total obtida pelo método de quadrantes não apresentou diferença estatisticamente significativa, quando comparada com o valor obtido pelo método de parcelas. As estimativas de volume relativas às espécies de valor comercial apresentaram diferenças sempre menores do que $3 \%$.

Esses resultados indicaram, que considerando o modelo utilizado, o método de quadrantes configurou-se como uma boa ferramenta para a estimativa de volume, considerando-se ainda, maior facilidade e menor tempo de implantação (menor custo), e a eficiência na amostragem florística.

Com relação aos resultados finais, dois aspectos necessitam ser ressaltados. $\mathrm{O}$ primeiro está relacionado a uma possível sub estimativa de volume do estoque da vegetação estudada, quando foram ajustados modelos criados para avaliar uma floresta estacional semidecidual montana em Lavras (MG), que certamente possui árvores de menor porte do que na área da Estação Ecológica dos Caetetus. O segundo aspecto, ao contrário do primeiro, está relacionado à possibilidade de super estimativa, a partir do momento em que se utilizou a estimativa de volume total da área possuidora das maiores árvores da Unidade, para estimar o valor total do estoque da gleba.

Vieira (1989), estudando a floresta estacional semidecidual no Parque Estadual da Vassununga, estimou o volume total da floresta em $194,05 \mathrm{~m}^{3} \mathrm{ha}^{-1}$. Entretanto, essa estimativa foi fortemente influenciada pela área basal dos grandes indivíduos de Cariniana legalis (jequitiba-rosa), que contribuíram com $35,04 \%$ do volume total. Podese observar que os valores obtidos no presente estudo, alcançaram $87,8 \%$ do volume da Vassununga. 


\subsection{Do Laudo pericial de desapropriação da Estação Ecológica dos Caetetus.}

\subsubsection{Introdução}

As unidades de conservação, principalmente aquelas sob a administração pública, ocupam um espaço muito importante como áreas de proteção, uma vez que se impõem como depósitos vivos da biodiversidade e deverão ser as testemunhas desta biodiversidade para futuras gerações.

Para a efetivação dessas unidades de conservação, que representam a consolidação de importante incremento na qualidade de vida da população, o poder público, dentro de suas atribuições, compra áreas que contenham patrimônio ambiental significativo e, após o trâmite do processo de desapropriação, paga o preço da propriedade.

Como é de praxe nos processo de desapropriação direta, cabe ao poder público fazer a oferta ao proprietário. É também de praxe que este último, não aceitando a oferta, ofereça contestação, expondo ao juiz os motivos pela sua discordância, fazendo com que o magistrado indique o seu assistente, na pessoa de um perito judicial, que poderá ser acompanhado pelos assistentes técnicos instituídos pelas partes. O perito judicial deverá realizar perícias na propriedade e, baseado em procedimentos técnicos, elaborar um relatório técnico (laudo), que terá como principal objetivo subsidiar o juiz na sua decisão final, quanto à estipulação do valor final a ser pago pela propriedade.

No entanto, ao estudarem alguns laudos que instruíram processos de desapropriação de áreas pertencentes ao Parque Estadual da Serra do Mar, Schwenck Jr. e Azevedo (1998) observaram que em alguns casos, foi atribuído valor "exorbitante" para a propriedade. Concluíram que, entre os erros cometidos pelos peritos, está a classificação botânica incompleta das espécies ocorrentes na área, e o embasamento técnico nos procedimentos de levantamento florestal. Esses problemas, além de outros, contribuíram para que, em alguns casos, a contribuição do valor da cobertura vegetal superasse o valor da "terra nua" em mais de 30 vezes. 
Assim, será apresentada neste item uma comparação entre os dados apontados no relatório anexado ao laudo pericial de desapropriação da Estação Ecológica dos Caetetus (EEC), com os resultados do levantamento realizado neste estudo e considerações sobre a legislação florestal. Espera-se fornecer subsídios ou mesmo oferecer um rol de procedimentos, que venham subsidiar a elaboração de futuros laudos de desapropriação, tanto em áreas do estado de São Paulo, como em outras regiões do Brasil.

É importante ressaltar que, os valores apresentados pelo perito no seu relatório em 1977, serão atualizados para os valores de hoje, pela tabela prática para cálculo de atualização monetária dos débitos judiciais (editada em 10/07/2003) do Tribunal de Justiça do Estado de São Paulo e posteriormente, confrontados com os preços praticados atualmente, na região da Estação Ecológica dos Caetetus.

\subsubsection{Histórico}

Para se comparar os resultados referentes à qualidade e quantidade da madeira obtidos pelos métodos de amostragem analisados neste estudo, com aqueles apresentados no laudo de desapropriação da área da Estação Ecológica dos Caetetus, foi necessário a leitura dos 6 volumes que compõem o processo 559/77 do Poder Judiciário - Comarca de Garça. A área da EEC foi declarada de utilidade pública pelo Decreto ${ }^{\circ}$ 8.346 de 9 de agosto de 1976, publicado no Diário Oficial do dia 10 de agosto de 1976.

Também fazem parte do mesmo processo: o relatório do perito da Procuradoria Geral do Estado - Procuradoria do Patrimônio Imobiliário, que será denominado de Laudo Inicial; o relatório do perito judicial (Laudo Pericial) e os laudos divergentes dos assistentes técnicos das partes. Nos itens seguintes, serão apresentadas algumas considerações sobre aqueles relatórios, ressaltando os aspectos que estão mais diretamente relacionados com a quantificação e a qualificação da vegetação. Cabe aqui ressaltar, que existem nos documentos, muitas outras informações, relacionadas principalmente à pesquisa de preços da terra e componentes econômicos, que não serão aqui discutidas. 


\subsubsection{Laudo técnico inicial}

O primeiro documento oficial de valoração a compor o processo (datado em 14 de fevereiro de 1977), foi um laudo técnico elaborado pelo engenheiro Chefe do Escritório Regional de Bauru, da Procuradoria do Patrimônio Imobiliário, órgão da Procuradoria Geral do Estado de São Paulo. Neste documento, o autor compõe o valor da propriedade, colocando os seus argumentos em 4 tópicos ou itens, sendo: 1. Preliminares, onde apresenta as informações de localização e vias de acesso; 2. Memorial descritivo; 3. Avaliação, em que transcreve as pesquisas realizadas para levantamento de preços de imóveis considerados de condições semelhantes à gleba da atual EECe compondo o valor total desta, através da soma dos valores da terra nua e da mata; 4. Encerramento.

$\mathrm{O}$ autor faz constar em seu relatório que "... a mata existente dentro da área hora exproprianda é totalmente virgem e segundo madeireiros da região, numa mata deste tipo pode-se, facilmente, se obter $800 \mathrm{~m}^{3}$ por alqueire de madeira". Estipula o valor total da propriedade em Cr\$35.457.633,00 (trinta e cinco milhões, quatrocentos e cinqüenta e sete mil, seiscentos e trinta e três cruzeiros). Esse valor corrigido pela tabela de atualização monetária dos débitos judiciais do Tribunal de Justiça de São Paulo corresponde a $\mathrm{R} \$ 4.420 .218,76$ (quatro milhões, quatrocentos e vinte mil, duzentos $\mathrm{e}$ dezoito Reais e setenta e seis centavos).

\subsubsection{Laudo Judicial}

Em 08 de dezembro de 1977, após as vistorias realizadas no local e diligências necessárias, o perito judicial apresentou o seu laudo que, dentre outras, constam as seguintes informações: 1. Considerações gerais, onde faz um breve relato sobre os fatos que originaram o processo, salientando o valor da oferta inicial em Cr\$35.457.633,00 (R\$ 4.420.218,76), mais a participação dos assistentes técnicos das partes. Relata um pouco da historia da colonização da região, ressalta a qualidade da terra com cafeicultura e descreve as características da Fazenda Paraíso, de onde foi desapropriada a área; 2. Da 
gleba desapropriada, onde descreve e classifica a gleba segundo a topografia, a capacidade de uso e as características de acesso. $\mathrm{O}$ autor cita que durante as incursões que realizou na mata pode notar que "... a mata da Fazenda Paraiso é exuberante e notável pelo enorme concentração de madeiras de Lei, como perobas, cedro, cabreúvas, ipês, guarantãs, pau-brasil, etc". Faz comentários sobre a fauna, citando a amabilidade dos catetos, sugerindo ao Estado que “... para preservar ao máximo esses animais deverse-iam construir alambrados em volta da mata"; 3.Avaliação. Neste tópico o perito judicial adota o critério de valoração da terra nua, citando novamente a qualidade da terra e classificando-a pelos critérios de Norton. Classificou as espécies em: madeiras de Lei, madeiras brancas e madeiras para lenha. Apresentou uma relação das espécies indicando somente nomes populares que comporiam os três tipos de madeira citados acima, indicando alguns usos comuns para cada uma delas. Comentou a estimativa de volume de madeira obtida no laudo inicial, fazendo algumas considerações e reduzindo para $750 \mathrm{~m}^{3}$ por alqueire, o provável volume que seria retirado da foresta. Baseado em depoimentos de madeireiros da região, o perito estimou que a percentagem provável de estoque de madeira de Lei seria de $22,5 \%$, de madeira branca $22,5 \%$ e $55 \%$ de lenha.

\subsubsection{Laudos Divergentes}

\subsection{Dos proprietários}

O assistente técnico representante dos proprietários, como era de se esperar, fez uma série de considerações em seu relatório, datado em 20 de dezembro de 1977, questionando alguns procedimentos adotados na pesquisa de preços para a terra nua, concordou com a qualificação da madeira, porém, insistiu que a floresta poderia produzir $800 \mathrm{~m}^{3}$ por alqueire, conforme a afirmativa do laudo inicial da Procuradoria Geral do Estado. 


\subsection{Da Fazenda do Estado de São Paulo}

O assistente técnico da Fazenda do Estado apresentou em seu laudo divergente datado em 30 de janeiro de 1978, uma boa descrição das características edáficas da região, bem como uma rica listagem de espécies encontradas na área, com o respectivo nome científico e popular. Questionou os critérios da classificação de Norton e afirmou que a produtividade da floresta deve ser de $700 \mathrm{~m}^{3}$ por alqueire. Argumentou que a percentagem de madeira de Lei não deve ultrapassar $15 \%$, a madeira branca $20 \%$ e $65 \%$ de lenha.

\subsubsection{Decisão do Juiz}

Em 20 de fevereiro de 1978, o então MM. Juiz de Direito da Comarca de Garça emitiu o seu parecer: ‘它 o relatório. Decido. Acolho, em parte o laudo ofertado pelo culto e digno perito judicial. Com base em sua larga experiência, fundou-se em critérios comparativos, estribando-se em dados não só empíricos, mas também técnicos, para alcançar o justo valor da indenização".

Em outra parte do seu relatório, o MM Juiz escreve: “..... quanto ao valor da mata, trata-se de estimativa, obtida pelo estudo aerofotogramétrico, pequenas incursões no interior da mata e comparação de depoimentos de pessoas ligadas ao mercado madeireiro. Os percentuais alcançados pelo Vistor Oficial para a classificação da mata em madeira de lei, madeira branca e lenha não merecem crítica, porque apurado através de acurado trabalho de pesquisa, em fontes fidedignas".

Acompanhando as considerações feitas pelo perito judicial, o magistrado estipulou o valor a ser pago pela propriedade em Cr\$169.848.141,00 como resultado da composição entre valor da terra nua $\mathrm{Cr} \$ 58.393 .747,00$ mais o valor da cobertura vegetal $\mathrm{Cr} \$ 103.366 .388,00$ e a preservação da fauna $\mathrm{Cr} \$ 8.088 .006,00$. O valor total corresponde a atualmente a $\mathrm{R} \$ 21.173 .605,67$. 


\subsubsection{Considerações gerais a cerca do processo}

A respeito do relatório final do perito judicial e da decisão do MM. Juiz há que se comentar alguns aspectos, que serão comparados com os dados obtidos nos tópicos anteriores.

\subsubsection{Identificação das espécies}

O perito judicial afirma ter feito incursões pela mata, porém, pelo que se pode observar na documentação apresentada, não fez nenhum tipo de amostragem na área. Mesmo assim, o MM juiz, em sua decisão, reconhece o trabalho do perito comentado que o mesmo não merece críticas “.... porque foi apurado através de acurado trabalho de pesquisa, em fontes fidedignas".

É apresentada uma pequena lista de espécies que possivelmente seriam encontradas na gleba, sendo referenciadas apenas por nomes populares regionais. $\mathrm{O}$ perito considerou as espécies na seguinte classificação: madeiras de Lei (classe I + classe II), madeiras brancas (classe III) e madeiras para lenha.

Entre as madeiras de classe I, citou araribá, cabriúva, cedro, guaiúvira, jequitibá e peroba. É importante ressaltar que o perito usou somente nomes populares para as espécies.

Entre as madeiras de classe II relacionou: açoita-cavalo, alecrim, angico-domato, canela, canjarana, cega-olho, cinzeiro-do-mato, coração-de-negro, copaíba, dedal, faveiro,garapa, guarita, guarucaia, guatambu, ibirá, ipê, jatobá, maçaranduba, marinheiro, pindaíba, piúna, saguaragi, sibrasil e taiuva.

Como madeiras brancas ou de classe III, o perito relacionou: bico-de-pato, caixeta, capixingui, caroba, farinha-seca, imbira-de-sapo, jacarandá-mimoso, mamicade-porca, pau-d'alho, pau-espeto, paineira e sapuva.

Os levantamentos realizados no presente estudo amostraram 140 espécies pelo método das parcelas e 95 pelos quadrantes e a maioria dessas espécies foram identificadas pelos respectivos nomes científicos. Mesmo assim, algumas das espécies 
citadas no laudo judicial não foram encontradas. Outras, como por exemplo, cinzeirodo-mato, piúna e cega-olho, não se consegui identificar com os mateiros da região. Além disso, com o nome popular de "canela" existem várias plantas, praticamente todas as espécies da família Lauraceae, não sendo possível identificar a espécie exata a qual o perito judicial se referiu. Chama a atenção na listagem geral de espécies citadas pelo perito, a possível presença de jacarandá-mimoso e pau-brasil. Sabe-se que a primeira não é nativa no Basil, e a segunda, não possui registros de ocorrência no Estado de São Paulo.

A dificuldade de identificação de espécies pelo nome popular entre aquelas relacionadas no laudo judicial e as obtidas no presente estudo, evidencia a necessidade da utilização da identificação botânica correta das espécies com seus respectivos nomes científicos, pois os nomes populares mudam de uma região para outra. Também, por conta da identificação incorreta das espécies, a valoração do estoque pode ficar prejudicada.

Saliente-se também, que apesar de considerar a mata a ser desapropriada como "exuberante", o perito não apresentou informações relativas à estrutura da floresta. Não existem informações consistentes sobre grau de maturidade da vegetação analisada.

\subsubsection{Volume de madeira}

O perito judicial utilizou-se das informações referentes à estimativa do estoque de madeira da floresta fornecidas pelo engenheiro Chefe do Escritório Regional de Bauru, da Procuradoria do Patrimônio Imobiliário, em seu laudo inicial, onde através de depoimentos de madeireiros da região, obteve a estimativa de volume total de $800 \mathrm{~m}^{3}$ por alqueire, ou $330,58 \mathrm{~m}^{3}$ por hectare. Após avaliar esses depoimentos, o perito judicial preferiu aceitar o valor médio entre os citados, obtendo então, a estimativa de $750 \mathrm{~m}^{3}$ por alqueire ou $309,92 \mathrm{~m}^{3} \mathrm{ha}^{-1}$.

A Figura 27 apresenta a comparação das estimativas totais de volume obtidas pelo laudo de desapropriação ambiental da Estação Ecológica dos Caetetus e os inventários realizados pelos métodos de parcelas e quadrantes. Conforme pode ser 
observado, o volume estimado pelos métodos aplicados, de $170,56 \mathrm{~m}^{3} \mathrm{ha}^{-1}$ para parcelas e $169,66 \mathrm{~m}^{3} \mathrm{ha}^{-1}$, pelo método dos quadrantes, são bem inferiores quando comparados com a estimativa de volume total apresentada no laudo judicial, onde os valores estimados pelos inventários representam cerca de 56\% daquele indicado pelo perito.Schwenck Jr e Azevedo (1998) relatam vários casos relacionados ao Parque Estadual da Serra do Mar, em que também foram notadas grandes diferenças entre os valores reais de volume da floresta, com aqueles apresentados nos laudos judiciais.

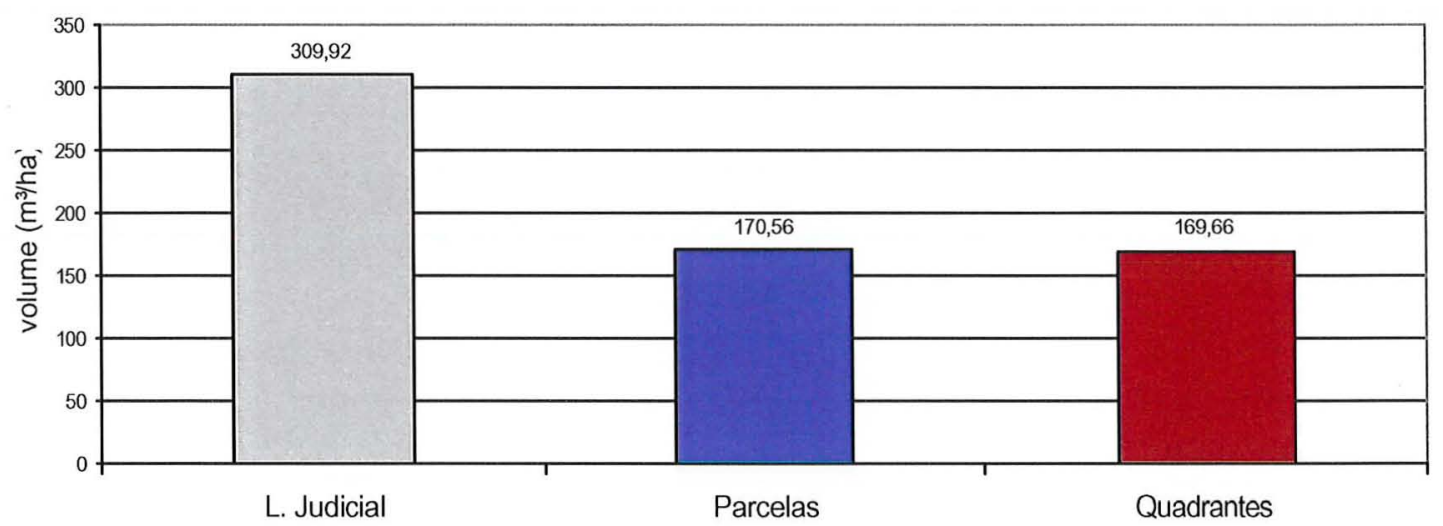

Figura 27 - Estimativas de volume total da floresta pelo laudo pericial de desapropriação (L. judicial) e os inventários realizados pelo método de parcelas e de quadrantes na floresta da Estação Ecológica dos Caetetus - Gália, SP

Também por inferência dos dados apresentados no laudo inicial, o perito judicial estimou em 22,5\% $\left(69,73 \mathrm{~m}^{3} \mathrm{ha}^{-1}\right)$ a percentagem de madeiras de Lei, $22,5 \%\left(69,73 \mathrm{~m}^{3} \mathrm{ha}^{-}\right.$ $\left.{ }^{1}\right)$ as madeiras brancas e $55 \%\left(170,45 \mathrm{~m}^{3} \mathrm{ha}^{-1}\right)$ o percentual de lenha existente na floresta.

A Figura 28 apresenta a comparação entre os dados indicados no laudo judicial de desapropriação e o resultados obtidos nos levantamentos realizados neste estudo, relativos à partic ipação das classes de valor comercial de madeira, na estimativa de volume total da floresta. Nota-se que os valores indicados pelo perito, de maneira geral, superestimam todas as classes, porém pode-se constatar que essa super estimativa é ainda maior para as madeiras de classe III, pois observa-se que dos levantamentos para essa classe, são menores do que para as madeiras de classe I + II. 


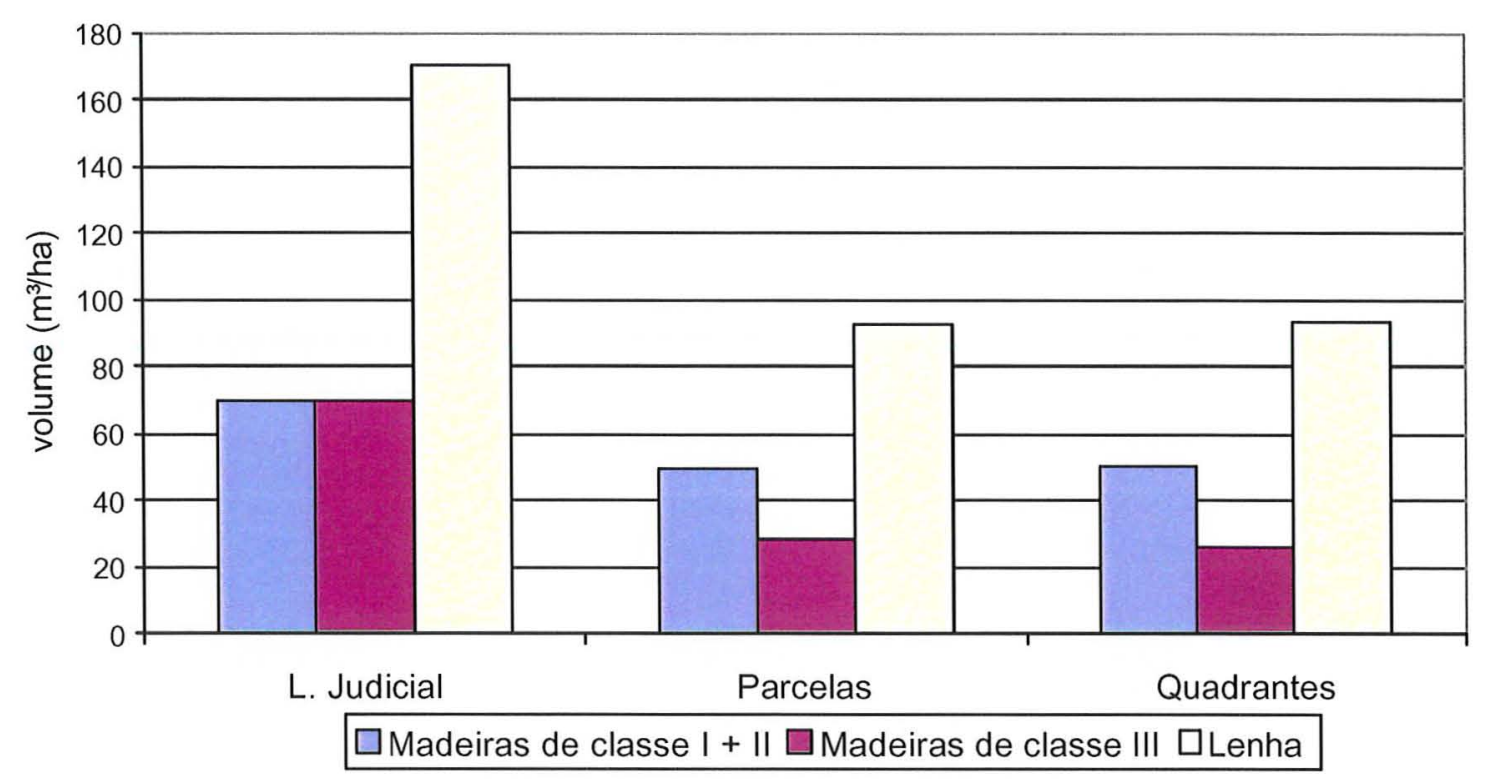

Figura 28 - Estimativas de volume por classes de valor comercial, obtido pelo laudo pericial de desapropriação (L. judicial) e os inventários realizados pelo método de parcelas e de quadrantes na floresta da Estação Ecológica dos Caetetus - Gália, SP

Após comparar o valor de notas fiscais de compra de toras adquiridas por serrarias da região de Marilia, o perito judicial abateu do total o preço do corte e do frete, obtendo o valor de Cr\$450,00 para o metro cúbico de toras de madeiras de Lei (classe I + II), Cr $\$ 191,00 / \mathrm{m}^{3}$ para as madeiras brancas (classe III) e $\mathrm{Cr} \$ 15,00 / \mathrm{m}^{3}$ para a lenha. Esses valores corrigidos para valores de hoje representariam $\mathrm{R} \$ 56,10 / \mathrm{m}^{3}$ para as madeiras de classe I e II, $\mathrm{R} \$ 23,81 / \mathrm{m}^{3}$ para as madeiras de classe III e $\mathrm{R} \$ 1,87 / \mathrm{m}^{3}$ para a lenha.

Segundo Humphreys ${ }^{3}$, estes mesmos valores vem sendo praticados atualmente (07/2003) para as madeiras da mata atlântica, exceto para o valor da lenha, que tem sido comercializada ao preço de $\mathrm{R} \$ 4,00 / \mathrm{m}^{3}$. Serão estes, portanto, os valores utilizados neste trabalho.

\footnotetext{
${ }^{3}$ Dr. Rubens Dias Rumphreys - Pesquisador do IPT - (Comunicação pessoal)
} 
O perito judicial calculou o "valor total do hectare de mata" tendo em conta a sua capacidade de produzir renda, mediante a exploração das madeiras de Lei e branca para serraria, e da produção de lenha. Como lenha estariam incluídas as espécies que não seriam utilizadas em serrarias, além daquelas que não apresentam dimensões comerciais, ou seja, diâmetro inferior a $20 \mathrm{~cm}$, obtendo o valor total da mata por hectare, da seguinte maneira:

$\begin{array}{ccccccc} & \% & \mathrm{M}^{3} & & \mathrm{Cr} \$ / \mathrm{m}^{3} & & \mathrm{Cr} \$ \\ \text { Madeiras de Lei } & 22,5 & 69,73 & \mathrm{X} & 450,00 & = & 31,378,50 \\ \text { Madeiras Brancas } & 22,5 & 69,73 & \mathrm{X} & 191,00 & = & 13,318,43 \\ \text { Lenha } & 55,0 & 170,45 & \mathrm{X} & 15,00 & = & 2,556.75 \\ \text { TOTAL } & & & & & & \mathbf{4 7 . 2 5 3 , 6 8}\end{array}$

$(\mathbf{R} \$ 5.890,74)$

Calculando-se o valor total da mata por hectare, aplicando-se o valor de mercado atual, através do volume total estimado para as classes, obtidos através do levantamento deste estudo (Tabela 5), obteve-se:

$\begin{array}{cccccccc} & \% & \mathrm{M}^{3} & & \mathrm{R} \$ \mathrm{~m}^{3} & & \mathrm{R} \$ / \mathrm{ha} \\ \text { Madeiras de Lei } & 25,61 & 49,34 & \mathrm{X} & 56,10 & = & 2.767,97 \\ \text { Madeiras Brancas } & 15,91 & 28,68 & \mathrm{X} & 23,81 & = & 682,87 \\ \text { Lenha } & 58,48 & 92,57 & \mathrm{X} & 4,00 & = & 370,28 \\ \text { TOTAL } & & & & & & \mathbf{3 . 8 2 1 , 1 2}\end{array}$

Entretanto, do volume estimado pelos levantamentos neste trabalho, há que se descontar o volume dos fustes com DAPs menores do que $20 \mathrm{~cm}$, pois estes fustes se mostram inviáveis para processamento em serrarias. É possível que os mesmos possam ser utilizados com outras finalidades que não a lenha, como por exemplo, em estacas de cerca ou esteios de construções rurais, entretanto, como o perito não considerou esta 
perspectiva, e para facilitar a comparação com os dados fornecidos pelo laudo judicial, o volume obtido de $7,20 \mathrm{~m}^{3} \mathrm{ha}^{-1}$ referente aos fustes do estoque de crescimento (DAPs menores de $20 \mathrm{~cm}$ ) das espécies comerciais foi somado ao volume estimado de lenha de 92,54m $\mathrm{m}^{3} \mathrm{ha}^{-1}$ (Tabela 5), resultando em $99,74 \mathrm{~m}^{3} \mathrm{ha}^{-1}$.

Assim, calculando-se o valor total da mata por hectare, aplicando-se o valor de mercado atual, através do estoque de produção (DAP $>20 \mathrm{~cm}$ ), conforme os dados da Tabela 5, obteve-se:

$\begin{array}{cccccccc} & \% & \mathrm{M}^{3} & & \mathrm{R} \$ \mathrm{~m}^{3} & & \mathrm{R} \$ \mathrm{ha} \\ \text { Madeiras de Lei } & 25,61 & 43,68 & \mathrm{X} & 56,10 & = & 2.450,44 \\ \text { Madeiras Brancas } & 15,91 & 27,14 & \mathrm{X} & 23,81 & = & 646,20 \\ \text { Lenha } & 58,48 & 99,74 & \mathrm{X} & 4,00 & = & 398,96 \\ \text { TOTAL } & & & & & & \mathbf{3 . 4 9 5 , 6 0}\end{array}$

Observa-se, portanto, que a análise da distribuição diamétrica das árvores das espécies comerciais (etimativa do volume de crescimento) resultou em um valor total por hectare, cerca de 4,5\% (R\$ 325,52) menor, quando comparado ao cálculo que utiliza o valor total das espécies.

Considerando-se então o valor da madeira obtido através da estimativa do estoque de produção ( $R \$ 3.495,60 \mathrm{ha}^{-1}$ ), obteve-se uma redução de cerca de $40 \%$ no valor total de mata por hectare, quando comparado com o valor proposto no laudo judicial (R\$ 5.890,74ha-1 $)$.

\subsubsection{3 Áreas de preservação permanente}

A valoração da cobertura vegetal da gleba, a qual o perito judicial denominou "Valor Total da Mata" no item 3.4 do seu laudo, foi composta exclusivamente, pelo produto entre o "valor total das madeiras por hectare" (item 3.4.1) e a área da gleba (2.176ha). O assistente do juiz desconsiderou por completo, as restrições legais que 
impedem categoricamente a derrubada da floresta, fazendo com que parte da madeira, considerada de preservação permanente, tivesse o seu preço incorporado ao valor da gleba.

\subsection{Declividade do solo}

Com relação à declividade do solo, o perito considerou a classificação das terras segundo a Conversão de Norton, afirmando tratar-se do critério mais recomendado. Esta classificação, segundo o perito, baseia-se em critérios suficientemente objetivos que enquadram todos os tipos de solo economicamente exploráveis. Assim, as terras da gleba em questão receberam a seguinte classificação: $60 \%$ terras de primeira (Classes I e II), $30 \%$ de terras de segunda (Classe III) e 10\% outras terras (Classes V a VIII).

A classificação proposta pelo pesquisador Norte-americano E. A. Norton é adotada em nosso meio através da NB-613, elaborada e aprovada pela Associação Brasileira de Normas Técnica - ABNT (Schwenck Jr. e Mello, 1998).

Os solos de classe I, segundo Schwenck Jr. e Mello (1998), compreendem os de boa fertilidade e drenagem, em condições de relevo plano, estão entre as melhores e mais caras terras do Estado de São Paulo, podendo-se admitir que estão entre as mais caras de todo o País. Para classes de capacidade de uso de maiores restrições os valores de mercado são menores, sendo que o menor valor é imputado para as terras de classe VIII, extremamente declivosas, consideradas refúgio da vida silvestre em função da inaptidão para as atividades agrosilvopastoris. Apesar de abordar as classes de capacidade de uso do solo, o perito desconsiderou as restrições legais que impedem categoricamente o corte total da floresta, fazendo com que o volume de madeira dessa área de declive acentuado, também fosse incorporado ao valor da propriedade.

Segundo Tabanez et al.(no prelo), na área da Estação Ecológica dos Caetetus predominam as baixas declividades, inferiores a $6 \%$, porém existe uma escarpa íngreme bem demarcada, com desníveis em torno dos 100 metros e vertentes retilíneas, com declividades acentuadas, acima de 12\%, ocupando uma extensão de cerca de 40 hectares 
da Unidade de Conservação. Caracterizou o solo desta área como sendo frágil e pouco profundo, que propicia a circulação de águas superficiais intensa, acentuando a erosão. Dessa maneira, pode-se aceitar para esta área de escarpa, as disposições da Lei $n^{\circ} 4.771$ de 15 de setembro de 1965 (Código Florestal), conforme o disposto no Art. $2^{\circ}$, alínea "e", onde, é considerada área de preservação permanente, pelo só efeito desta Lei, as florestas e demais formas de vegetação natural situadas na encostas ou partes destas, com declividade superior a $45^{\circ}$, equivalente a $100 \%$ na linha de maior declive.

$\mathrm{O}$ artigo $10^{\circ}$ da mesma Lei impõe que: “..não é permitida a derrubada de florestas situadas em áreas de inclinação entre 25 e 45 graus, só sendo nelas toleradas a extração de toras, quando em regime de utilização racional que vise a rendimentos permanentes.

$\mathrm{O}$ artigo $3^{\circ}$ considera também de grande importância, outras áreas que devam ser mantidas intactas, com a preocupação de atenuar a erosão das terras (alínea "a") e assegurar as condições de bem-estar público (alínea " $h$ ").

Isso implica dizer, que mesmo que a área da escarpa não seja totalmente protegida por lei, pois não apresenta declividade de $25^{\circ}$ a $45^{\circ}$ em toda a sua extensão, a retirada da floresta da encosta fatalmente acarretaria no assoreamento dos cursos d'água à jusante, prejudicando as condições de bem-estar público. Assim, caberia ao perito alertar o MM. Juiz, da importância da manutenção da floresta naquela área, recomendando e justificando, portanto, que a mesma não fosse computada para a composição da valoração final da propriedade, uma vez que não poder ser cortada,.

\subsection{Nascentes e cursos d'água}

A mesma Lei citada no item anterior, no seu Artigo $2^{\circ}$, considera também de preservação permanente, as florestas e demais formas de vegetação natural ao longo dos rios ou de qualquer outro curso d'água (alínea "a"), estabelecendo as larguras mínimas que a vegetação deverá ser mantida, de acordo com a largura do curso d'água. Quanto à nascente, o mesmo Artigo, na alínea "c", estabelece que a vegetação deverá ser preservada num raio mínimo de 50 metros no seu entorno, qualquer que seja a sua situação topográfica. 
Segundo Tabanez et al.(no prelo), existe cerca de 37.501 metros de cursos d'água, na área da Estação Ecológica dos Caetetus, compreendendo córregos de $2^{\mathrm{a}}, 3^{\mathrm{a}}$ e $4^{a}$ ordem. As ordens dos córregos referemse a um sistema de classificação que descreve o tamanho e a posição dos córregos nas bacias hidrográficas. Pelo que se pode observar, são todos cursos d'água com menos de 10 metros de largura. Existem 16 nascentes.

Considerando-se as medidas impostas pela Lei $\mathrm{n}^{\circ} 4.771$, relativas aos cursos d'água e nascentes, apura-se para EEC, as seguintes áreas gravadas como de preservação permanente:

\begin{tabular}{c|l|c|c}
\hline & Quantidade & Área a ser preservada & TOTAL \\
\hline Nascentes & 16 & $0,78 \mathrm{ha}$ & $\mathbf{1 2 , 4 8 h a}$ \\
\hline
\end{tabular}

\begin{tabular}{c|c|c|c}
\hline & $\begin{array}{c}\text { Quantidade } \\
(\mathrm{m})\end{array}$ & Área a ser preservada & TOTAL \\
\hline Cursos d'água & 37.501 & 30 metros de largura & $\mathbf{1 1 2 , 5 0 h a}$ \\
\hline
\end{tabular}

\subsection{Total de área de preservação permanente}

Elaborando-se a estratificação da gleba, conforme as restrições legais, obteve-se 40ha de áreas com declividade acentuada, 12,48ha de áreas de entorno de nascentes e 112,5ha de área de matas ciliares, num total de 169,40ha. As madeiras provenientes desses 169,40ha de florestas gravadas como áreas de preservação permanente (app) não devem ser consideradas indenizáveis, pois pela legislação, não é permitido o aproveitamento comercial das mesmas (não podem ser derrubadas). Seu preço, desta forma, fica restrito apenas ao próprio valor das terras correspondentes.

Numa correta avaliação, todas as áreas, inclusive aquelas que sofrem restrições de uso impostas pelas recomendações técnicas e restrições legais, devem ser 
adequadamente valoradas e indenizadas. Se não se pode admitir o "puro e simples" confisco de terras particulares, cobertas com floresta nativa, com igual razão não se pode admitir que elas sejam comparadas, e colocadas numa situação superior, às melhores terras produtivas do país (acrescidas de suas culturas e benfeitorias), rompendo-se o limiar do justo valor, levando a enriquecimento indevido do patrimônio particular em detrimento do patrimônio da coletividade (Schwenck Jr. e Azevedo, 1998).

\subsubsection{4 Área de Reserva obrigatória ou legal}

Conforme o disposto no Artigo 16, alínea "a", do Código Florestal, as derrubadas de florestas nativas (e conseqüentemente aproveitamento comercial das matas), só são permitidas desde que seja respeitado o limite mínimo de $20 \%$ da área da propriedade, com cobertura arbórea localizada, a critério da autoridade competente. Reserva obrigatória, nas regiões Leste Meridional (que compreende o Estado de São Paulo), Sul e Centro-Oeste (esta na parte sul), ficando claro, ademais, que a reserva obrigatória (legal) de $20 \%$ atinge qualquer floresta de domínio privado.

O assistente técnico representante da Fazenda do Estado alertou o MM. Juiz quanto à necessidade de se excluir o valor da cobertura vegetal da reserva obrigatória, quando da valoração final da propriedade. Apesar disso, o magistrado refutou o argumento, afirmando que “.... a restrição legal tão só impede o corte, visando a preservação da mata natural e não implica em perda da propriedade".

Entretanto, a reserva obrigatória deveria ter sido calculada e também considerada no laudo judicial. Se existem impedimentos de exploração, não há porque considerar o valor da madeira desta área, na composição do valor total da mata.

A área total da Fazenda Paraíso (at) era de 3.023,97 alqueires ou 7.318 hectares e, portanto, os $20 \%$ da área total, que constituiriam a reserva obrigatória (ro), segundo o Código Florestal, significariam 1.463,60ha. 


\subsubsection{Valor total da cobertura vegetal}

Além dos 2.176,10ha da EEC referentes à área da gleba a ser desapropriada, a Fazenda Paraíso possuía outros três fragmentos florestais (ff), que conforme os autos do processo de desapropriação, somavam 144,57ha de floresta natural. Estes fragmentos, somados à floresta da gleba da EEC, resultariam na cobertura florestal total da fazenda de 2.320,67 hectares (ct).

Considerando-se então as áreas de restrições de corte de floresta, o cálculo razoável para o "Valor Total da Mata" (VTM), seria assim composto:

\section{VTM $=$ apcg. vtmh}

Sendo:

$\operatorname{apcg}=\mathbf{a p c}-\mathbf{f f}$

apc $=\mathbf{c t}-$ aic

aic $=$ ro + app

onde:

vtmh é o valor total da madeira, por hectare;

apcg é a área passível de corte da gleba a ser desapropriada;

apc é a área passível de corte da fazenda;

ff é a área de fragmentos florestais existentes na fazenda, porém, não faz parte da gleba a ser desapropriada;

ct é a cobertura florestal total da fazenda Paraízo;

aic é a área com impedimento de corte;

ro é a área da reserva obrigatória;

app é a soma das áreas de preservação permanente da gleba. 
Assim, o valor total da mata (VTM), obtido neste estudo através do produto entre a área passível de corte da gleba a ser desapropriada (543,10ha) e o valor total do hectare de mata ( $R \$ 3.495,60 /$ ha) é de $R \$ 1.898 .460,36$.

É importante ressaltar, que esse valor é relativo a comercialização da madeira existente nas áreas de corte permitido da gleba, para pagamento á vista. No entanto, caso o corte fosse realizado, sabe-se que o proprietário seria pago, conforme a retirada da madeira, num prazo que poderia demorar alguns anos.

\subsection{5 $O$ valor da terra nua}

Por comparação com o valor de propriedades da região, o perito estipulou o valor do hectare da "terra nua" da gleba a ser desapropriada em Cr\$20.006,40 ou R\$ $2.494,03$.

O valor médio apontado por Florestar Estatístico (2003), para o hectare de terra nua na Região do Médio Paranapanema, onde está localizada a gleba em questão, é R\$ $4.294,74$ reais por hectare (vtnh), referente a terras para reflorestamento. Comparandose o preço atual da terra da região, com o valor atualizado do hectare apontado pelo perito ( $\mathrm{R} \$ 2.494,03 / \mathrm{ha}$ ), pode-se observar que o valor estipulado pelo perito é $42 \%$ menor do que o valor de mercado atual. Muito provavelmente, na época da elaboração do laudo e da desapropriação da gleba (02/78), as terras da região deveriam estar passando por um período de desvalorização, provocado pela diminuição da cultura de café, que cedeu espaço para culturas de seringueira na região.

\subsubsection{Estimativa do valor total da propriedade}

O cálculo do valor total da propriedade elaborado pelo perito judicial foi o produto entre valor obtido do hectare de terra nua, pela área total da gleba (2.176.10ha). Procedimento normal.

Para o valor da Total da cobertura vegetal, o perito procedeu da mesma maneira, multiplicando o valor do hectare de mata pela área total da gleba, desconsiderando toda 
e qualquer restrição imposta pela legislação ambiental. Somou o valor total de terra nua com o valor total da mata, acrescentou $5 \%$ referentes ao que denominou de "valor de preservação da fauna", e chegou a um valor final de Cr\$169.848.141,00, que corresponde a $\mathrm{R} \$ 21.173 .605,67$.

Fazendo-se os cálculos com valores estimados neste estudo, considerando as restrições legais: somando-se o valor total da terra nua $(\mathrm{R} \$ 4.294,74 \times 2.176,10=\mathrm{R} \$$ 9.345.788,71), somando-se o valor total da mata $(\mathrm{R} \$ 1.898 .460,36)$ acrescentando-se $5 \%$ do que seria o valor da preservação da fauna $(562.212,20)$, obtém-se o valor total da gleba de $\mathrm{R} \$ 11.806 .456,28$. Um preço total da propriedade $44,24 \%$ menor do que o encontrado pelo perito judicial. 


\section{CONCLUSÕES}

A estimativa de volume total obtida pelo método de quadrantes não apresentou diferença estatisticamente significativa, quando comparada com o valor obtido pelo método de parcelas. Essas estimativas, relativas das espécies de valor comercial apresentaram diferenças sempre menores do que $3 \%$.

Esses resultados indicaram, que considerando o modelo utilizado, o método de quadrantes configurou-se como uma boa ferramenta para a estimativa de volume, considerando-se ainda, maior facilidade e menor tempo de implantação (menor custo), e a eficiência na amostragem florística.

Fazendo-se os cálculos com valores estimados neste estudo, considerando as restrições legais: somando-se o valor total da terra nua $(\mathrm{R} \$ 4.294,74 \times 2.176,10=\mathrm{R} \$$ 9.345.788,71), somando-se o valor total da mata ( $\mathrm{R} \$ 1.898 .460,36)$ acrescentando-se $5 \%$ do que seria o valor da preservação da fauna $(562.212,20)$, obtém-se o valor total da gleba de R\$ $11.806 .456,28$. Um preço total da propriedade $44,24 \%$ menor do que o encontrado pelo perito judicial, o que resultaria numa economia de $R \$ 9.367 .149,39$ (Nove milhões, Trezentos e Sessenta e Sete Mil, Cento e Quarenta e Nove Reais e Trinta e Nove Centavos), aos cofres do Estado..

A obtenção do valor da gleba, neste estudo, envolveu muito mais do os resultados dos levantamentos. Os resultados da avaliação sistemática da área através de levantamento da fragilidade do solo, a avaliação e mensuração dos cursos d'água e o estudo de geomorfologia, somados aos dados do levantamento florestal e da legislação ambiental, contribuíram decisivamente para a obtenção do valor próximo daquele que o mercado está disposto a pagar. 
Dessa maneira, fica patente a necessidade da atuação de equipes multidisciplinares na elaboração dos laudos. O custo de estudos bem embasados tecnicamente e feitos por especialistas, certamente será coberto pelo pagamento de "justas indenizações", produzidas por valorações corretas. 
ANEXOS 


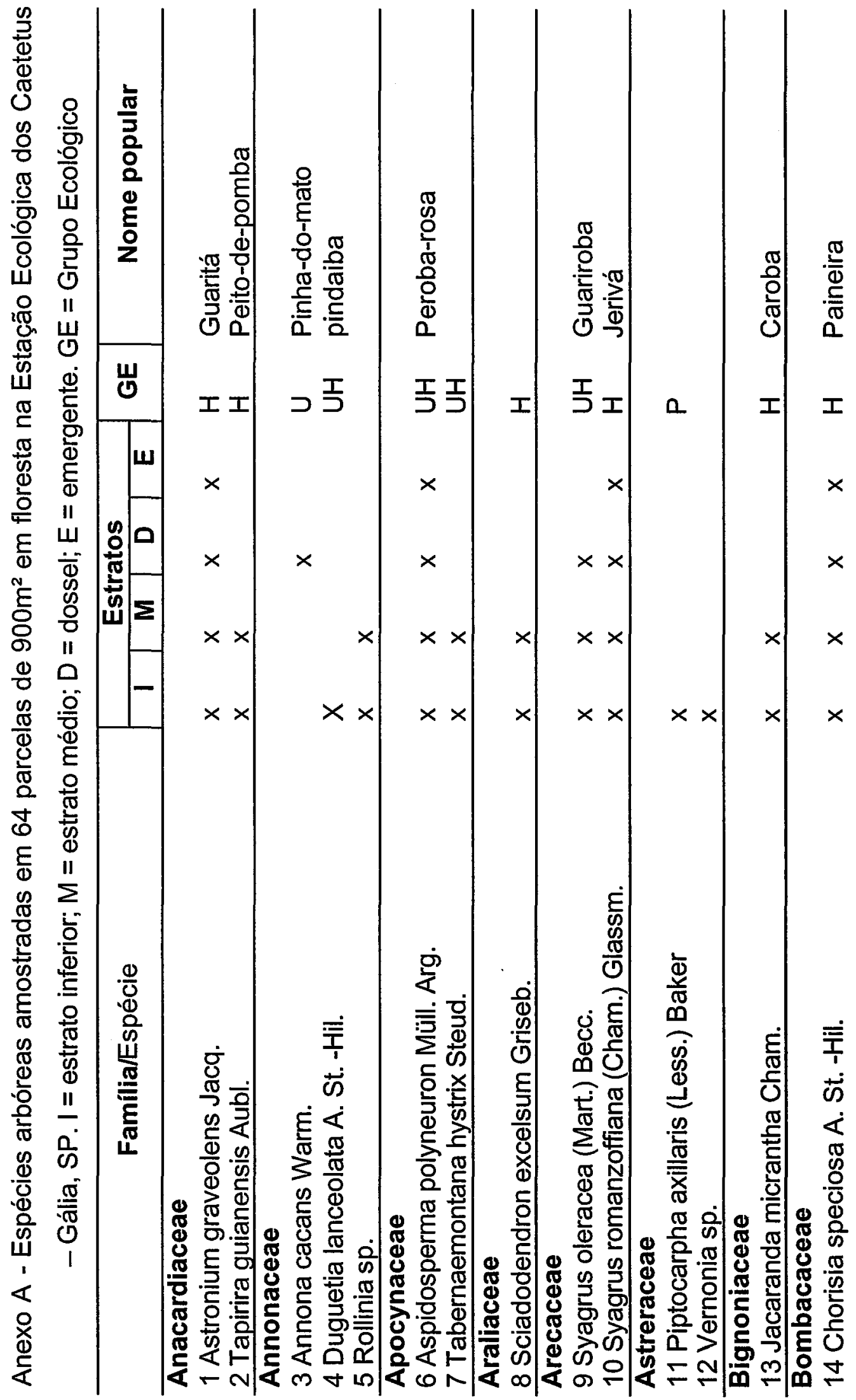




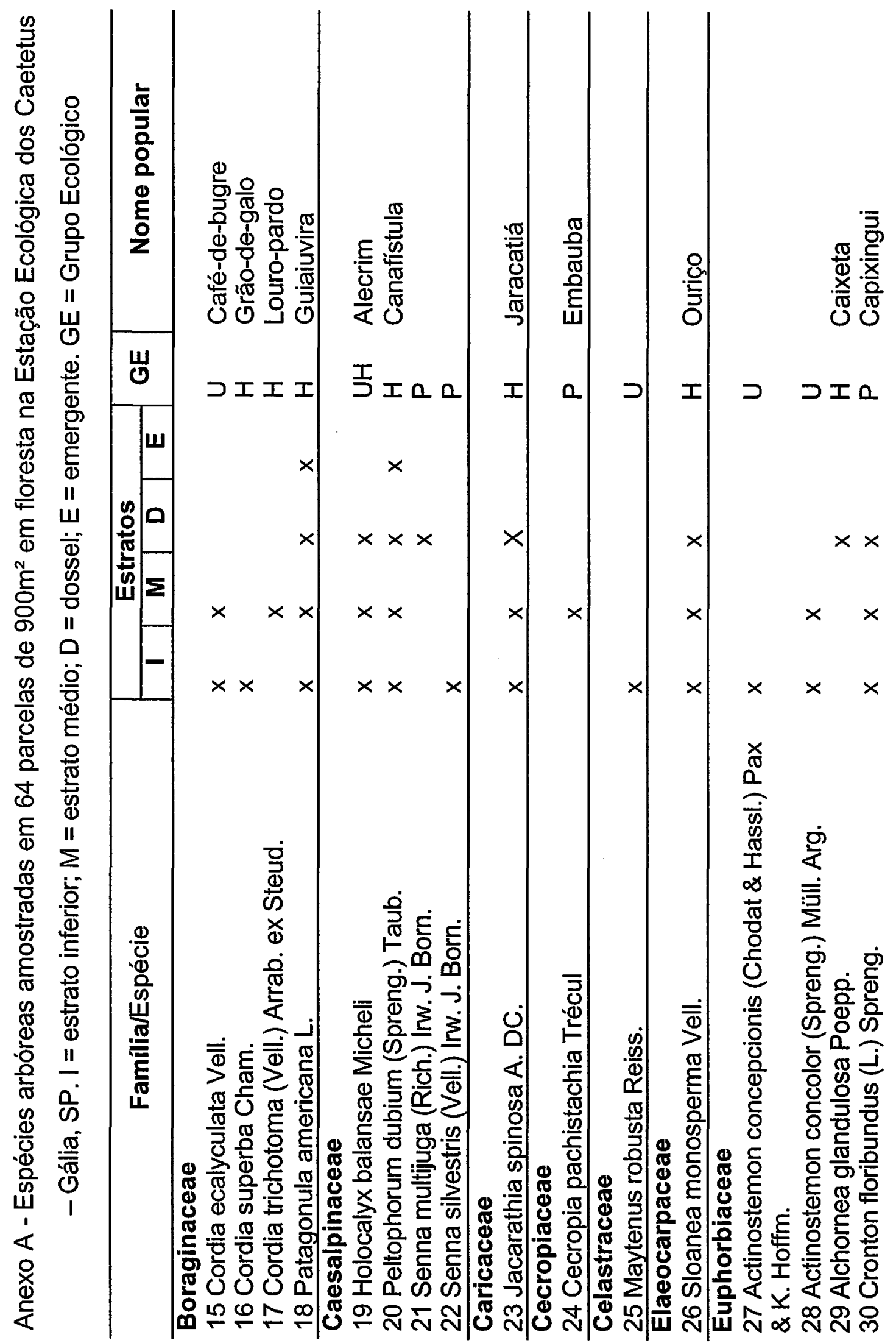




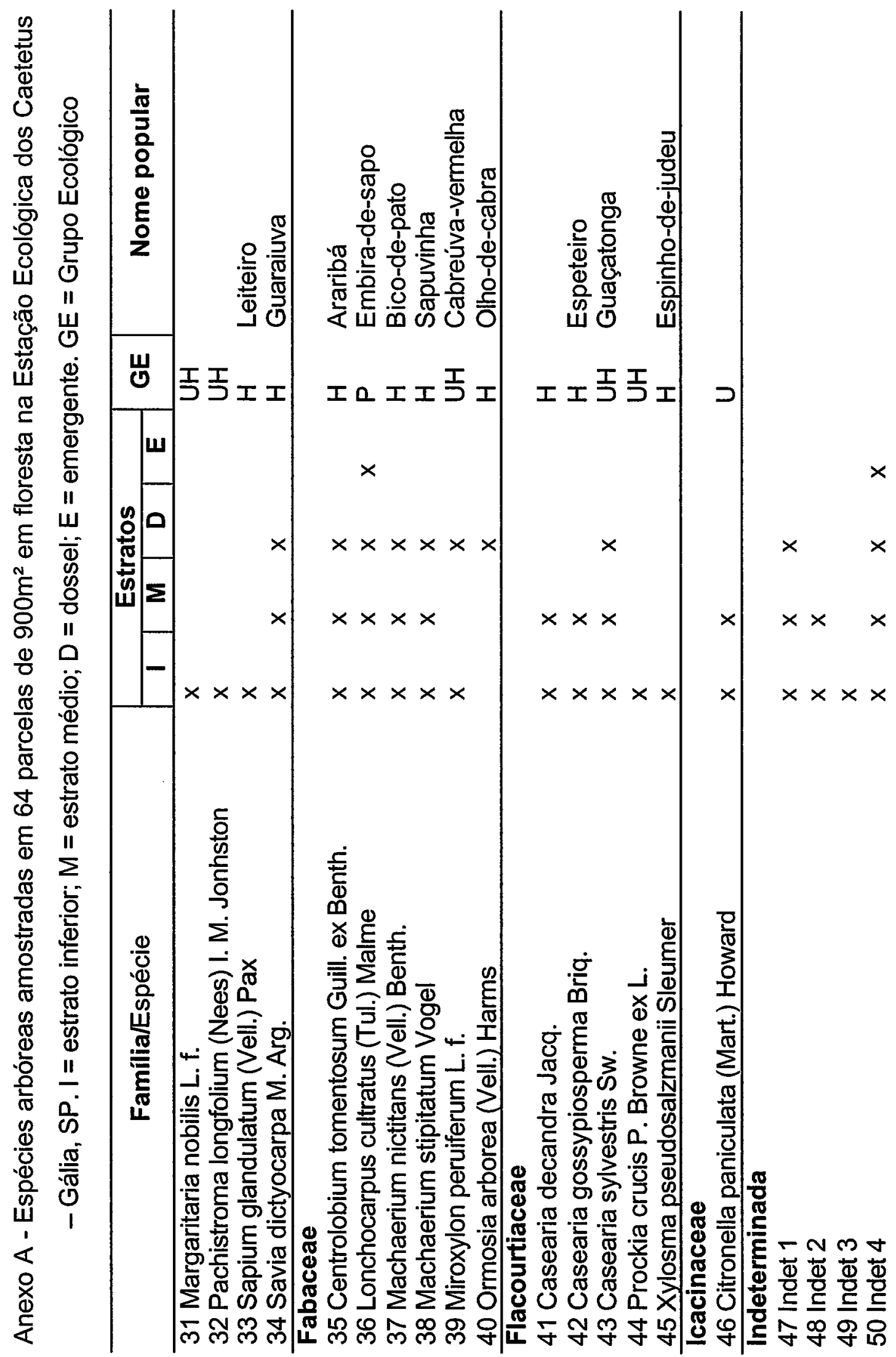




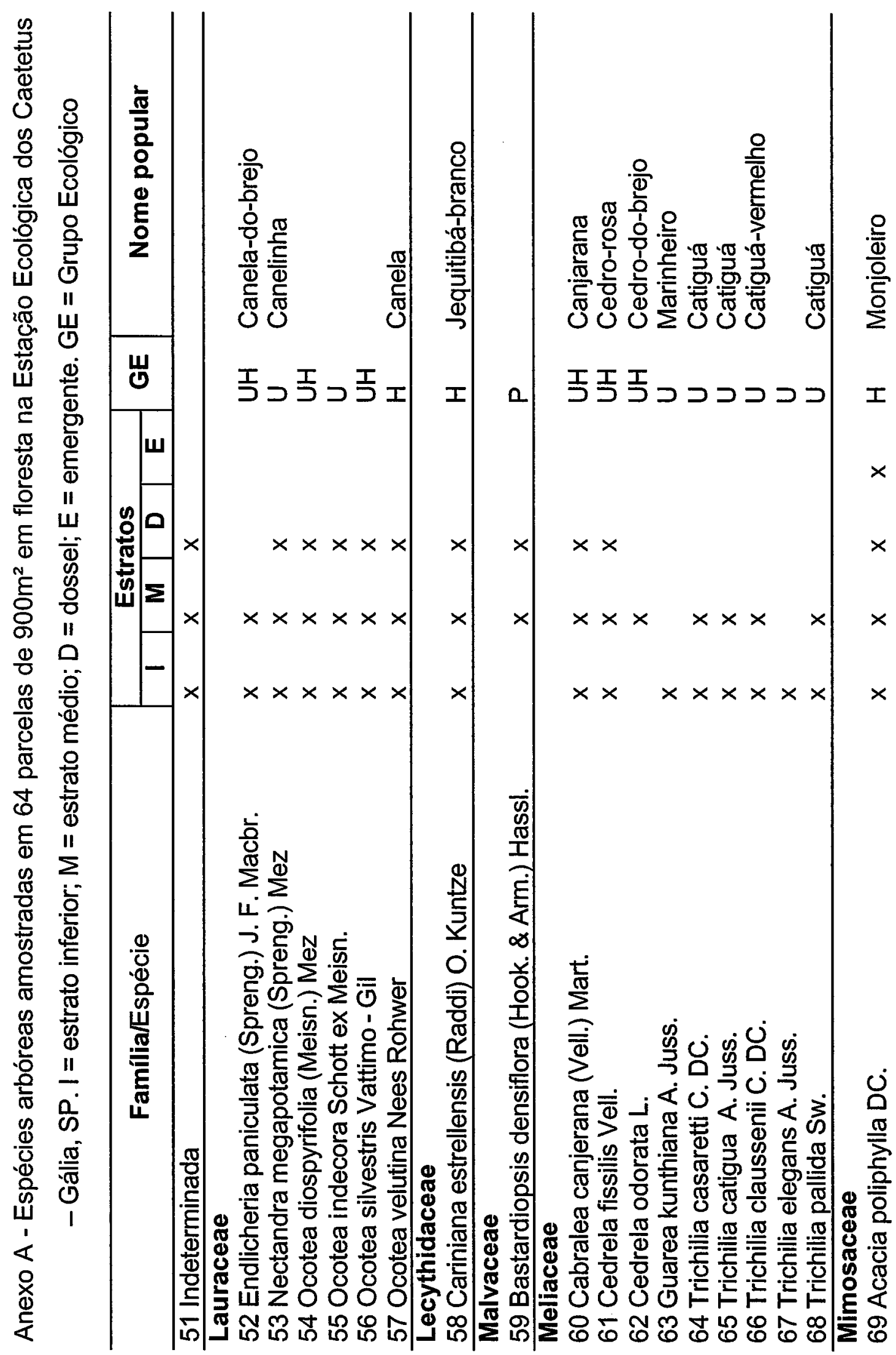




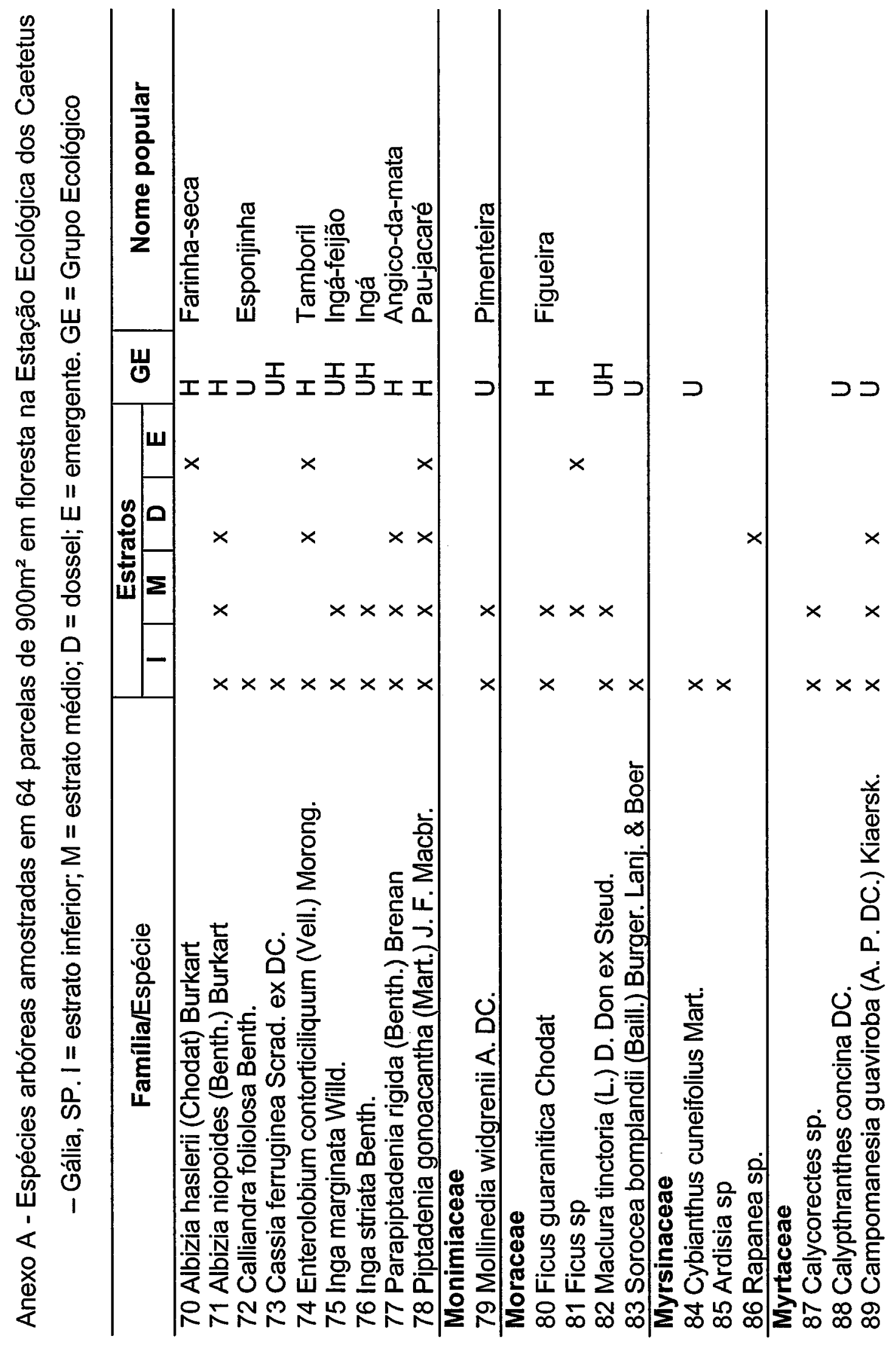




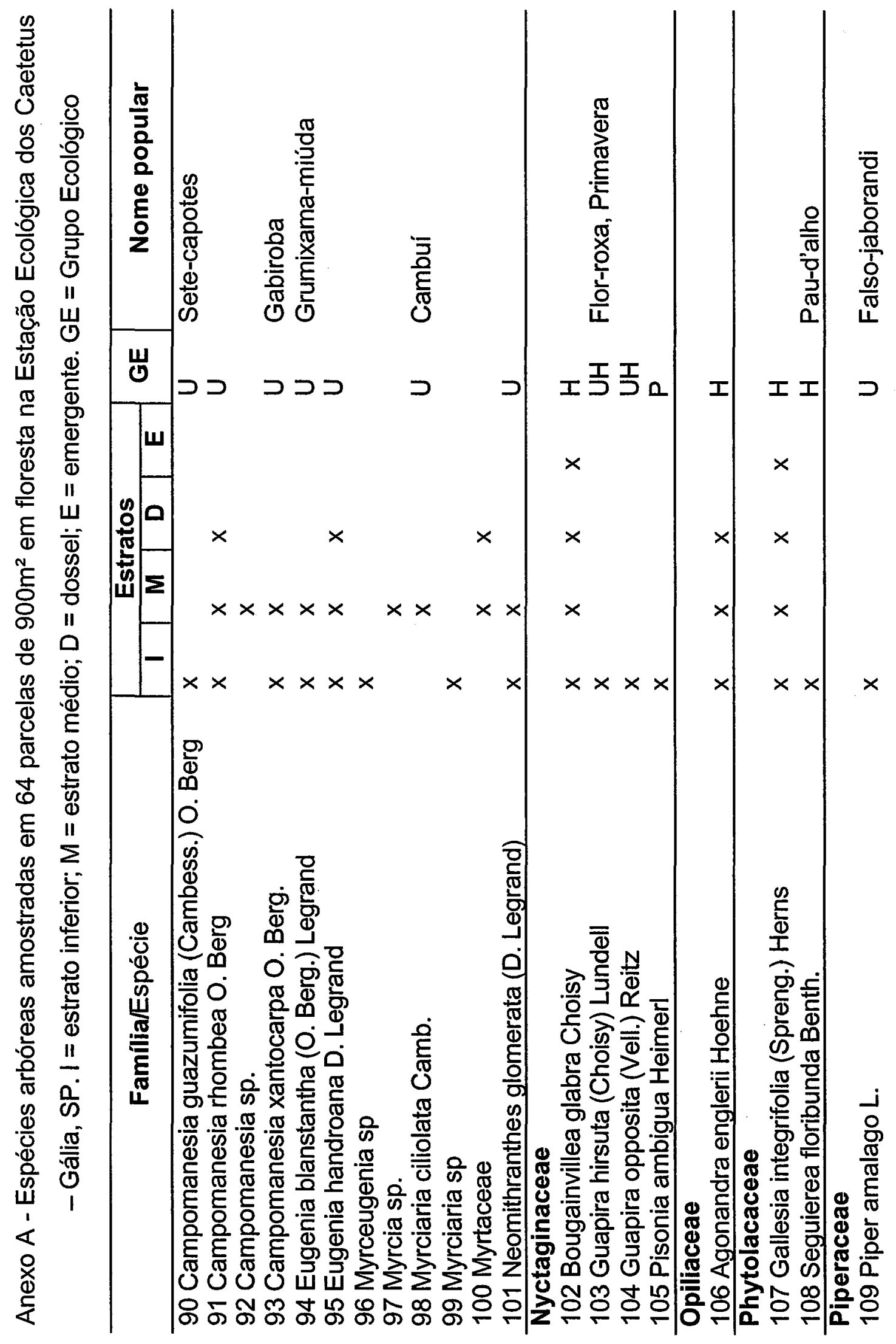




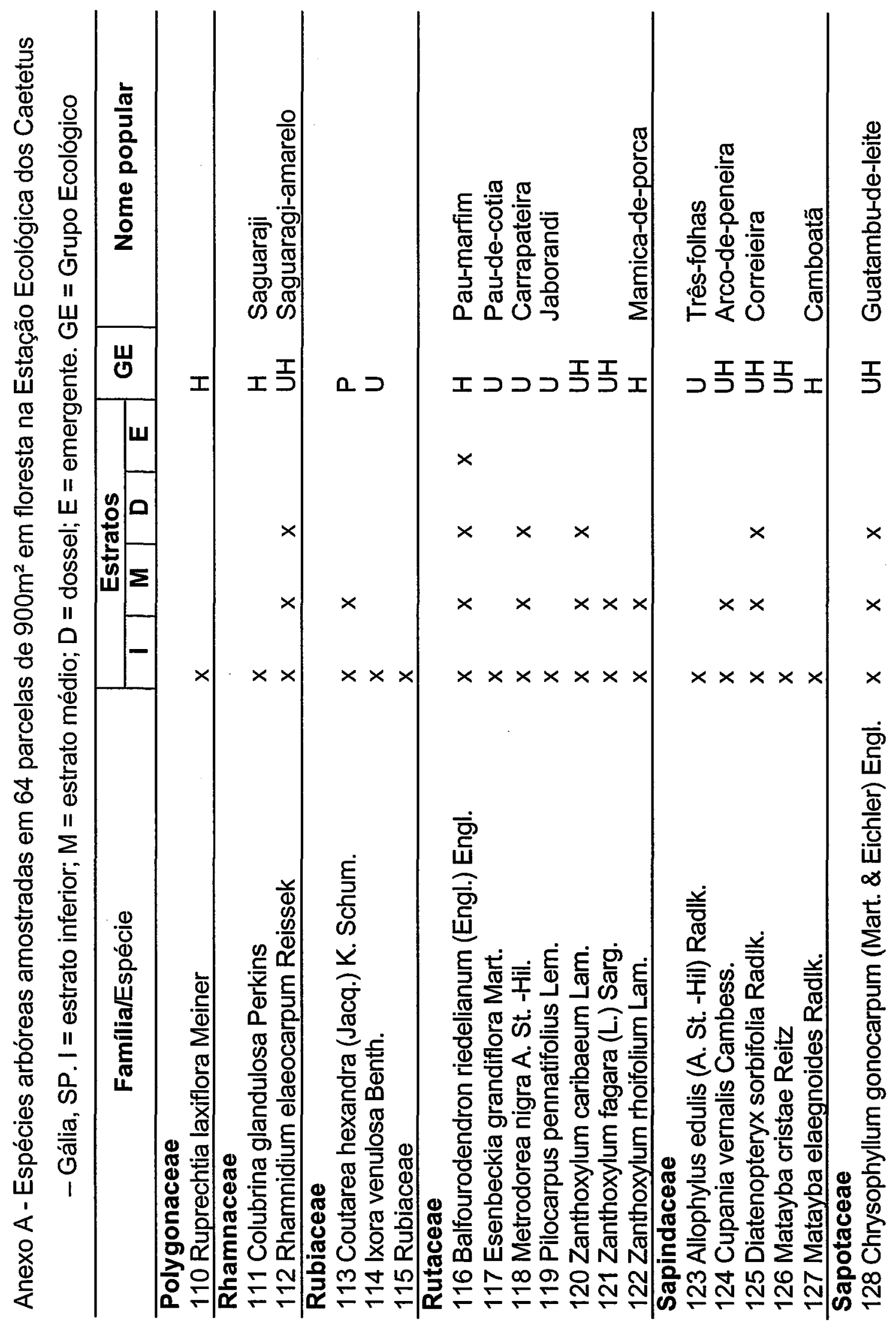




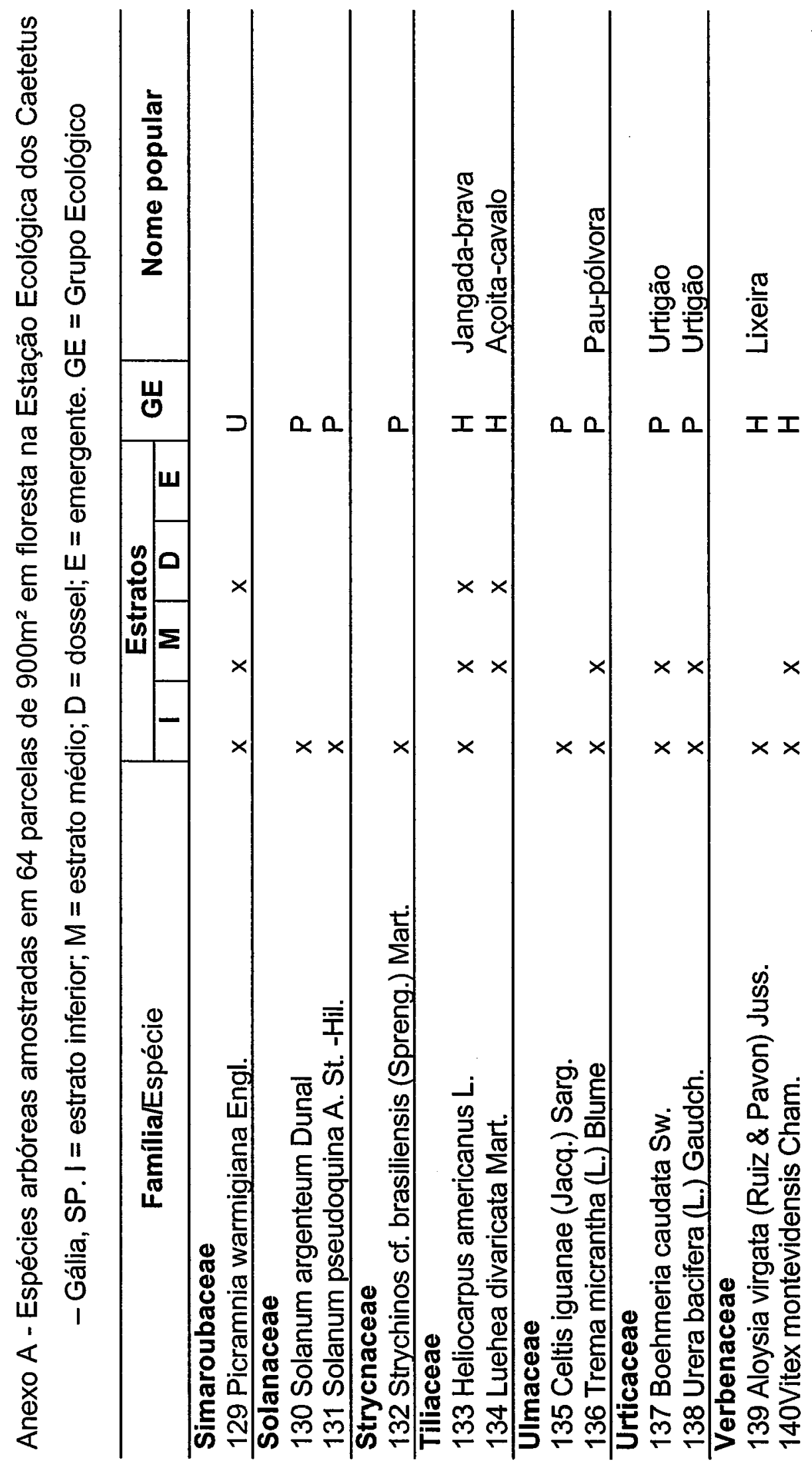




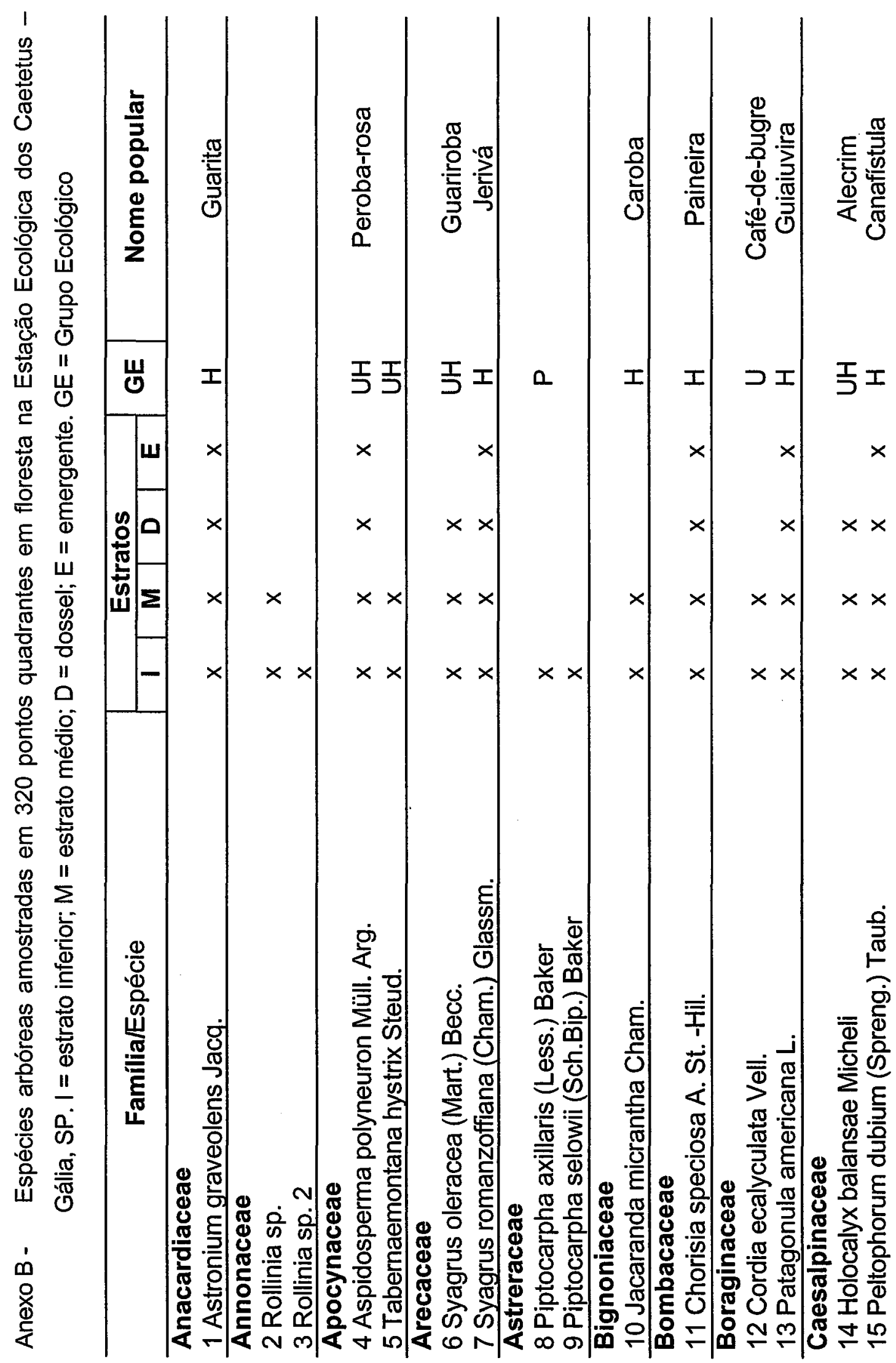




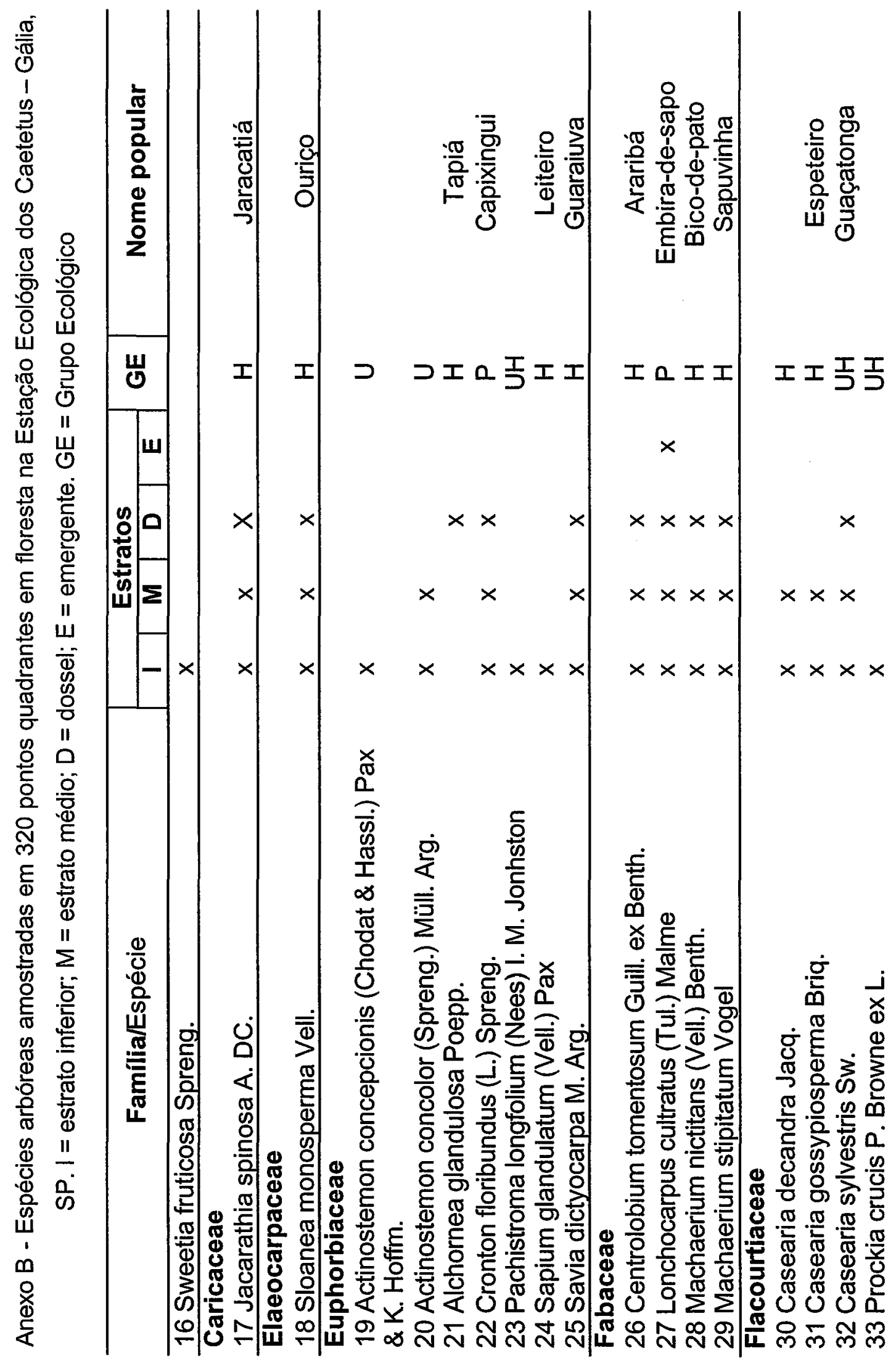




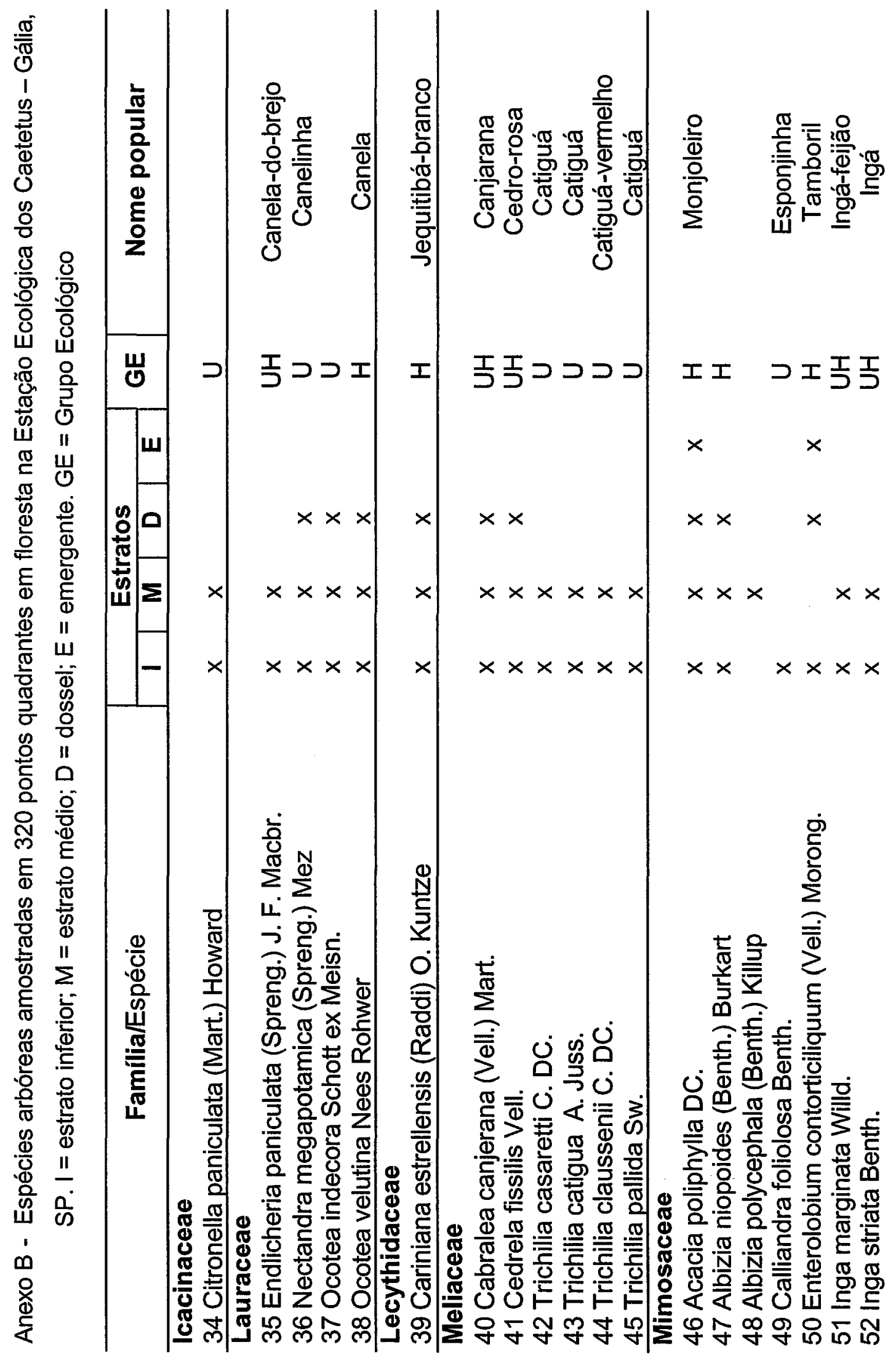




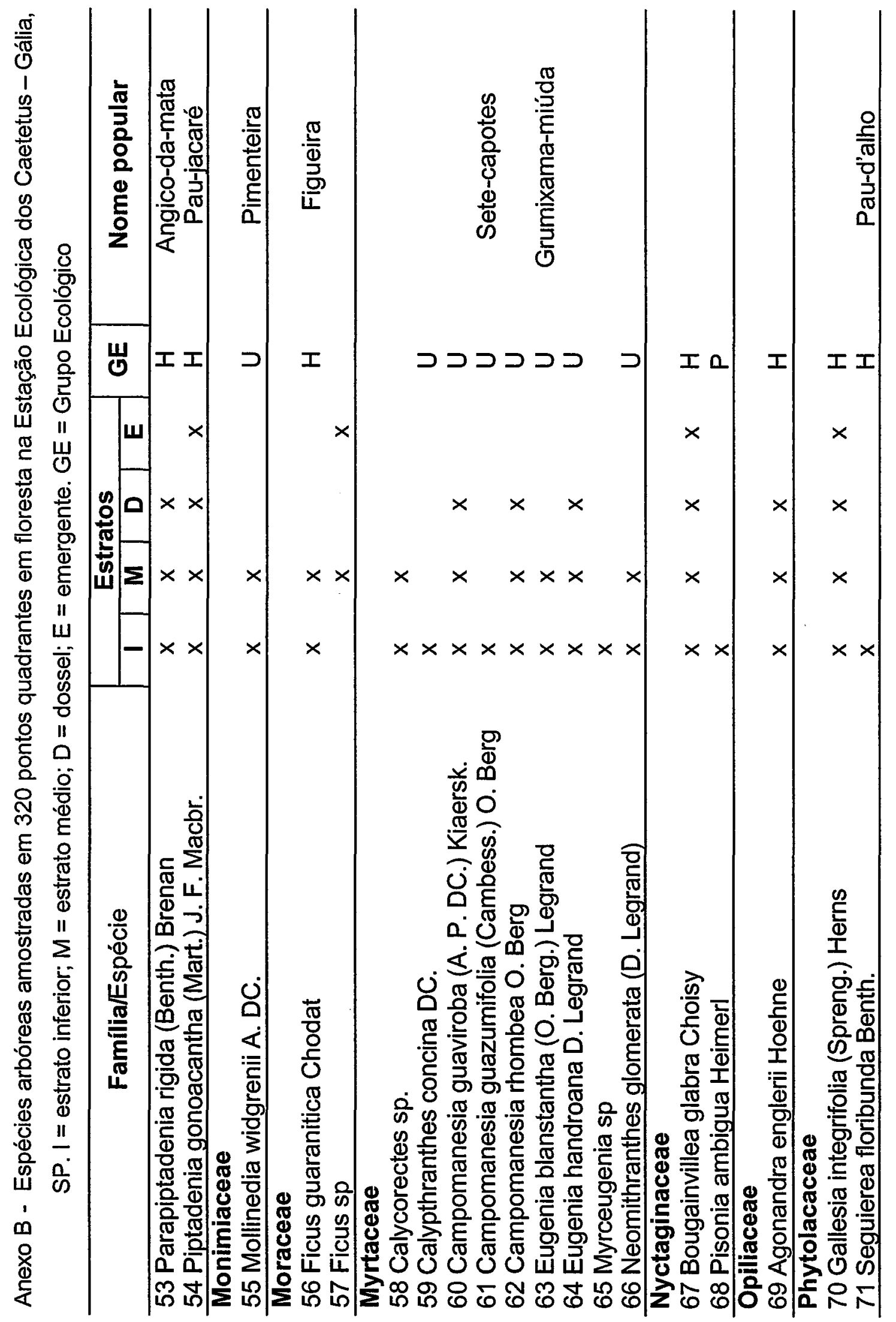




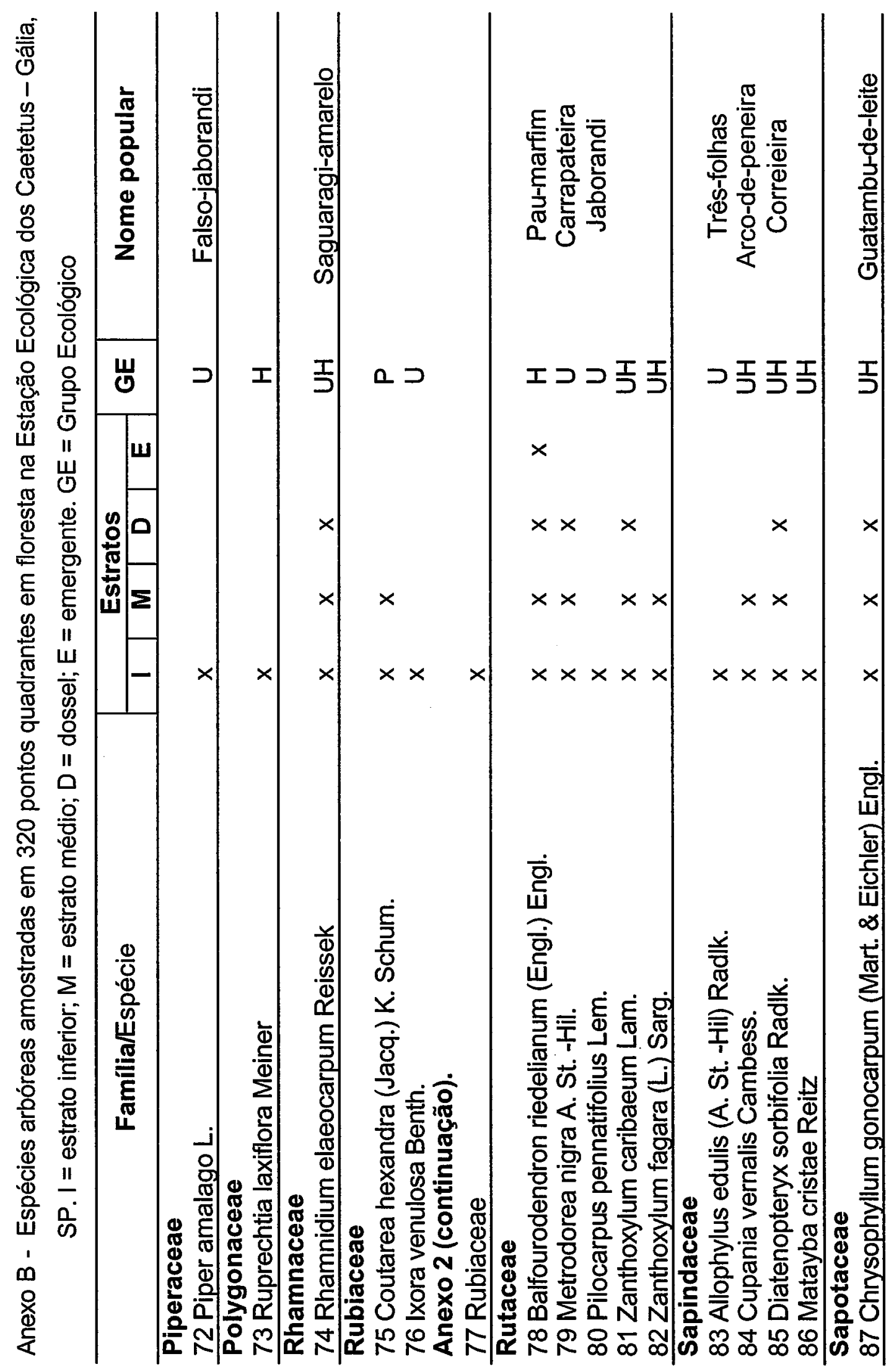




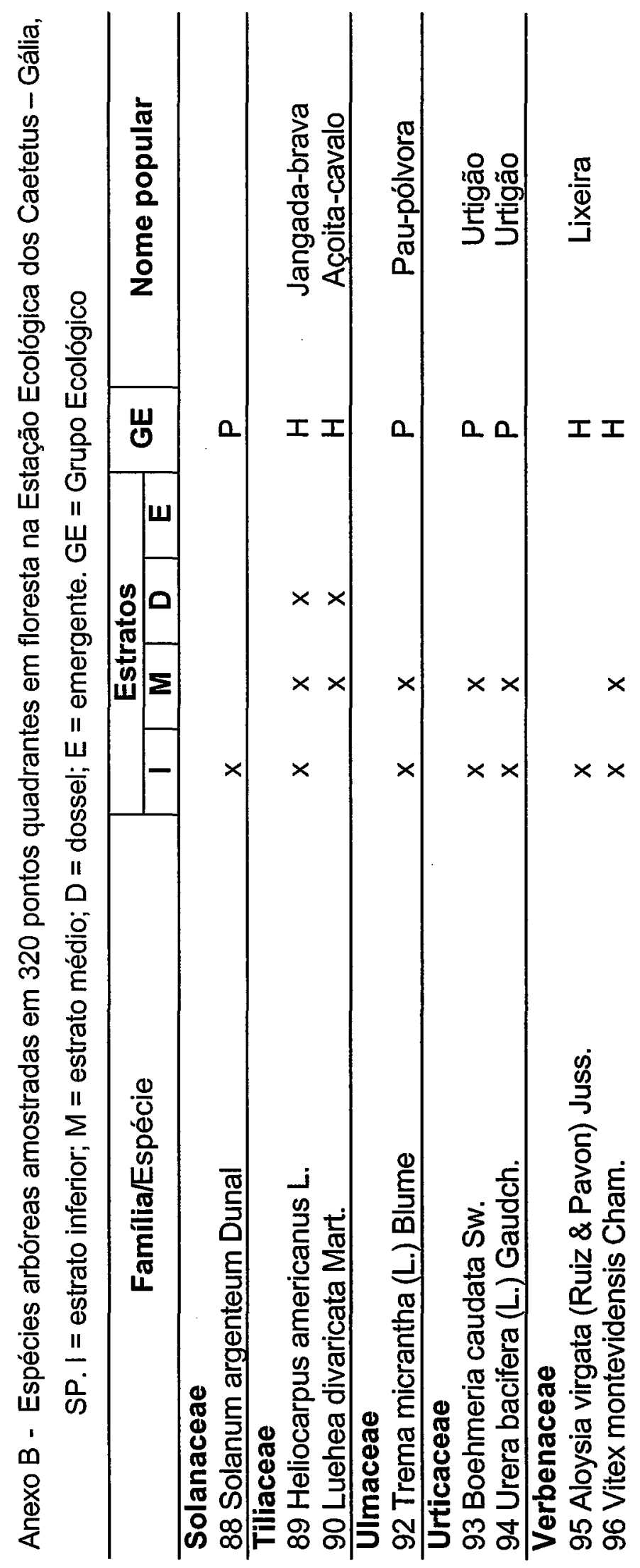




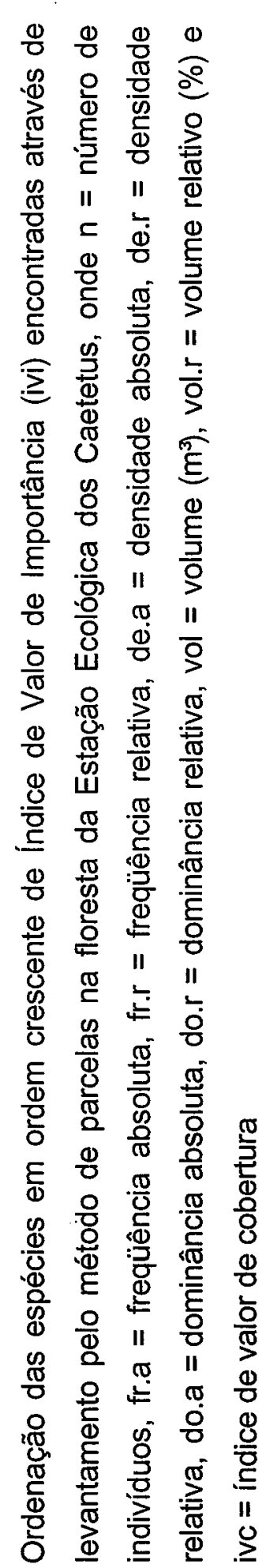

0

產

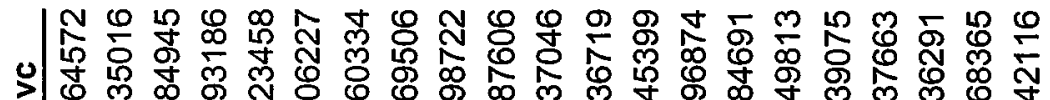
$\geq$ 芩 $\delta \div=\infty$ का

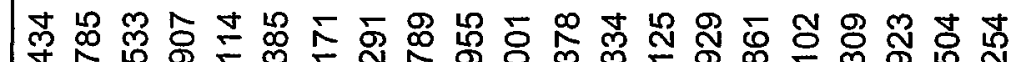
$\checkmark$ 岕守

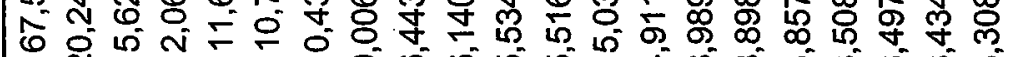

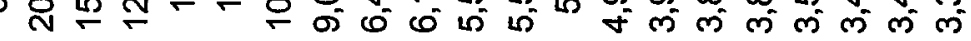
身莳志웡

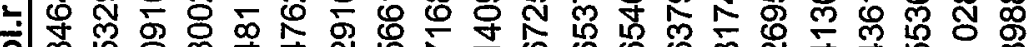

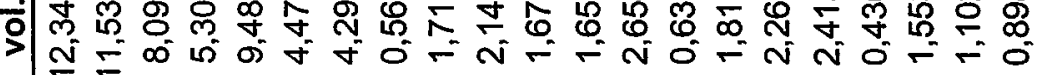
央仝 D

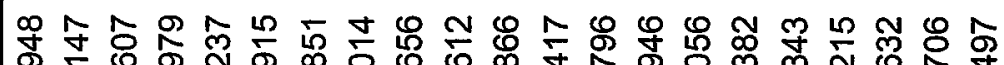
ᄂ 응

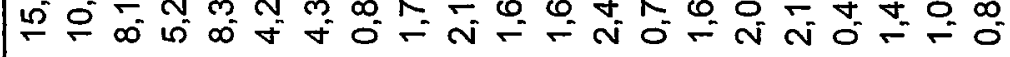

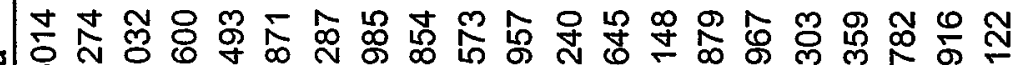
๙. Am

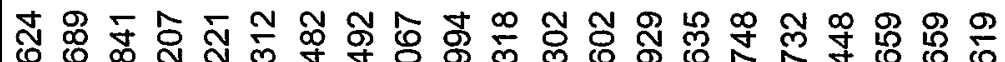
ᄂ

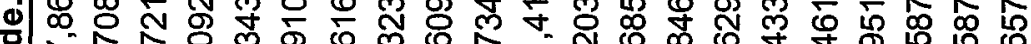
年 $\bar{\varphi}$ - N $^{\circ}$ m $\infty$ 舟

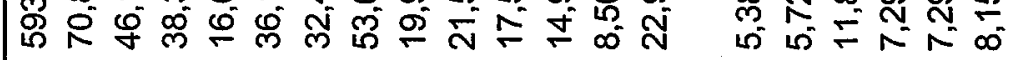

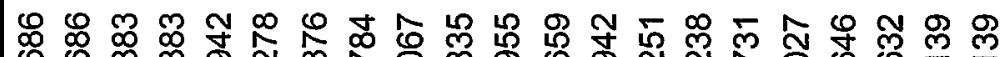
$\div$ ᄂ

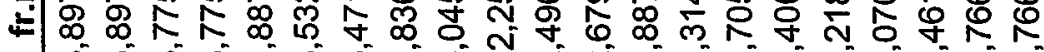
m लm लm m m m N N

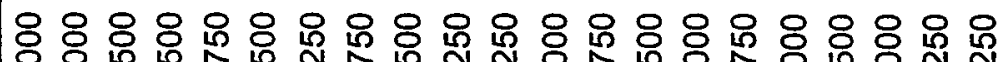

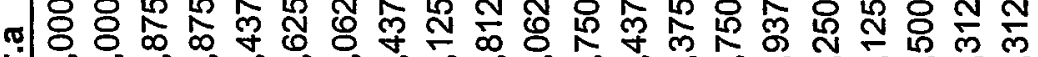
*

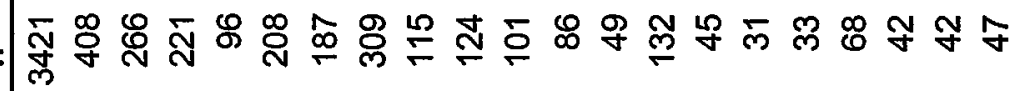

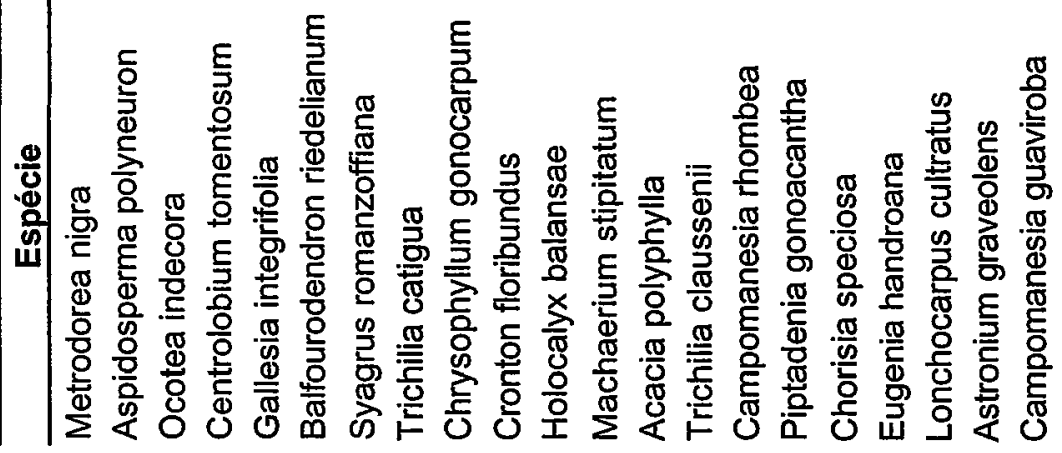




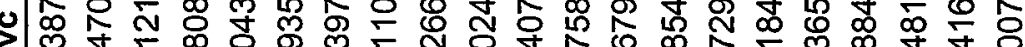
స్ $\bar{m}$ 的

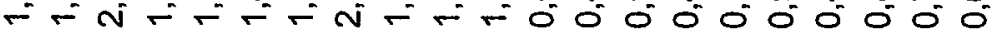

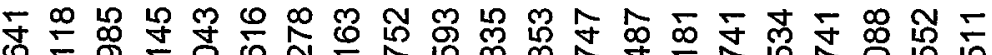

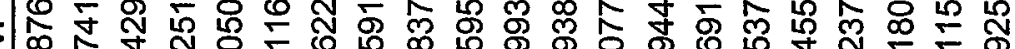

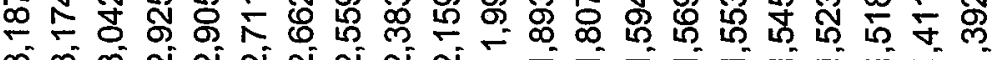

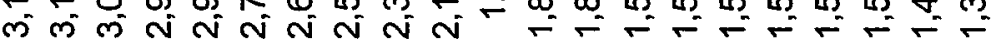

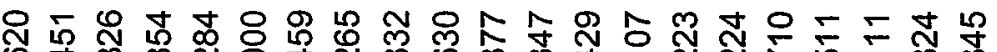
过

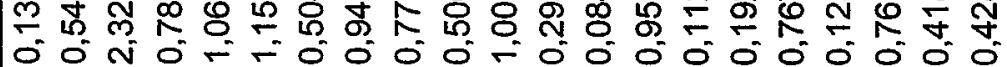
సิูป ก 万人

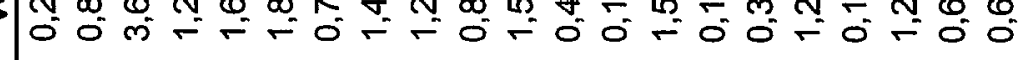

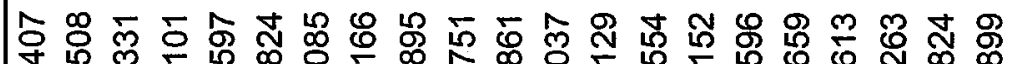

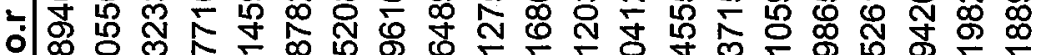

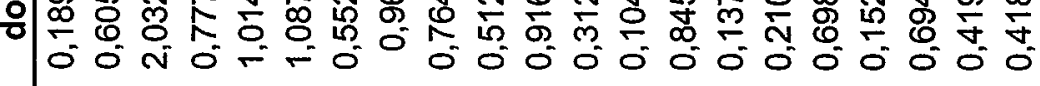

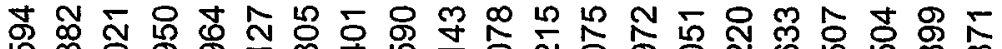

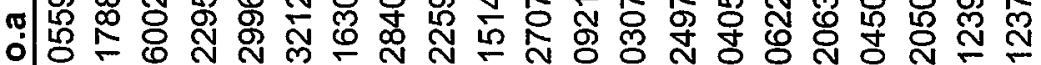
일 万

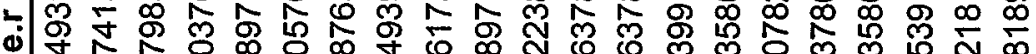

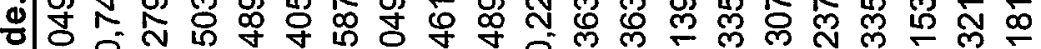

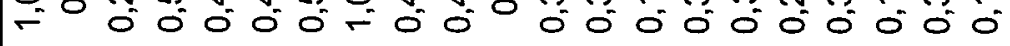
m ๑

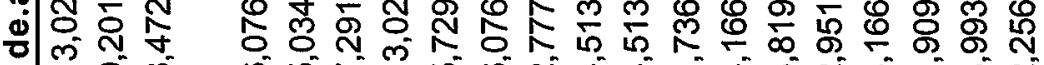
न ชัํํㅇำ ᄂ 4

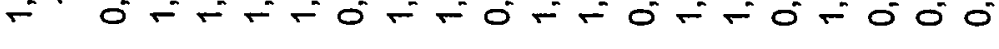

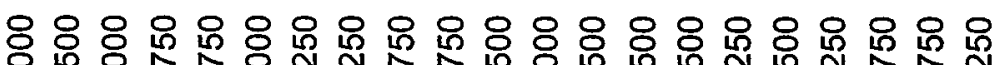

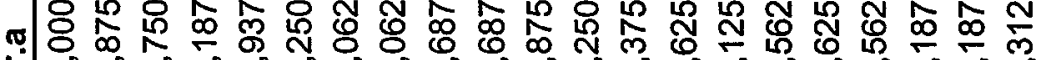

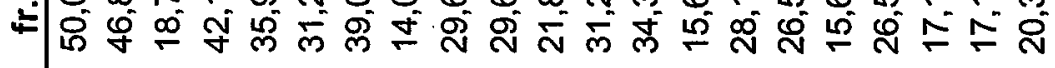

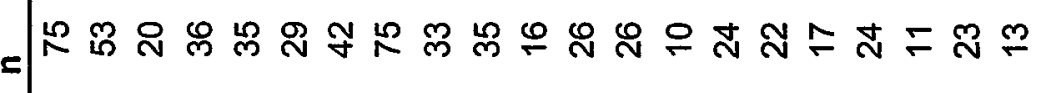
$\frac{0}{2}$
$\frac{1}{0}$
$\frac{0}{8}$
0
$\frac{1}{0}$
$\frac{1}{0}$
$\frac{1}{>}$

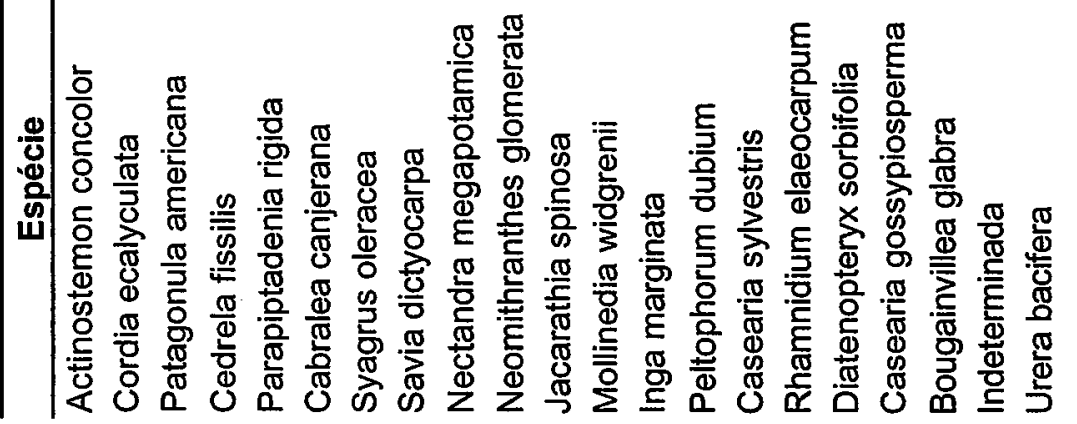




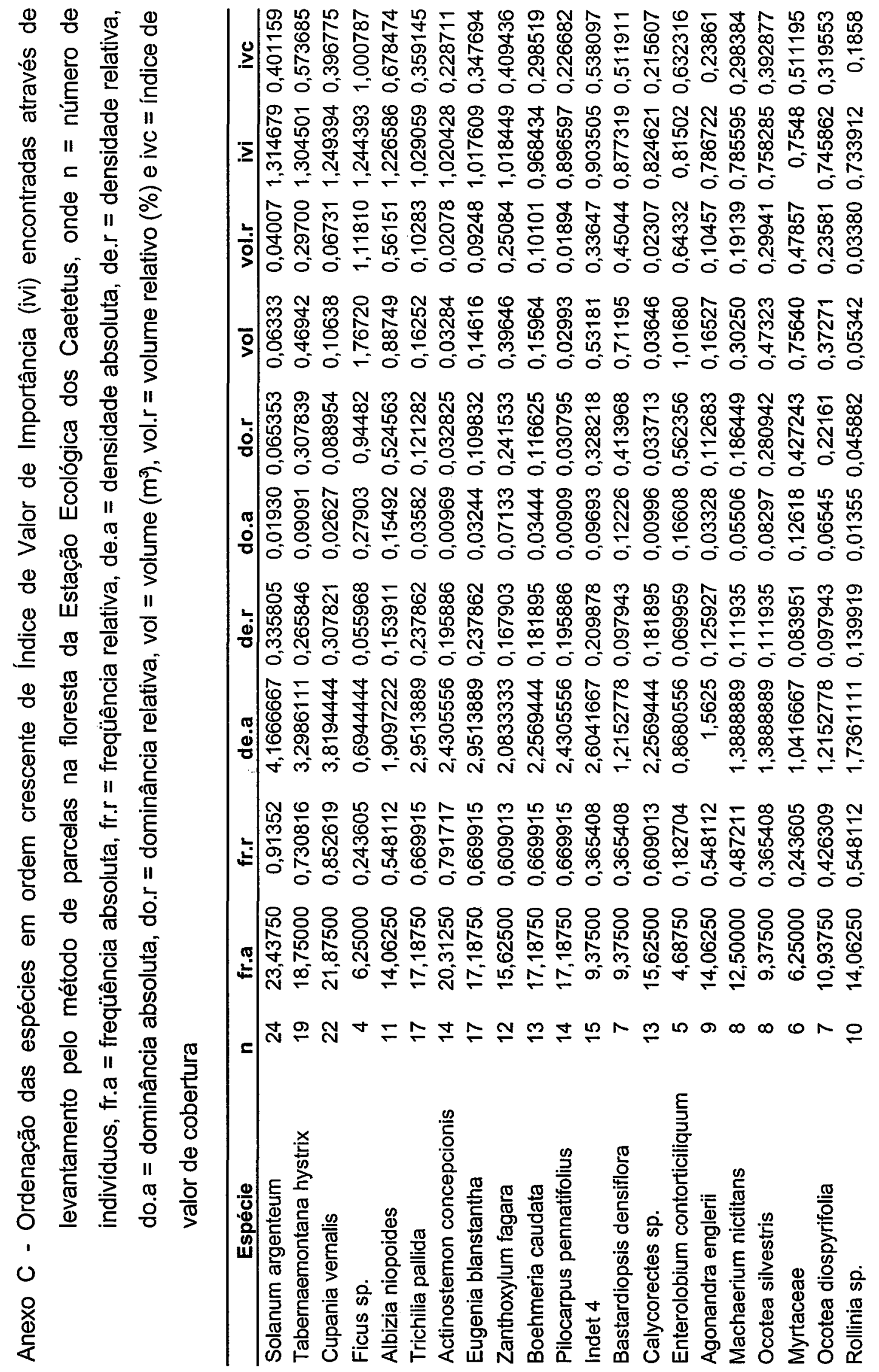




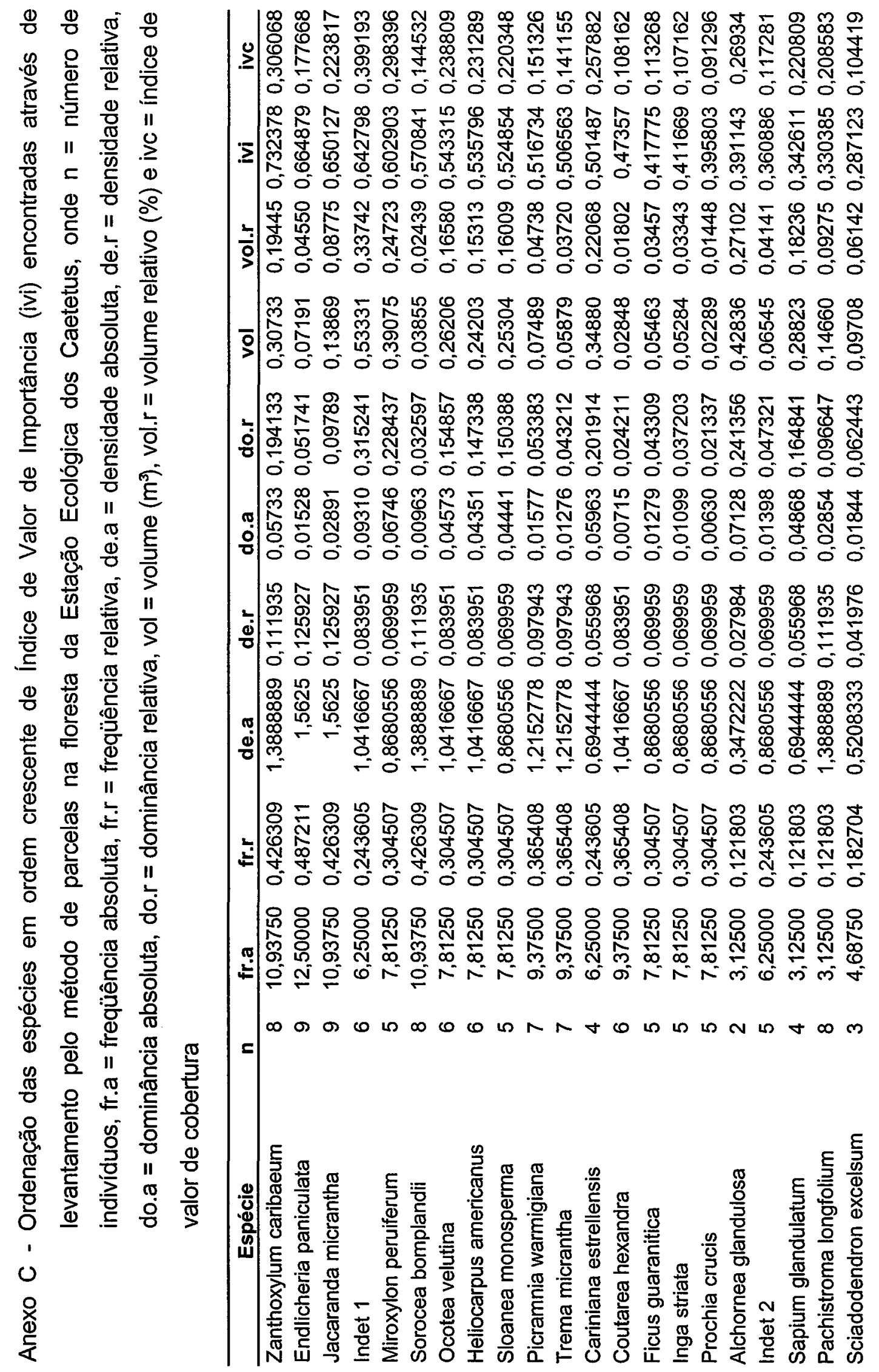




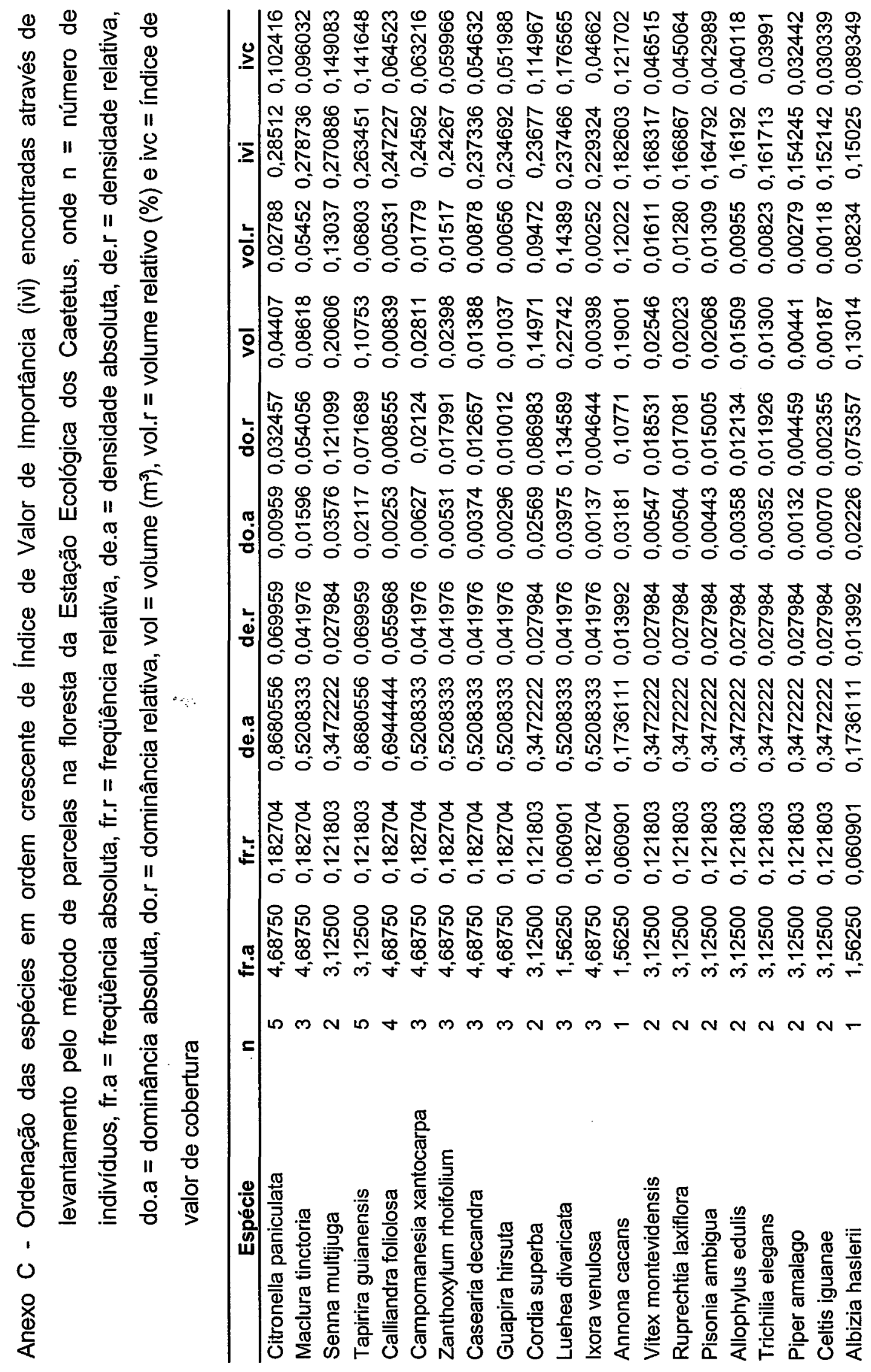




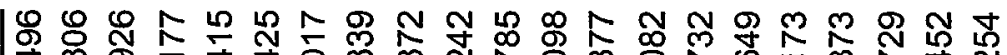

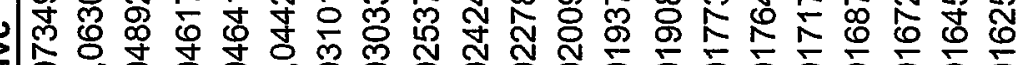

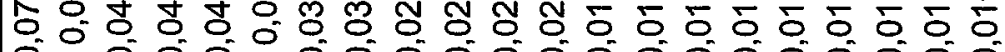

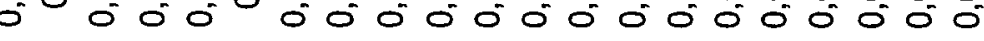

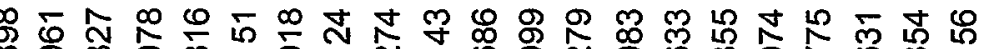

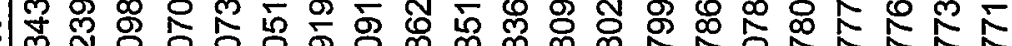

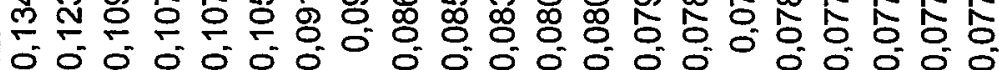
ஜ $\%$ 舟

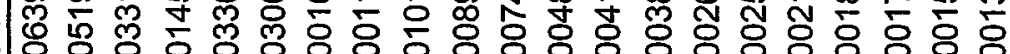
O

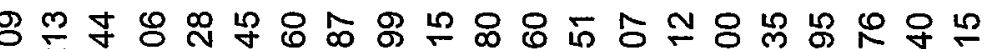

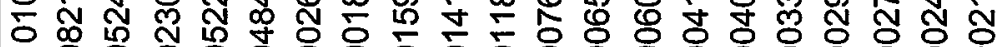

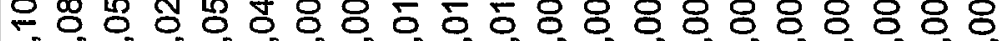

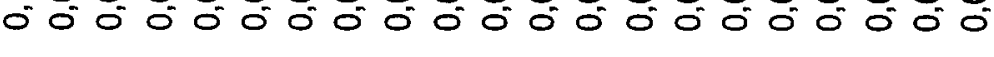

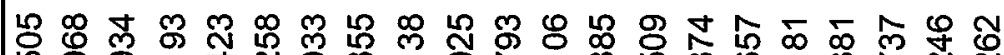
ᄂ 음 你尔

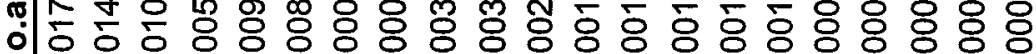

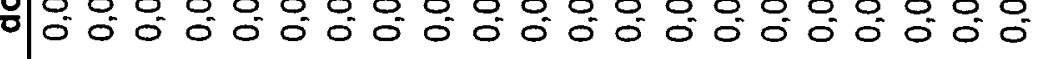
รู ชิ मे म्ल / \& FFF 든ำFFFFFFFFFFF

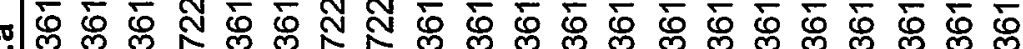

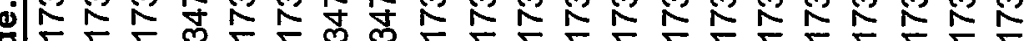

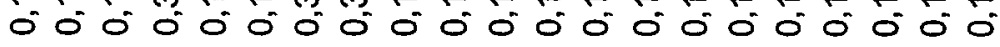

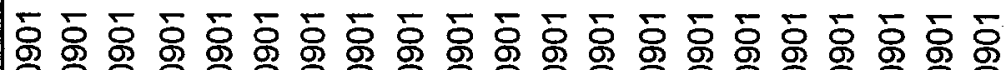

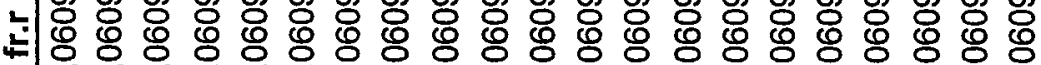

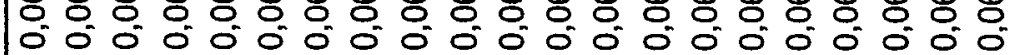

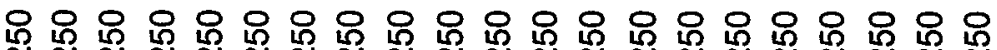

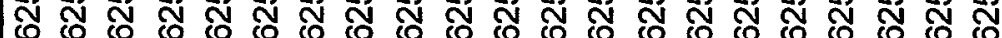
*

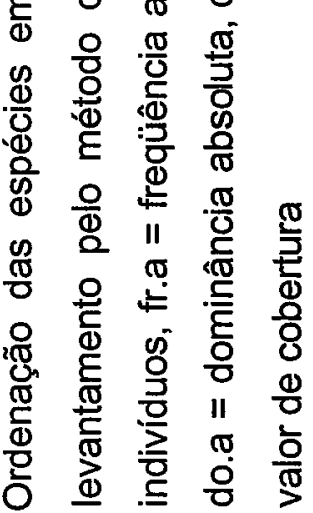

0

$\frac{0}{4}$

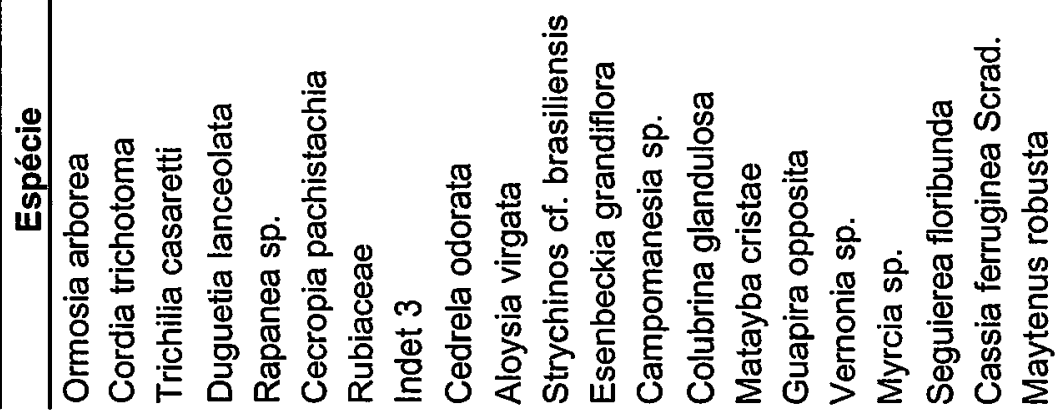




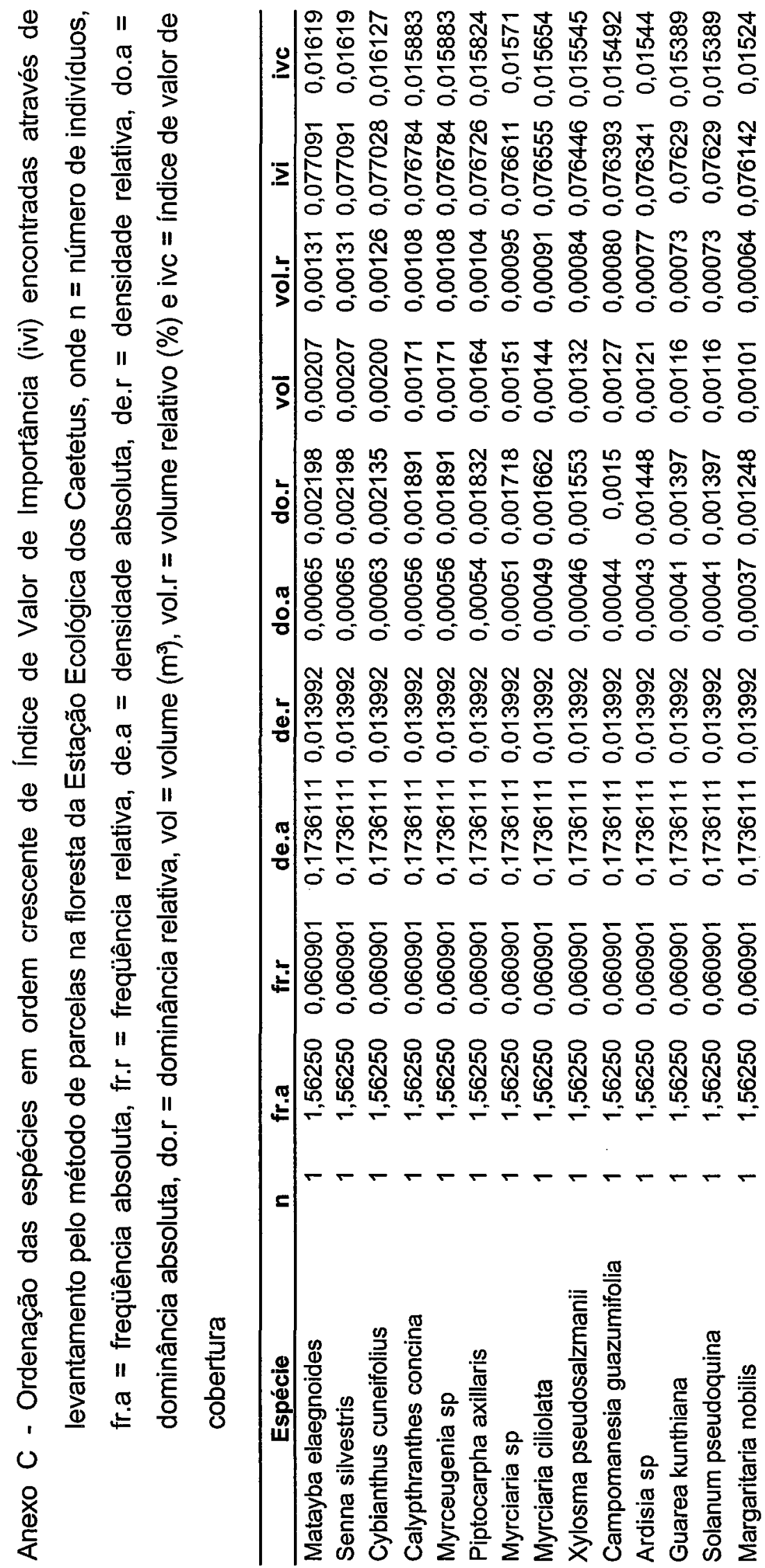




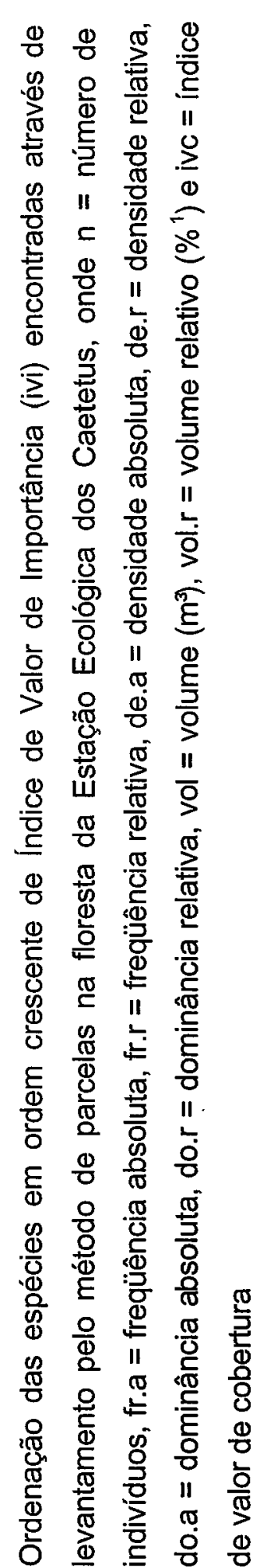

'

옹

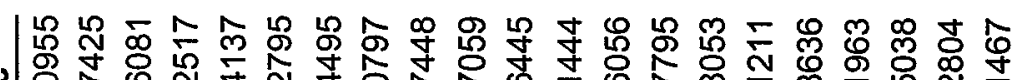

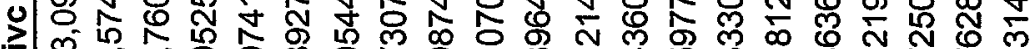

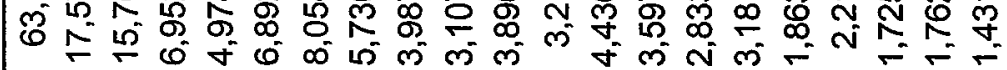

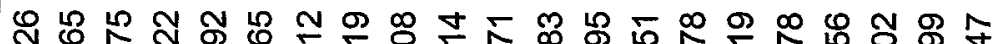

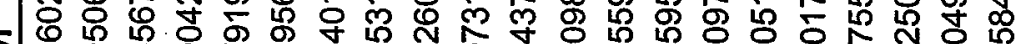

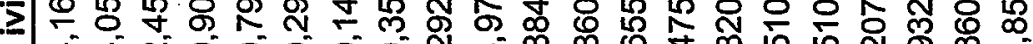
过过 N ఇ 늉ำ 이으. N

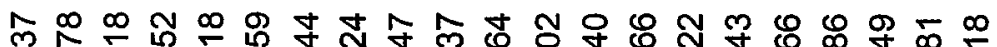

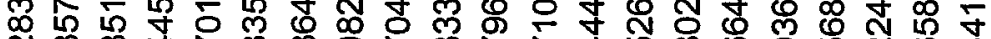

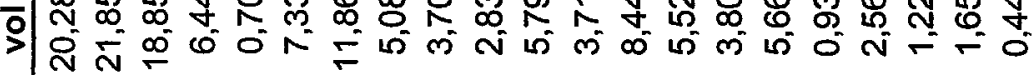

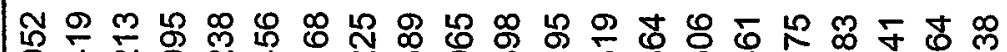
ᄂ 웅 to

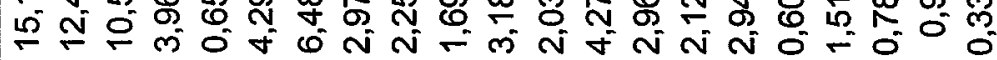
。 ำ

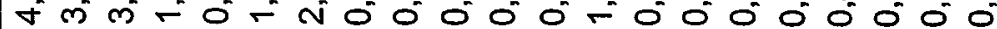

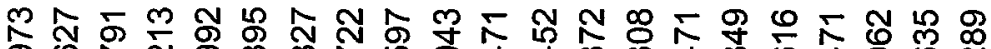

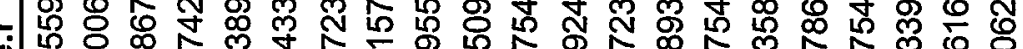

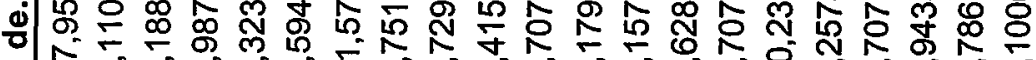

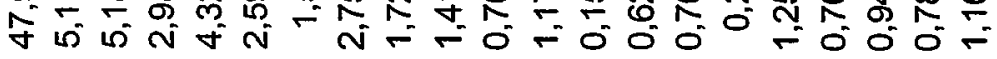

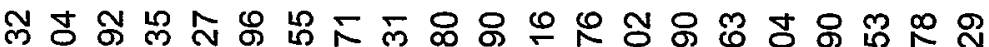
\%

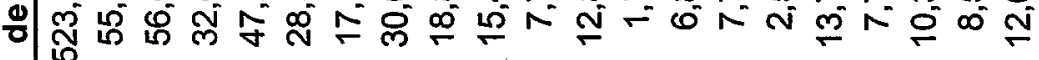
ษั

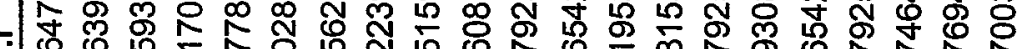

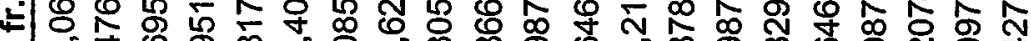

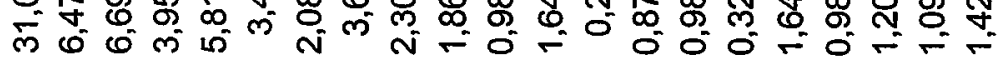
以上ผ \% =

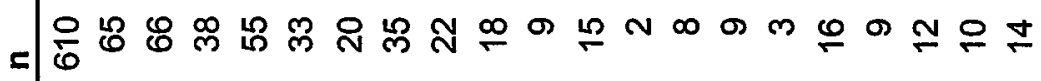

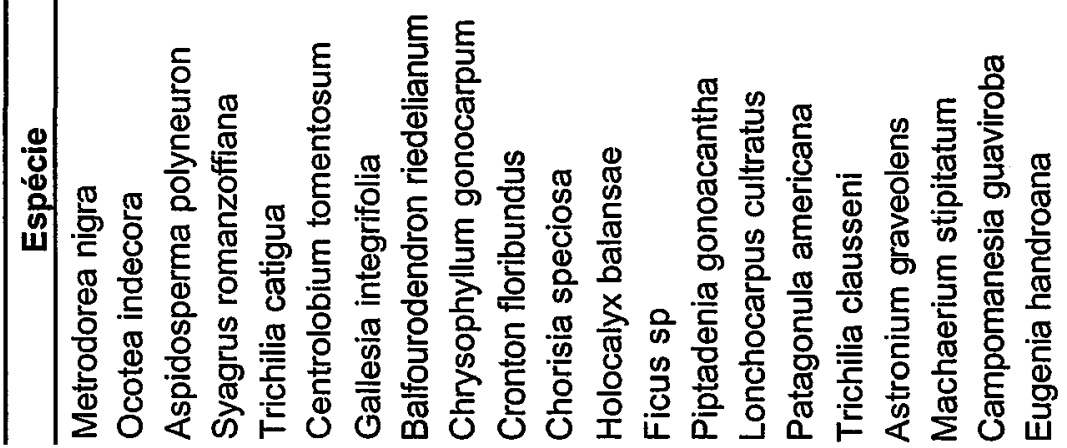




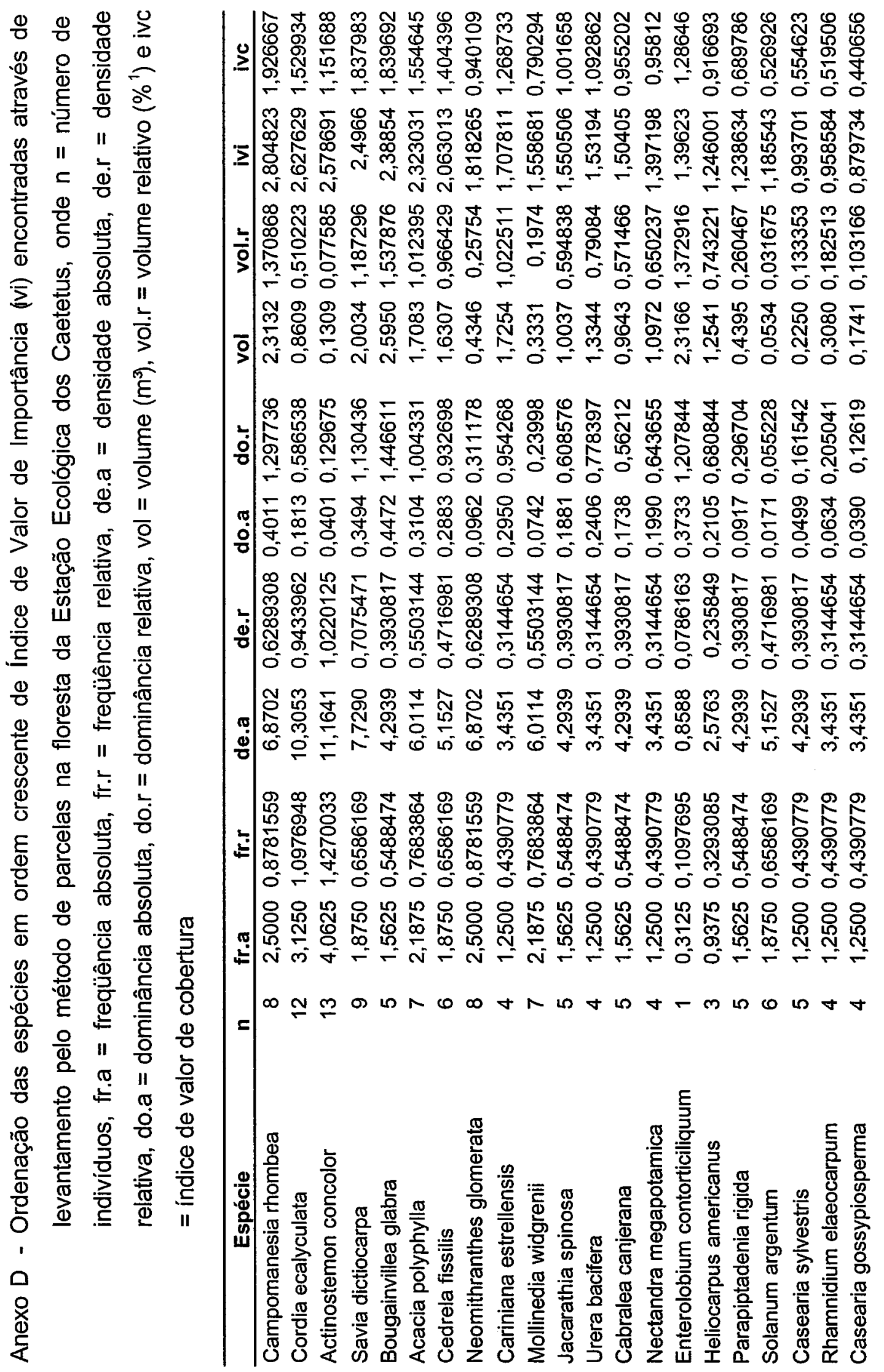




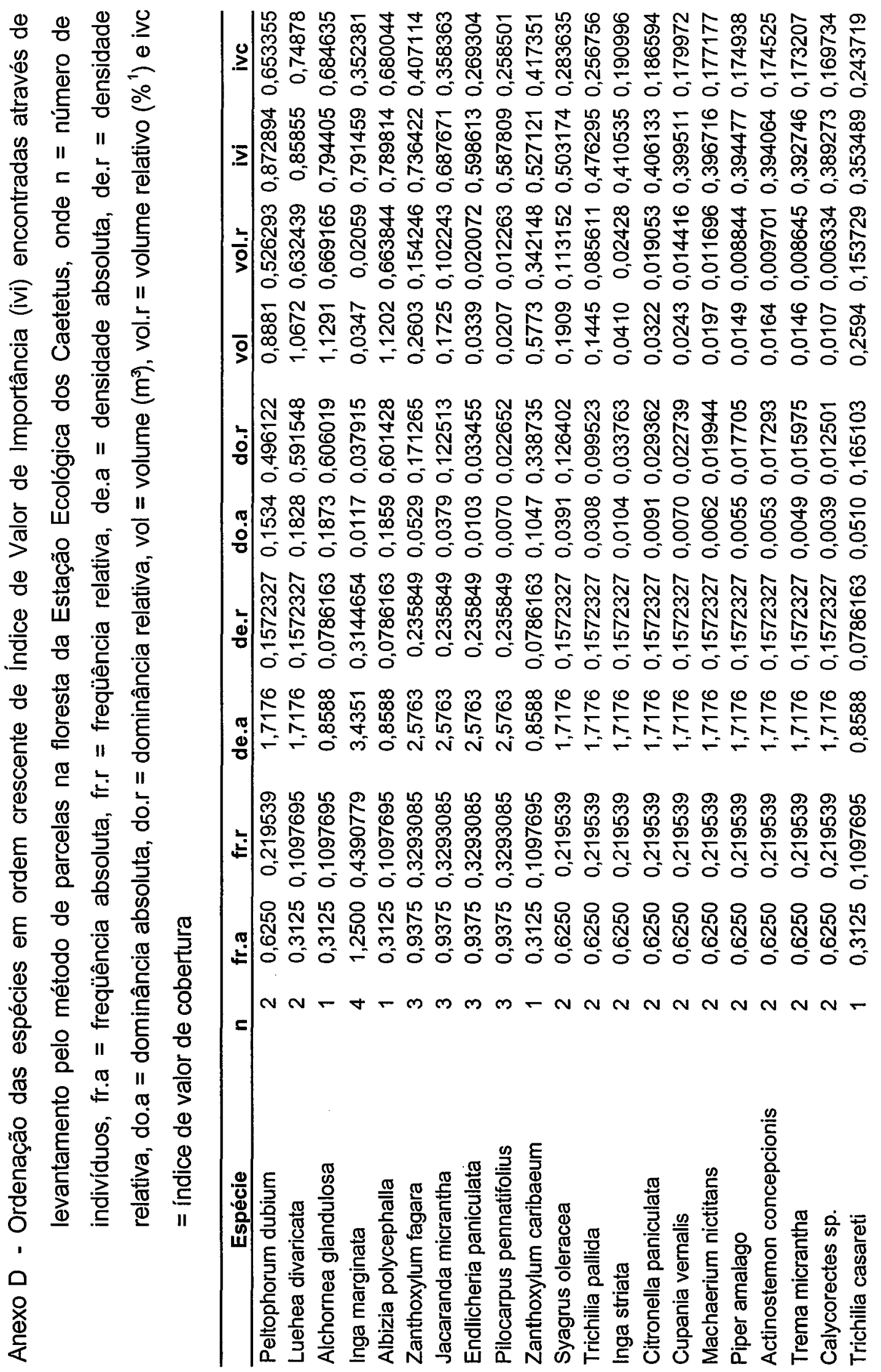




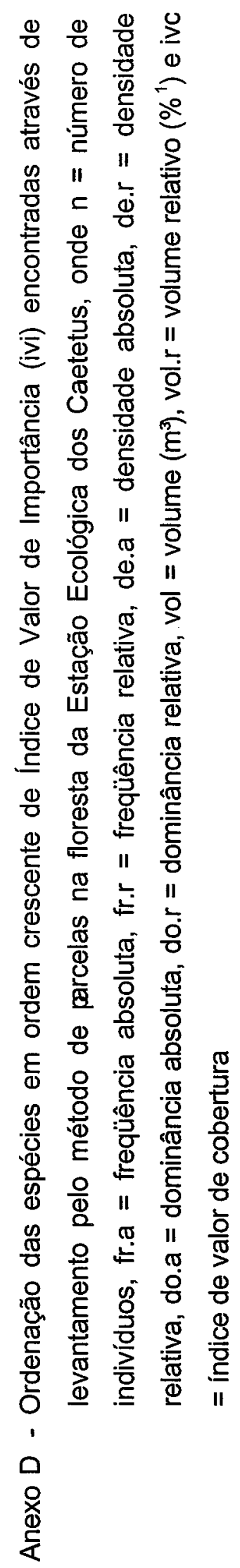

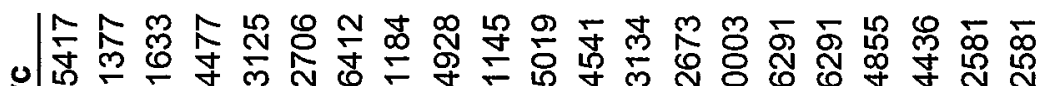

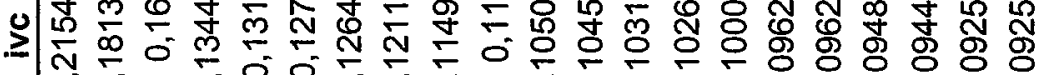

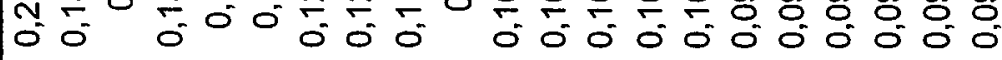

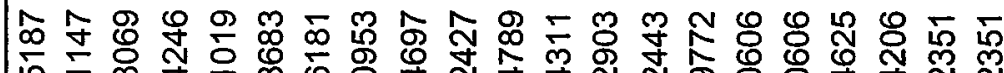

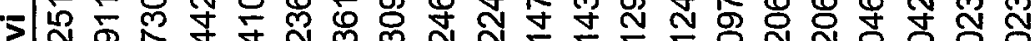
N

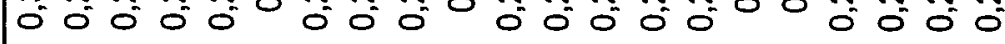

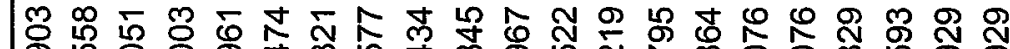

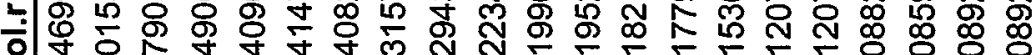

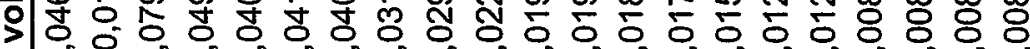

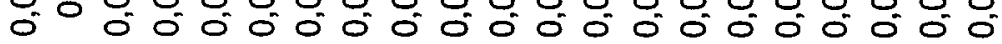

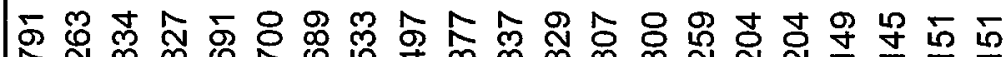

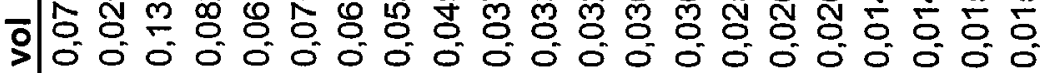

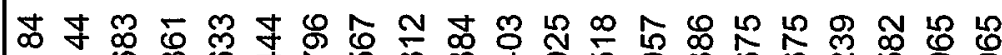

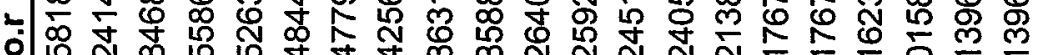

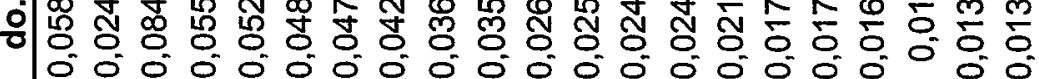

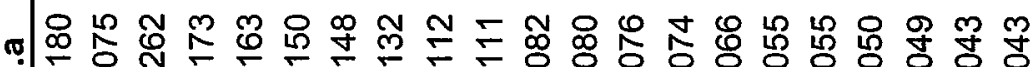

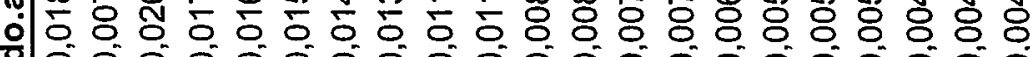

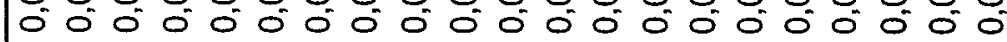

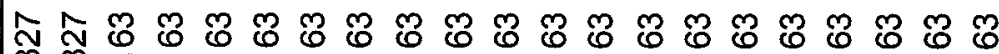
i 인

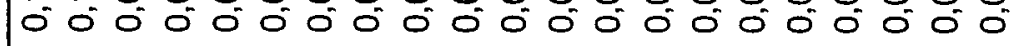
요요

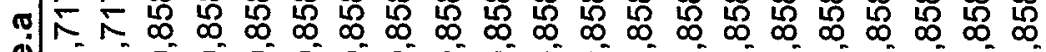
\& = = : 0.

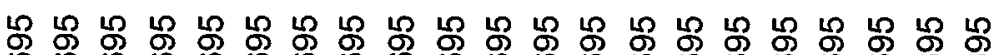
40

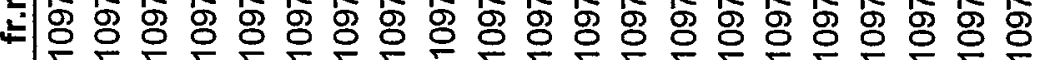

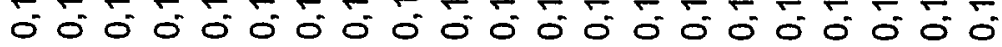

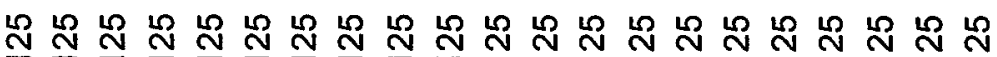

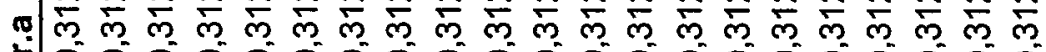

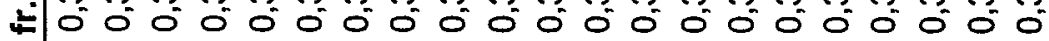

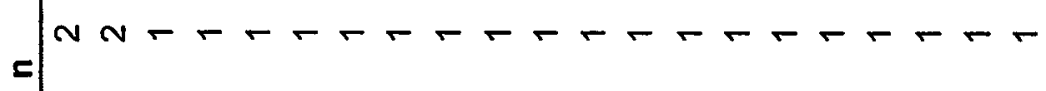

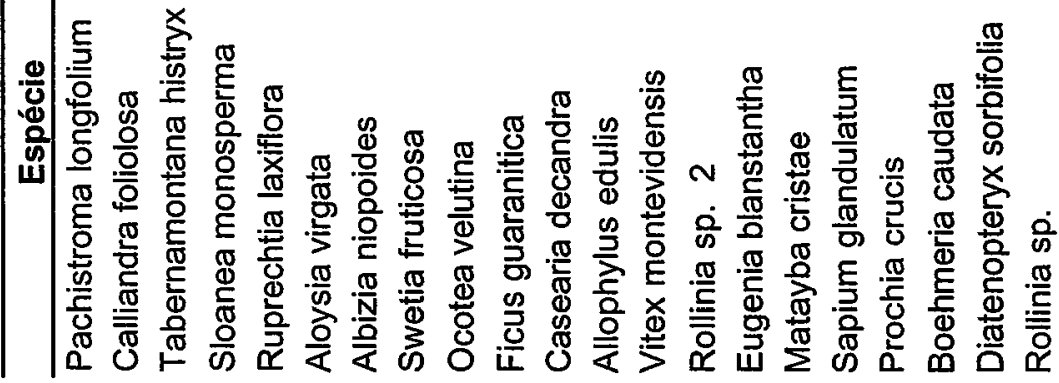




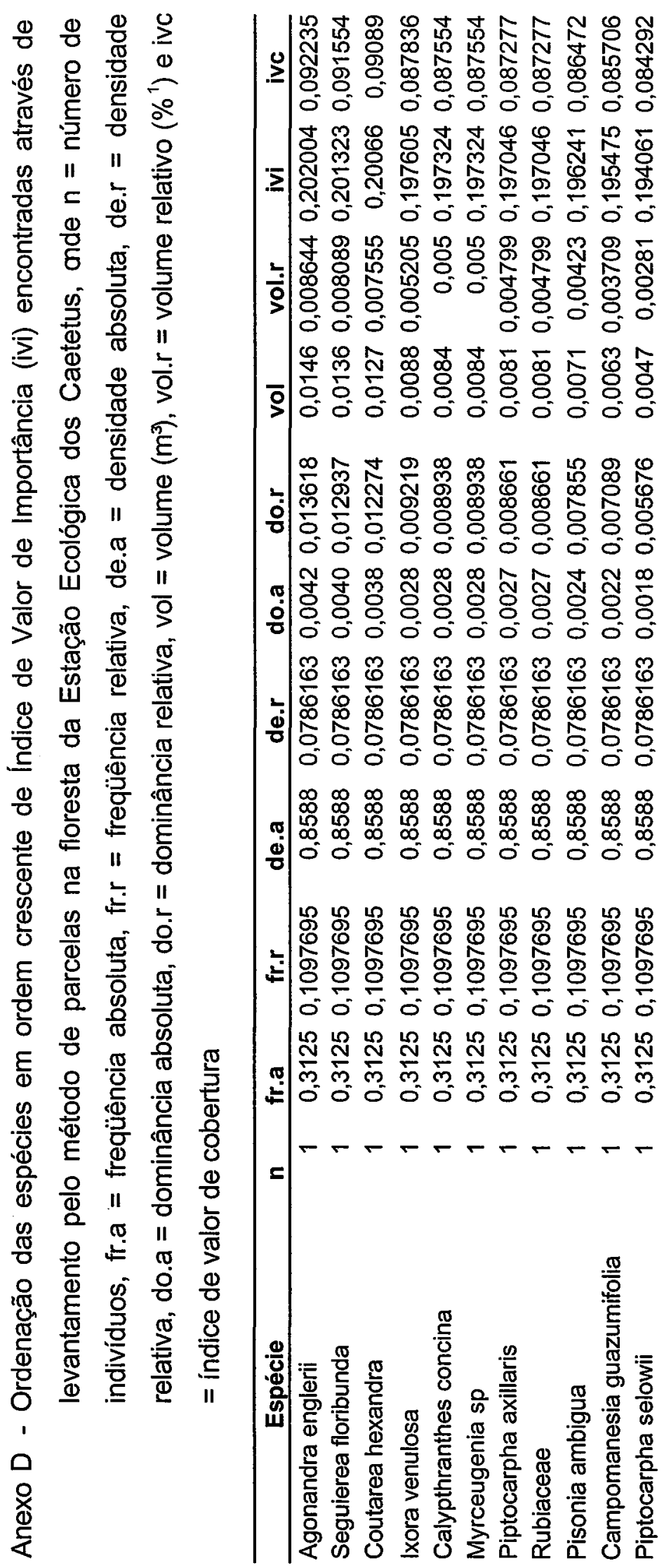




\section{REFERÊNCIAS BIBLIOGRÁFICAS}

AZEVEDO, P. U. E. Indenização de áreas de interesse ambiental: pressupostos e critérios. In: SEMINÁRIO DE DIREITO AMBIENTAL IMOBILIÁRIO. São Paulo, 1995. anais, São Paulo: Centro de Estudos da Procuradoria Geral do Estado de São Paulo, n.6, p.81-87, 1995. (Série Eventos)

BAITELLO, J.B.; AGUIAR, O.T.; ROCHA, F.T. Vegetação: composição e estrutura fitossociológica. In: CURSO INTERNACIONAL DE MANEJO FLORESTAL EM BACIAS HIDROGRÁFICAS, 2. São Paulo: Instituto Florestal, 1997. p.52-68. (Apostila TCTP)

BAITELLO, J.B.; PASTORE, J.A.; AGUIAR, O.T.;SÉRIO, F.C.; SILVA, C.E.F. A vegetação arbórea do Parque Estadual do Morro do Diabo, município de Teodoro Sampaio, Estado de São Paulo. Acta Botânica Brasílica, v.1, n.2, p.221-230, 1988. (supl.).

BAITELLO, J.B.; AGUIAR, O.T.; ROCHA, F.T.; PASTORE, J.A.; ESTEVES, R. Estrutura fitossociológica da vegetação arbórea da Serra da Cantareira (SP) - Núcleo Pinheirinho. Revista do Instituto Florestal, v.5, n.2, p.103-191, 1993.

BARDIN, D. Inventário Florestal, Piracicaba: ESALQ, Depto. Silvicultura, 1974, $27 \mathrm{p}$. 
BATISTA, J.L.F. Levantamentos florestais: conceitos de amostragem aplicados ao levantamento de florestas. Piracicaba: ESALQ, Departamento de Ciências Florestais, 1998. 45p.

BENTES-GAMA, M.M.; SCOLFORO, J.R.S.; GAMA, J.R.V.; OLIVEIRA, A.D. Estrutura e valorização de uma floresta de várzea alta na Amazônia. Cerne, v.8,n.1, p.88-102, 2002.

BRAUN-BLANQUET. V. Fitosociología, bases para el estudio de las comunidades vegetales. Madrid, H. Blume, 1979. 820p.

BRYANT, P.J. Biodiversity and conservation: a hypertext book. http:/bio.uci.edu/ sustain/bio65/lec06, (25 set. 2002)

CAMARGO, J.C.F. Critérios de avaliação. In: SEMINÁRIO DE DIREITO AMBIENTAL IMOBILIÁRIO. São Paulo, 1995 anais, São Paulo: Centro de Estudos da Procuradoria Geral do Estado de São Paulo, 1995 n.6, p.42-62, (Série eventos)

CAMPOS, J.C.C; HEINSDIJK, D. A floresta do Morro do Diabo. Silvicultura em São Paulo, v.7, p.43-58, 1970.

CAVASSAN, O. Florística e fitossociologia da vegetação lenhosa em um hectare de cerrado no Parque Ecológico Municipal de Bauru (SP). Campinas, 1990. 206p. Tese (Doutorado) - Instituto de Biologia, Universidade Estadual de Campinas.

CAVASSAN, O.; CESAR, O.; MARTINS, F.R. Fitossociologia da vegetação arbórea da Reserva Estadual de Bauru, Estado de são Paulo. Revista Brasileira de Botânica, n.7, p.91-106, 1984. 
CAVASSAN, O.; CESAR, O.; MARTINS, F.R. Fitossociologia da vegetação arbórea da Reserva Estadual de Bauru, Estado de São Paulo. Revista Brasileira de Botânica, v.7, n.2, p.91-106, 1997.

CAUSTON, D.R. An introduction to vegetation analysis: principles, pratice and interpretation. London: Unwin Hyman, 1988, 342p.

CESAR, O. Composição florística, fitossociológica e ciclagem de nutrientes em mata mesófila semidecídua (Fazenda Barreiro Rico, município de Anhembi, SP). Rio Claro, 1988. 233p. Tese (Livre-Docência) - Instituto de Biociências. Universidade Estadual Paulista "Júlio de Mesquita Neto".

CHAPMAN, S.B. Methods in plant ecology. New York: John Wiley. 1976, 536p.

COTTAM, G.; CURTIS, J.T. The use of distance measures in phytosociological sampling. Ecology, v.37, n.3, p.451 - 460, 1956.

CRONQUIST, A. An integrated system of classification of flowering plants. New York: Columbia University Press. 1981. 1262p.

CURTIS, J.T.; MCINTOSH, R.P. The interrelation of certain analytic and synthetic phytosociological characters. Ecology, 31, p.434-455, 1956.

DAUBENMIRE, R. Plant communities: a textbook of plant synecology. New York: Harper \& Row Publics, 1968, 368p.

DIAS, A. C. Composição florística, fitossoiológica e diversidade em espécies do componente arbóreo de um trecho de mata secundária, Parque Estadual de Carlos Botelho, SP. Piracicaba, 1993. 120p. Dissertação (Mestrado) - Escola Superior de Agricultura "Luiz de Queiroz", Universidade de São Paulo. 
DIAS, A.C.; NEGREIROS, O.C.; VEIGA, A.A.; COUTO, H.T.Z. Um cotejo entre métodos para levantamento fitossociológico, no Núcleo Sete Barras do Parque Estadual de Carlos Botelho. Boletm Técnico do Instituto Florestal, v.4A, p.463480, 1986. pt.2. (especial)

DIAS, A.C.; TOLEDO FILHO, D.V.; SÉRIO, F.C.; BERTONI, J.E.A.; BAPTISTANOFFS, L.J.; NOFFS, M.S.; PINTO, M.M.; SILVEIRA, M.G.L. Fitossociologia do Parque Estadual da Ilha do Cardoso (SP). In: CONGRESSO NACIONAL DE BOTÂNICA, 37, Ouro Preto (MG), 1989. Resumos. Ouro Preto: SBB, 1989. p.221.

DISLICH, R.; CERSÓSIMO, L.; MANTOVANI, W. Análise da estrutura de fragmentos florestais no Planalto Paulistano - SP. Revista Brasileira de Botânica, v.24, n.3, p.321-332, 2001.

DURIGAN, G.; LEITÃO FILHO, H.F. Florística e fitossociologia de matas ciliares do Oeste Paulista. Revista do Instituto Florestal, v.7, n.2, p.115-265, dez. 1995.

DURIGAN, G.; FRANCO, G. A.D.C.; SAITO, M.; BAITELLO, J.B. Estrutura e diversidade do componente arbóreo da floresta na Estação Ecológica dos Caetetus, Gália, SP. Revista Brasileira de Botânica, v.23, n.4, p.371-383, dez. 2000.

DURIGAN, G.; SANTOS, J.D.; GANDARA, F.B. Fitossociologia de dois fragmentos de floresta estacional semidecidual no Pontal do Paranapanema, SP. Revista do Instituto Florestal, v.14, n.21 p.13-26, 2002.

ESPINDULA, A. Laudo pericial e outros documentos técnicos, 2003. http://www. espindula.com.br, (25 abirl 2003) 
FELICIANO, A.L.P.; ARANGON, L.C.; CAVALHEIRO, F.; SANTOS, J.E.; PIRES, J.S.R. Fitossociologia de um fragmento de floresta estacional semidecidual. Caso de estudo: Estação Experimental de São Carlos, Município de Brotas, SP. In: SIMPÓSIO DE ECOSSISTEMAS BRASILEIROS: CONSERVAÇÃO, 5., Vitória, 2000. ACIESP n.109, v.3, p.300-307, 2000.

FELIPPE, M, S. Aspectos técnico-jurídicos das ações ambientais imobiliárias. In: SEMINÁRIO DE DIREITO AMBIENTAL IMOBILIÁRIO, 2., São Paulo, 1999. anais, São Paulo: Centro de Estudos da Procuradoria Geral do Estado, 2000 n.7, 2000, p.41-45. (série eventos)

FERREIRA, A.B.H. Novo dicionário Aurélio da Língua Portuguesa. Rio de Janeiro: Nova Fronteira, 1986. 1838p.

FIDALGO, O.; BONONI, V.L.R. Técnicas de coleta, preservação e herborização de material botânico. São Paulo: Instituto de Botânica, 1989, 62p.

FIGUEIREDO, N. Estudo fitossociológico em uma floresta mesófila semidecídua secundária na Estação Experimental de Angatuba, município de Angatuba, SP. Campinas, 1993. 160p. Dissertação (M.S.) - Instituto de Biologia, Universidade Estadual de Campinas.

FIGUEIREDO-FILHO, A.; MACHADO, S.A.; ROSOT, N.C. Estimativas volumétricas por unidade de área em florestas naturais. In: CONGRESSO NACIONAL SOBRE ESSÊNCIAS NATIVAS. Campos do Jordão, 1982. anais São Paulo: Silvicultura em São Paulo, 1982. p.491-504. (Ed. Especial) 
FRANCO, G.A.D.C. Florística e Fitossociologia de duas unidades do mosaico florestal da Estação Ecológica dos Caetetus - Floresta Estacional Semidecidual, Gália - SP. Piracicaba, 2002. 95p. Dissertação (Mestrado) - Escola Superior de Agricultura "Luiz de Queiroz", Universidade de São Paulo.

GIBBS, P. E.; LEITÃO-FILHO, H.F. Floristic composition of an área of Gallery Forest near Mogi-Guaçu, State of São Paulo, Brazil. Revista Brasileira de Botânica, v.1, p.151-156, 1978.

GIBBS, P.E.; LEITÃO-FILHO, H.F.; ABBOTT, R.J. Aplication of the point-centred quarter method in a floristic survey of an área of Gallery Forest at Mogi-Guaçu, SP, Brazil. Revista Brasileira de Botânica, v.3, p.17-22, 1980.

GOODLAND, R. A physiognomic analysis of cerrado vegetation of South-Central Brazil. Journal of Ecology, v.59, p.411-419, 1971.

GORENSTEIN, M.R. Métodos de amostragem no levantamento da comunidade arbórea em floresta estacional semidecidual. Piracicaba, 2002. 92p. Dissertação (Mestrado) - Escola Superior de Agricultura “Luiz de Queiroz", Universidade de São Paulo.

HANLEY, N.; SPASH, C.L. Cost-Benefit Analysis and the Environment. Hants, Inglaterra: Edward Elgar, 1993. 278p.

HEINSDJIK, D. Forest inventory in the Amazon Valley. Part 3. Region between Rio Tapajós and Rio Madeira. Roma: FAO, 1958. 17p. (Report, 969.83).

HEINSDJIK, D.C. Inventários florestais na Amazônia. Rio de Janeiro. Ministério da Agricultura. Setor de Inventários Florestais, 1963. 100p. (Boletim, 6)

HEINSDJIK, D.C.; CAMPOS, J.C.C. Programa de manejo das florestas de produção estaduais. Silvicultura em São Paulo, v.6, p.365-405, 1967. 
HIGUCHI, N.; SANTOS, J. dos.; JARDIM, F.C.S. Tamanho de parcela amostral para inventário florestal. Acta Amazônica, v.12, n.1, p.91-103, 1982.

INSTITUTO BRASILEIRO DE DESENVOLVIMENTO FLORESTAL Inventário Florestal Nacional (Síntese do Resultados). Brasília, 1983. 37p.

FUNDAÇÃO INSTITUTO BRASILEIRO DE GEOGRAFIA E ESTATÍSTICA Manual técnico da vegetação brasileira. Departamento de Recursos Naturais e Estudos Ambientais. - Rio de Janeiro: IBGE, 1992. 92p.

IMAÑA-ENCINAS, J. Inventário florestal por faixas de amostragem. Pesquisa Agropecuária Brasileira, v.26, n.I, p.25-30, 1991.

INSTITUTO DE PESQUISAS TECNOLÓGICAS. Mapa geomorfológico do Estado de São Paulo. Monografias, n.5, p.1-126, 1981. (Escala 1:1.000.000).

IVANAUSKAS, N.M.; RODRIGUES, R.R. Florística e fitossociologia de remanescentes de floresta estacional decidual em Piracicaba, São Paulo. Brasil. Revista Brasileira de Botânica, v.23,n.3, p.291-304, 2000.

IVANAUSKAS, N.M; RODRIGUES, R.R.; NAVE, A.G. Fitossociologia de um trecho de floresta estacional semidecidual em Itatinga, São Paulo, Brasil. Scientia Florestalis, n.56, p.83-99, 1999.

JANCOWSKY, I.P.; BATISTA, J.L.F. Desapropriação direta e indireta: cobertura vegetal e inventario florestal. / Apresentado no Seminário “Agrimensura Total", APEAESP, Mirandópolis:, 1998/ 
JORGE, L.A.B. Equações de volume comercial com casca em floresta tropical pluvial no norte do Espírito Santo. In: CONGRESSO NACIONAL SOBRE ESSÊNCIAS NATIVAS. Campos do Jordão, 1982 anais, São Paulo: Silvicultura em São Paulo, 1982. p.456-467. (Ed. Especial)

KREBS, C.J. Ecological Methology (2. ed.) Menlo Park: Addison Wesley Longman, 1999. 620p.

KRONKA, F. N.; MATSUKUMA, C.K.; NALON, M.A.; DEL CALI, I.H.; ROSSI, M.; MATTOS, I.F.A; SHIN-IKE, M.S.; PONTINHA, A.A.S. Inventário florestal do Estado de São Paulo. São Paulo: Instituto Florestal; Secretaria do Meio Ambiente, 1993. 199p.

KURTZ, B.C.; ARAUUJO, D.S.D. de. Composição florística e estrutura do componente arbóreo de um trecho de mata atlântica na Estação Ecológica Estadual do Paraíso, Cachoeira de Macacu, Rio de Janeiro, Brasil. Rodriguesia, v.51, p.69-112, 2000.

LAMAC, J. Provas nas ações de desapropriação ambiental. In: AQUINO, M.; AZEVEDO, P.U.E (Org.). Regularização imobiliária de áreas protegidas. São Paulo: Centro de Estudos da Procuradoria Geral do Estado, , 1999. v2, p.55-62. (Doutrina e Jurisprudência)

LEITÃO-FILHO, H.F. Aspectos taxonômicos das florestas do Estado de São Paulo. Silvicultura em São Paulo v.6A, p.197-206, 1982.

LEITÃO-FILHO, H.F. A flora arbórea da Serra do Japi. In: MORELLATO, P.P. (org.). História natural da Serra do Japi - ecologia e preservação de uma área florestal no sudeste do Brasil. Campinas: EDUNICAMP, 1992. p.40-62. 
MACHADO, S.A.; ROSOT, N.C.; FIGUEIREDO, A.F. Distribuição diamétrica em uma floresta tropical úmida da Amazônia brasileira. In: CONGRESSO NACIONAL SOBRE ESSÊNCIAS NATIVAS. Campos do Jordão, 1982. anais, São Paulo: Silvicultura em São Paulo, 1982. p.399-406. Ed. especial.

MAGALHÃES, J. P. Política e legislação florestal. In. CONGRESSO FLORESTAL BRASILEIRO, 6, Campos do Jordão, 1990. Anais. São Paulo: SSB, 1990. v.1, p.5152.

MAIA, A. G. Valoração de Recursos Ambientais. Campinas, 2002, 183p. Dissertação (M.S) - Instituto de Economia, Universidade Estadual de Campinas.

MANTOVANI, W. Estrutura e dinânica da floresta atlântica na Juréia, Iguape - SP. São Paulo, 1993. 126p. Tese (Livre- Docência) - Instituto de Biociências, Universidade de São Paulo.

MARGUTTI, A.; STELLA, A.; VOLVODIC, M.A.; KAGEYAMA, P.Y.; BATISTA, J.L.F. Inventário florestal de cinco espécies nativas da floresta estacional semidecidual visando estudo de conservação genética. In: SIMPÓSIO INTERNACIONAL DE INICIAÇÃO CIENTÍFICA DA UNIVERSIDADE DE SÃO PAULO, 8., Piracicaba, 1998. Resumos. Piracicaba: ESALQ, 1998. p. 110.

MARQUES, J.F.; COMUNE, A. Quanto vale o ambiente: interpretações sobre o valor econômico ambiental. In: ENCONTRO NACIONAL DE ECONOMIA, 23, Salvador, 1995. Anais. Salvador; 1995. p.633-651.

MARTINEZ-RAMOS, M. Claros, ciclo vitales de los arboles tropicales y regeneración natural de las selvas altas perennifoliadas. In: GOMEZ-POMPA, A. (Ed.), Investigaciones sobre la regeneración de selvas altas em Veracruz, México. México: Editorial Alhambra Mexicana, 1985. v.2., p.191-239. 
MARTINS, F.R. Critérios para avaliação de recursos vegetais In: SIMPÓSIO SOBRE A COMUNIDADE VEGETAL COMO UNIDADE BIOLÓGICA, TURÍSTICA E ECONÔMICA, São Paulo, 1978. Anais. São Paulo: ACIESP, 1978. p.136-149.

MARTINS, F.R. O método de quadrantes e a fitossociologia de uma floresta residual do interior do Estado de São Paulo. São Paulo, 1979. 239p. Tese (Doutorado) Instituto de Biociências, Universidade de São Paulo.

MARTINS, F.R. Fitossociologia de florestas do Brasil: Um histórico bibliográfico. Pesquisas, v.40, p.103-164, 1989. (Série Botânica).

MARTINS, F.R. Estrutura de uma floresta mesófila. 2. ed. Campinas: UNICAMP 1993, 246 p. (Série Teses)

MARTINS, F.R.; SANTOS, F.A.M. Técnicas usuais de estimativa da biodiversidade. Revista Holos, v.1, p. 236-267, 1999.

MATEUCCI, S.; COLMA, A. Metodologia para el estúdio de la vegetación. Secretaría General Organización de los Estados Americanos. Programa Regional de Desarrollo Científico y Tecnológico. Washington, DC. 1982,.168p.

MATTOS, I. F. A.; ROSSI, M.; SILVA, D. A.; PFEIFFER, R. M. Levantamento do meio biofísico e avaliação da fragilidade do ecossistema na Estação Ecológica do Caetetus, SP. Sociedade e Natureza, v.15, p.388-393, 1996.

MELLO, J.M.; OLIVEIRA-FILHO, A.T.; SCOLFORO, J.R.S. Comparação entre procedimentos de amostragem para avaliação estrutural de um remanescente de floresta estacional semidecidual Montana. Revista Cerne, v.2, n.2, p.1-15, 1996. 
MINISTÉRIO DO MEIO AMBIENTE/SECRETARIA DE BIODIVERSIDADE E FLORESTAS. Avaliação e ações prioritárias para a conservação da biodiversidade da Mata Atlântica e Campos Sulinos. Brasília: Mma/SBF, 2000. $40 \mathrm{p}$.

MORELLATO, L.P.C. The Brazilian Atlantic Forest. Biotropica, v.32, n.4b, p.786$792,2000$.

MOSCOVICH, F.A.; BRENA, D.A.; LONGHI, S.J. Comparação de diferentes métodos de amostragem, de área fixa e variável, em uma floresta de Araucária angustifólia. Ciência Florestal, v.9, n.1, p.173-191, 1999.

MUELLER-DOMBOIS, D.; ELLENBERG, H. Aims and methods of vegetation ecology. New York: John Willey, 1974. 545p.

NASCIMENTO, H.E.M.; DIAS, A. da S.; TABANEZ, A.A.J.; VIANA, V.M. Estrutura e dinâmica de populações arbóreas de um fragmento de floresta estacional semidecidual na região de Piracicaba, SP. Revista Brasileira de Biologia, v.59, n.2, p.329-342, 2002.

NETO, S.P.; BRENA, D.A. Inventário Florestal. v.1, 1997. 316p.

NOGUEIRA, J.M.; MEDEIROS, M.A.A.; ARRUDA, F.S.T. Valoração econômica do meio ambiente: ciência ou empirismo ?. Cadernos de Ciência \& Tecnologia, v.17, n.2, p.81-115, 2000.

OLIVEIRA-FILHO, A.T.; ALMEIDA, R.J.; MELLO,J.M. \& GAVILANES, M.L. Estrutura fitossociológica e variáveis ambientais em um trecho da mata ciliar do córrego dos Vilas Boas, Reserva Biológica do Poço Bonito, Lavras (MG). Revista brasileira de Botânica, v.17, p.76-85, 1994. 
PAGANO, S.N.; LEITÃO-FILHO, H.F.; SHEPHERD, G.J. Estudo fitossociológico em mata mesófila semidecídua no município de Rio claro (Estado de São Paulo). Revista brasileira de Botânica, v.10, p.49-61, 1987.

PAIVA, Y.C.E. A justa indenização e a coisa julgada. In: Regularização imobiliária de áreas protegidas. In: AQUINO, M.; AZEVEDO, P.U.E. (Org.), São Paulo: Centro de Estudos da Procuradoria Geral do Estado, 1999. v.2, p. 103-110 (Coletânea de doutrina e jurisprudência)

PAULA, J.E.; IMAÑA-ENCINAS, J.; PEREIRA, B. A.S. Parâmetros volumétricos e da biomassa da mata ripária do Córrego do Macacos. Revista Cerne, v.2, n.2, p.91$105,1996$.

PEDREIRA, L.O.L. Métodos de avaliação de benefícios indiretos de floresta: uma revisão. In. CONGRESSO FLORESTAL BRASILEIRO, 6, Campos do Jordão, 1990. Anais. São Paulo: SSB, 1990. v.3, p.23-29.

PEIXOTO, A.L.; GENTRY. A. Diversidade e composição florística da mata de tabuleiro na Reserva Florestal de Linhares (Espírito Santo, Brasil). Revista brasileira de Botânica, n.13, p.19-25, 1990.

PELLEGRINO, J. C. A propósito do valor potencial: raizes, problemas e implicações. Revista dos Tribunais, v.571, 2, p.275-288, 1972.

PIMENTEL GOMES, F. Curso de Estatística Experimental. 12.ed. Piracicaba: Nobel, EDUSP, 1987, 467p.

POLLARD, J.H. On distance estimator of density in randomly distributed forests. Biometrics, v.27, p.991-1002, 1971. 
REIS, I.A.; ASSUNÇÃO, R.M. Comparando três métodos de amostragem: métodos de distâncias, contagem de quadrats e conglomerado adaptativo. Scientia Florestalis, n.54, p.119-130, 1998.

RICKLEFS, R. E. A economia da Natureza. 3.ed. Rio de Janeiro: Guanabara/Koogan Ed, 1993. 470p.

RIZZINI, C.T. Tratado de Fitogeografia do Brasil: aspectos ecológicos. São Paulo: EUCITEC, Ed. da Universidade de São Paulo, v.1, 1976. 327p.

ROCHA, F.T; LOPES, G.A.C.; SPEGIORIN, L.; YOKOMIZO, N.K.S.; MONTAGNA, R.G.; FLORSHEIM, S.M.B. Durabilidade natural de madeiras em contato com o solo - V: Avaliação final (20 anos). Revista do Instituto Florestal v.12, n.1, p.59-66, 2000.

RODRIGUES, R.R. Métodos fitossociológicos mais usados. Casa da Agricultura, v.10, n.1, p.20-24, 1988.

RODRIGUES, R.R. Análise estrutural de formações florestais ripárias. In: SIMPÓSIO SOBRE MATA CILIAR, 1., Campinas, 1989. Anais. Rio de Janeiro: Fundação Cargil, 1989. p.99-119.

RODRIGUES, R.R. Análise de um remanescente de vegetação natural às margens do rio Passa Cinco, Ipeúna, SP. Campinas, 1992. 352p. Tese (Doutorado) Universidade Estadual de Campinas.

ROLLET, J.P.; QUEIROZ, W.T. Observações e contribuições aos inventários florestais na Amazônia. In: CONGRESSO FLORESTAL BRASILEIRO, 2., Manaus 1978. Anais. São Paulo: Sociedade Brasileira de Silvicultura, 1978. v.2, p.405-408. 
SCOLFORO, J.R.; MELLO,J.M.; LIMA, C.S.A. Obtenção de relações quantitativas para estimativa de volume do fuste em floresta estacional semidecidual montana. Revista Cerne, v.1, n.1, p.123-134, 1994.

SEBER, G.A.F. The estimation of animal abundance. Londres: Charles Griffin, 1982. 1v.

SHWENCK JR. P. M.; AZEVEDO, P. U. E. Regularização imobiliária de áreas protegidas. Secretaria de Estado do Meio Ambiente. São Paulo: Procuradoria Geral do Estado, 1998, v1 - (Coletânea de trabalhos forenses, relatórios técnicos e jurisprudência) 240p.

SHWENCK JR. P.M. Exploração econômica de florestas nativas. In: SEMINÁRIO DE DIREITO AMBIENTAL IMOBILIÁRIO, 2., São Paulo, 1999. anais, São Paulo: Centro de Estudos da Procuradoria Geral do Estado, 2000. n.7, p.87-104. (série eventos)

SILVA, D.W.; SOARES, J.J. Estrutura etária das pricipais populações arbóreas em um área de cerradão na Fazenda Canchim, São Carlos, SP. Revista Ciências Exatas e Naturais, v.1, n.1, p.58-66, 1999.

SILVA, A. da S.; SOARES, J.J. Levantamento fitossociológico em um fragmento de floresta estacional semidecídua, no município de São Carlos, SP. Acta Botânica. Brasílica, v.16, n.2, p.205-216, 2002.

SILVA, J.N.M.; LOPES, J.C.A. Distribuição espacial de árvores na Floresta Nacional do Tapajós. Circular técnica, EMBRAPA - CPATU, n.26, 1982. 1v. 
SILVA JÚNIOR, M.C. da; FELFILI, J.M.; ROSA, C.A. Comparação dos métodos de parcelas e quadrantes na estimativa de alguns parâmetros da vegetação do cerrado (s.s.) na Fazenda Água Limpa (FAL) - Brasilia - DF. In: CONGRESSO DA SOCIEDADE BOTÂNICA DE SÃO PAULO, 4., Campinas, 1978. Resumos. Campinas: UNICAMP, 1978. p.85.

SCHLITTER, F.H.M. Fitossociologia e ciclagem de nutrientes na floresta tropical do Parque Estadual do Morro do Diabo (Régio do Pontal do Paranapanema, Estado de São Paulo). Rio Claro, 1990. 279p. Tese (Doutorado) - Instituto de Biociências, Universidade Estadual Paulista "Julio de Mesquita Filho".

SCHLITTER, F,H,M; MARTINS, G.; CESAR, O. Estudos fitossociológicos na Floresta do Morro do Diabo (Pontal do Paranapanema, SP, Brasil). Arquivos de Biologia e Tecnologia, v.38, n.1, p.217-234, 1995.

STELLA, A.; SILVEIRA FILHO, F.R.X.; MOSTER, C.; BATISTA, J.L.F. Inventário de Euterpe edulis na Reserva Ecológica de Caetetus. In: SIMPÓSIO INTERNACIONAL DE INICIAÇÃO CIENTÍFICA DA UNIVERSIDADE DE SÃO PAULO, 8., Piracicaba, 1998. Resumos. Piracicaba: ESALQ, 1998. p. 113.

STUCCHI, G.B. Instrumentos jurídicos de atuação do poder público em matéria ambiental: A questão da atuação da Procuradoria Geral do Estado. In: SEMINÁRIO DE DIREITO AMBIENTAL IMOBILIÁRIO. São Paulo, 1995, anais. Centro de Estudos da Procuradoria Geral do Estado de São Paulo, 1995, n.6, p.101-105. (série eventos)

TABANEZ, M.F. Plano de Manejo da Estação Ecológica dos Caetetus ( no prelo). 
TABANEZ, A.A.J. Ecologia e manejo de ecounidades em fragmento de floresta estacional semidecidual na região de Piracicaba, SP. Piracicaba, 1997. 85p. Dissertação (Mestrado) - Escola Superior de Agricultura "Luiz de Queiroz", Universidade de São Paulo.

VIANA, V.M.; TABANEZ, A.A.J. Biology and conservation of Forest fragments in the brazilian atlantic moist Forest. In: SCHELLAS, J.; GREENBERG, R. (ed.). ,Forest patches in tropical landscapes. Washington D.C.: Island Press, 1996. p.151-167.

VIEIRA, M.G.L.; MORAE, J.L.; BERTONI, J.E.A.; MARTINS, F.R.; ZANDARIN, M.A. Composição florística e estrutura fitossociológica da vegetação arbórea do Parque Estadual da Vassununga, Santa Rita do Passa Quatro (SP). II - Gleba Capetinga Oeste. Revista do Instituto Flotestal, v.1, n.1, p.135-159, 1989.

VICTOR, M.A.M. A devastação florestal. São Paulo: Sociedade Brasileira de Silvicultura, 1975. 49p.

VUOLO, J.H. Fundamento da Teoria de Erros. São Paulo:Edgard Blucher, 1998. 249 p.

WERNECK, M.S.; PEDRALLI, G.; KOENIG, R.; GISEKE, L.F. Florística e estrutura de três trechos de uma floresta semidecídua na Estação Ecológica do Tripuí, Ouro Preto, MG. Revista Brasileira Botânica, v.23, n.1, p.97-106, 2000. 